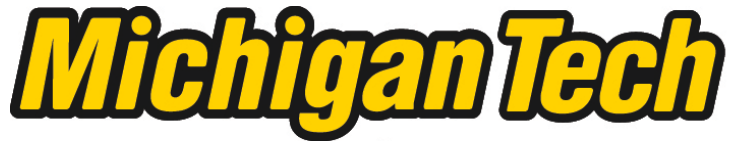 \\ Michigan Technological University Create the Future Digital Commons @ Michigan Tech
}

2013

Characterization Of Porous Media In Proton Exchange Membrane Fuel Cell Based on Percolation Studies

Stephen Stacy

Follow this and additional works at: https://digitalcommons.mtu.edu/etds

Part of the Mechanical Engineering Commons

Copyright 2013 Stephen Stacy

\section{Recommended Citation}

Stacy, Stephen, "Characterization Of Porous Media In Proton Exchange Membrane Fuel Cell Based on Percolation Studies", Master's Thesis, Michigan Technological University, 2013.

https://doi.org/10.37099/mtu.dc.etds/639

Follow this and additional works at: https://digitalcommons.mtu.edu/etds

Part of the Mechanical Engineering Commons 


\title{
CHARACTERIZATION OF POROUS MEDIA IN PROTON EXCHANGE MEMBRANE FUEL CELL BASED ON PERCOLATION STUDIES
}

\author{
By \\ Stephen Stacy \\ A THESIS \\ Submitted in partial fulfillment of the requirements for the degree of \\ MASTER OF SCIENCE \\ In Mechanical Engineering \\ MICHIGAN TECHNOLOGICAL UNIVERSITY \\ 2013
}

Copyright (C) 2013 Stephen Stacy 
This thesis is has been approved in partial fulfillment of the requirements for the Degree of MASTER OF SCIENCE in Mechanical Engineering.

$$
\text { Department of Mechanical Engineering - Engineering Mechanics }
$$

Dissertation Advisor: Dr. Jeffrey S. Allen

Committee Member: $\quad$ Dr. Kazuya Tajiri

Committee Member: Dr. Wenzhen Li

Department Chair: Professor William W. Predebon 


\section{CONTENTS}

Table of Contents . . . . . . . . . . . . . . . . . . . iii

List of Figures . . . . . . . . . . . . . . . . . . . . . . . . . . . . . iv

List of Tables . . . . . . . . . . . . . . . . . . . . . . . viii

Acknowledgments . . . . . . . . . . . . . . . . . . .

Abstract ................................. xi

1. Introduction . . . . . . . . . . . . . . . . . . . 1

1.1 PTL Motivation . . . . . . . . . . . . . . . . . . . . . . . . . . . . . . . . . . . .

1.2 CL Motivation . . . . . . . . . . . . . . . . . . . . . . . . . . . 3

2. Drainage vs. Imbibition . . . . . . . . . . . . . . . . . 4

3. Experimental Setup . . . . . . . . . . . . . . . . . . . . . . . . 7

3.1 Porous Transport Layer Experiment. . . . . . . . . . . . . . . . . . . 7

3.2 Catalyst Layer Experimental Setup . . . . . . . . . . . . . . . . . . . 8

4. PTL Characterization . . . . . . . . . . . . . . . . . . . 14

5. Catalyst Layer Characterization . . . . . . . . . . . . . . . . . . . . . . . . 23

5.1 Process 1 and Process 2 Results . . . . . . . . . . . . . . . . . . 23

5.2 Full CCM Results . . . . . . . . . . . . . . . . . . . . . . 27

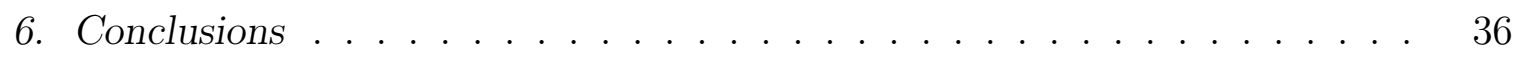

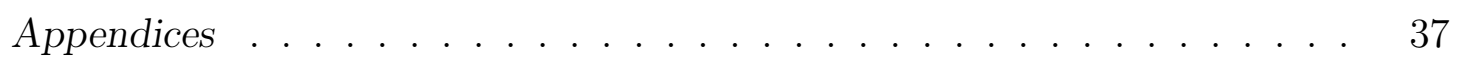

A. Nomenclature . . . . . . . . . . . . . . . . . . . . . . 39

B. PTL Percolation Pressure Plots . . . . . . . . . . . . . . . . . . . . . . . . 40 
C. PTL Area Plots . . . . . . . . . . . . . . . . . . . . . . . . . 49

D. PTL Ce Plots . . . . . . . . . . . . . . . . . . . . 58

E. Process 1 and Process 2 Catalyst Layer Pressure Plots . . . . . . . . 67

F. Full CCM Percolation Pressure Plots . . . . . . . . . . . . . . . . . 74

G. Full CCM Percolation Pressures . . . . . . . . . . . . . . . . . . . 105

H. Full CCM Percolation Testing Summary . . . . . . . . . . . . . . . 115

I. Full CCM Pressure vs Wetted Volume . . . . . . . . . . . . . . . . 126

J. Full CCM Permeability Plots . . . . . . . . . . . . . . . . . . . 157 


\section{List OF Figures}

1.1 PEM Fuel Cell . . . . . . . . . . . . . . . . . . . . . . . . . . . . . . 2

2.1 Phase diagrams for two-phase flow in porous media.[10] $\ldots \ldots$. . 6

3.1 PTL experimental setup schematic $\ldots \ldots \ldots \ldots$

3.2 PTL experimental setup $\ldots \ldots \ldots \ldots \ldots$

3.3 Process 1 and Process 2 SEM images . . . . . . . . . . . . . . . 10

3.4 Catalyst layer experimental setup schematic . . . . . . . . . . . . 11

$3.5 \quad$ Catalyst Layer experimental setup. . . . . . . . . . . . . . . . 13

4.1 Capillary Fingering in the Cathode Nonrun Substrate PTL. . . . . . 15

4.2 Stable Displacement in the Cathode Nonrun PTL with MPL. . . . . . 16

4.3 Percolation Pressures for the Anode PTL of aged MEA . . . . . . . . 17

4.4 Ce plot for the Anode PTL that has been conditioned . . . . . . . . . 19

4.5 Ce comparison for Non-Run with and without MPL . . . . . . . . 20

4.6 Ce comparison for Cathode Non-Run, Conditioned, and Aged with MPL 21

4.7 Ce comparison for Anode Non-Run, Conditioned, and Aged with MPL 22

5.1 Percolation in Process 1 of catalyst layers. . . . . . . . . . . . . 24

5.2 Percolation pressure for Process 1 CL $\ldots \ldots \ldots \ldots \ldots \ldots$

5.3 Percolation pressure for Process $2 \mathrm{CL} \ldots \ldots \ldots \ldots \ldots$

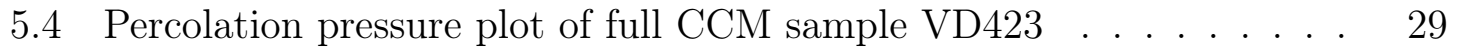

5.5 Summary of percolation pressure growth rate for nonrun CCMs . . . 31

$5.6 \quad$ Summary of the percolation pressure growth rate for conditioned and

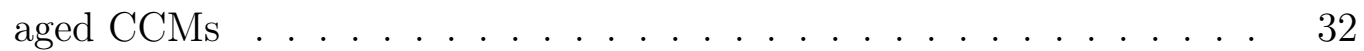

5.7 Percolation pressure vs Wetted volume plot of nonrun full CCMs. . . 34

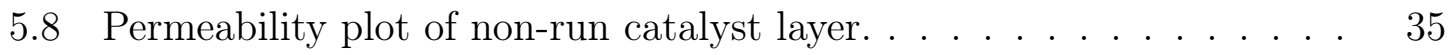

B.1 Percolation Pressures for the Cathode Non-Run Substrate . . . . . . 41

B.2 Percolation Pressures for the Cathode Non-Run Substrate sample 1 . 42

B.3 Percolation Pressures for the Anode Non-Run PTL sample 1 . . . . . 43

B.4 Percolation Pressures for the Cathode Non-Run PTL sample 2 . . . . 44 
B.5 Percolation Pressures for the Cathode Condtioned PTL . . . . . . . . 45

B.6 Percolation Pressures for the Anode Condtioned PTL . . . . . . . . . 46

B.7 Percolation Pressures for the Cathode Aged PTL . . . . . . . . . . . 47

B.8 $\quad$ Percolation Pressures for the Anode Aged PTL . . . . . . . . . . . . 48

C.1 Area growth rate for Cathode Substrate Nonrun . . . . . . . . . . . . 50

C.2 Area growth rate forCathode Nonrun Sample 1 . . . . . . . . . . . . 51

C.3 Area growth rate forCathode PTL Nonrun Sample 2 . . . . . . . . . 52

C.4 Area growth rate for Anode PTL Nonrun . . . . . . . . . . . . . . . . 53

C.5 Area growth rate for Cathode PTL Conditioned . . . . . . . . . . . . 54

C.6 Area growth rate for Anode PTL Conditioned . . . . . . . . . . . . . 55

C.7 Area growth rate for Cathode PTL Aged . . . . . . . . . . . . . . . . 56

C.8 Area growth rate for Anode PTL Aged . . . . . . . . . . . . . . . . . 57

D.1 Ce data for Cathode Substrate Nonrun . . . . . . . . . . . . . . . . . 59

D.2 Ce data for Cathode PTL Nonrun Sample 1 . . . . . . . . . . . . . . 60

D.3 Ce data for Cathode PTL Nonrun Sample 2 . . . . . . . . . . . . . . 61

D.4 Ce data for Anode PTL Nonrun . . . . . . . . . . . . . . . . . . . . 62

D.5 Ce data for Cathode PTL Conditioned . . . . . . . . . . . . . . . . . 63

D.6 Ce data for Anode PTL Conditioned . . . . . . . . . . . . . . . . . . 64

D.7 Ce data for Cathode PTL Aged . . . . . . . . . . . . . . . . . . . . . 65

D.8 Ce data for Cathode PTL Conditioned . . . . . . . . . . . . . . . . . 66

E.1 $\quad$ Percolation pressure for Process 1 at $9.48 \mathrm{E}-4 \mathrm{mLs}^{-1}$. . . . . . . . . . 68

E.2 Percolation pressure for Process 1 at $18.75 \mathrm{E}-4 \mathrm{mLs}^{-1}$. . . . . . . . . . 69

E.3 Percolation pressure for Process 1 at $37.08 \mathrm{E}-4 \mathrm{mLs}^{-1}$. . . . . . . . . . 70

E.4 Percolation pressure for Process 2 at $9.48 \mathrm{E}-4 \mathrm{mLs}^{-1}$. . . . . . . . . . 71

E.5 Percolation pressure for Process 2 at $18.75 \mathrm{E}-4 \mathrm{mLs}^{-1}$. . . . . . . . . . 72

E.6 $\quad$ Percolation pressure for Process 2 at $37.08 \mathrm{E}-4 \mathrm{mLs}^{-1}$. . . . . . . . . . 73

F.1 $\quad$ Percolation pressure for VD420 at 9.48E-4 $\mathrm{mLs}^{-1}$. . . . . . . . . . . . 75

F.2 $\quad$ Percolation pressure for VD420 at $18.75 \mathrm{E}-4 \mathrm{mLs}^{-1}$. . . . . . . . . . . 76

F.3 Percolation pressure for VD420 at 37.08E-4 $\mathrm{mLs}^{-1}$. . . . . . . . . . . 77

F.4 $\quad$ Percolation pressure for VD421 at $9.48 \mathrm{E}-4 \mathrm{mLs}^{-1}$. . . . . . . . . . . . 78

F.5 $\quad$ Percolation pressure for VD421 at $18.75 \mathrm{E}-4 \mathrm{mLs}^{-1}$. . . . . . . . . . . 79

F.6 $\quad$ Percolation pressure for VD421 at $37.08 \mathrm{E}-4 \mathrm{mLs}^{-1}$. . . . . . . . . . . 80

F.7 $\quad$ Percolation pressure for VD423 at $9.48 \mathrm{E}-4 \mathrm{mLs}^{-1}$. . . . . . . . . . . . 81

F.8 $\quad$ Percolation pressure for VD423 at $18.75 \mathrm{E}-4 \mathrm{mLs}^{-1}$. . . . . . . . . . . . 82

F.9 $\quad$ Percolation pressure for VD423 at $37.08 \mathrm{E}-4 \mathrm{mLs}^{-1}$. . . . . . . . . . . . 83

F.10 Percolation pressure for VD422 at $9.48 \mathrm{E}-4 \mathrm{mLs}^{-1}$. . . . . . . . . . . . 84

F.11 Percolation pressure for VD422 at $18.75 \mathrm{E}-4 \mathrm{mLs}^{-1}$. . . . . . . . . . . 85

F.12 Percolation pressure for VD422 at $37.08 \mathrm{E}-4 \mathrm{mLs}^{-1}$. . . . . . . . . . 86 
F.13 Percolation pressure for VD424 at $9.48 \mathrm{E}-4 \mathrm{mLs}^{-1}$. . . . . . . . . . . . 87

F.14 Percolation pressure for VD424 at $18.75 \mathrm{E}-4 \mathrm{mLs}^{-1}$. . . . . . . . . . . 88

F.15 Percolation pressure for VD424 at $37.08 \mathrm{E}-4 \mathrm{mLs}^{-1}$. . . . . . . . . . . 89

F.16 Percolation pressure for VD425 at $9.48 \mathrm{E}-4 \mathrm{mLs}^{-1}$. . . . . . . . . . . . 90

F.17 Percolation pressure for VD425 at $18.75 \mathrm{E}-4 \mathrm{mLs}^{-1} \ldots$. . . . . . . . . . 91

F.18 Percolation pressure for VD425 at 37.08E-4 $\mathrm{mLs}^{-1}$. . . . . . . . . . . 92

F.19 Percolation pressure for VD432 at $9.48 \mathrm{E}-4 \mathrm{mLs}^{-1}$. . . . . . . . . . . . 93

F.20 Percolation pressure for VD432 at $18.75 \mathrm{E}-4 \mathrm{mLs}^{-1}$. . . . . . . . . . . 94

F.21 Percolation pressure for VD432 at 37.08E-4 $\mathrm{mLs}^{-1}$. . . . . . . . . . . 95

F.22 Percolation pressure for VD436 at $9.48 \mathrm{E}-4 \mathrm{mLs}^{-1}$. . . . . . . . . . . . 96

F.23 Percolation pressure for VD436 at $18.75 \mathrm{E}-4 \mathrm{mLs}^{-1}$. . . . . . . . . . . 97

F.24 Percolation pressure for VD436 at $37.08 \mathrm{E}-4 \mathrm{mLs}^{-1}$. . . . . . . . . . . 98

F.25 Percolation pressure for VD328 at $9.48 \mathrm{E}-4 \mathrm{mLs}^{-1}$. . . . . . . . . . . . 99

F.26 Percolation pressure for VD328 at $18.75 \mathrm{E}-4 \mathrm{mLs}^{-1}$. . . . . . . . . . . 100

F.27 Percolation pressure for VD328 at $37.08 \mathrm{E}-4 \mathrm{mLs}^{-1}$. . . . . . . . . . . 101

F.28 Percolation pressure for VD302 at 9.48E-4 $\mathrm{mLs}^{-1}$. . . . . . . . . . . . 102

F.29 Percolation pressure for VD302 at $18.75 \mathrm{E}-4 \mathrm{mLs}^{-1}$. . . . . . . . . . . 103

F.30 Percolation pressure for VD302 at 37.08E-4 $\mathrm{mLs}^{-1}$. . . . . . . . . . . 104

H.1 Summary of percolation pressure growth rate on VD420. . . . . . . . 116

H.2 Summary of percolation pressure growth rate on VD421. . . . . . . . 117

H.3 Summary of percolation pressure growth rate on VD423. . . . . . . . . 118

H.4 Summary of percolation pressure growth rate on VD422. . . . . . . . 119

H.5 Summary of percolation pressure growth rate on VD424. . . . . . . . 120

H.6 $\quad$ Summary of percolation pressure growth rate on VD425. . . . . . . . . 121

H.7 $\quad$ Summary of percolation pressure growth rate on VD432. . . . . . . . . 122

H.8 Summary of percolation pressure growth rate on VD436. . . . . . . . . 123

H.9 Summary of percolation pressure growth rate on VD328. . . . . . . . . 124

H.10 Summary of percolation pressure growth rate on VD302. . . . . . . . 125

I.1 Percolation pressure vs wetted volume for VD420 at 9.48E-4 $\mathrm{mLs}^{-1}$. . 127

I.2 $\quad$ Percolation pressure vs wetted volume for VD420 at $18.75 \mathrm{E}-4 \mathrm{mLs}^{-1}$. 128

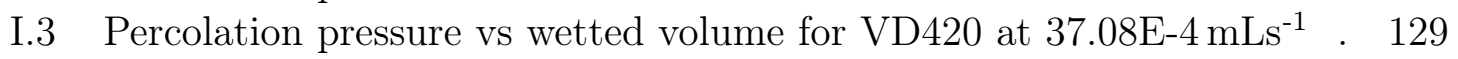

I.4 Percolation pressure vs wetted volume for VD420 at $9.48 \mathrm{E}-4 \mathrm{mLs}^{-1}$. . 130

I.5 Percolation pressure vs wetted volume for VD421 at $18.75 \mathrm{E}-4 \mathrm{mLs}^{-1}$. 131

\begin{tabular}{lll}
\hline I.6 & Percolation pressure vs wetted volume for VD421 at $37.08 \mathrm{E}-4 \mathrm{mLs}^{-1}$ \\
\hline
\end{tabular}

I.7 $\quad$ Percolation pressure vs wetted volume for VD423 at $9.48 \mathrm{E}-4 \mathrm{mLs}^{-1}$. . 133

I.8 $\quad$ Percolation pressure vs wetted volume for VD423 at $18.75 \mathrm{E}-4 \mathrm{mLs}^{-1}$. 134

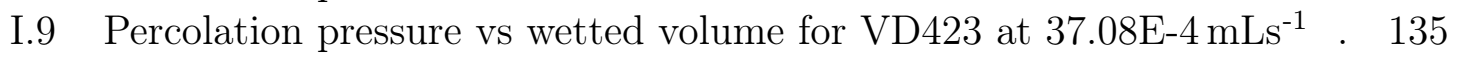

I.10 Percolation pressure vs wetted volume for VD422 at $9.48 \mathrm{E}-4 \mathrm{mLs}^{-1}$. . 136

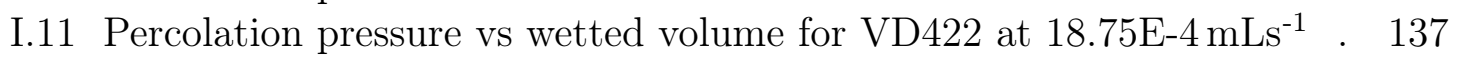


1.12 Percolation pressure vs wetted volume for VD422 at $37.08 \mathrm{E}-4 \mathrm{mLs}^{-1}$. 138

I.13 Percolation pressure vs wetted volume for VD424 at $9.48 \mathrm{E}-4 \mathrm{mLs}^{-1}$. . 139

I.14 Percolation pressure vs wetted volume for VD424 at $18.75 \mathrm{E}-4 \mathrm{mLs}^{-1}$. 140

I.15 Percolation pressure vs wetted volume for VD424 at $37.08 \mathrm{E}-4 \mathrm{mLs}^{-1}$. 141

I.16 Percolation pressure vs wetted volume for VD425 at $9.48 \mathrm{E}-4 \mathrm{mLs}^{-1}$. . 142

I.17 Percolation pressure vs wetted volume for VD425 at $18.75 \mathrm{E}-4 \mathrm{mLs}^{-1}$. 143

I.18 Percolation pressure vs wetted volume for VD425 at $37.08 \mathrm{E}-4 \mathrm{mLs}^{-1}$. 144

I.19 Percolation pressure vs wetted volume for VD432 at 9.48E-4 $\mathrm{mLs}^{-1}$. . 145

I.20 Percolation pressure vs wetted volume for VD432 at $18.75 \mathrm{E}-4 \mathrm{mLs}^{-1}$. 146

\begin{tabular}{lll}
\hline I.21 & Percolation pressure vs wetted volume for VD432 at $37.08 \mathrm{E}-4 \mathrm{mLs}^{-1}$ \\
\hline
\end{tabular}

I.22 Percolation pressure vs wetted volume for VD436 at $9.48 \mathrm{E}-4 \mathrm{mLs}^{-1}$. . 148

I.23 Percolation pressure vs wetted volume for VD432 at $18.75 \mathrm{E}-4 \mathrm{mLs}^{-1}$. 149

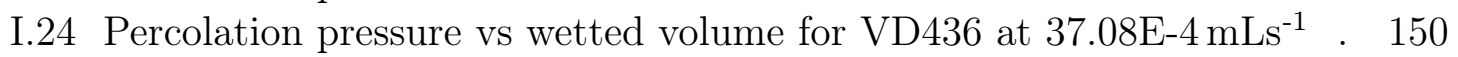

I.25 Percolation pressure vs wetted volume for VD328 at 9.48E-4 $\mathrm{mLs}^{-1}$. . 151

I.26 Percolation pressure vs wetted volume for VD328 at $18.75 \mathrm{E}-4 \mathrm{mLs}^{-1}$. 152

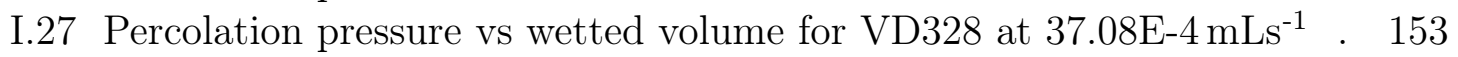

I.28 Percolation pressure vs wetted volume for VD302 at 9.48E-4 mLs ${ }^{-1}$. . 154

I.29 Percolation pressure vs wetted volume for VD302 at $18.75 \mathrm{E}-4 \mathrm{mLs}^{-1}$. 155

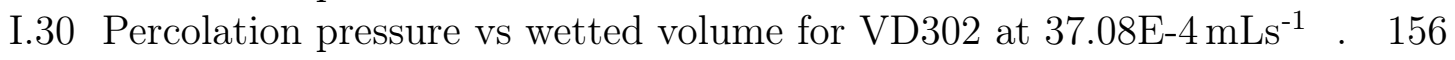

J.1 $\quad$ Permeability for VD420. . . . . . . . . . . . . . . . . . . . . . . . . . 158

J.2 $\quad$ Permeability for VD421. . . . . . . . . . . . . . . . . . . . . . . . . . 159

J.3 $\quad$ Permeability for VD423. . . . . . . . . . . . . . . . . . . . . . . 160

J.4 $\quad$ Permeability for VD422. . . . . . . . . . . . . . . . . . . . . . . . . 161

J.5 $\quad$ Permeability for VD424. . . . . . . . . . . . . . . . . . . . . . . . 162

J.6 $\quad$ Permeability for VD425. . . . . . . . . . . . . . . . . . . . . . . . . . 163

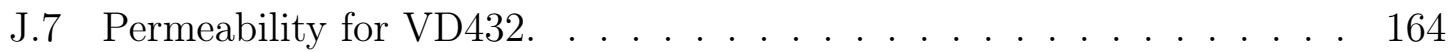

J.8 $\quad$ Permeability for VD436. . . . . . . . . . . . . . . . . . . . . . . 165

J.9 $\quad$ Permeability for VD328. . . . . . . . . . . . . . . . . . . . . . 166

J.10 Permeability for VD302. . . . . . . . . . . . . . . . . . . . 167 


\section{LIST OF TABLES}

3.1 Properties of FC-3283 ${ }^{\mathrm{TM}}$ and liquid water . . . . . . . . . . . . . . . 11

3.2 Catalyst Layer testing conditions . . . . . . . . . . . . . . . . . . . 12

4.1 Percolation pressures of PTL samples tested . . . . . . . . . . . . . . 18

5.1 List of Non-Run Catalyst Layer samples with properties. . . . . . . . 27

\begin{tabular}{|lll}
5.2 & List of Aged and Conditioned Catalyst Layer samples with properties. 28
\end{tabular}

5.3 Summary of VD423 Percolation Pressure testing results . . . . . . . . 30

G.1 Summary of VD420 Percolation Pressure tests . . . . . . . . . . . . . 105

G.2 Summary of VD421 Percolation Pressure tests . . . . . . . . . . . . . 106

G.3 Summary of VD423 Percolation Pressure tests . . . . . . . . . . . . . 107

G.4 Summary of VD422 Percolation Pressure tests . . . . . . . . . . . . . 108

G.5 Summary of VD424 Percolation Pressure tests . . . . . . . . . . . . . 109

G.6 Summary of VD425 Percolation Pressure tests . . . . . . . . . . . . . 110

G.7 Summary of VD432 Percolation Pressure tests . . . . . . . . . . . . . 111

G.8 Summary of VD436 Percolation Pressure tests . . . . . . . . . . . . . . 112

G.9 Summary of VD328 Percolation Pressure tests . . . . . . . . . . . . . 113

G.10 Summary of VD302 Percolation Pressure tests . . . . . . . . . . . . . 114 


\section{ACKNOWLEDGMENTS}

I want to take this chance to thank my advisor Dr. Jeffrey S. Allen for his guiding support throughout my graduate studies as well as the time I was able to work under Dr. Allen in my undergraduate. His advice and gratitude in all I have accomplished has been priceless.

I would like to personally thank Ezequiel F. Medici for his friendship, assistance and encouragement. I would also like to thank Mark Nettell for his assistance with the experiments.

I want to thank all the friends in the MnIT research group that accepted me and helped me so much as well as the many friends and family that supported me throughout my time here at Michigan Tech.

Lastly I want to give a special thank you to my loving wife Yiqian Zhao, who without her support I would not have finished this work.

This work was partially supported under U.S. Department of Energy contract DE-EE0000466 in cooperation with Ballard Power Systems. 


\section{ABSTRACT}

\section{CHARACTERIZATION OF POROUS MEDIA IN PROTON EXCHANGE MEM- BRANE FUEL CELL BASED ON PERCOLATION STUDIES}

Stephen Stacy

Michigan Technological University, 2013

Advisor: Dr. Jeffrey S. Allen

Water management in the porous media of proton exchange membrane (PEM) fuel cells, catalyst layer and porous transport layers (PTL) is confronted by two issues, flooding and dry out, both of which result in improper functioning of the fuel cell and lead to poor performance and degradation.

The data that has been reported about water percolation and wettability within a fuel cell catalyst layer is limited to porosimetry. A new method and apparatus for measuring the percolation pressure in the catalyst layer has been developed. The experimental setup is similar to a Hele-Shaw experiment where samples are compressed and a fluid is injected into the sample. Pressure-Wetted Volume plots as well as Permeability plots for the catalyst layers were generated from the percolation testing.

PTL samples were also characterizes using a Hele-Shaw method. Characterization for the PTLs was completed for the three states: new, conditioned and aged. This is represented in a Ce-t* plots, which show a large offset between new and aged samples. 


\section{INTRODUCTION}

Proton Exchange Membrane (PEM) Fuel Cells have gained a lot of interest in the past decades because of their potential to replace the IC engine. This is due to their low emission production and high power density output.[1] However, water management poses a major problem for PEM fuel cells, which must be dealt with before commercialization in the automotive industry and in the stationary applications industry.

In a hydrogen PEM fuel cell, there are two reactants, hydrogen gas on the anode side and air (oxygen) on the cathode. The hydrogen gas is oxidized to protons and electrons. The protons move through the membrane to the cathode, while the electron moves through an electric circuit outside the cell providing electricity. The protons transferred to the cathode combine with reduced oxygen and the electrons to form water and heat, at the catalyst sites.

A diagram of a basic PEM fuel cell is shown in Figure 1.1. PEM fuel cells are comprised of two sides, the anode and cathode. The anode and cathode are made up of the porous media called the Porous Transport Layer (PTL) and the catalyst layer. The PTL also called the Gas Diffusion Layer (GDL) has many purposes, including transfer of the reactants to the catalyst sites and removal of waste byproducts. The PTL is coated with polytetrafluoroethylene (PTFE), which renders the surface non-wetting. The catalyst layer is usually made from carbon blacks with platinum or platinum-alloy nanoparticles attached to the carbon. The makeup of the catalyst layer will be talked about later when discussing a model for the catalyst layer[2]. Sandwiched between the anode and cathode is the Proton Exchange Membrane (PEM). The membrane has the main job of transferring the protons from the hydrogen across the cell to the cathode side while rejecting electrons, hydrogen, and oxygen from crossing the cell. The membrane has the catalyst layer coated onto it to improve the reaction. The cathode and anode media and PEM are within the bipolar plates, which dispense the reactants to each side of the cell through the gas channels.

Flooding and dryout are the two main concerns involved with water management in PEM fuel cells. If the PEM fuel cell dries, proton transport through the membrane will decrease which will cause loss of performance and will lead to material damage. If flooding occurs then operation of the fuel cell will slow due to reactant and product transport through the catalyst layer and PTL. Water will cause blockages in which 


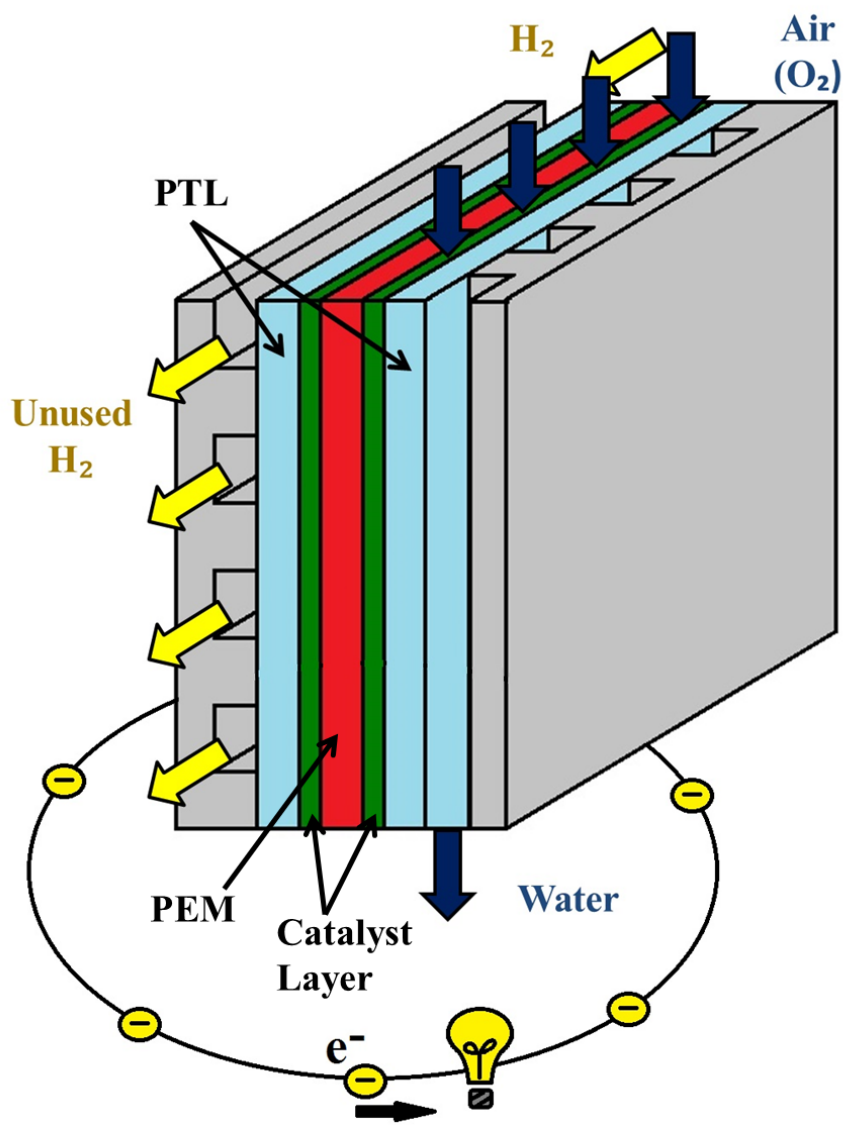

Figure 1.1. PEM Fuel Cell 
reactants cannot reach the catalyst layer. The porous media are the PTL and the catalyst layer. These both have different jobs and, while in the micro-scale, are of quite different magnitudes in sizes. The PTL is on a much larger micro-scale size and is there for transfer of the products and reactants, while the catalyst layer is there for different purposes. The liquid water in the catalyst layer comes from electrochemical reactions, on the cathode side, or it will be brought in from the membrane. 3]

The work presented in this thesis has been put together to study and characterize the porous media within a PEM fuel cell, PTL and catalyst layer. The study has been focused on experimental testing to extract data from the porous media so as to understand the differences from being aged in a fuel cell or not run. The work is presented separately between the PTL and the catalyst layer.

\subsection{PTL Motivation}

The research that is presented in this study builds upon the research Medici and Allen [4]. The PTL part of this research focuses on the understanding of the characterization methods put forward by Medici in which he uses percolation experiments to understand the transport properties of the PTL of the PEM Fuel Cell. The PTL materials that were used in the study are labeled as Non-Run or beginning of life, Conditioned, or Aged where the aging took place in an accelerated stress test.

The main goals of this study are to detect and characterize the structural changes due to aging of the PTL and validate the techniques used by Medici on other PTL materials and aged PTL.

\subsection{Motivation}

In the catalyst layer the water is not only being transported through but it is also being generated. Therefore controlling the amount of liquid water in the catalyst layer creates issues, because for efficient operation of the PEM fuel cell flooding and dryout must not occur.

For the second part of this study, Catalyst Layer from PEM Fuel Cells will be used following similar experimental testing to that of the PTL. For the study on the Catalyst Layer, the goals were to construct a working experimental setup to gain repeatable results for Percolation experiments, characterize a variety of samples with different weight percentage of ionomer count and Platinum loading, and to characterize the structural changes due to aging. 


\section{Drainage VS. IMBIBITION}

Percolation is a broad term describing to describe fluid transport in a porous media. Transport could exist as a one-phase, air passing through an air filter, or two-phase, water displacing air inside porous media, which has been a topic of research for a long time. [5] [6] [7] PEM fuel cells are the focus of this study which have a 2-phase flow. 2-phase fluid transport through porous medium consists of two behaviors, drainage and imbibition. Drainage being the displacement of a wetting fluid by a non-wetting fluid and imbibition being the displacement of a non-wetting fluid by a wetting fluid. In drainage, the pressure to inject the non-wetting fluid has to overcome the capillary pressure, where as in imbibition, the capillary pressure is responsible for pulling the wetting fluid into the porous media. This is also called wicking or spontaneous imbibition. [8] With both drainage and imbibition there are different types of fluid flow behavior.

Drainage consists of 3 different fluid flow behaviors seen in porous media: stable displacement, viscous fingering, and capillary fingering. These three flow behaviors can be characterized by two non-dimensional parameters. The Capillary Number and the Viscosity Ratio, seen in equations 2.1 and 2.2. The Capillary Number, designated $\mathrm{Ca}$, consists of the average velocity of the injected or displacing fluid, the viscosity of the displacing fluid, and the interfacial tension between the two fluids. The Viscosity Ratio, designated $M$, is the ratio of the viscosity of the displacing fluid to the viscosity of the displaced fluid. These two characteristics are helpful in deciding which force factor (viscous or capillary) is governing the fluid displacement behavior. [9] The information from these two characteristics is shown on phase diagrams in Figure 2.1 with $\mathrm{Ca}$ and $\mathrm{M}$ as the axes. Fluid flow behaviors can be determined using this chart if properties of the fluid and the morphology and wettability of the porous medium are known.

$$
\begin{gathered}
\mathrm{Ca}=\frac{U_{\text {displacing }} \mu_{\text {displacing }}}{\sigma} \\
\mathrm{M}=\frac{\mu_{\text {displacing }}}{\mu_{\text {displaced }}}
\end{gathered}
$$

In Figure 2.1, three different flow regimes are delineated. During capillary finger- 
ing, the viscosity ratio is high and Ca small. Having a relatively slow flow rate allows the injection fluid with time to choose a path of least resistance. The displacing fluid will form fingers of different sizes. Stable displacement also has a high viscosity ratio however the flow rate increases greatly leading to much larger $\mathrm{Ca}$, which results in the displacing fluid to spread evenly through the porous media. Viscous fingering has a much smaller viscosity ratio and occurs at a high flow rate. With a low viscosity ratio the injecting fluid is pushing into the more viscous fluid with a greater resistance. Having a high flow rate does not give the fluid time to chose its path as in capillary fingering but still pushes it out in all directions like stable displacement. However, there is a large resistance fighting this fluid, which causes the spreading of the fluid through the porous media to create fingers of roughly the same size. For this study only stable displacement and capillary fingering were included for PTL characterization.

Imbibition is the other displacement behavior of fluids in porous media. In imbibition, there are 4 different fluid behaviors. As in drainage, stable displacement and viscous fingering act in the same way. Capillary fingering is split into two sub categories, continuous and discontinuous, which means that the flow will separate and form separate liquid plugs or islands in separate parts of the porous media, according to Lenormand [10] He describes imbibition in porous media to have a large and small aspect ratio, where the aspect ratio is the pore to throat ratio. If the large aspect ratio is present, the driving force is the displacing fluid will breach the smallest channel without entering the pore, this is just the opposite for the small aspect ratio in which it invades the pores then channels connecting the pores. The imbibition phase diagram put forth by Lenormand [10] is shown in Figure 2.1b. During this study, stable displacement is the only flow regime that will be used, so as to test all pores in the catalyst layer, allow for properties of the catalyst layer to be explored. 


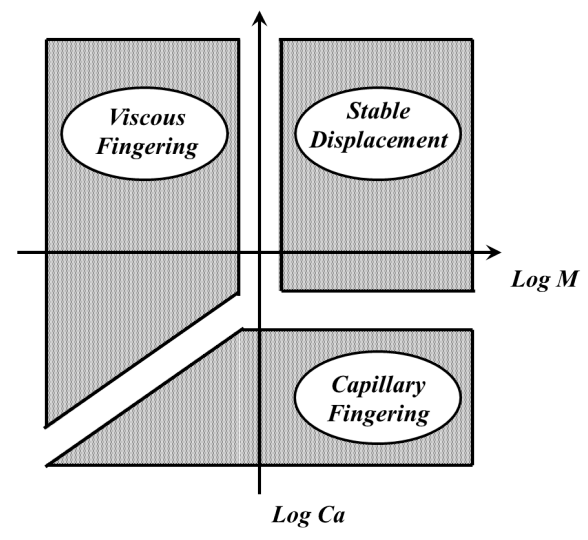

(a) Drainage

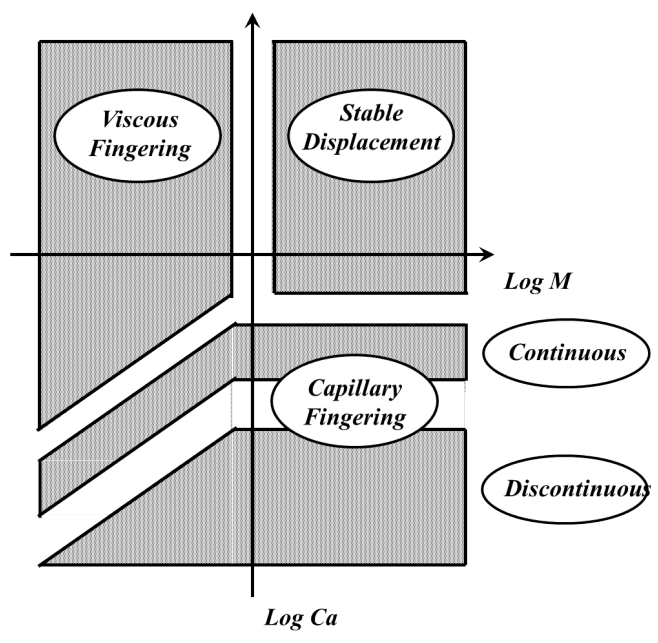

(b) Imbibition

Figure 2.1. Phase diagrams for two-phase flow in porous media. 10] 


\section{EXPERIMENTAL SETUP}

There were two separate experimental setups for this study of the percolation in the porous transport layer and catalyst layer. Ballard Power Systems (Vancouver, British Columbia, Canada) supplied the PTLs and catalyst layers, which were specifically designed for the studies supported under DOE contract DE-EE0000466.

\subsection{Porous Transport Layer Experiment}

This study examined several different PTL, with and without a microporous layer (MPL). The samples are designated as Non-Run, Conditioned, or Aged and only one sample that had no MPL referred to as substrate. Non-Run samples were never conditioned nor aged. Conditioning is a process that is used to humidify the MEA after preparation and to ensure stable performance. This is done for all fuel cells and fuel cell stacks. Aged PTLs underwent accelerated stress tests (AST). The AST used accelerated the cathode catalyst layer degradation mechanisms only. Membrane and anode degradation was not accelerated. These are the different types of samples that were used in the percolation studies for PTLs as well as for the percolation studies for the CLs. Both the cathode and anode PTLs were used in testing.

The setup for PTL percolation pressure characterization, can be seen in a diagram in Figure 3.1, which consists of compressing the PTL sample between two platens, one made of Polymethylmethacrylate (PMMA) coated with Polydimethylsiloxane (PDMS), and the other platen is constructed of a thick layer of PDMS with micro-tubing in the center. PDMS is a silicone material that is transparent allowing the camera to view the testing sample. PDMS is also compliant and hydrophobic which seals the PTL sample during testing. The PTL sample is cut in a circular shape at $5.4 \mathrm{~cm}$ (2.13 inches) in diameter from a large sheet of PTL, the bottom platen is much larger while the top platen is $4.7 \mathrm{~cm}$ (1.88 inches) in diameter, which allows air to evacuate from the edge of the sample when the sample is placed between the platens and compressed. During tests, the platens are compressed to a pressure of $27.58 \mathrm{kPa}$ (4 psi) using a Parker air cylinder Model No. TB2MAUVS19. The test liquid is injected into the PTL at the center of the sample, through the polytetrafluoroethylene (PTFE) micro-tubing that is connected to the bottom platen. The test fluid chosen 


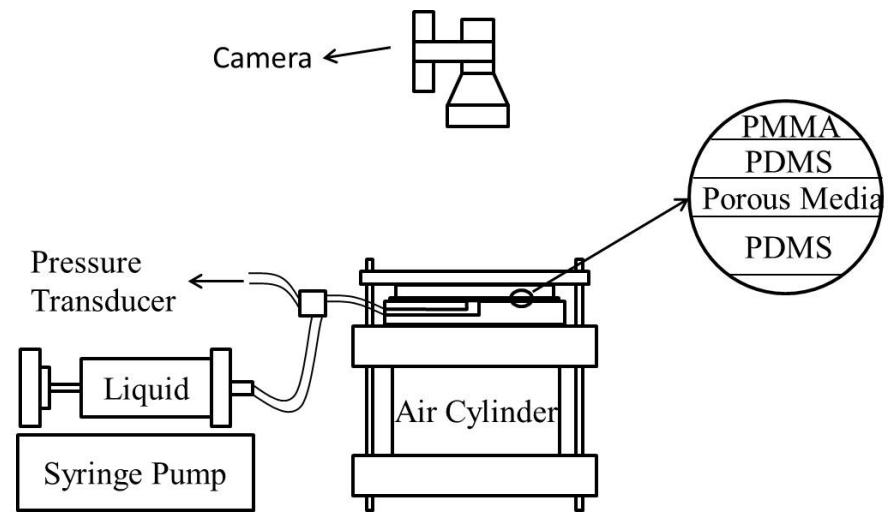

Figure 3.1. Schematic representation of the experimental setup that is used for testing the percolation in the PTL.

for this study is distilled water. A Panasonic GP-KS125 CCD camera was used to record images at $0.033,0.166,1.8$, and 4.5 frames per second (fps). The images were collected using EPIX PIXCI frame grabber and XCAP software. Pressure data was synchronized with video imaging of the percolation. Two Harvard Apparatus syringe pumps was used for high speed injection for stable displacement, Model No. 944, and low injection for capillary fingering, Model No. 2274, with a $3 \mathrm{ml}$ and $10 \mathrm{~mL}$ gas-tight Hamilton syringe. A pressure transducer, Omegadyne ${ }^{\circledR}$ model PX209-030G10V, read the percolation pressure within the PTL at intervals of 1, 0.1, 0.02, and 0.01 seconds depending on the fluid injection rate. A picture of the PTL setup can be seen in Figure 3.2 .

\subsection{Catalyst Layer Experimental Setup}

The experimental setup for Catalyst Layer tests has a design similar to that of the PTL setup. The Catalyst Layer experiments were first conducted testing two different catalyst layer samples transferred to a Polymer Film. These samples were referred to as CCF samples or Catalyst Coated Film. These samples were tested on the pseudo Hele-Shaw setup for the PTL samples as a feasibility study, concluding first that results could be found and if the samples would show repeatability.

The CCF samples, being used for the percolation study, were changed to two new catalyst layer samples transferred to a Nafion membrane rather than a polymer film. These samples were only transferred to one side of the membrane. The two catalyst layers are referred to as Process 1 and Process 2. The composition of the samples were identical, but they were produced using different processes. Both samples contained a membrane with a backing layer which made the structure much more rigid and thicker. The thickness of the catalyst layers was $12 \mu \mathrm{m}$ on a $24 \mu \mathrm{m}$ thick membrane. 


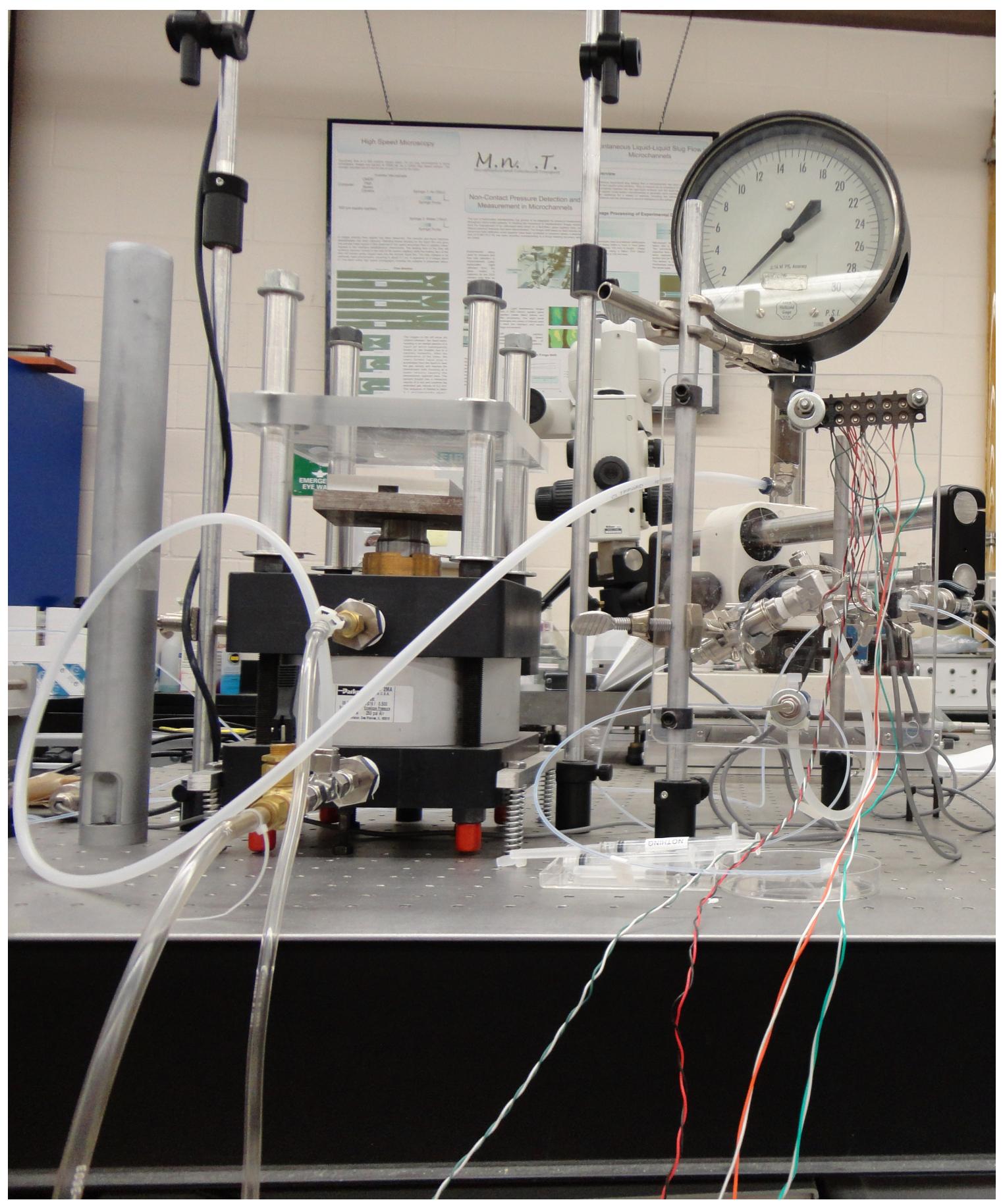

Figure 3.2. PTL experimental setup 


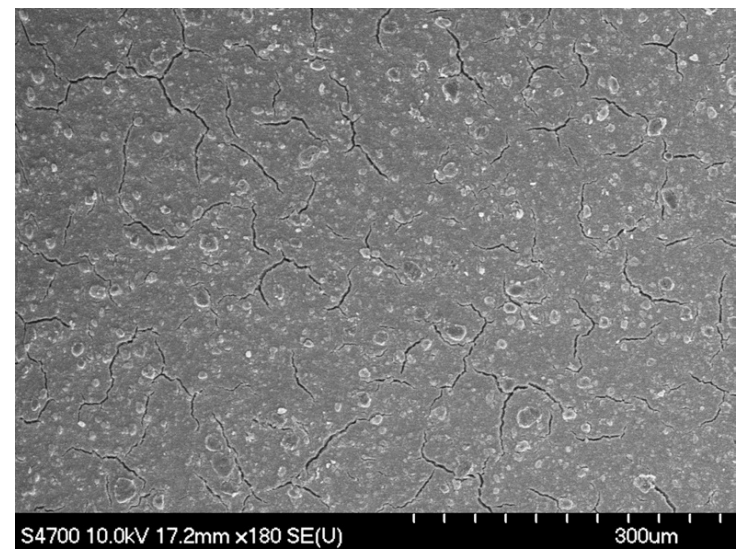

(a) Process 1 at 180x

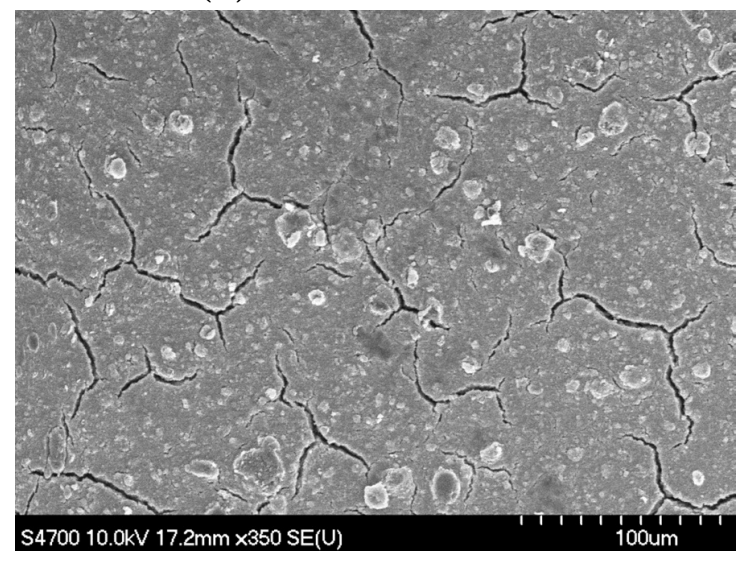

(c) Process 1 at 350x

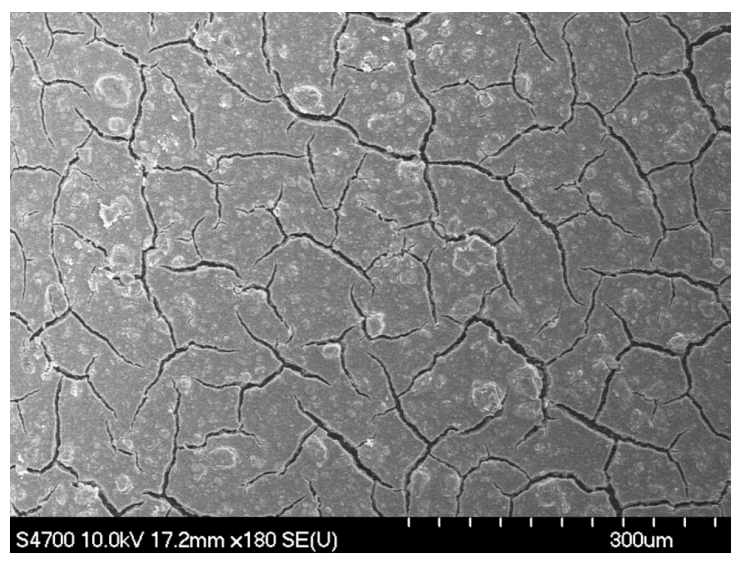

(b) Process 2 at 180x

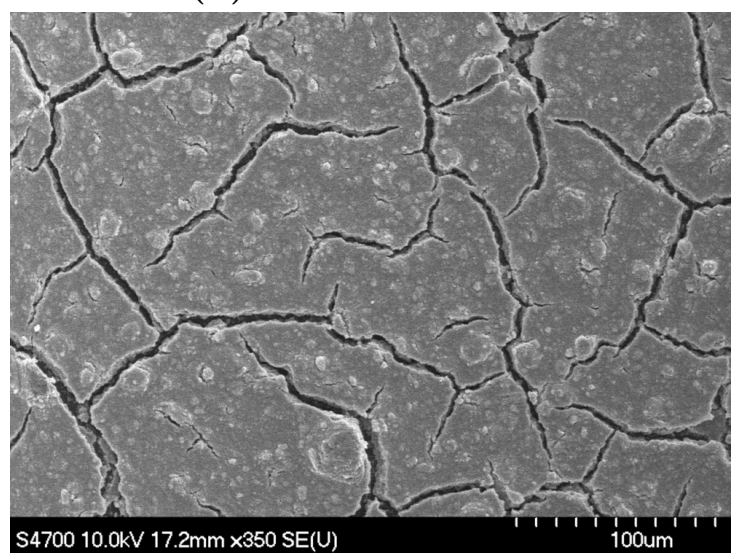

(d) Process 2 at $350 \mathrm{x}$

Figure 3.3. SEM image of the catalyst layers tested. On the left is Process 1 , on the right is Process 2.

An SEM image of both samples can be seen in Figure 3.3. Once the experimental setup was completed and collecting repetitive data a new set of catalyst layers would replace the Process 1 and Process 2 samples for final testing. The new catalyst layers are called full Catalyst Coated Membranes (CCM), which are transfered to both sides of the membrane, the same as in a working fuel cell.

The Process 1 and Process 2 samples were used to design the Catalyst Layer percolation experiment. A $4 \mathrm{~cm} \times 5.5 \mathrm{~cm}$ (1.58 in $\times 2.17 \mathrm{in})$ section of the catalyst layer was placed between two platens made of Polymethylmethacrylate (PMMA) and compressed between by an air cylinder, as shown in Figure 3.4. The bottom platen was designed with a channel, drilled through for fluid passage. This type of test setup is referred to as a pseudo Hele-Shaw setup, just as the PTL setup. The liquid was not able to be injected from the top of the sample due to full CCM's being opaque 
the camera was setup underneath the setup to film while the injection occurred from underneath. A picture of the Catalyst Layer setup can be seen in Figure 3.5.

The fluid chosen for percolation tests in the catalyst layer is FC-3283, a fluorinert from $3 \mathrm{M}^{\mathrm{TM}}$. FC-3283 is a liquid with stable transport properties and is colorless, clear, thermally and chemically stable, and is a fully-fluorinated fluid.[1] Unlike water, Fritz [11] showed FC-3283 has no uptake in the ionomer and is not a solvent to the ionomer. After testing the FC-3283 on a full CCM, the fluid shows that it is a wicking fluid to the catalyst layer, which will in result in spontaneous imbibition.

Table 3.1. Fluid properties of $3 \mathrm{M}$ Fluorinert FC-3283 ${ }^{\mathrm{TM}}$ and liquid water. 12 14

\begin{tabular}{|c|c|c|}
\hline Fluid Properties & FC-3283 & Water \\
\hline Density (g/cm $\mathbf{3}$ ) & 1.82 & 0.998 \\
Kinematic Viscosity (cS) & 0.75 & 1.004 \\
Surface Tension (dynes/cm) & 16 & 72.8 \\
Solubility of Water (ppm(wt.)) & 7 & \\
Vapor Pressure (torr) & 11 & 17.54 \\
Refractive Index & 1.281 & 1.333 \\
\hline
\end{tabular}

The platens containing the sample are compressed to a pressure of $68.9 \mathrm{kPa}$ (10 psi) via a Parker air cylinder Model No. TB2MAUVS19. A Panasonic GP-KS125 CCD camera recorded images at $0.9,1.8,4.5$, and 9 frames per second (fps). The conditions that were set for testing are listed in Table 3.2. Pressure data was synchronized with video imaging of the percolation. Images were collected using a EPIX PIXCI frame grabber and XCAP software. The liquid is being injected into the catalyst layer through polytetrafluoroethylene (PTFE) micro-tubing. The tubing is connected to the bottom platen that has a flow passage for liquid injection. The fluid is injected into the center of the sample. A syringe pump, Harvard Apparatus Model No. 944, was

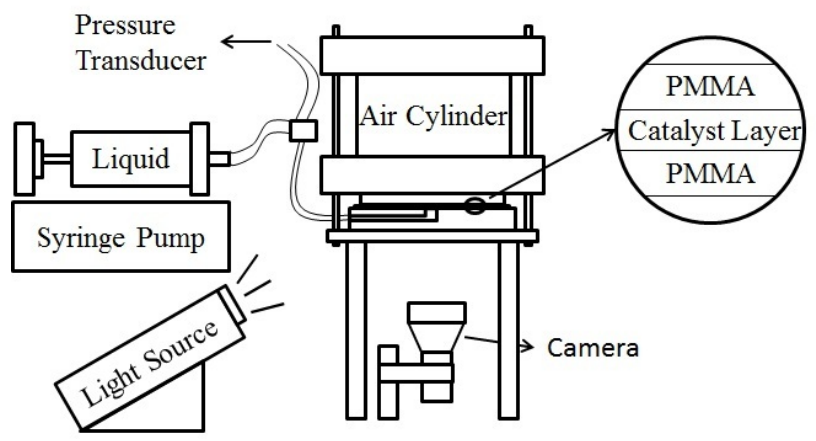

Figure 3.4. Schematic representation of the experimental setup that is used for testing the percolation in the catalyst layer. 
used at three different speeds with a $2.5 \mathrm{ml}$ gas-tight Hamilton syringe. A pressure transducer, Omegadyne ${ }^{\circledR}$ model PX209-30V15G10V, read the percolation pressure within the catalyst layer at intervals of $0.04,0.02$, and 0.01 seconds depending on the fluid injection rate.

Table 3.2. Catalyst Layer testing conditions

\begin{tabular}{|c|c|c|}
\hline $\mathrm{Q}(\mathrm{mL} / \mathrm{s})$ & Frame Rate (fps) & Data Acquisition $(\mathrm{Hz})$ \\
\hline $9.483 \mathrm{E}-4$ & 0.9 & 25 \\
$18.75 \mathrm{E}-4$ & 1.8 & 50 \\
$37.08 \mathrm{E}-4$ & 4.5 & 100 \\
$37.08 \mathrm{E}-4$ & 9 & 100 \\
\hline
\end{tabular}

With a working experimental setup producing repeatable data on the Process 1 and Process 2 samples, the full CCM catalyst layer samples were then tested. Changing to the full CCM samples required modifications on the platens. The platen was made into a square to have better representation of the spreading that occurs during testing as well as decreasing the size to $3.8 \mathrm{~cm} \mathrm{x} 3.8 \mathrm{~cm}$ (1.496 in x $1.496 \mathrm{in}$ ) changed to a $3.8 \mathrm{~cm} \times 3.8 \mathrm{~cm}$ to account for the area of full CCM that is supplied. 


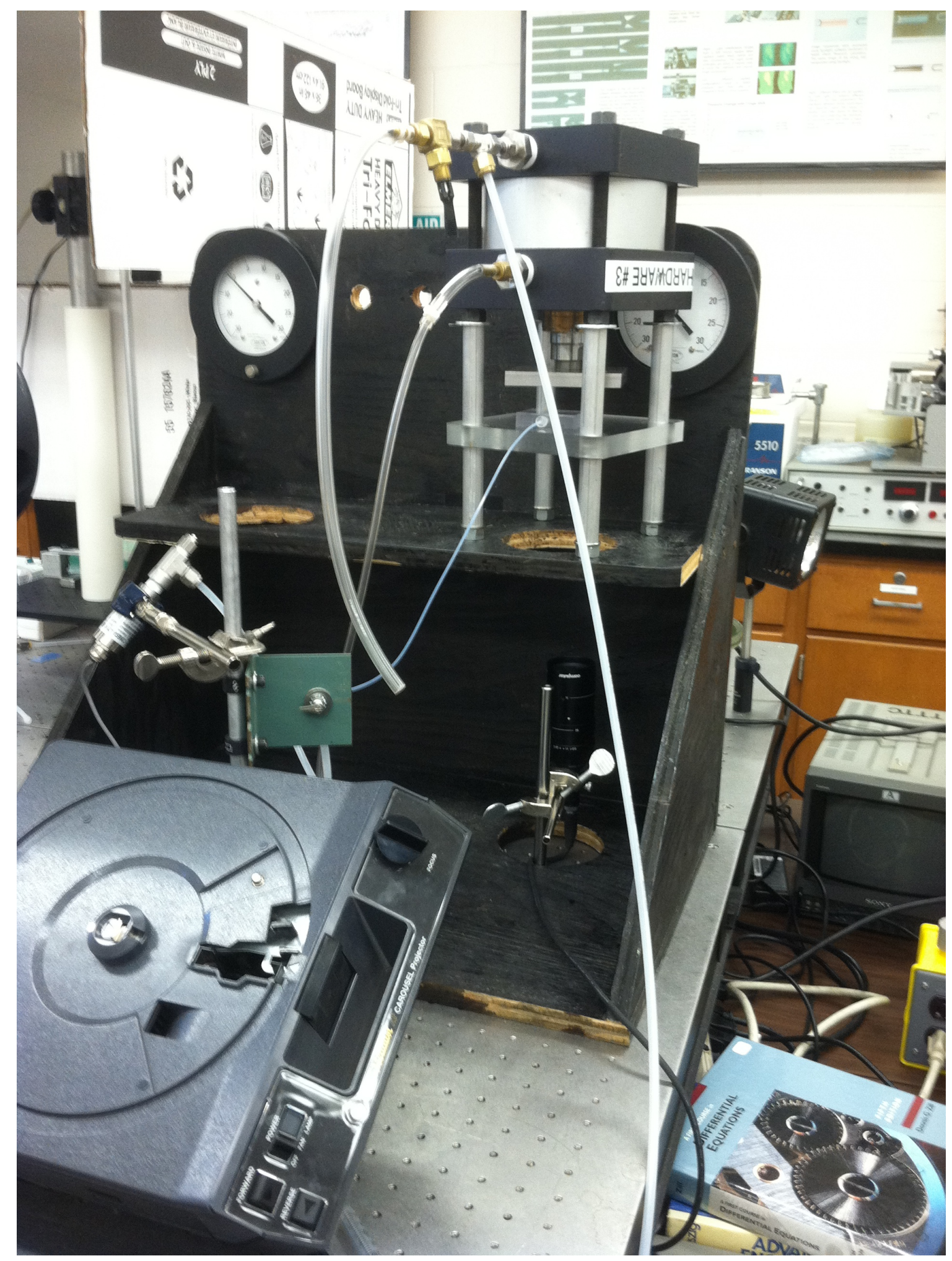

Figure 3.5. Catalyst Layer experimental setup 


\section{PTL Characterization}

In the PTL study, the goal was to characterize structural changes due to aging, whilst validating characterization methods used by Medici [15]. Ballard Power Systems (Vancouver, British Columbia, Canada) supplied the PTLs and catalyst layers, which were specifically designed for the studies supported under DOE contract DEEE0000466.

From the three flow regimes, two were tested using the PTL samples. Capillary fingering was tested using two different injection rates, resulting in two different capillary numbers. Figure 4.1 shows capillary fingering using a flow rate of $7.29 \mathrm{E}-6 \mathrm{mLs}^{-1}$ and a capillary number of 3.77E-8. The other flow regime that was tested during this study was stable displacement. Stable displacement is shown in Figure 4.2 at a flow rate of $5.15 \mathrm{E}-3 \mathrm{mLs}^{-1}$ and a capillary number of $2.66 \mathrm{E}-5$. In both Figures, the solid (yellow) line represents the interface between the two fluids in this case water and air, water being inside the line. This line was computer generated during post processing.

During testing of the samples the percolation pressure or capillary pressure was recorded. During stable displacement, the pressure always increases. Capillary fingering has a rising pressure that plateaus or peaks. Figure 4.3 shows a pressure plot from a single PTL test. The data for each sample at different capillary numbers is shown in Table 4.1. Four different injection flow rates were used for each sample as shown by four different capillary numbers. The highest capillary number (far right column) resulted in a stable displacement (SD) flow regime in which the percolation pressure did not plateau. The magnitude of the reference capillary numbers in Table 4.1 vary slightly due to a change in the test setup during the course of this project. The small change does not alter the flow behavior observed.

From Table 4.1, the pressures differ quite substantially between the cathode and anode. The anode has higher pressures than the cathode PTLs for the same rate of injection, which indicates the cathode has a higher permeability. All the cathode samples keep a much more consistent pressure between the non-run, conditioned and aged samples, whereas the anode samples show a difference between the three.

Characterization of the PTL samples used the Ce- $t^{*}$ method that was proposed by Medici and Allen [9], using Equations 4.1 and 4.2. The Ce- $\mathrm{t}^{*}$ is a ratio of the magnitude of the energy that is injected into the system, the pressure $\mathrm{P}$ and the flow 


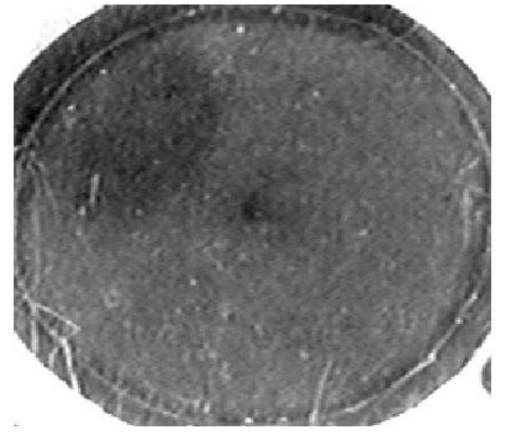

(a) Before percolation, 0 seconds

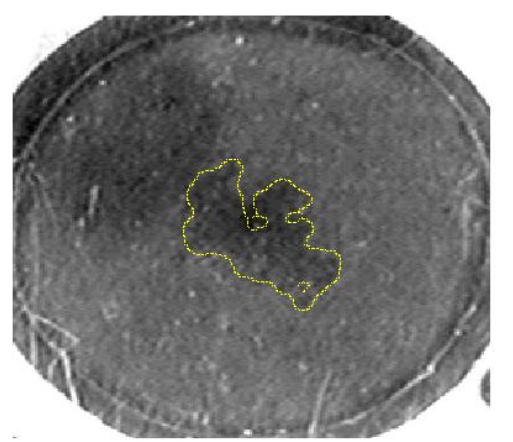

(c) 2010 seconds

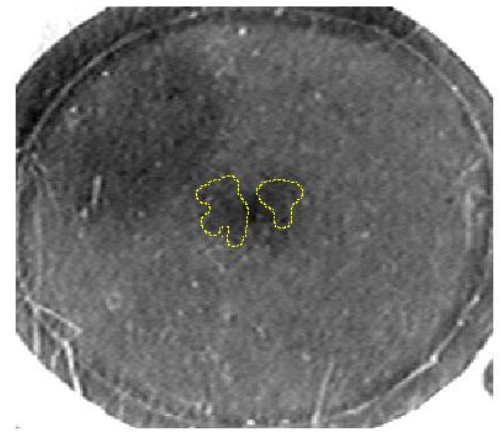

(b) 990 seconds

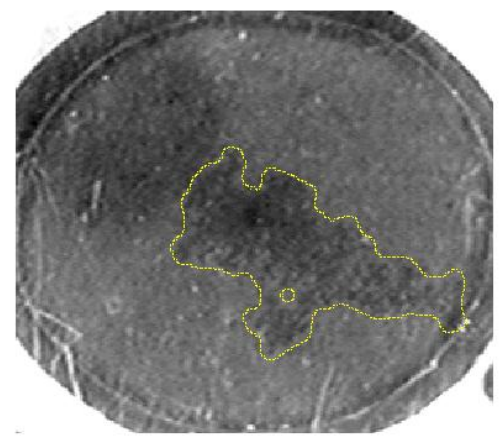

(d) End of test, 3330 seconds

Figure 4.1. Capillary Fingering in the Cathode Nonrun Substrate PTL. 


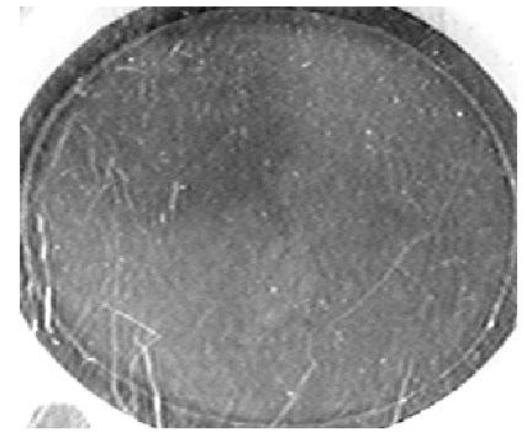

(a) Before percolation, 0 seconds

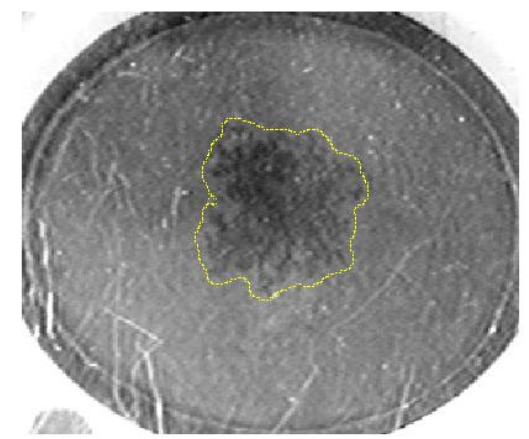

(c) 13.28 seconds

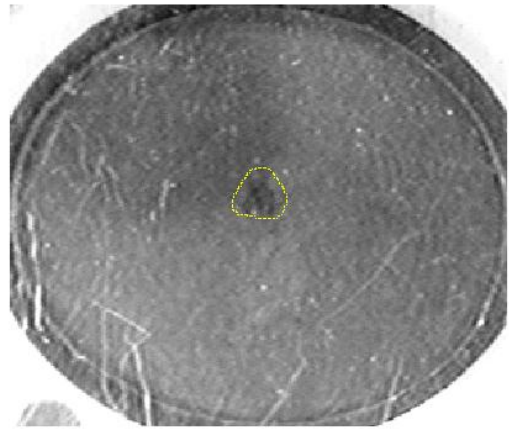

(b) 2.98 seconds

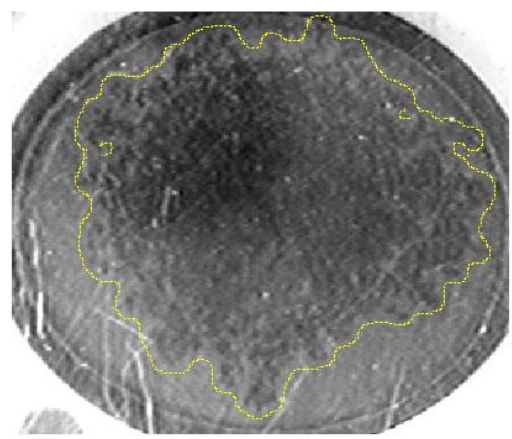

(d) End of test, 27.55 seconds

Figure 4.2. Stable Displacement in the Cathode Nonrun PTL with MPL. 


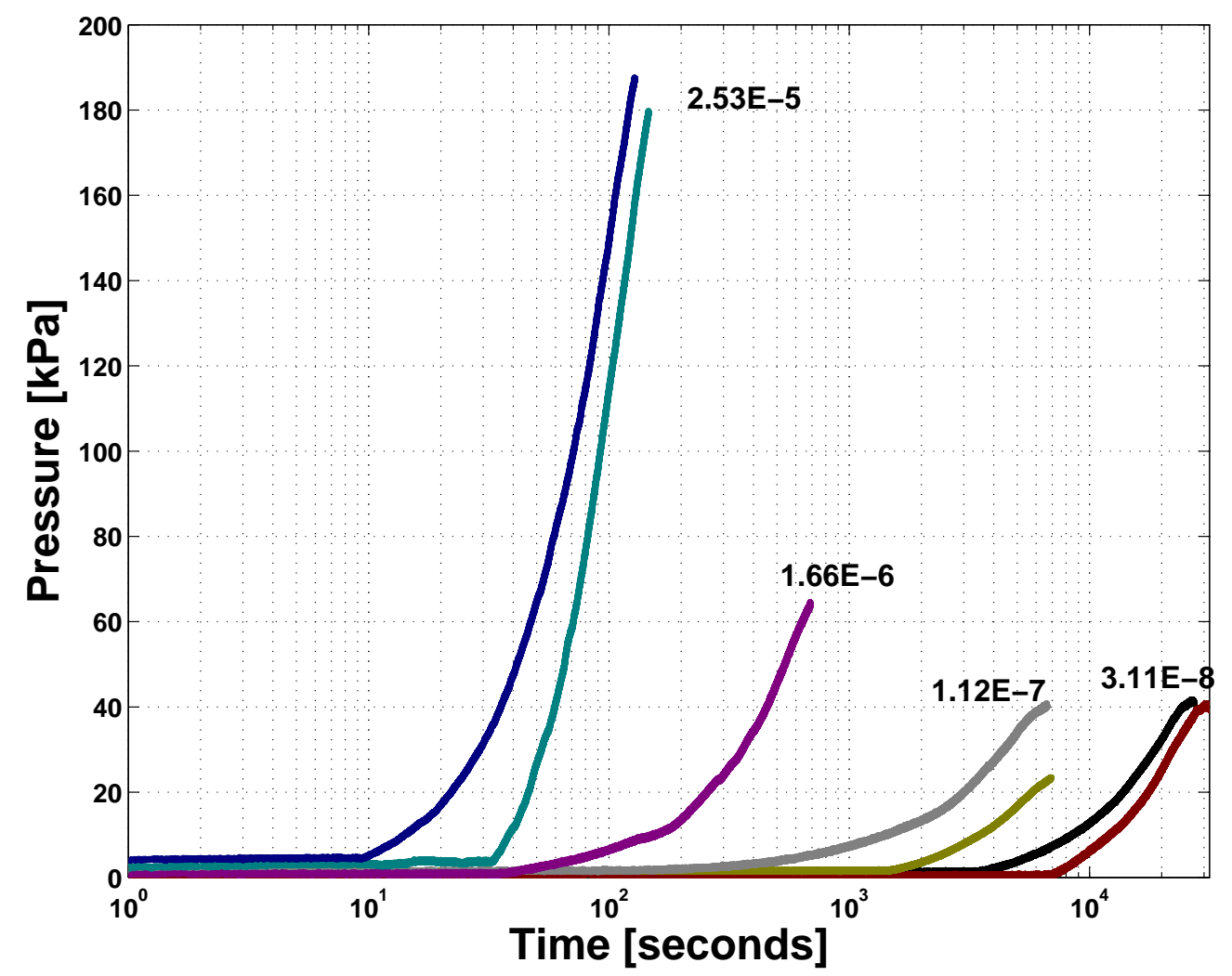

Figure 4.3. Percolation Pressures for the Anode PTL of aged MEA. The capillary numbers for the corresponding test are shown. 
Table 4.1. Percolation pressures of the samples listed, measured in $\mathrm{kPa}$, according to the different flow rates being tested against. The SD in the far right column correspond with Stable Displacement in which percolation pressure does not plateau.

\begin{tabular}{|c||c|c|c|c|}
\hline \multicolumn{1}{|c||}{ Sample } & \multicolumn{4}{c|}{ Capillary Number } \\
\cline { 2 - 5 } & $3.11 \mathrm{E}-8$ & $1.12 \mathrm{E}-7$ & $1.66 \mathrm{E}-6$ & $2.53 \mathrm{E}-5$ \\
\hline Anode-PTL-Non-run & 28 & 43.85 & 73.5 & SD \\
Anode-Aged & $18.4-40$ & $23-40$ & 65.75 & SD \\
\hline \multirow{2}{*}{ Sample } & \multicolumn{4}{|c|}{ Capillary Number } \\
\cline { 2 - 5 } & $3.77 \mathrm{E}-8$ & $1.5 \mathrm{E}-7$ & $5.51 \mathrm{E}-6$ & $2.66 \mathrm{E}-5$ \\
\hline Cathode-PTL-Non-run Sample 2 & 10.5 & 11 & $15.3-22.5$ & SD \\
Anode-Conditioned & $17.5-21$ & $20.5-23.8$ & $43.6-46$ & SD \\
Cathode-Conditioned & 10 & 11.5 & $14.8-17.4$ & SD \\
Cathode-Aged & $10-11.5$ & 11.5 & 14 & SD \\
\hline Sample & \multicolumn{4}{|c|}{ Capillary Number } \\
\cline { 2 - 5 } & $3.77 \mathrm{E}-8$ & $1.5 \mathrm{E}-7$ & $5.51 \mathrm{E}-6$ & $3.87 \mathrm{E}-5$ \\
\hline Cathode-PTL-Non-run Sample 1 & 11.25 & 11.5 & 15 & SD \\
Cathode-Substrate-Non-run & 11 & 12 & 16.4 & SD \\
\hline
\end{tabular}

rate $\mathrm{Q}$, to the energy that is exhausted due to viscous stresses and energy used to generate the interfacial area, corresponding to $\mathrm{Q}^{2} \mu \mathrm{l} / \mathrm{h}^{4}$ where $\mu$ is the viscosity of the injected fluid, 1 is the large length scale, and $\mathrm{h}$ the small length scale. [9] Equation 4.1 shows a scaling for the wetted area of the interface between the non-wetting and wetting surfaces. The advantage of this scaling is the Ce takes into account the pressure and wetted area which are usually treated separately. The $\mathrm{t}^{*}$ is a nondimensional time that represents the injection rate and inverse of capillary number both over the large length scale which is the size of the sample. Medici and Allen [9] showed Ce-t ${ }^{*}$ plots for Toray, MRC, and Freudenberg follow a slope of 1 along a log-log plot, to follow the Ce ratio of all the input energy going in should be coming out.

$$
\begin{aligned}
\mathrm{Ce} & =\frac{P h^{3}}{Q \mu} \frac{A}{l^{2}} \\
t^{*} & =t \frac{P h^{2}}{l^{3} \mu}
\end{aligned}
$$

From the PTL data collected using the pseudo Hele-Shaw experimental setup, samples were characterized according to non-run, conditioned and aged PTLs of either cathode or anode, to detect the changes of the structure due to aging. Using the Ce$\mathrm{t}^{*}$, plots were created as shown in Figure 4.4. The comlete set of the Ce- ${ }^{*}$ plots are included in Appendix D. The Ce- $t^{*}$ traces do not follow a slope of 1 . However, the Ce traces for each test show an unusual behavior in which there is an initial slope of 1 and then the slope increases indicating that energy is being stored in the porous 


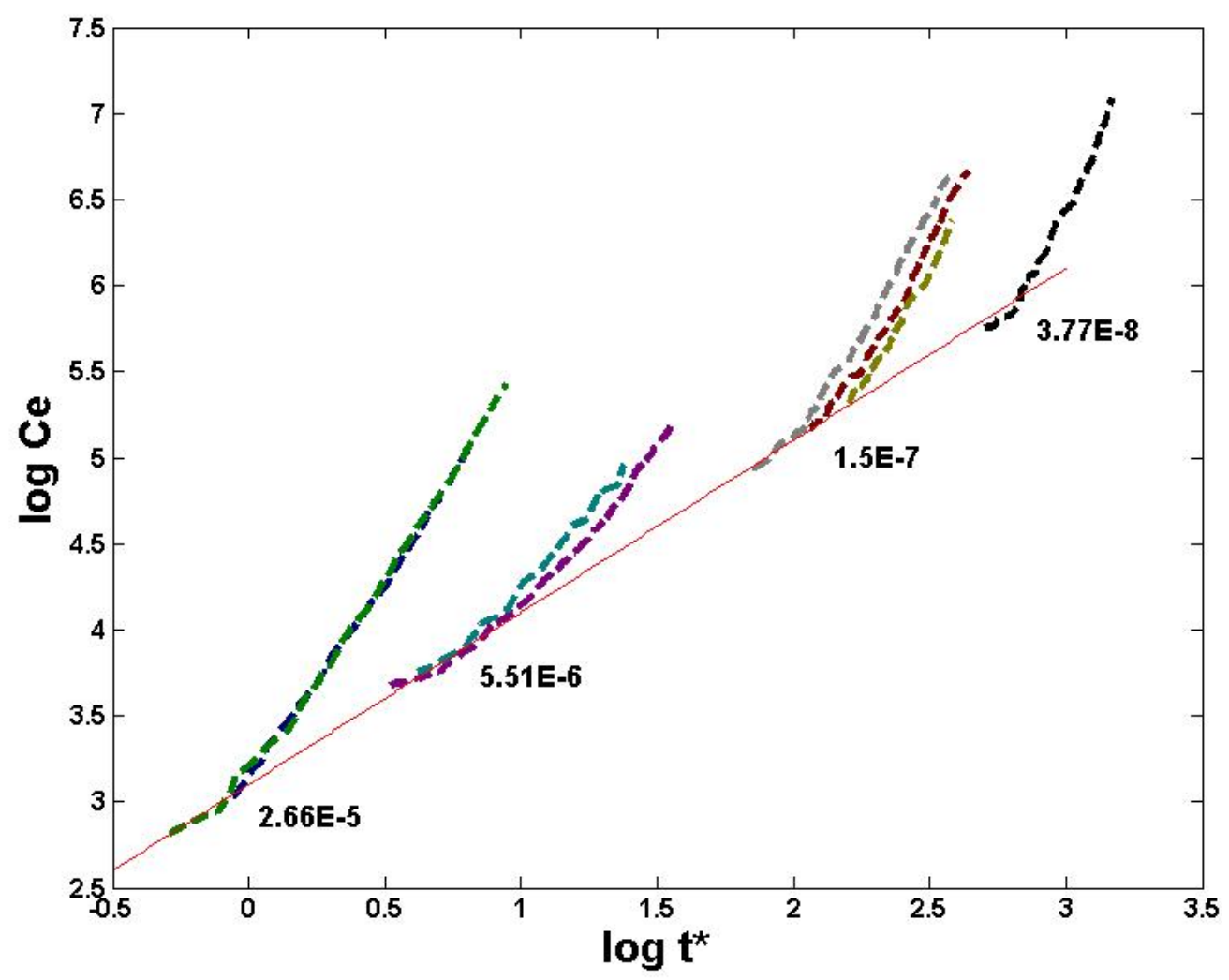

Figure 4.4. Ce plot for the Anode PTL that has been conditioned. The capillary numbers for each line can be seen in the legend. The solid line has been put in as a fit to the Ce lines with a slope of one on the log-log plot.

media. This is showing a compression of air occurring in the samples, which gets trapped in dead end pores or small throats. This compression or energy storage will give rise to a higher magnitude of Ce which in turn results in a larger slope.

A comparison of the initial Ce-t* trace for each sample is shown in Figures 4.5.4.7. The comparison of the non-run cathode substrate to PTL with MPL in Figure 4.5 does not show a large transition between the samples. The minor change between slopes of the samples could be a due to a difference in wettability characteristics and morphology. However the change is so small that this is likely due to image processing.

The cathode non-run PTL with MPL, conditioned and aged samples are shown in Figure 4.6. The conditioned samples did not change much in $\mathrm{Ce}$ as compared to the non-run samples. The aged samples, however, changed significantly with a lower Ce-t trace, which indicates that the cathode PTL increased in permeability. 


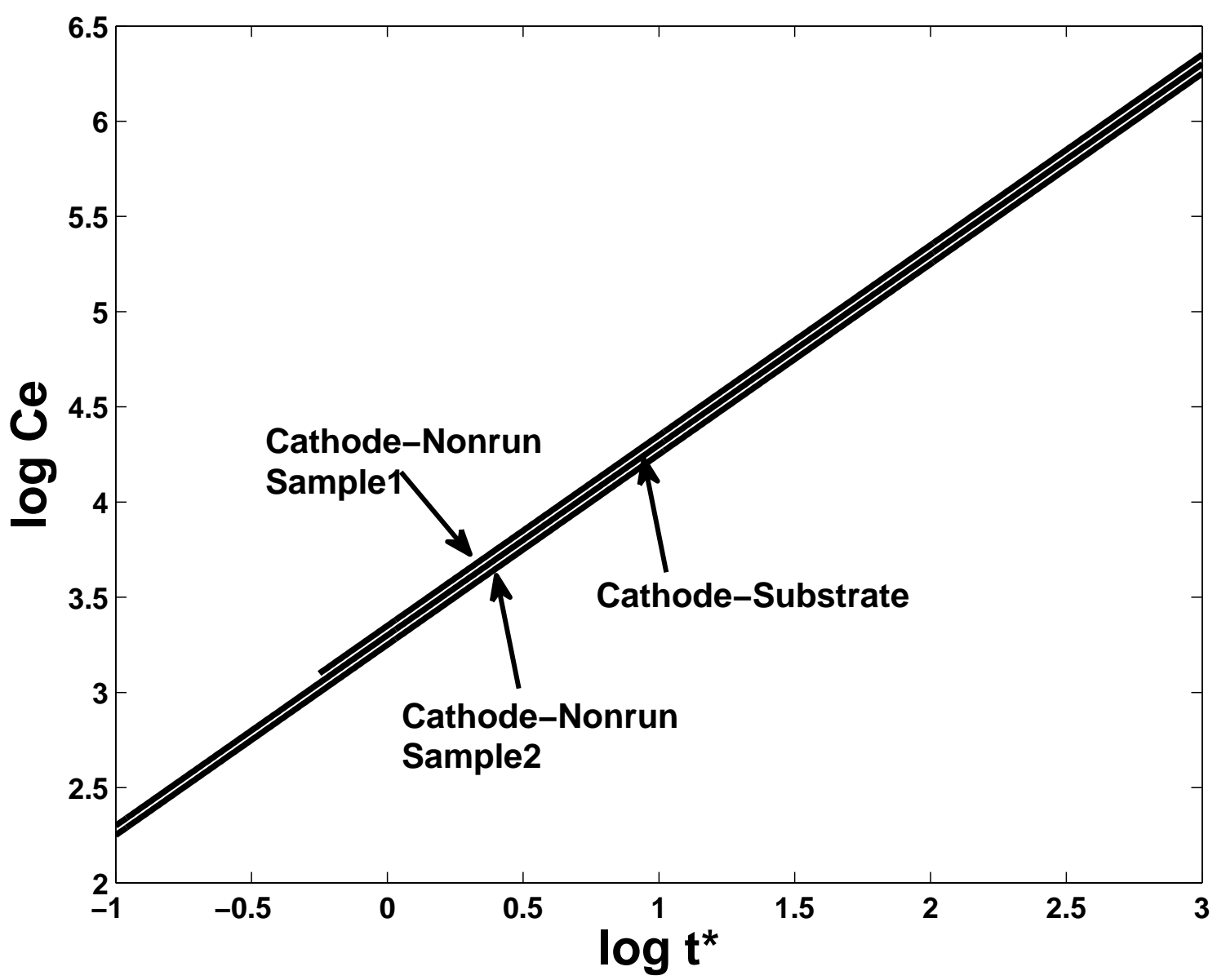

Figure 4.5. Ce comparison for Non-Run Substrate, PTL with MPL sample 1, and PTL with MPL sample 2 for the cathode samples.

The last comparison was that of the anode non-run PTL with MPL, anode conditioned and anode aged samples shown in Figure 4.7. This was similar to the cathode comparison however the aged sample was changed in the opposite direction. In contrast to the cathode PTL, the change in Ce indicates that the anode PTL became less permeable during aging. As of now, the reason for these changes is not identified. 


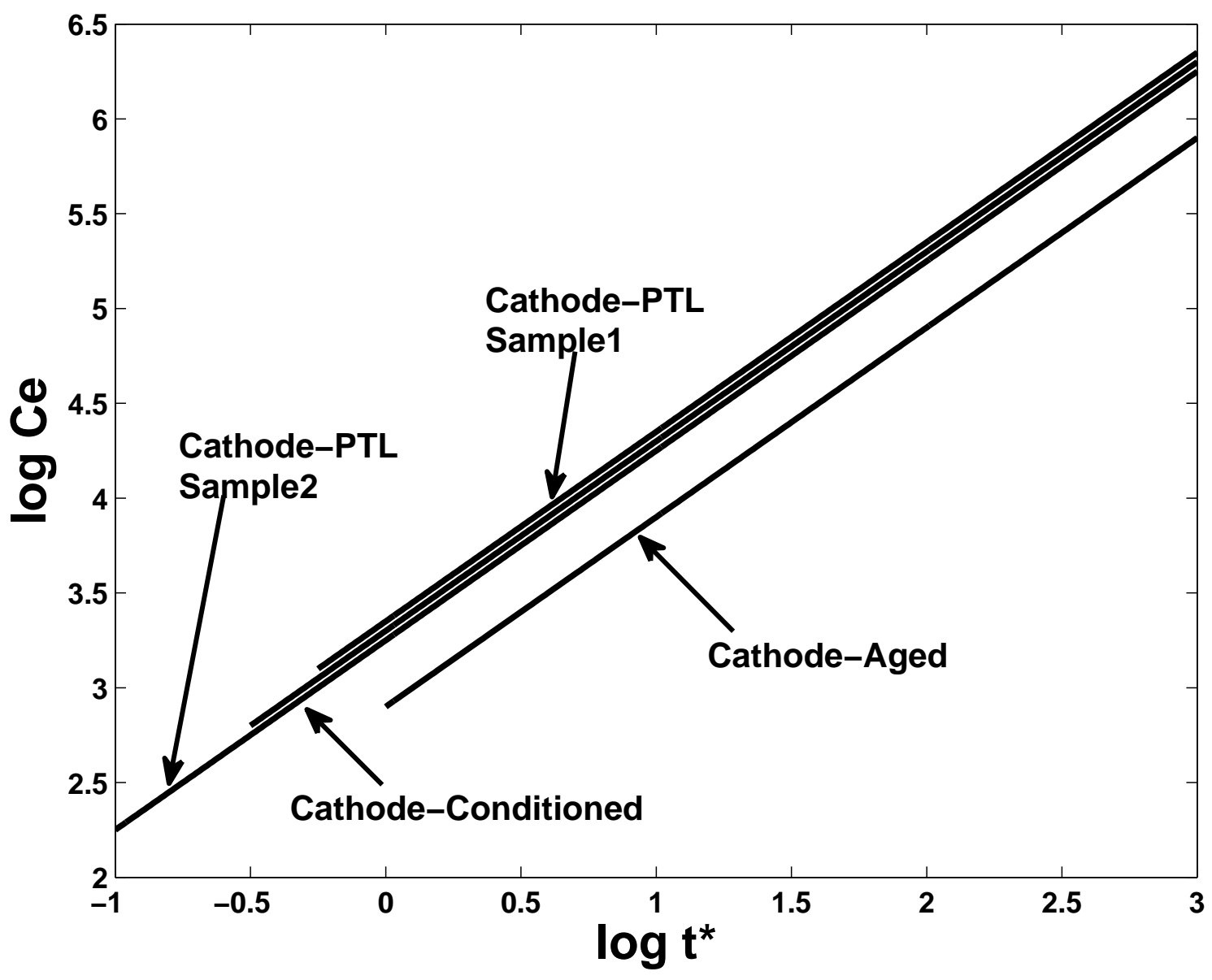

Figure 4.6. Ce comparison for Non-run PTL with MPL sample 1, and Non-Run PTL with MPL sample 2, Conditioned, and Aged for the cathode samples. 


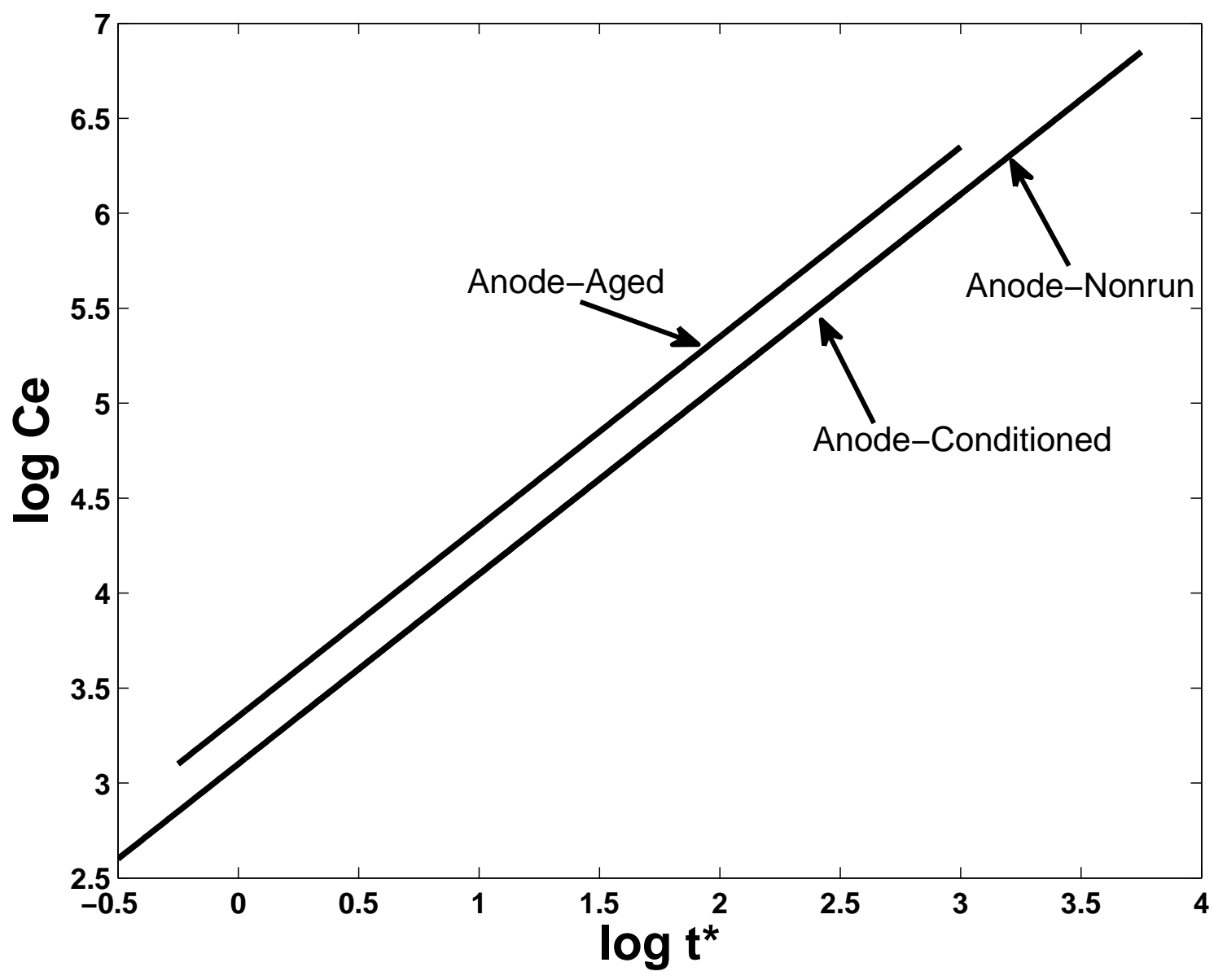

Figure 4.7. Ce comparison for Non-run sample, Conditioned, and Aged for the anode samples. 


\section{Catalyst Layer Characterization}

The main goal of the Catalyst Layer Percolation Experimenting was to detect structural changes in the catalyst layer due to aging. The structure of the Catalyst Layer in Proton Exchange Membrane Fuel Cells is much different than that of the PTL. To start with the chemical makeup of the Catalyst Layer that is being used for this study is made up of Ionomer, Carbon particles, and Platinum nanoparticles.

Most of the research shows a similar structure for carbon based catalyst layer. The structure of the Catalyst Layer is comprised of micro-structures called agglomerates. Agglomerates are groups of carbon particles which are deposited with platinum nanoparticles. These agglomerates are then suspended in the ionomer to create pores known as secondary pores. Eikerling [3] described the structure of the catalyst layer in a PEM fuel cell to have ionomer strands built into the agglomerates. Eikerling [3] explains, having the ionomer strands in the agglomerate will help with the transfer of reactants to the catalyst sites.

The thickness and pore size of the catalyst layer may vary depending upon the fabrication method. The thickness of the catalyst layer is generally between 10$20 \mu \mathrm{m}$. [2, 3, 16] The pore size within the catalyst layer is not well established and can vary significantly. Uchida et al. [16] showed the secondary pore size, pores between agglomerates, to have diameters of $0.04-1 \mu \mathrm{m}$. Other researchers have shown secondary pore sizes from 10-200 nm. [2, 3]

\subsection{Process 1 and Process 2 Results}

The flow regime observed during imbibition is stable displacement as defined by Lenormand et al. [17. The stable displacement can be seen in detail in Figure 5.1. The pressure plots for Process 1 are shown in Figure 5.2, with noise in the line made from the test equipment. Three different flow rates were tested on the sample, while keeping the sample compression constant. Two separate sets of tests were done for one parameter on the Process 1 catalyst layers, showing excellent repeatability. As the fluid is entering the channel the pressure is relatively constant. Once the liquid reaches the catalyst layer interface, a pressure rise occurs. A trend in increasing pressure with increasing flow rate can be seen in the plots in Appendix E. As the flow 


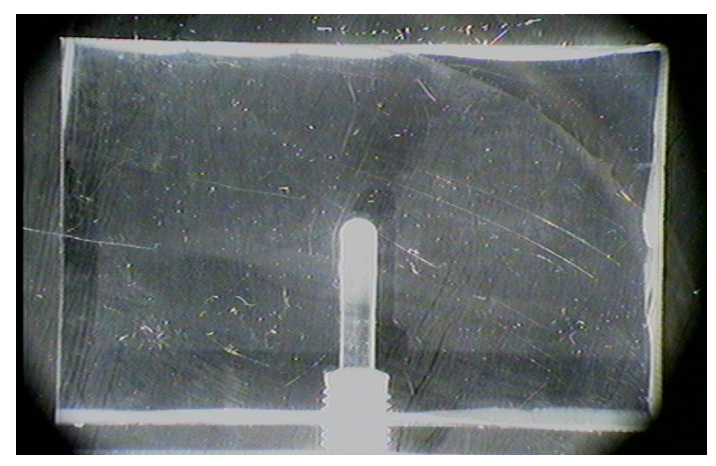

(a) Before percolation, 0 seconds

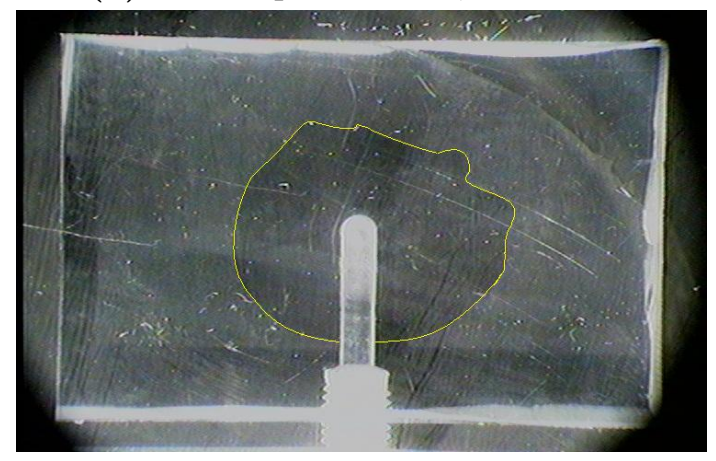

(c) 1.77 seconds

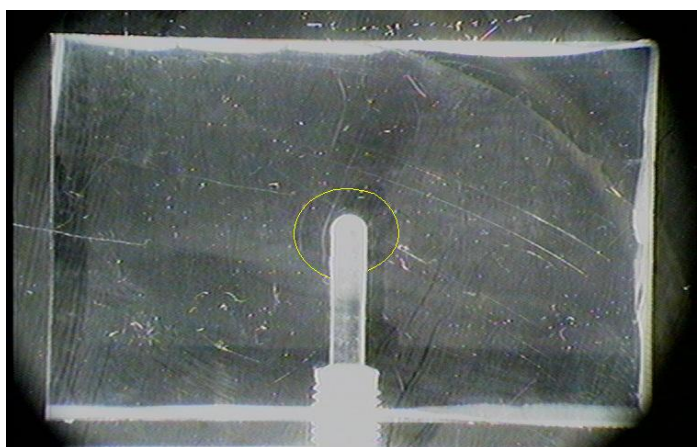

(b) 0.22 seconds

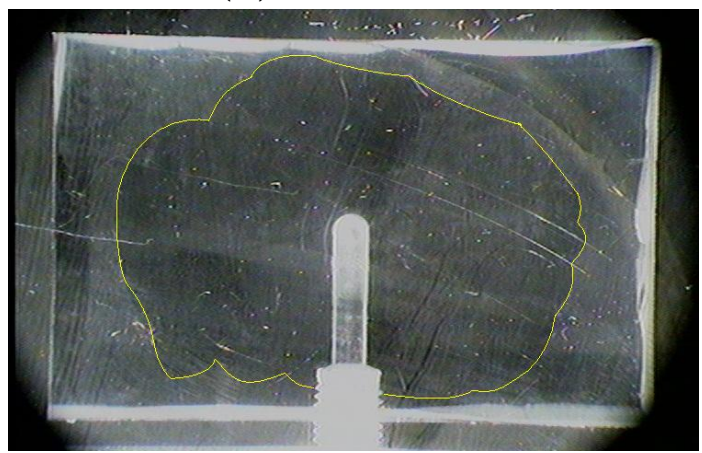

(d) End of test, 3.66 seconds

Figure 5.1. Percolation in Process 1 of catalyst layers. 


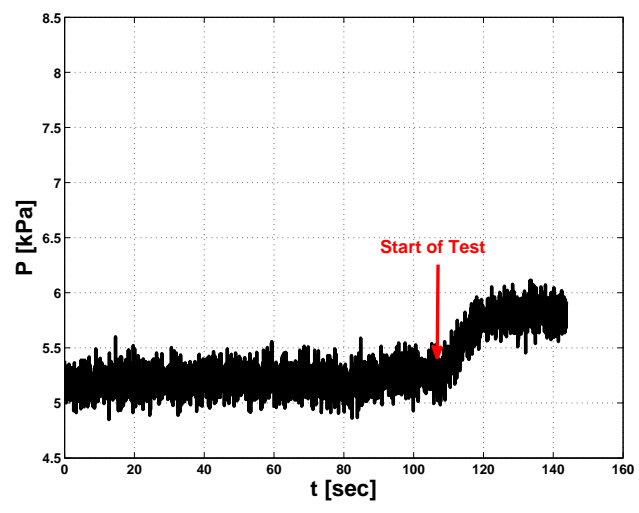

(a) $41.37 \mathrm{kPa}$ Compression

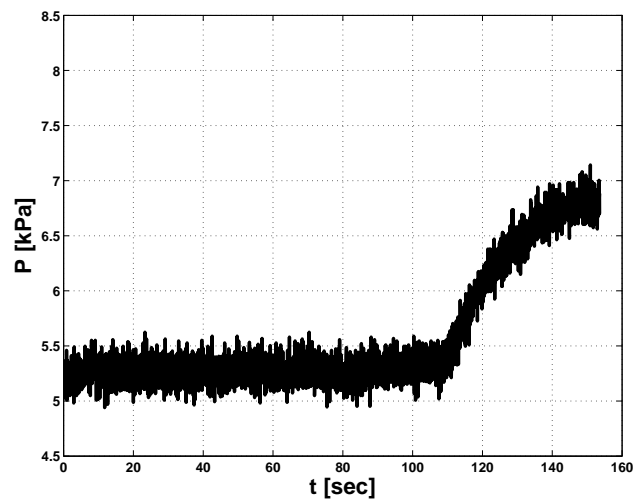

(c) $82.74 \mathrm{kPa}$ Compression

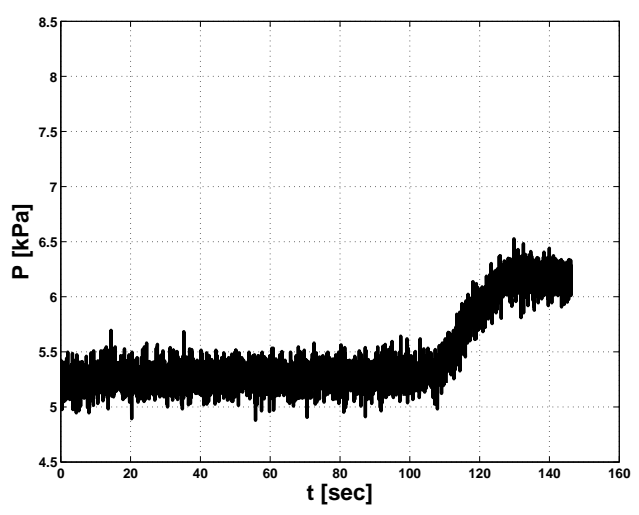

(b) $55.16 \mathrm{kPa}$ Compression

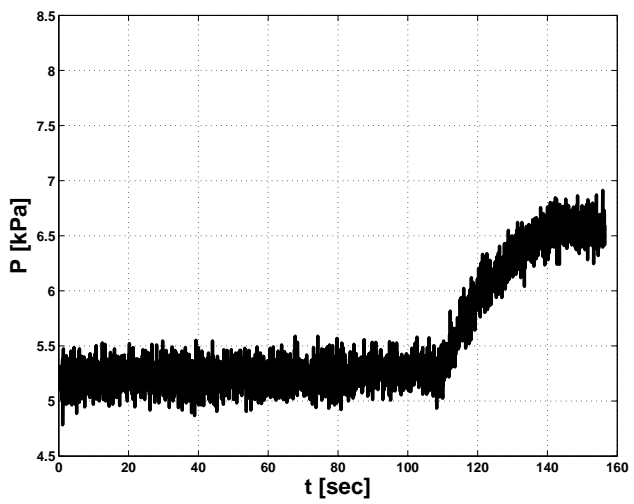

(d) $96.53 \mathrm{kPa}$ Compression

Figure 5.2. Percolation pressure plot of Process 1. The tests were conducted at three different compressions on the sample $41.37 \mathrm{kPa}, 55.16 \mathrm{kPa}, 82.74 \mathrm{kPa}$, $96.53 \mathrm{kPa}$ while holding the flow rate constant at $9.48 \mathrm{E}-4 \mathrm{mLs}^{-1}$. 


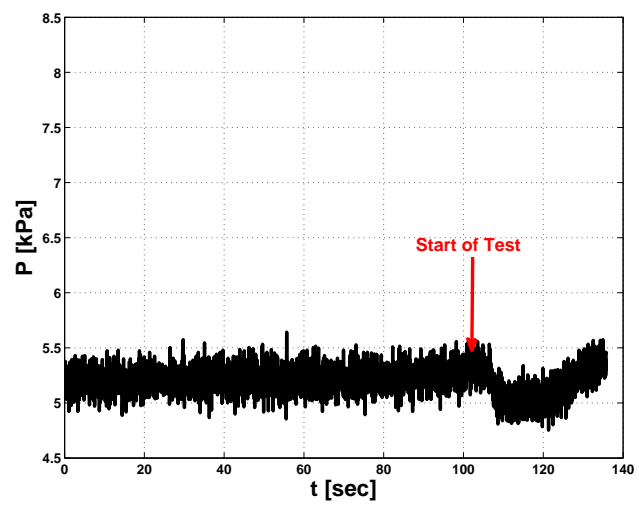

(a) $41.37 \mathrm{kPa}$ Compression

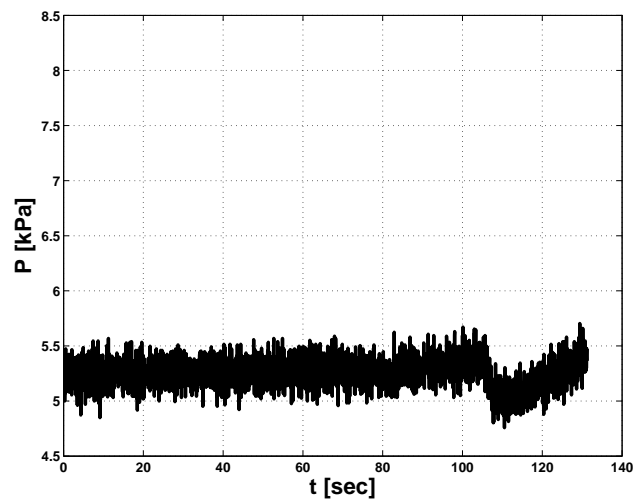

(c) $82.74 \mathrm{kPa}$ Compression

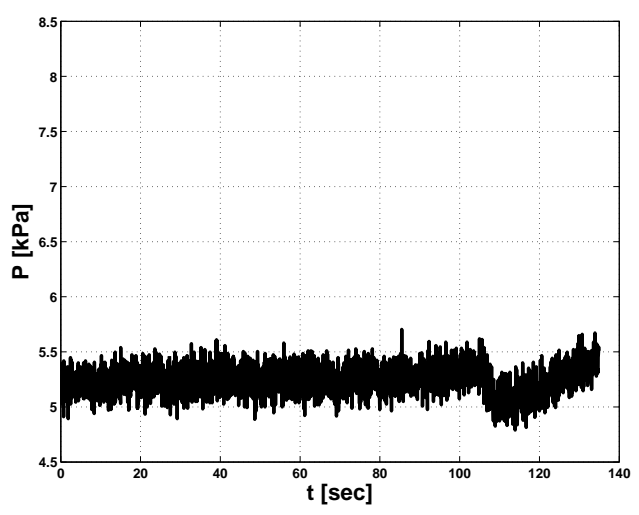

(b) $55.16 \mathrm{kPa}$ Compression

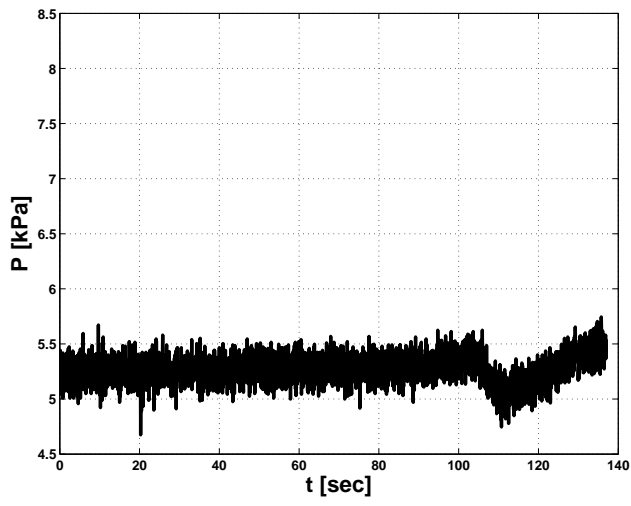

(d) $96.53 \mathrm{kPa}$ Compression

Figure 5.3. Percolation pressure plot of Process 2. The tests were conducted at three different compressions on the sample $41.37 \mathrm{kPa}, 55.16 \mathrm{kPa}, 82.74 \mathrm{kPa}$, $96.53 \mathrm{kPa}$ while holding the flow rate constant at $9.48 \mathrm{E}-4 \mathrm{mLs}^{-1}$. 
rate increases by a factor of two results there are no significant changes in the pressure increase or decrease. The pressure difference for the $9.84 \mathrm{E}-4$ and $18.75 \mathrm{E}-4 \mathrm{mLs}^{-1}$ tests show similar differences of roughly $0.6 \mathrm{kPa}$ for a compression $41.37 \mathrm{kPa}, 0.9 \mathrm{kPa}$ for a $55.16 \mathrm{kPa}$ compression, $1.4-1.5 \mathrm{kPa}$ for a $82.74 \mathrm{kPa}$ compression and $1.5-1.6 \mathrm{kPa}$ for a $96.53 \mathrm{kPa}$ compression. When a second increase in flow rate by a factor of 2 occurs there is a noticeable doubling of pressure rise, with the pressure difference values of $1 \mathrm{kPa}$ for a compression $41.37 \mathrm{kPa}, 1.5 \mathrm{kPa}$ for a $55.16 \mathrm{kPa}$ compression, $2.7 \mathrm{kPa}$ for a $82.74 \mathrm{kPa}$ compression and $3 \mathrm{kPa}$ for a $96.53 \mathrm{kPa}$ compression for $37.08 \mathrm{E}-4 \mathrm{mLs}^{-1}$.

The testing for Process 2 was similar to the Process 1 . The percolation pressure plots for Process 2 can be seen in Figure fig:ProcessM. The plots show that Process 2 had a small drop in pressure at the onset of percolation in every test. The FC3283 wicks into the catalyst layer creating a negative pressure at the beginning of imbibition. The pressure starts to increase after the liquid has wicked into all available pores and is then being displaced throughout the catalyst layer by the syringe pump. The percolation pressure is not as high in Process 2 as Process 1, and the increase in percolation pressure with increasing flow rate is not observed in Process 2. The drop in pressure becomes less pronounced as the flow rate is increased.

\section{$5.2 \quad$ Full CCM Results}

The full CCM samples that were tested using the modified pseudo Hele-Shaw setup included cathode catalyst layer samples that were non-run, conditioned, and aged under different conditions. In Tables 5.1 and 5.2 are the properties of the different samples that were tested for this study, which were supplied by Ballard Power Systems.

Table 5.1. List of Non-Run Catalyst Layer samples with properties.

\begin{tabular}{|c|c|c|c|c|}
\hline Sample Name & Ionomer \% & Platinum Loading $\mathrm{mgPt} / \mathrm{cm}^{2}$ & Porosity & Thickness \\
\hline VD420 & $12 \%$ & 0.4 & $81 \%$ & $16.4 \mu \mathrm{m}$ \\
VD421 & $30 \%$ & 0.4 & $60 \%$ & $11.7 \mu \mathrm{m}$ \\
VD422 & $23 \%$ & 0.4 & $70 \%$ & $13.4 \mu \mathrm{m}$ \\
VD423 & $50 \%$ & 0.4 & $35 \%$ & $11.6 \mu \mathrm{m}$ \\
VD424 & $23 \%$ & 0.2 & $66 \%$ & $5.6 \mu \mathrm{m}$ \\
VD425 & $23 \%$ & 0.5 & $73 \%$ & $18.3 \mu \mathrm{m}$ \\
\hline
\end{tabular}

The results of the Percolation testing on Full CCM Catalyst Layer Samples are shown in Figure 5.4. Testing results for the other samples are included in the Appendix $\mathrm{F}$. These plots designate the beginning of the test (BOT) and the end of the test (EOT) on the plot. The EOT was determined by the saturation reaching the edge of the platen. The Percolation Pressure plots show three different compressions, $41.73,68.95$, and $96.53 \mathrm{kPa}$, with two tests done at each. There were a total of three 
Table 5.2. List of Aged and Conditioned Catalyst Layer samples with properties.

\begin{tabular}{|c|c|c|c|}
\hline Sample Name & Aged or Conditioned & Porosity & Thickness \\
\hline VD432 & $1 \mathrm{~V}$ & $67 \%$ & $11 \mu \mathrm{m}$ \\
VD436 & $1.3 \mathrm{~V}$ & $39 \%$ & $3.3 \mu \mathrm{m}$ \\
VD328 & $1.4 \mathrm{~V}$ & $36 \%$ & $3.1 \mu \mathrm{m}$ \\
VD302 & Conditioned & $68 \%$ & $12 \mu \mathrm{m}$ \\
\hline
\end{tabular}

flow rates used, $9.48 \mathrm{E}-4,18.75 \mathrm{E}-4$, and $37.08 \mathrm{E}-4 \mathrm{mLs}^{-1}$. Table 5.3 shows the results from testing sample VD423. There were tests done at three separate flow rates with three compressions at each flow rate. At these settings there were two tests done to which the data was found to be very repetitive, as can be seen for sample VD423 in Table 5.3. Tables of results for the rest of the samples can be seen in Appendix $\mathrm{G}$. The way repetitiveness was looked at was by taking the difference in pressure from the start of the test to the end of the test over the difference in time giving a slope, which was plotted in Figure 5.55.6 according to the compression and the flow rate of the test. These plots represent the nonrun samples in Figure 5.5 and the conditioned and aged samples in Figure 5.6. Both plots show the samples have a trend occurring amongst the increase in flow rate with no noticeable change amongst the compression. There is a very noticeable difference amongst each sample at higher flow rates rather than the lower flow rates. 


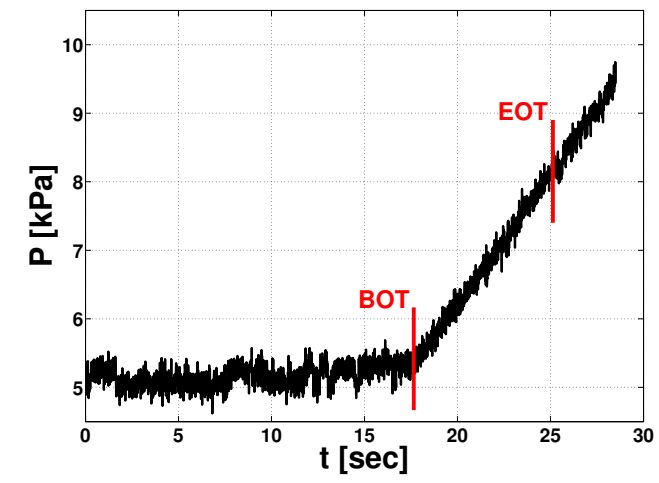

(a) $1^{\text {st }}$ test at $41.37 \mathrm{kPa}$.

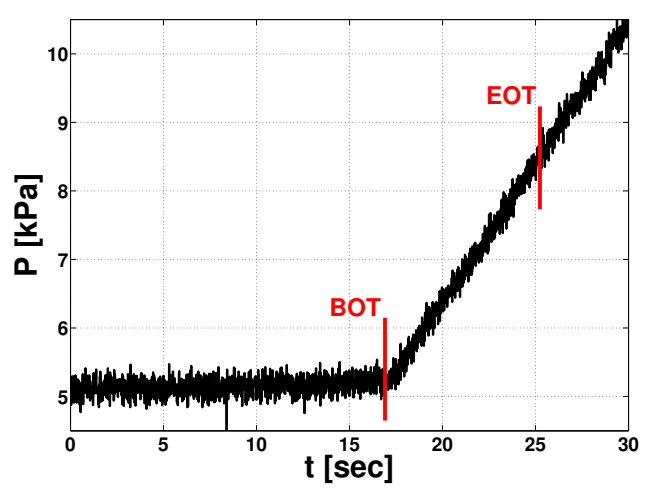

(c) $1^{\text {st }}$ test at $68.95 \mathrm{kPa}$.

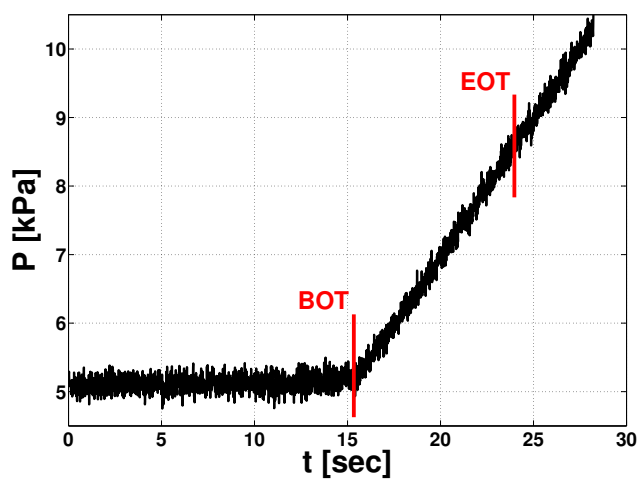

(e) $1^{\text {st }}$ test at $96.53 \mathrm{kPa}$.

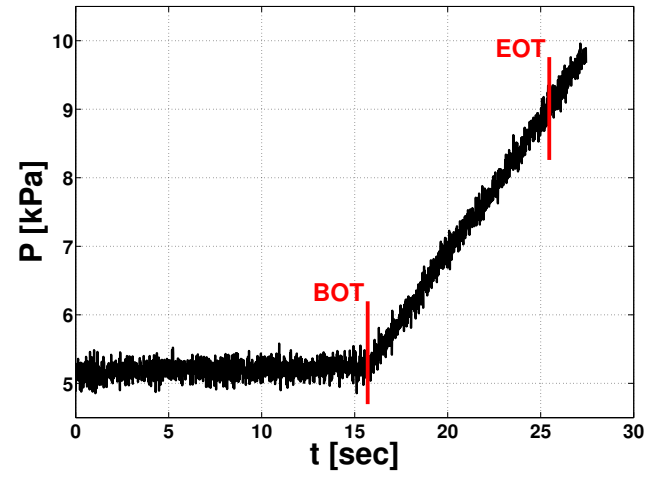

(b) $2^{\text {nd }}$ test at $41.37 \mathrm{kPa}$.

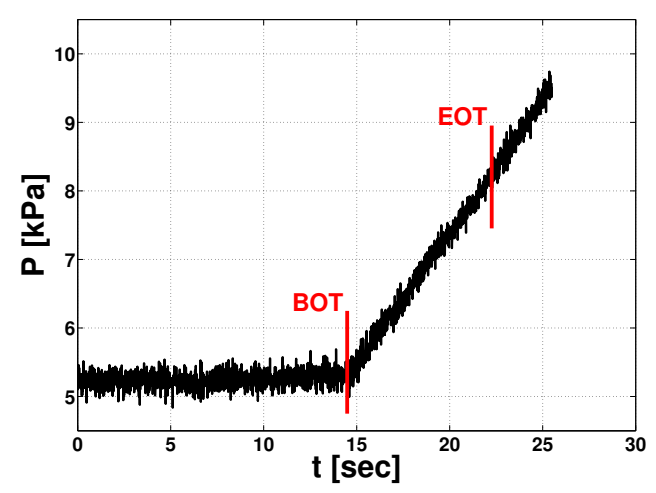

(d) $2^{\text {nd }}$ test at $68.95 \mathrm{kPa}$.

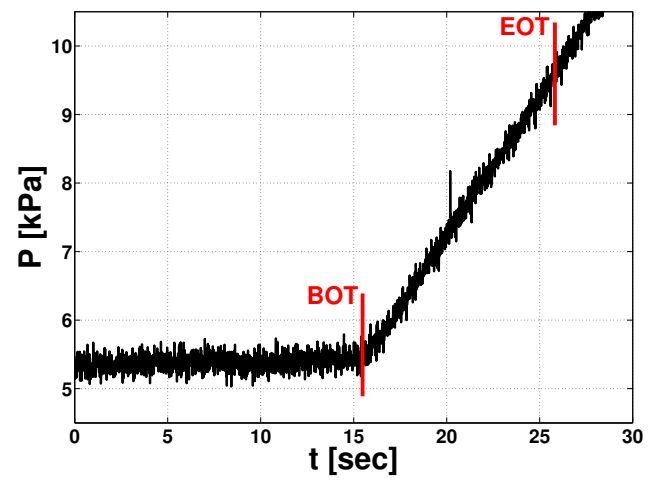

(f) $2^{\text {nd }}$ test at $96.53 \mathrm{kPa}$.

Figure 5.4. Percolation pressure plot of full CCM sample VD423. The tests were conducted at three different compressions on the sample $41.37 \mathrm{kPa}, 68.95 \mathrm{kPa}$, $96.53 \mathrm{kPa}$ while holding the flow rate constant at $37.08 \mathrm{E}-4 \mathrm{mLs}^{-1}$. 
Table 5.3. Summary of the full CCM sample VD423 Percolation Pressure testing results. The BOT and EOT labeled here are to denote the beginning of the test and end of the test. The slope is taken as the pressure difference over the time difference from the BOT to the EOT.

\begin{tabular}{|l|l|l|l|l|l|l|l|c|}
\hline $\begin{array}{l}\text { Pump } \\
\text { Speed } \\
\left(\mathrm{mLs}^{-1}\right)\end{array}$ & $\begin{array}{l}\text { Compression } \\
(\mathrm{kPa})\end{array}$ & $\begin{array}{l}\text { BOT } \\
(\mathrm{s})\end{array}$ & $\begin{array}{l}\text { BOT } \\
(\mathrm{kPa})\end{array}$ & EOT(s) $)$ & $\begin{array}{l}\text { EOT } \\
(\mathrm{kPa})\end{array}$ & $\begin{array}{l}\text { Time } \\
\text { Diff }(\mathrm{s})\end{array}$ & $\begin{array}{l}\text { Press } \\
\text { Diff } \\
(\mathrm{kPa})\end{array}$ & Slope \\
\hline & 41.37 & 17.65 & 5.17 & 25.13 & 8.15 & 7.48 & 2.99 & 0.4 \\
$37.08 \mathrm{E}-4$ & 41.37 & 15.7 & 5.2 & 25.4 & 9.01 & 9.76 & 3.81 & 0.39 \\
& 68.95 & 16.91 & 5.15 & 25.24 & 8.48 & 8.33 & 3.33 & 0.4 \\
& 68.95 & 14.49 & 5.25 & 22.26 & 8.2 & 7.77 & 2.95 & 0.38 \\
& 96.53 & 15.34 & 5.13 & 23.97 & 8.59 & 8.63 & 3.46 & 0.4 \\
& 96.53 & 15.48 & 5.39 & 25.82 & 9.59 & 10.34 & 4.2 & 0.41 \\
\hline & 41.37 & 35.02 & 5.19 & 46.8 & 7.42 & 11.78 & 2.23 & 0.19 \\
& 41.37 & 32.46 & 5.06 & 44.36 & 7.07 & 11.9 & 2.02 & 0.17 \\
& 68.95 & 34.52 & 5.03 & 47.64 & 7.6 & 13.12 & 2.58 & 0.2 \\
& 68.95 & 24.64 & 5.08 & 36.52 & 7.36 & 11.88 & 2.29 & 0.19 \\
& 96.53 & 33.58 & 5.02 & 42.08 & 6.72 & 8.5 & 1.7 & 0.2 \\
& 96.53 & 30.06 & 5.1 & 39.98 & 6.81 & 9.92 & 1.71 & 0.17 \\
\hline \multirow{5}{*}{$9.48 \mathrm{E}-4$} & 41.37 & 73.75 & 4.98 & 92.22 & 6.67 & 18.46 & 1.69 & 0.09 \\
& 41.37 & 71.3 & 5.03 & 87.03 & 6.36 & 15.72 & 1.33 & 0.09 \\
& 68.95 & 71.56 & 5.04 & 88.59 & 6.56 & 17.0329 & 1.52 & 0.09 \\
& 68.95 & 37.81 & 5.03 & 53.64 & 6.37 & 15.82 & 1.35 & 0.09 \\
& 96.53 & 70.96 & 4.94 & 84.21 & 6.08 & 13.24 & 1.14 & 0.09 \\
& 96.53 & 71.94 & 5.02 & 88.97 & 6.5 & 17.03 & 1.48 & 0.09 \\
\hline
\end{tabular}




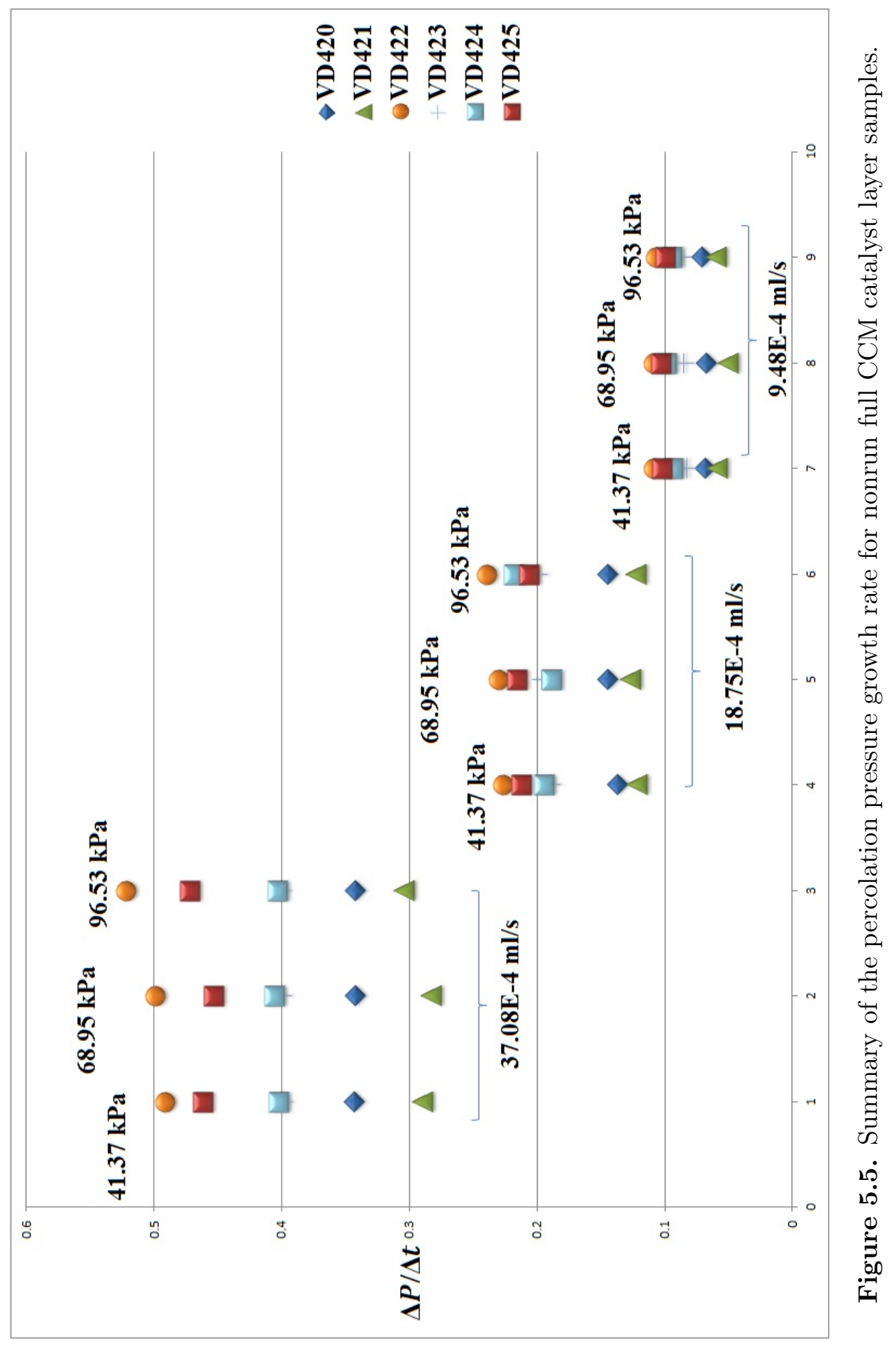




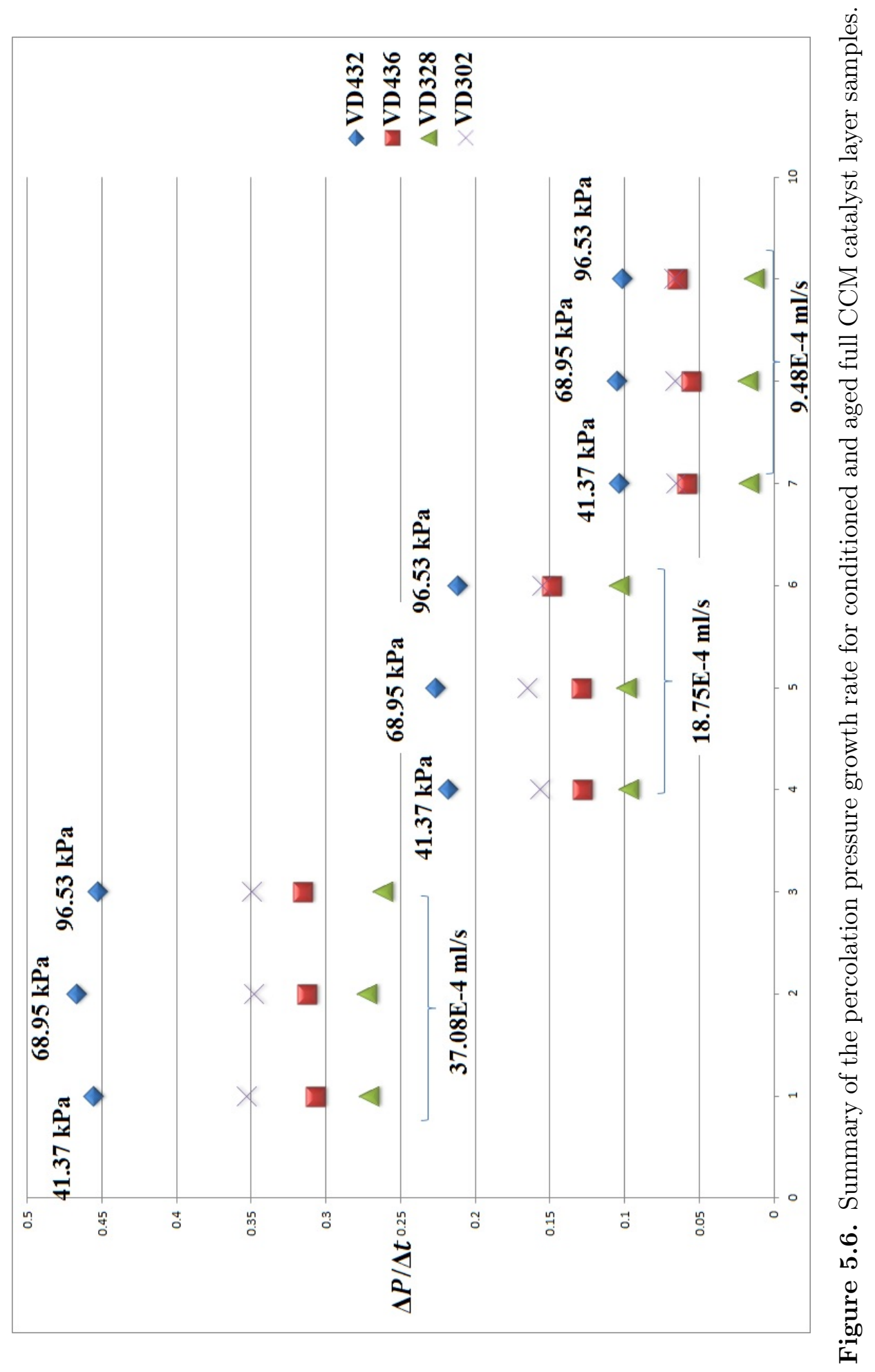


Figure 5.7 shows the Percolation Pressure against Wetted Volume for the sample VD423. The Wetted volume is wetted area times the sample thickness divided by the sample volume and is a measure of saturation. The plots show only data between BOT and the EOT. From this plot it can be shown that the sample does not reach full saturation by the end of the testing.

VD328, aged at $1.4 \mathrm{~V}$, showed an unusual spreading during the testing. This sample contained grooves, roughly $0.8 \mathrm{~mm}$ wide. The spread pattern in VD328 followed these grooves resulting in asymmetric spreading.

Permeability is a measure of how easy the fluid can pass through the media. For porous media in a fuel cell the permeability should be semi-pervious to impervious. [18] Equation 5.1 was used to calculate the permeability in the catalyst layers,

$$
\mathrm{K}=\frac{v \mu \Delta x}{\Delta P}
$$

where $\mathrm{K}$ is the permeability, $v$ is the average velocity of the fluid, and $\mu$ is the viscosity of the fluid. $\Delta \mathrm{x}$ is the radius of the spreading, which was always as stable displacement. $\Delta \mathrm{P}$ is the pressure difference during spreading. If the flow regime had been of capillary fingering or viscous fingering then permeability would be more difficult to determine. Figure 5.8 shows the permeability of a non-run catalyst layer with a $50 \%$ weight percentage of ionomer, 0.4 Platinum loading, $35 \%$ porosity and $11.6 \mu \mathrm{m}$ thickness, with very repeatable data. Plots for the rest of the samples permeabilities can be seen in Appendix J. The plots show the samples as being more semi-pervious than impervious. Considering that this was a wetting fluid the permeability could be effected when using a different fluid. 


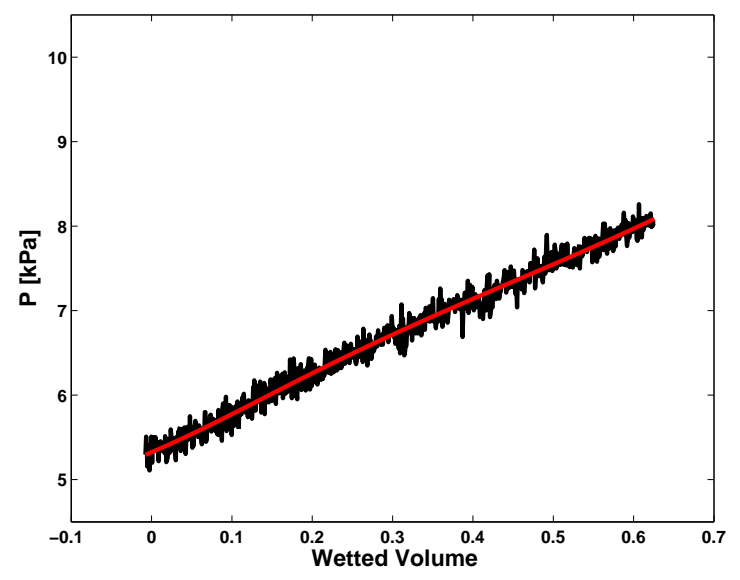

(a) $1^{\text {st }}$ test at $41.37 \mathrm{kPa}$.

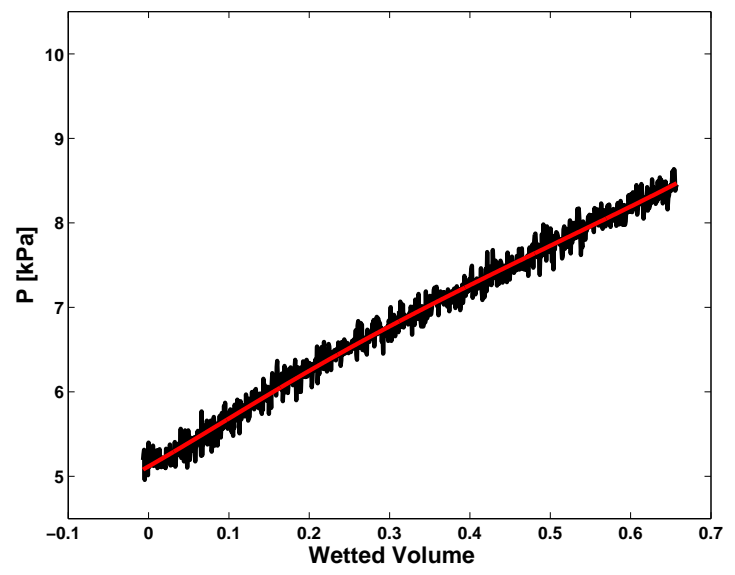

(c) $1^{\text {st }}$ test at $68.95 \mathrm{kPa}$.

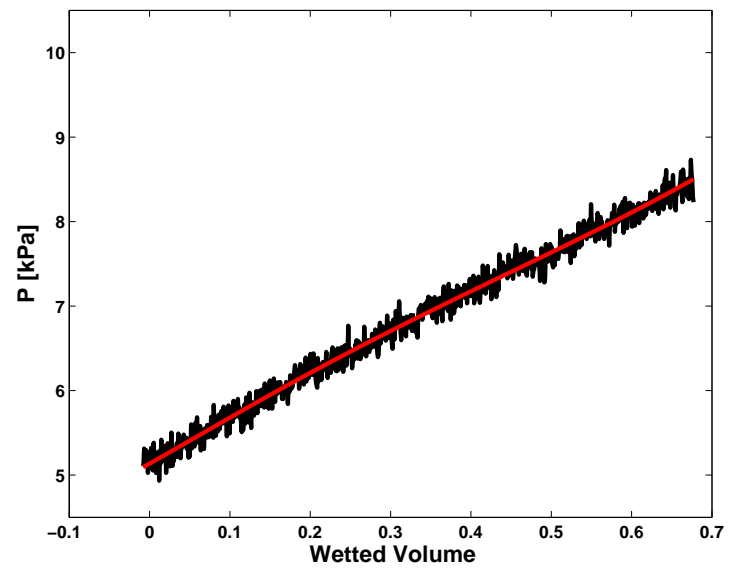

(e) $1^{\text {st }}$ test at $96.53 \mathrm{kPa}$.

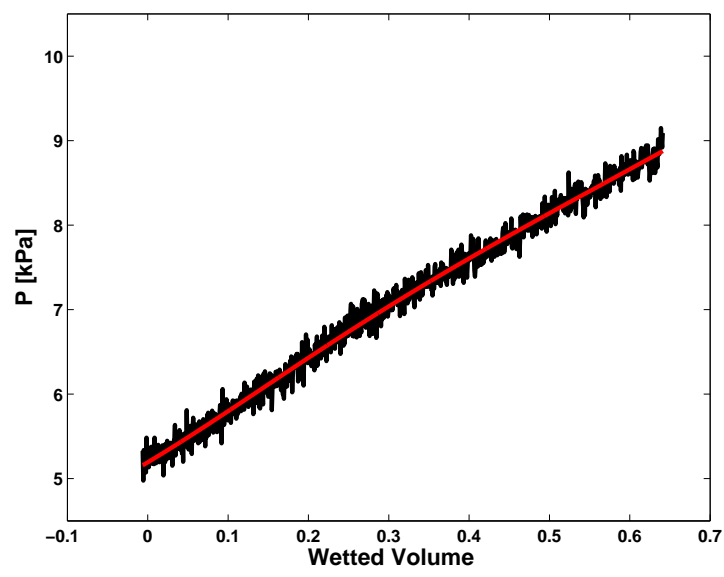

(b) $2^{\text {nd }}$ test at $41.37 \mathrm{kPa}$.

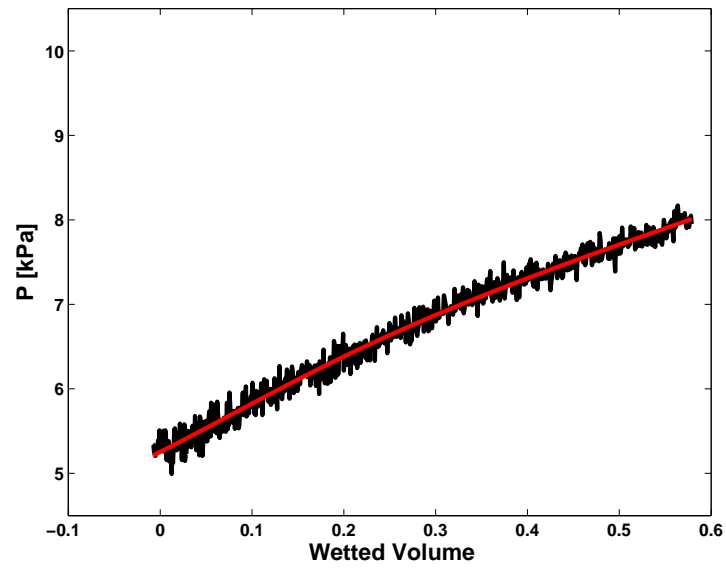

(d) $2^{\text {nd }}$ test at $68.95 \mathrm{kPa}$.

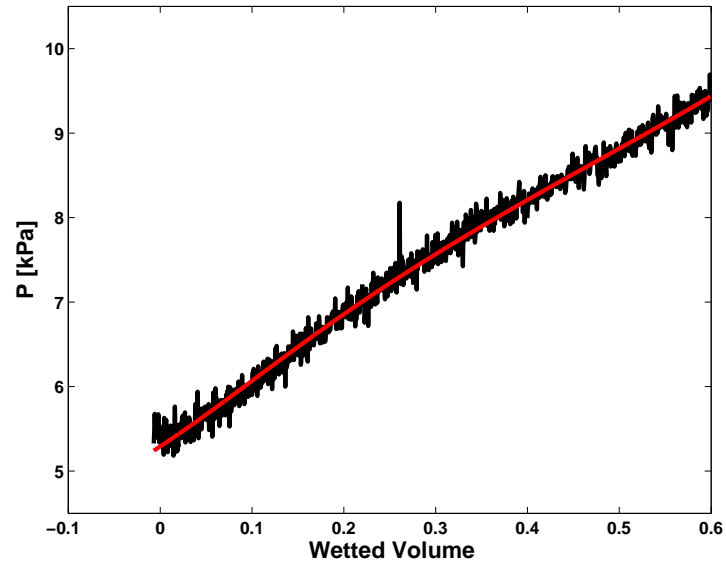

(f) $2^{\text {nd }}$ test at $96.53 \mathrm{kPa}$.

Figure 5.7. Percolation pressure vs Wetted volume plot of full CCM non-run catalyst layer sample. The tests were conducted at three different compressions on the sample $41.37 \mathrm{kPa}, 68.95 \mathrm{kPa}, 96.53 \mathrm{kPa}$ while holding the flow rate constant at $37.08 \mathrm{E}-4 \mathrm{mLs}^{-1}$. 


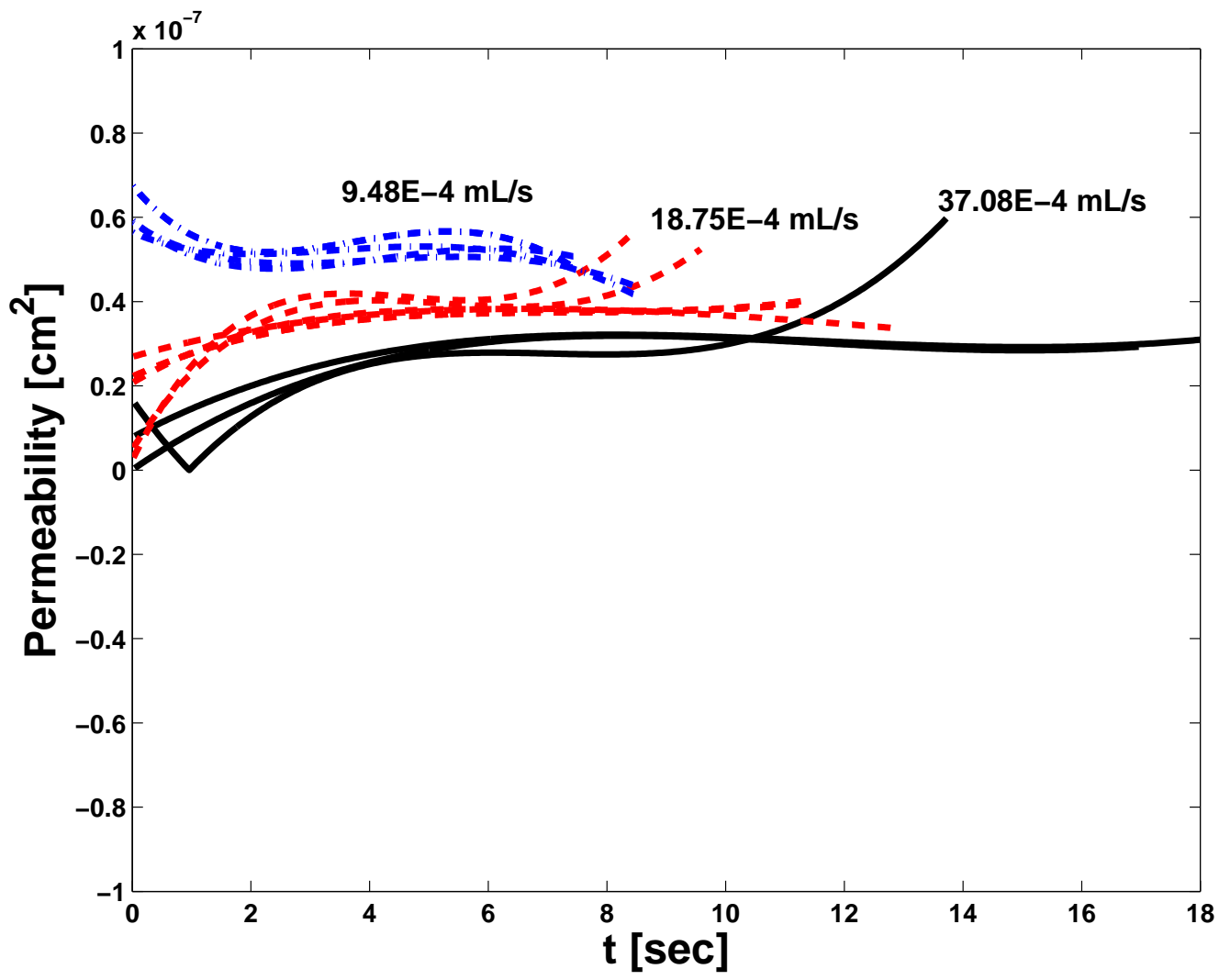

Figure 5.8. Permeability plot of non-run catalyst layer. 


\section{Conclusions}

Using the techniques for characterizing porous materials, PTLs and catalyst Layers from PEM Fuel Cells, two working apparatus have been built for investigating PEM fuel cell PTL and catalyst layer percolation. The visualization on the apparatus works well for seeing the saturation occurring during testing. The images taken from testing will be later examined for the wetted area which will be looked at versus the pressure. From the plots that were shown in the above study, the data is shown to be repeatable over a number of tests, showing a confident study.

The PTL data characterization gave a unique set of Ce-t* plots for both anode and cathode PTLs. The main goal of detecting structural changes due to aging the PTL sample was achieved using this method, seeing an offset Ce- $\mathrm{t}^{*}$ when compared to the conditioned and non-run samples. This offset or change tells that there are changes happening due to the aging process occurring within the sample and can be characterized using this method. This technique tells that aged samples can be characterized according to a structural change occurring within the PTL. This will help with model validation and can help with detecting the end of life of PTLs.

The catalyst layer samples showed that as the flow rate is doubled the data results in a higher pressure, however when the flow rate is doubled again the pressure cannot be seen to have increased from the plot. There was also a large difference amongst the non-run samples to the aged again which can be seen in the Pressure-Wetted Volume plots, showing that aged samples do allow as much fluid to pass through and the pressure is much lower. An explanation for this is not yet found but is suspected the aging process is the reason. A new method for assessing structure changes in catalyst layers has been developed and validated. 
APPENDICES 



\section{A. Nomenclature}

$\begin{array}{ll}\text { PEM } & \text { Proton Exchange Membrane } \\ \text { PTL } & \text { Porous Transport Layer } \\ \text { GDL } & \text { Gas Diffusion Layer } \\ \text { PTFE } & \text { Polytetrafluoroethylene } \\ \text { MPL } & \text { Microporous Layer } \\ \text { CCF } & \text { Catalyst Coated Film } \\ \text { CCM } & \text { Catalyst Coated Membrane } \\ \text { PDMS } & \text { Polydimethylsiloxane } \\ \text { PMMA } & \text { Polymethylmethacrylate } \\ \text { BOT } & \text { Beginning of Test } \\ \text { EOT } & \text { End of Test } \\ \text { Ca } & \text { Capillary Number } \\ \mathrm{M} & \text { Viscosity Ratio } \\ \mu_{\text {displacing }} & \text { Viscosity of displacing fluid } \\ \mu_{\text {displaced }} & \text { Viscosity of displaced fluid } \\ U_{\text {displacing }} & \text { Velocity of displacing fluid } \\ \sigma & \text { Interfacial tension of two fluids } \\ \text { Ce } & \text { Energy Ratio } \\ t^{*} & \text { Non-dimensional Time } \\ P & \text { Percolation Pressure } \\ Q & \text { Injection flow rate } \\ A & \text { Wetted area } \\ l & \text { Large length scale } \\ h & \text { Small length scale } \\ \mu & \text { Viscosity of the displacing fluid } \\ t & \text { Time duration of the experiment } \\ K & \text { Permeability Coefficient } \\ v & \text { Average velocity of displacing fluid } \\ \Delta \mathrm{x} & \text { Radial growth of the fluid interface } \\ \Delta \mathrm{P} & \text { Percolation pressure } \\ & \\ & \end{array}$




\section{B. PtL Percolation Pressure Plots}




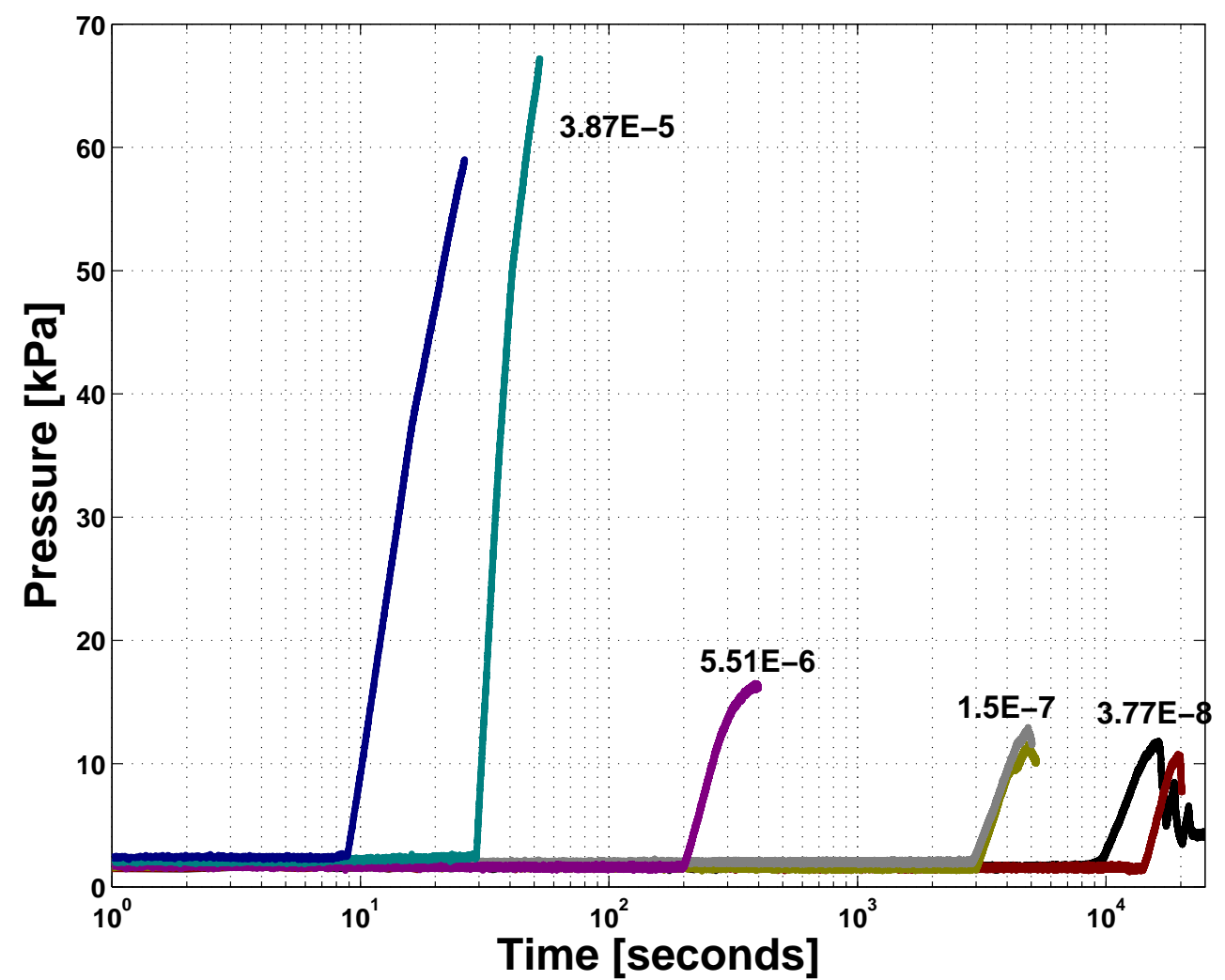

Figure B.1. Percolation Pressures for the Cathode Non-Run Substrate. The capillary numbers for the corresponding test are shown. 


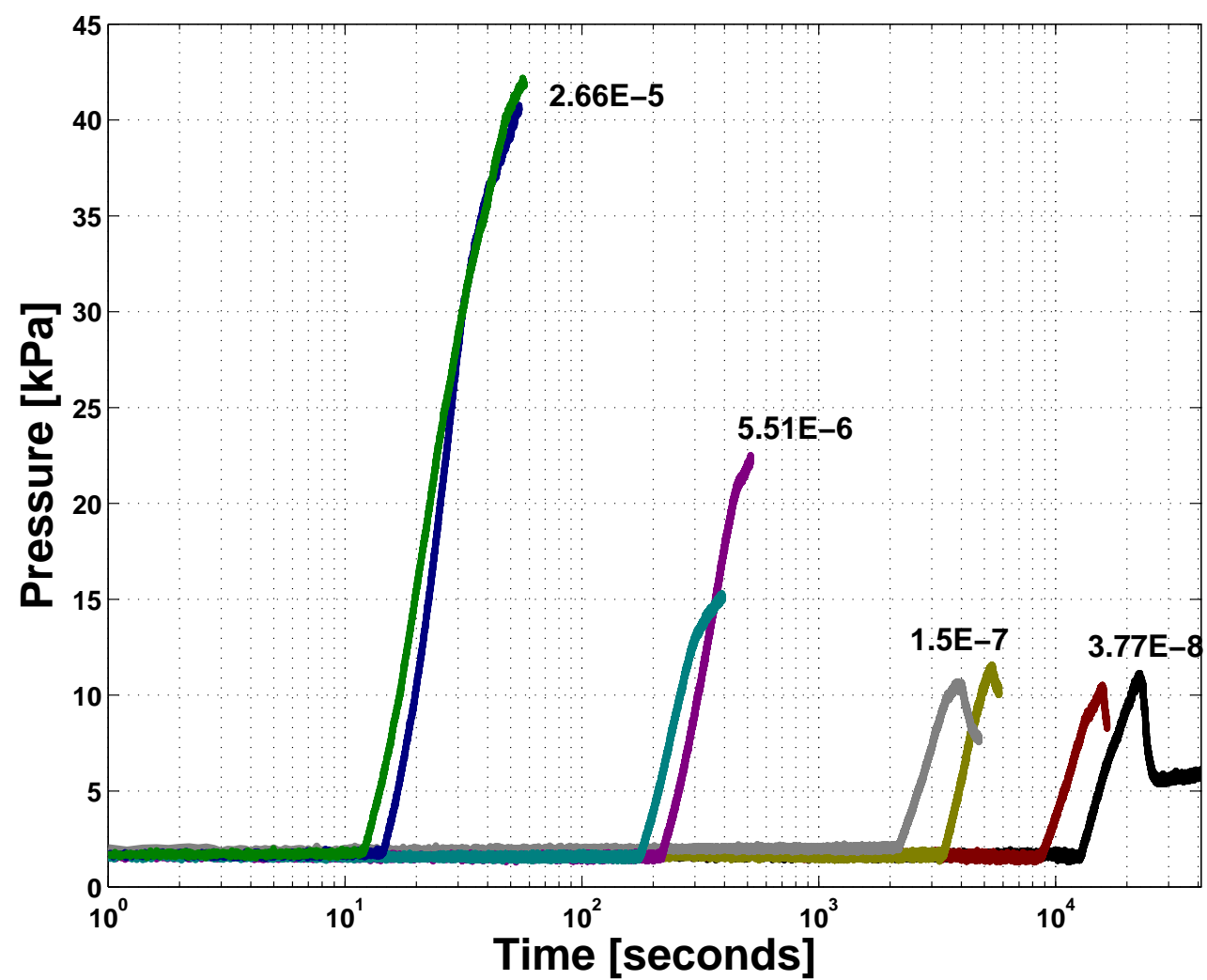

Figure B.2. Percolation Pressures for the Cathode Non-Run PTL sample 1. The capillary numbers for the corresponding test are shown. 


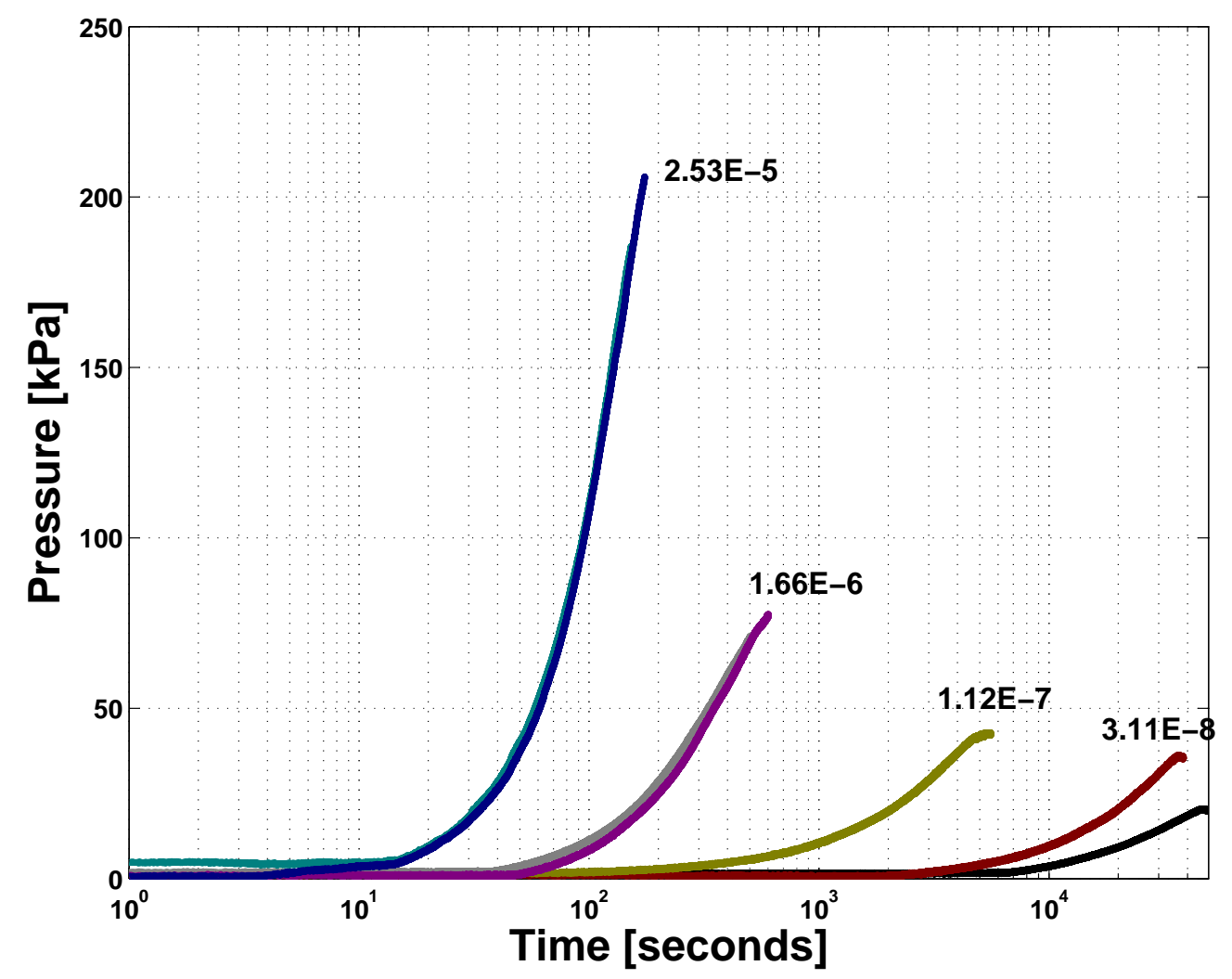

Figure B.3. Percolation Pressures for the Anode Non-Run PTL sample. The capillary numbers for the corresponding test are shown. 


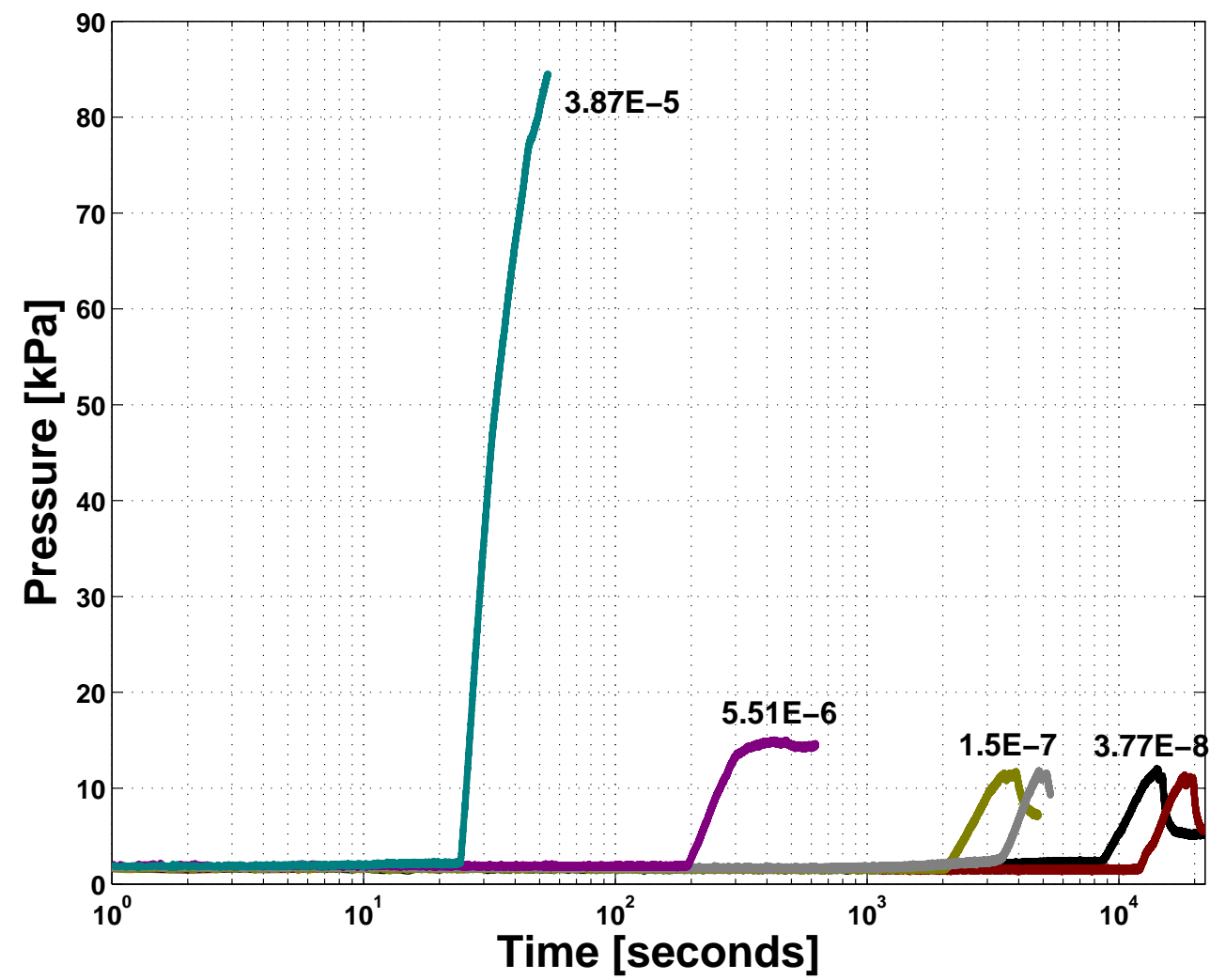

Figure B.4. Percolation Pressures for the Cathode Non-Run PTL sample 2. The capillary numbers for the corresponding test are shown. 


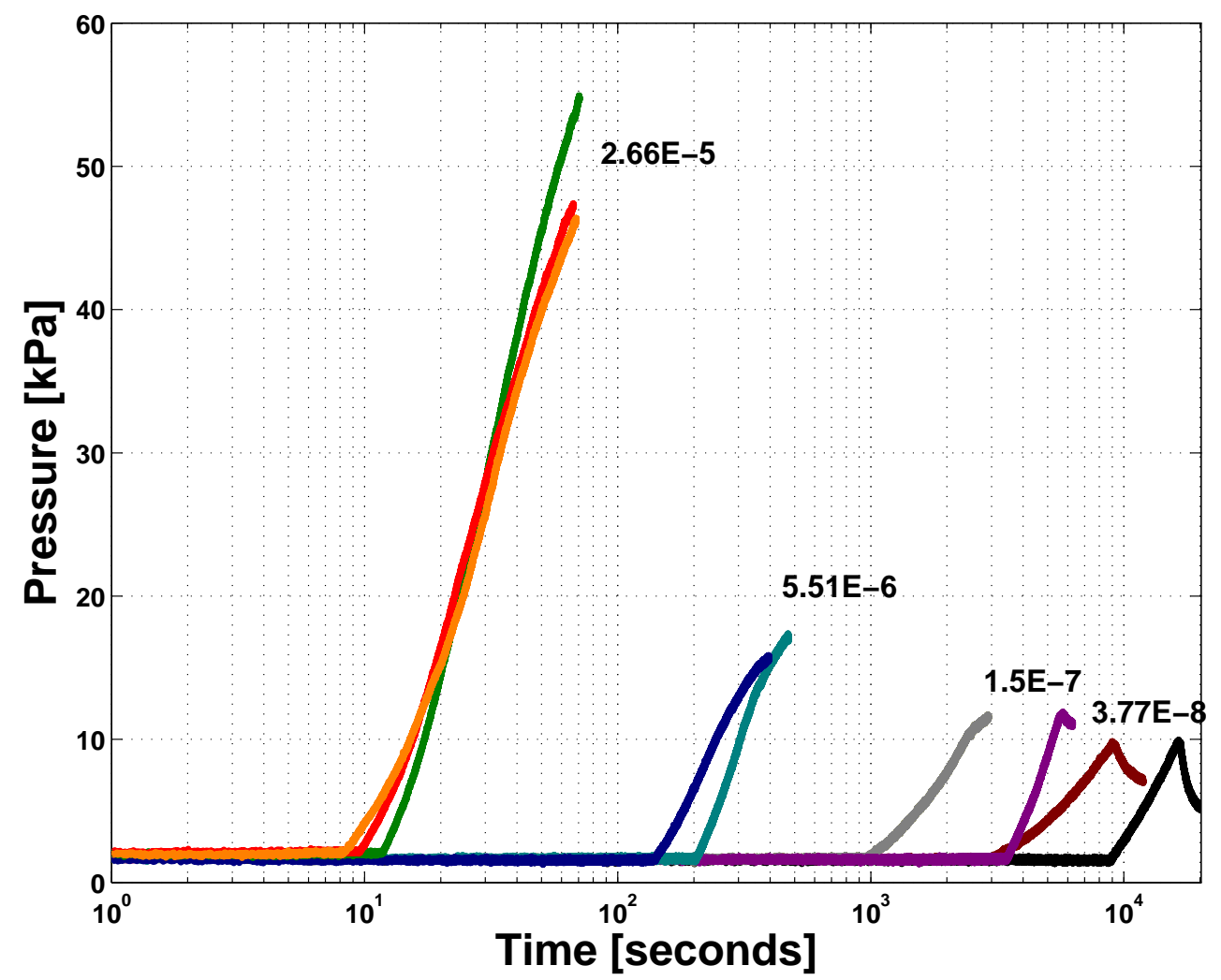

Figure B.5. Percolation Pressures for the Cathode Condtioned PTL. The capillary numbers for the corresponding test are shown. 


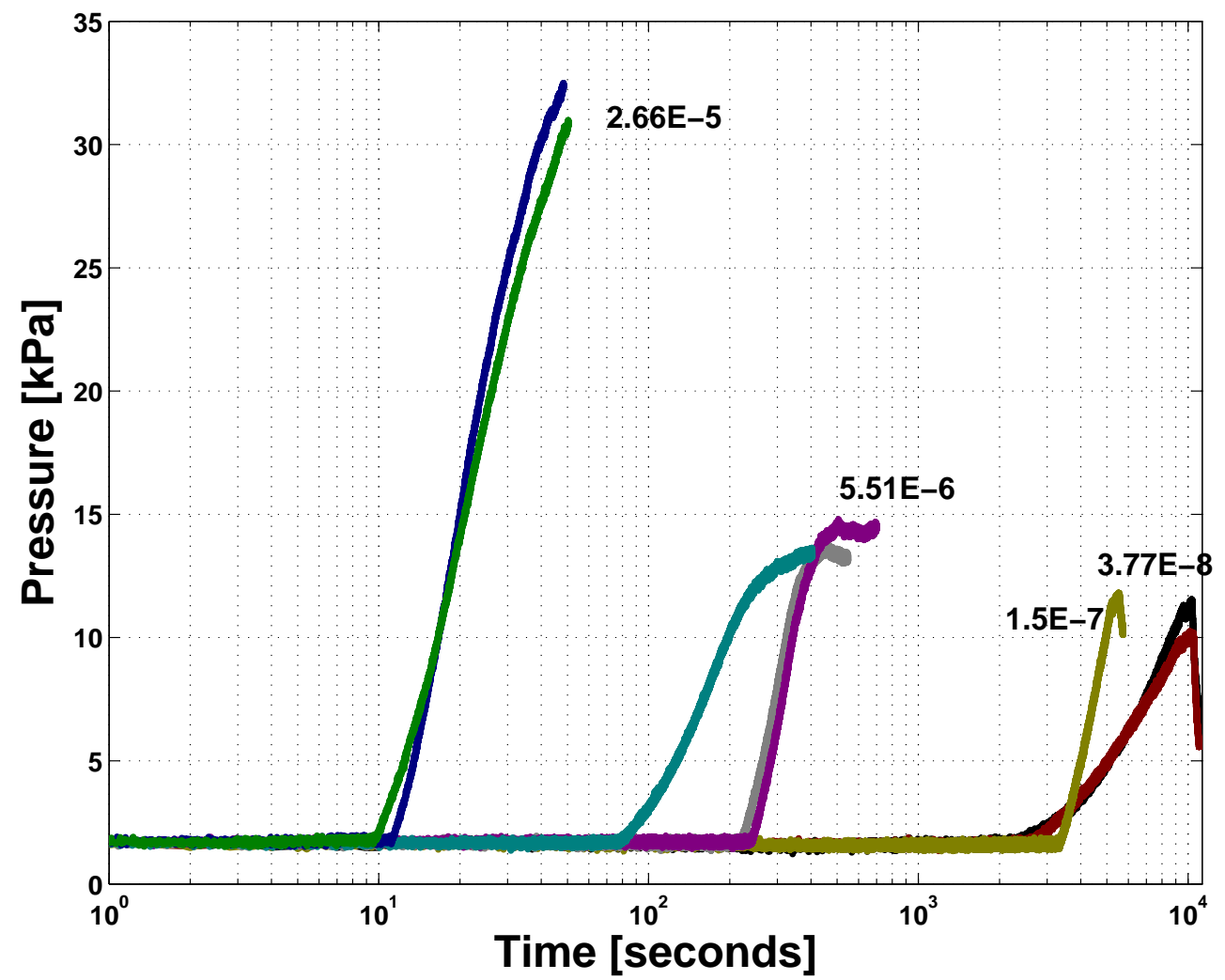

Figure B.6. Percolation Pressures for the Anode Conditioned PTL. The capillary numbers for the corresponding test are shown. 


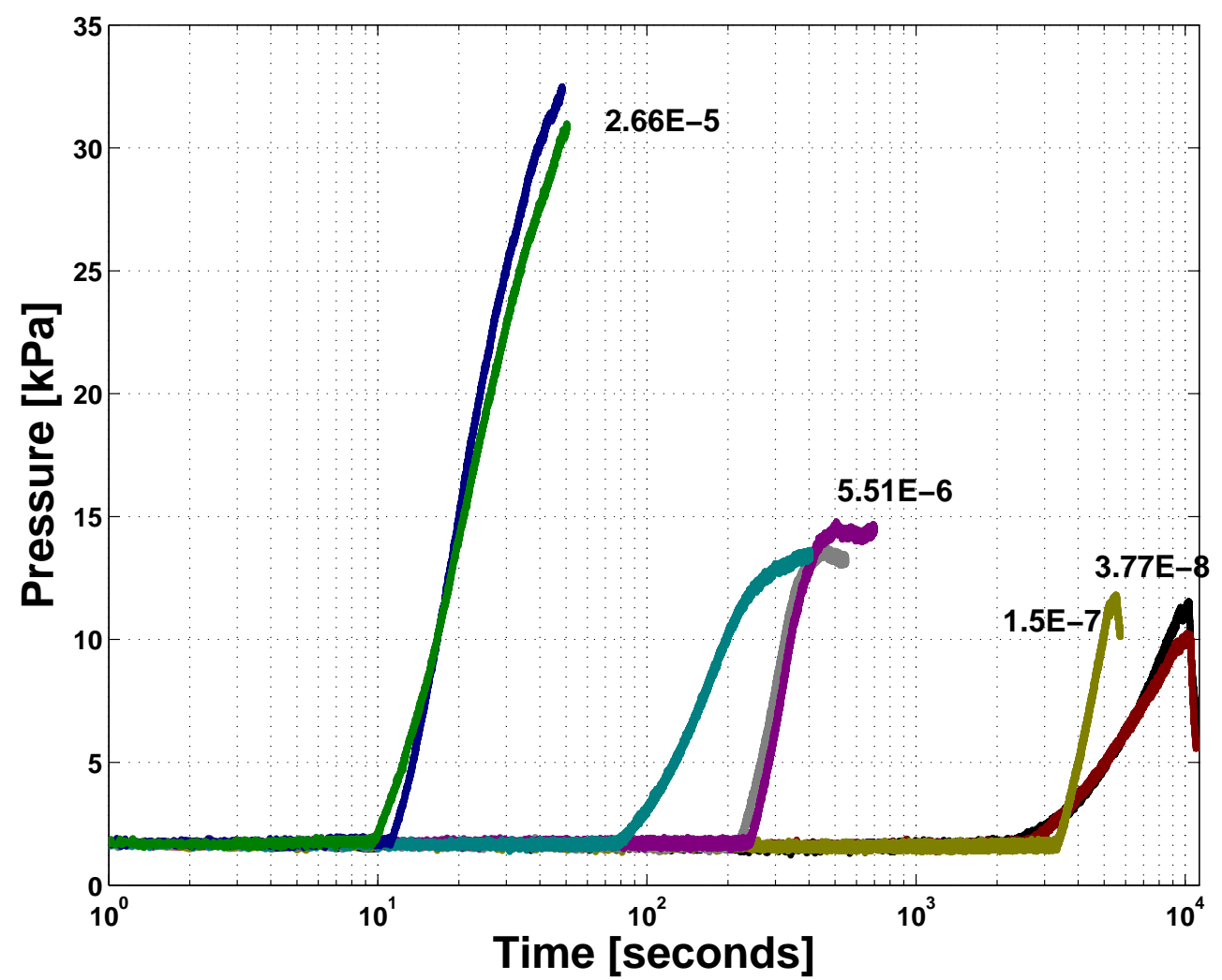

Figure B.7. Percolation Pressures for the Cathode Aged PTL. The capillary numbers for the corresponding test are shown. 


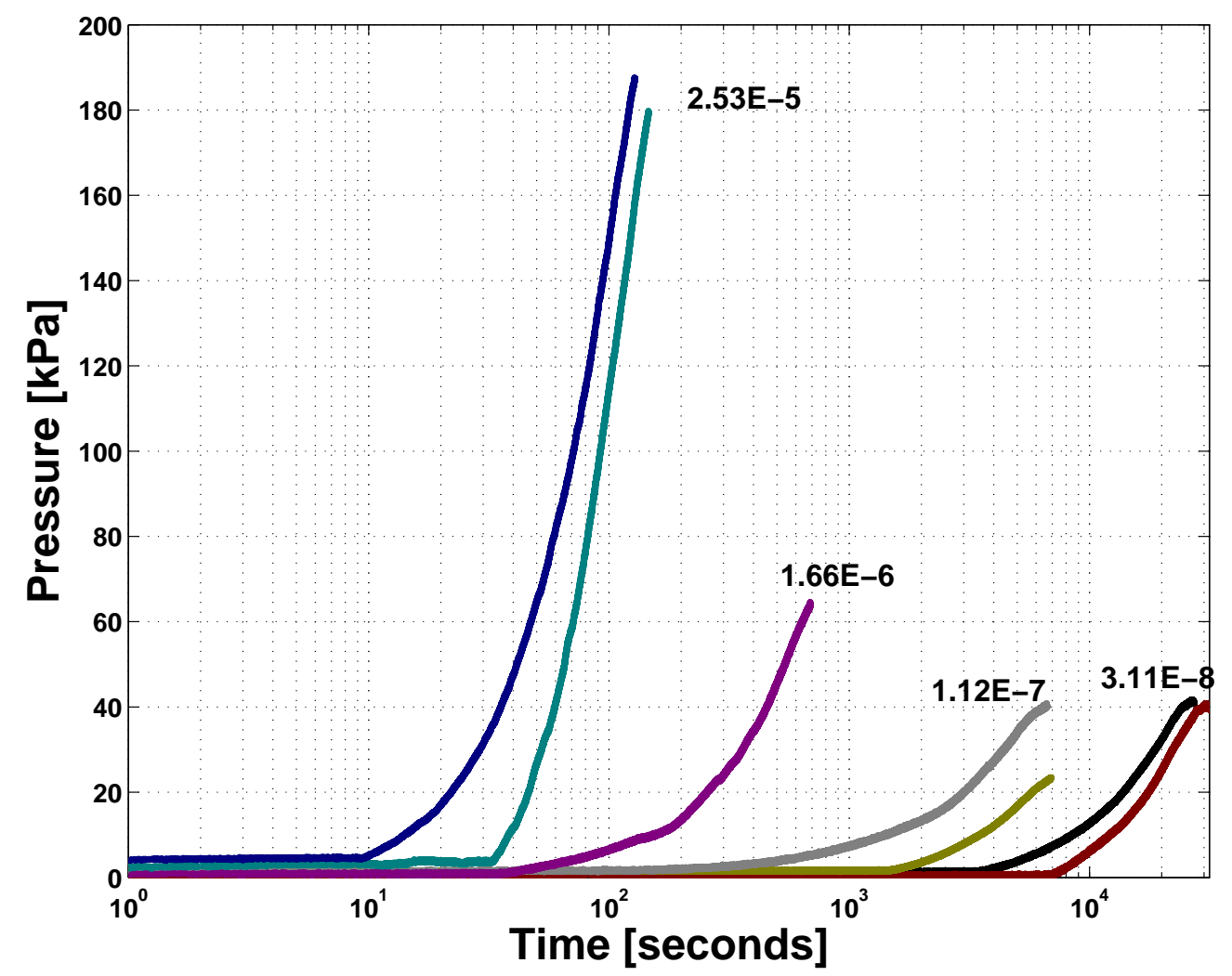

Figure B.8. Percolation Pressures for the Anode Aged PTL. The capillary numbers for the corresponding test are shown. 


\section{PTL Area Plots}




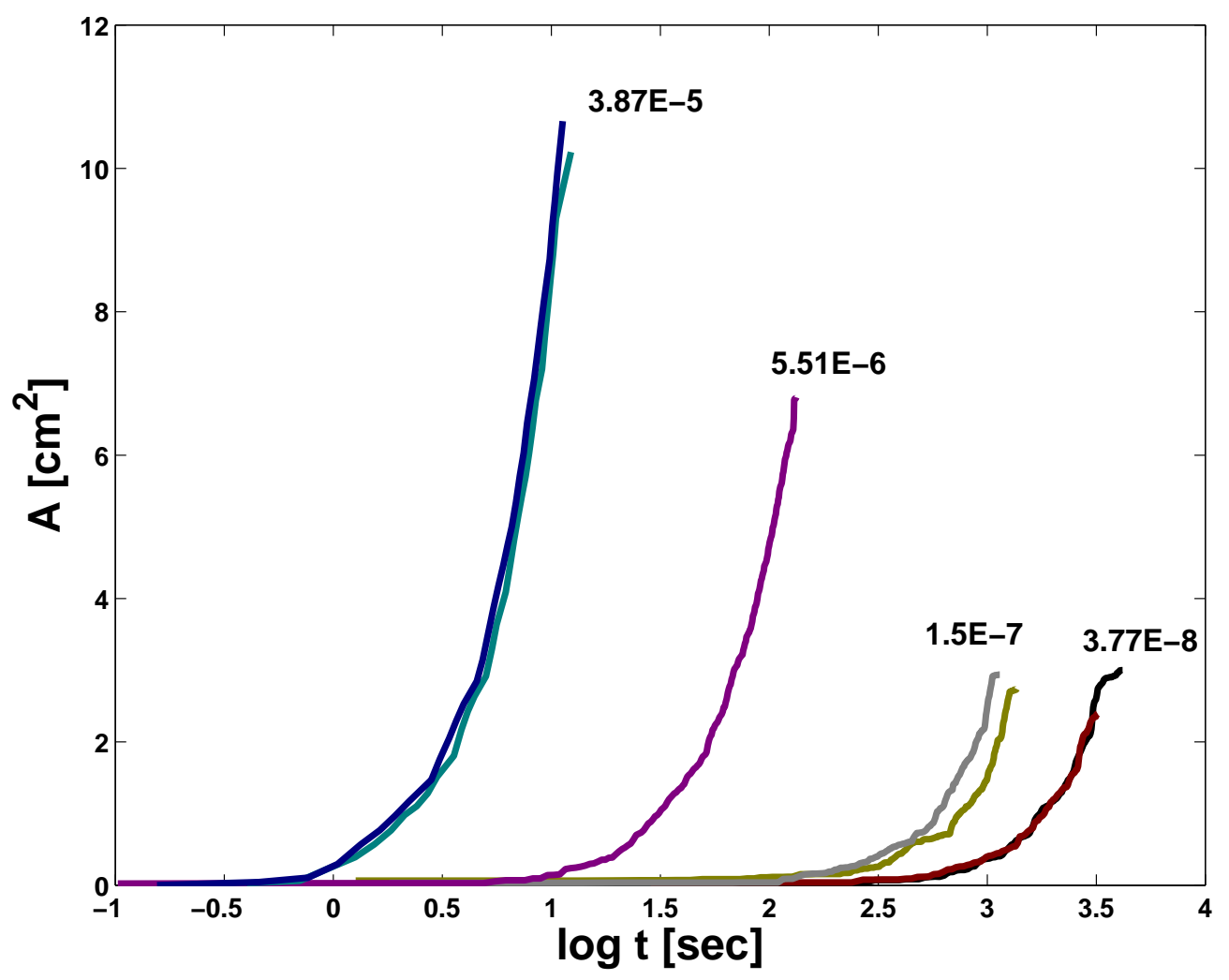

Figure C.1. Area growth rate forCathode Substrate Nonrun. The capillary numbers for each line are shown. 


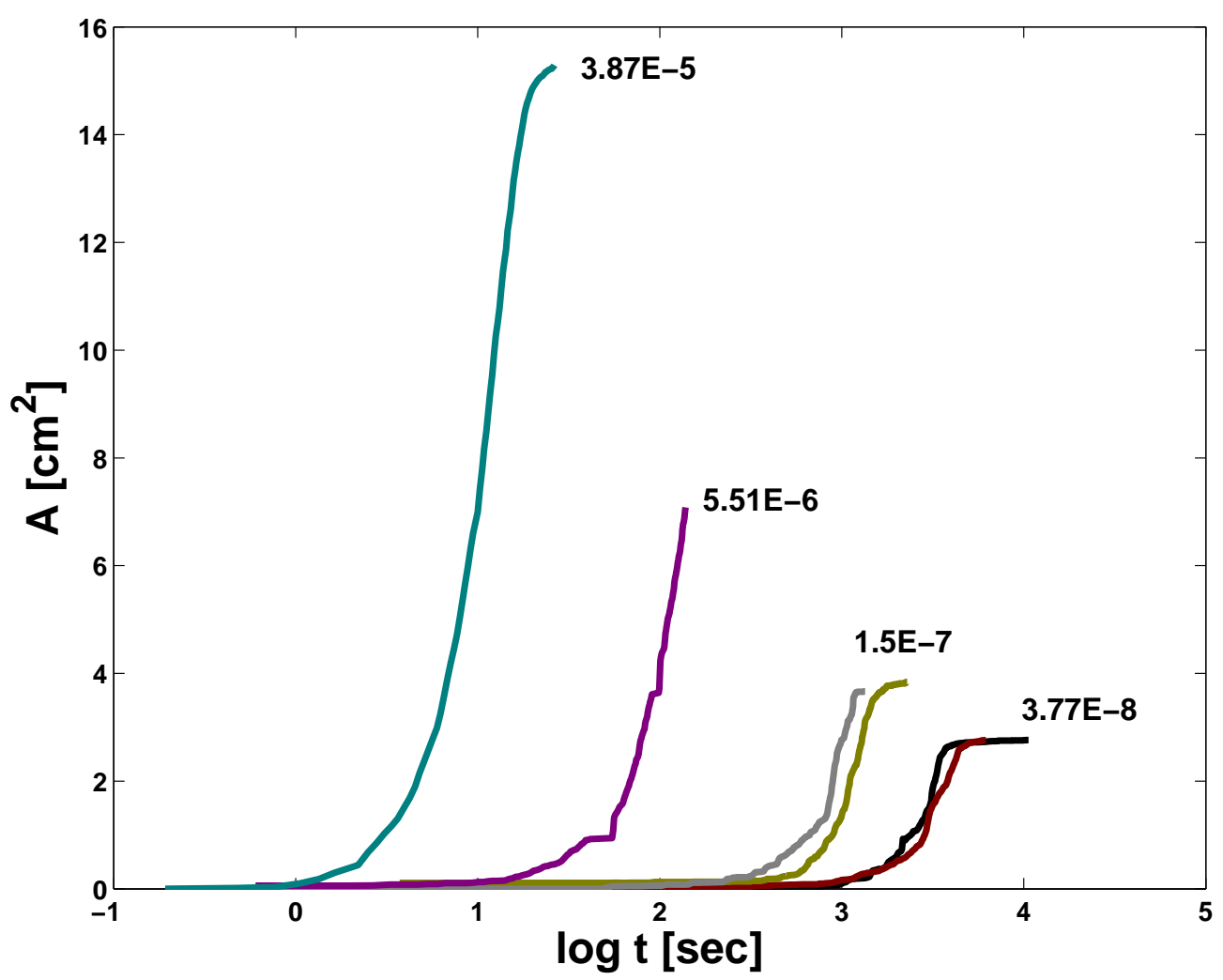

Figure C.2. Area growth rate for Cathode PTL Nonrun Sample 1. The capillary numbers for each line are shown. 


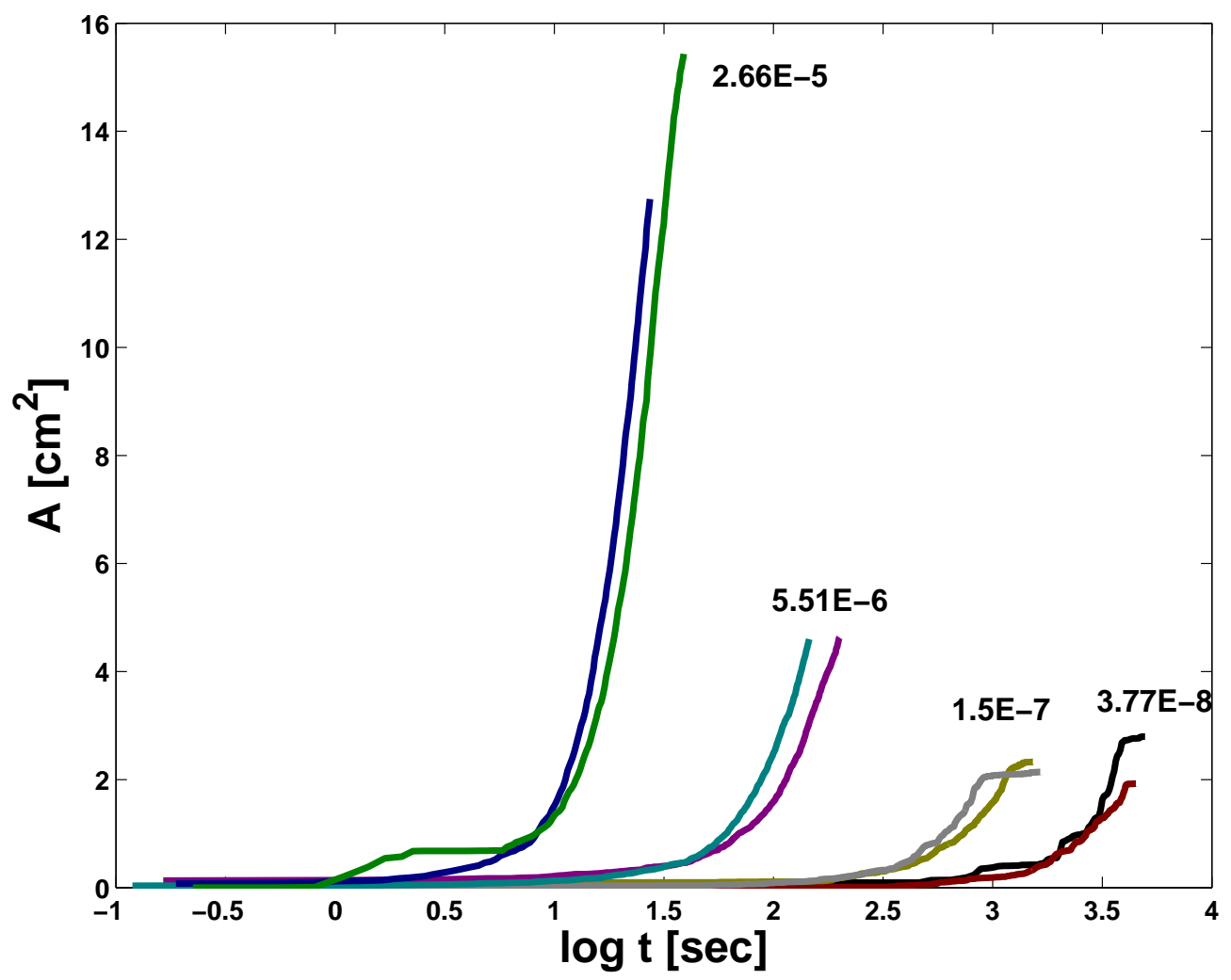

Figure C.3. Area growth rate for Cathode PTL Nonrun Sample 2. The capillary numbers for each line are shown. 


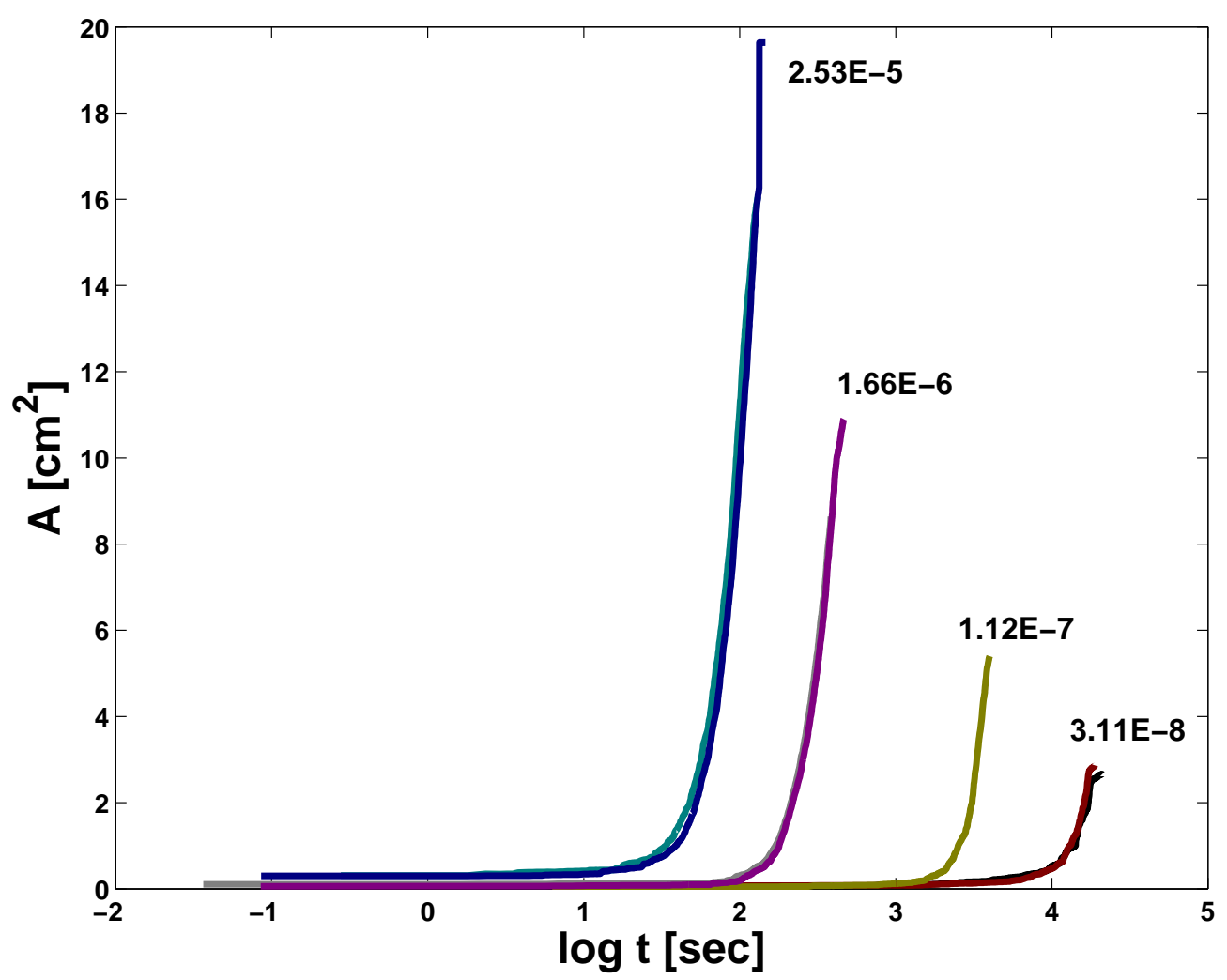

Figure C.4. Area growth rate for Anode PTL Nonrun. The capillary numbers for each line are shown. 


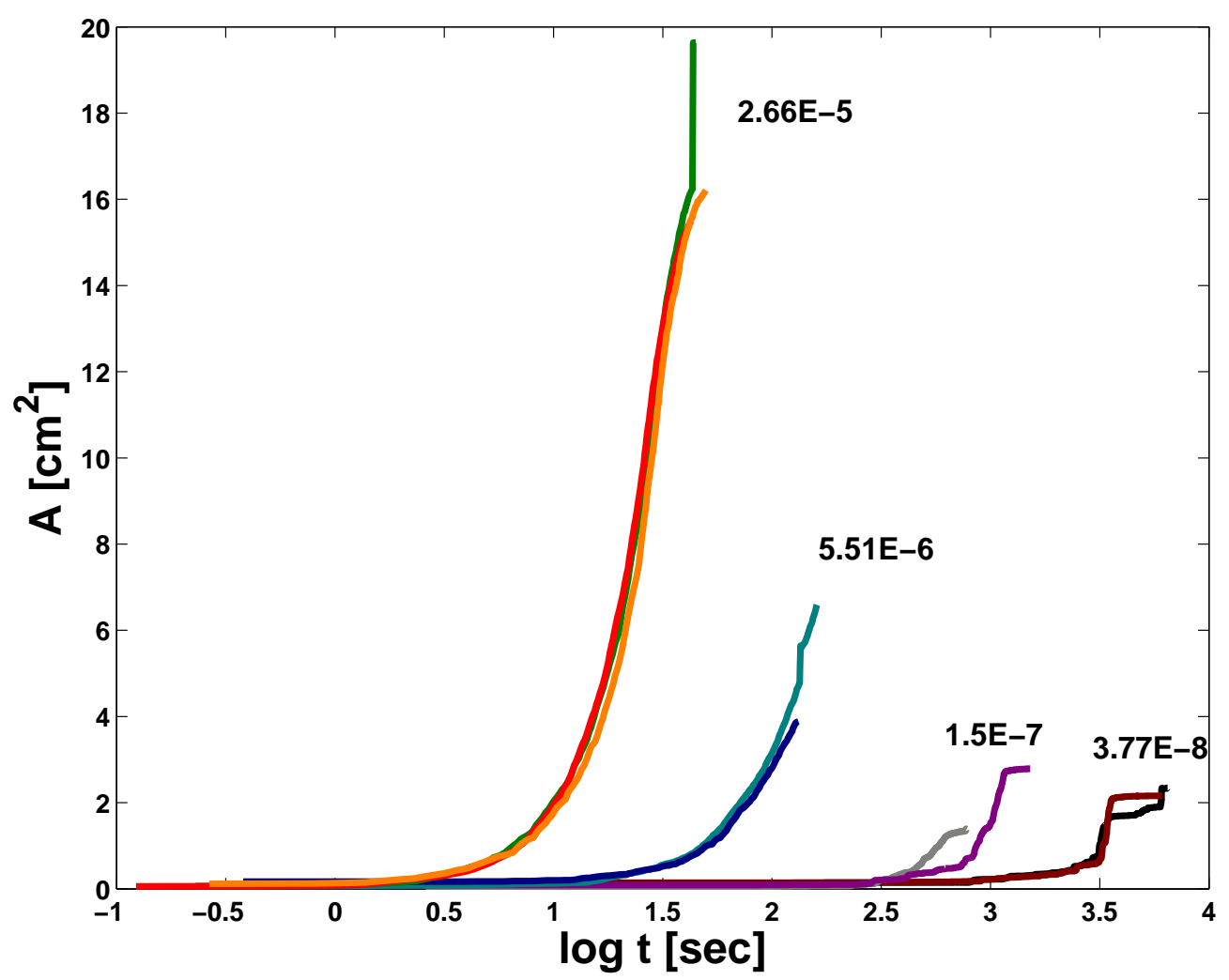

Figure C.5. Area growth rate for Cathode PTL Conditioned. The capillary numbers for each line are shown. 


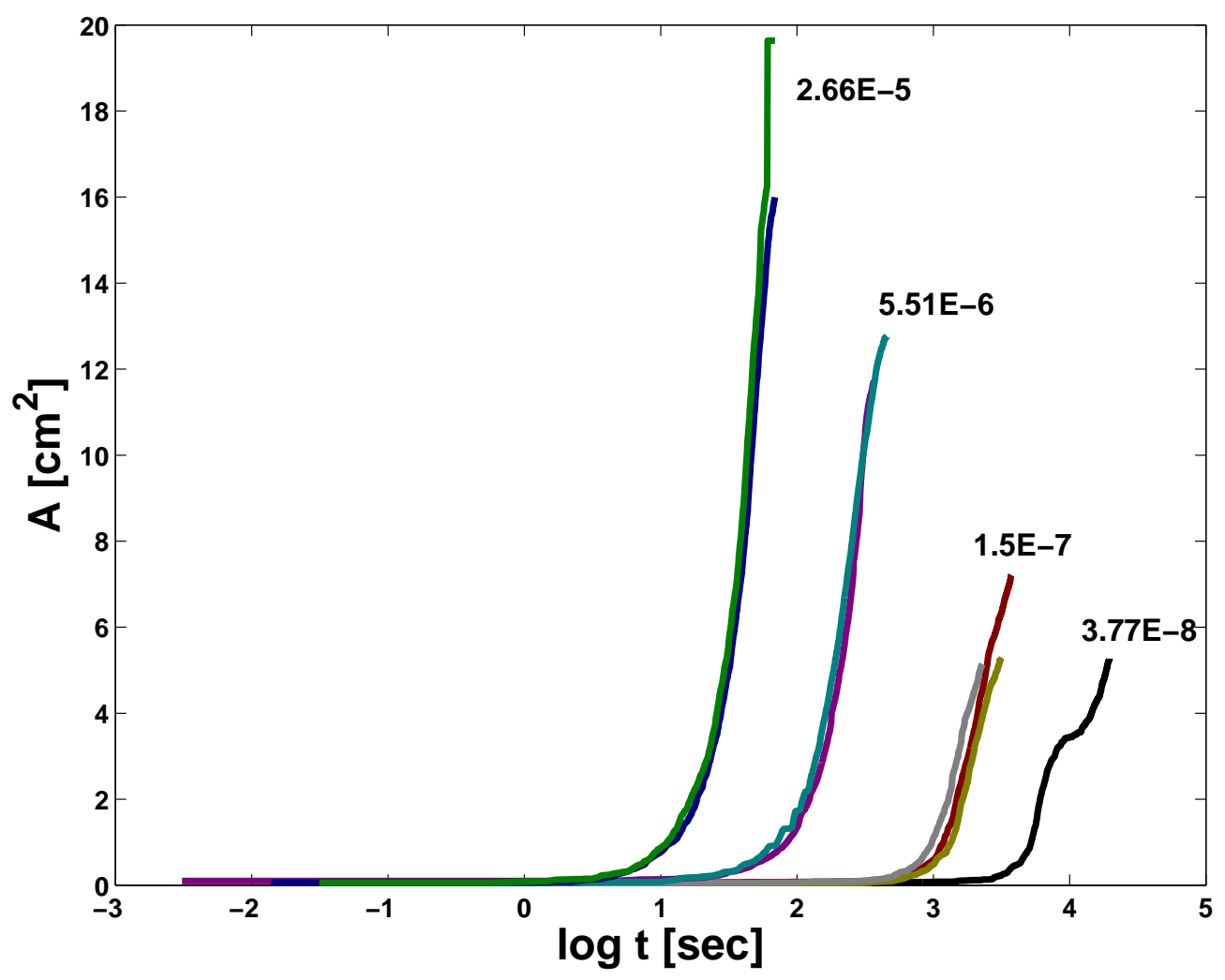

Figure C.6. Area growth rate for Anode PTL Conditioned. The capillary numbers for each line are shown. 


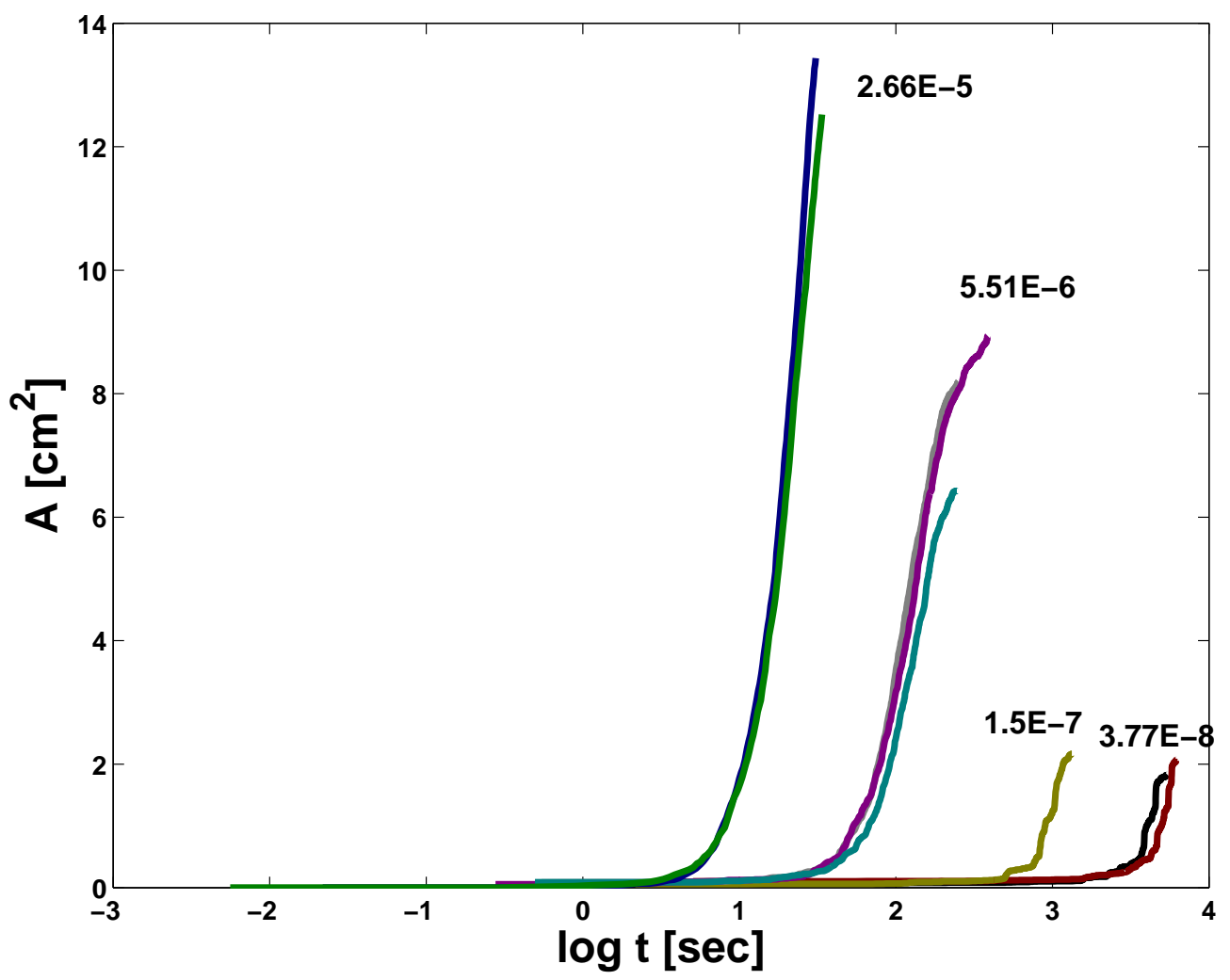

Figure C.7. Area growth rate for Cathode PTL Aged. The capillary numbers for each line are shown. 


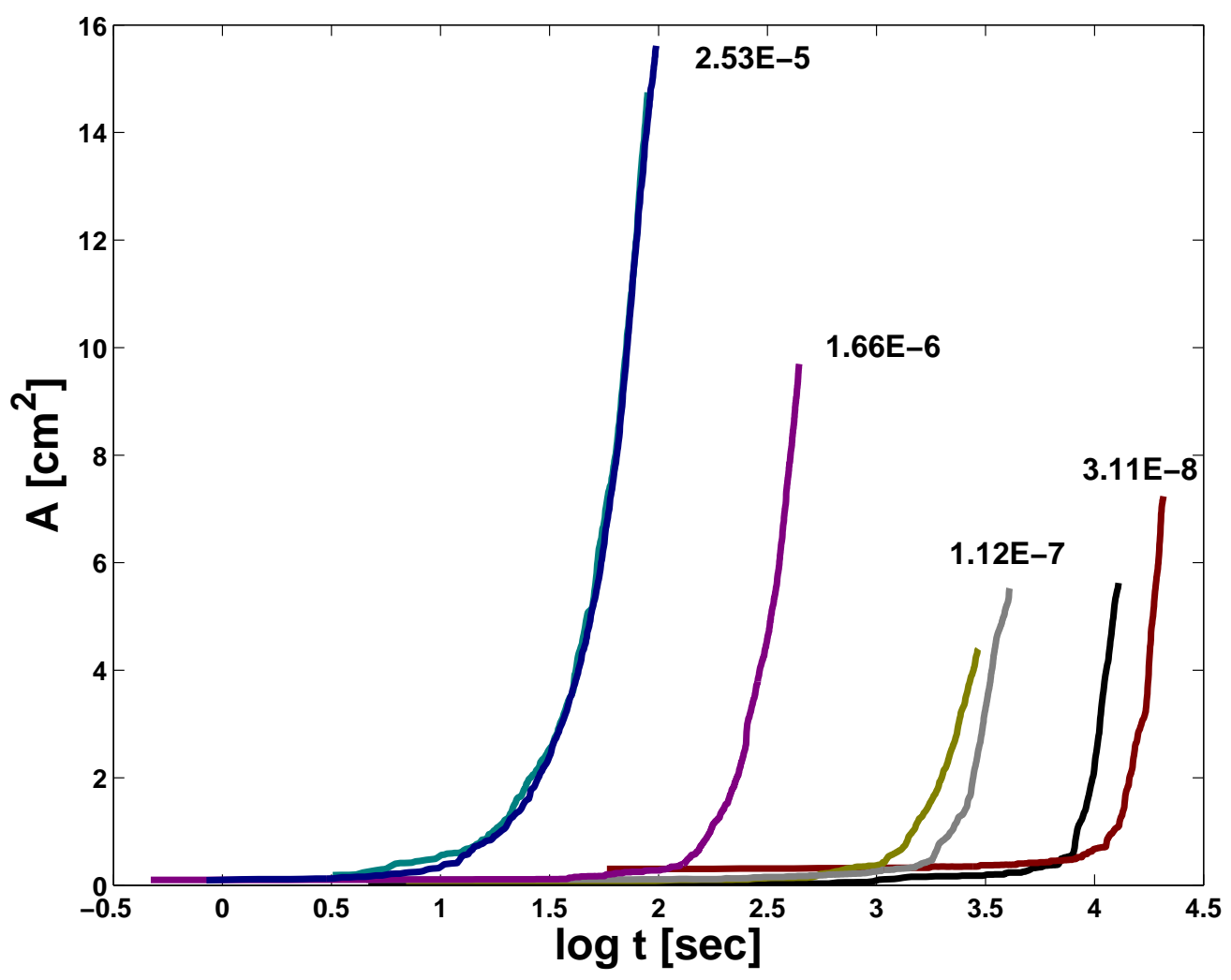

Figure C.8. Area growth rate for Anode PTL Aged. The capillary numbers for each line are shown. 


\section{PTL Ce Plots}




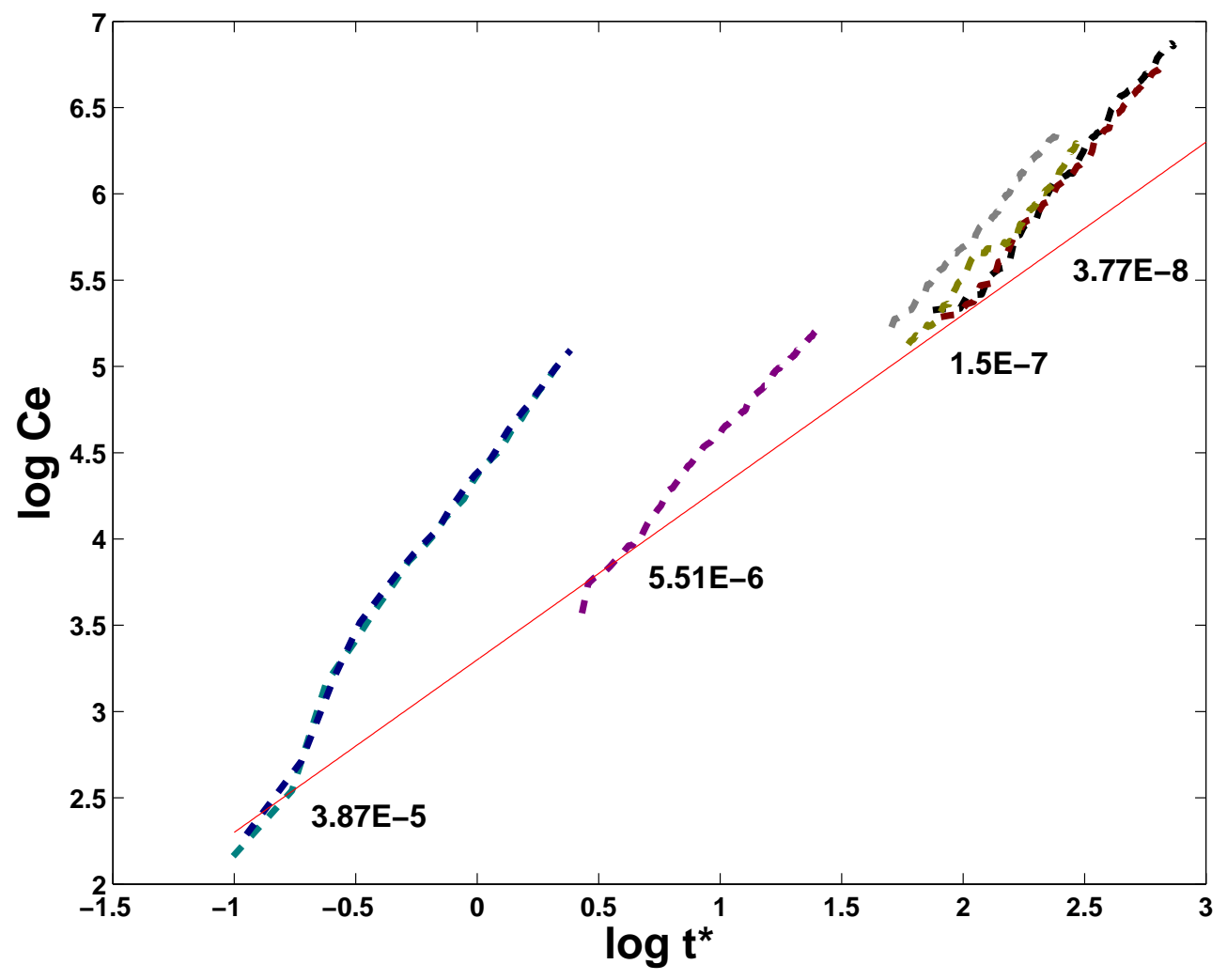

Figure D.1. Ce data for Cathode Substrate Nonrun. The capillary numbers for each line are shown. The solid line represents a slope of one. 


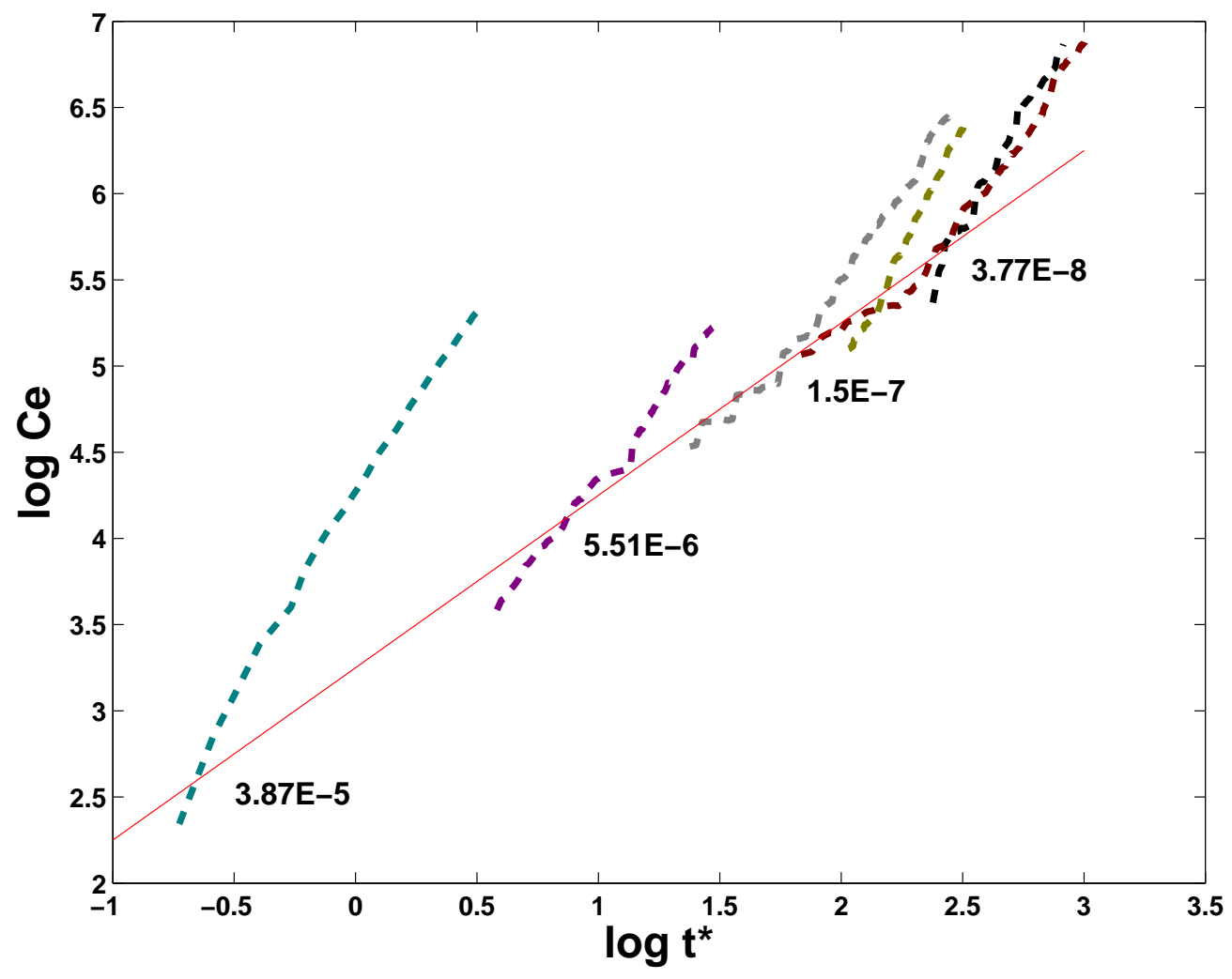

Figure D.2. Ce data for Cathode PTL Nonrun Sample 1. The capillary numbers for each line are shown. The solid line represents a slope of one. 


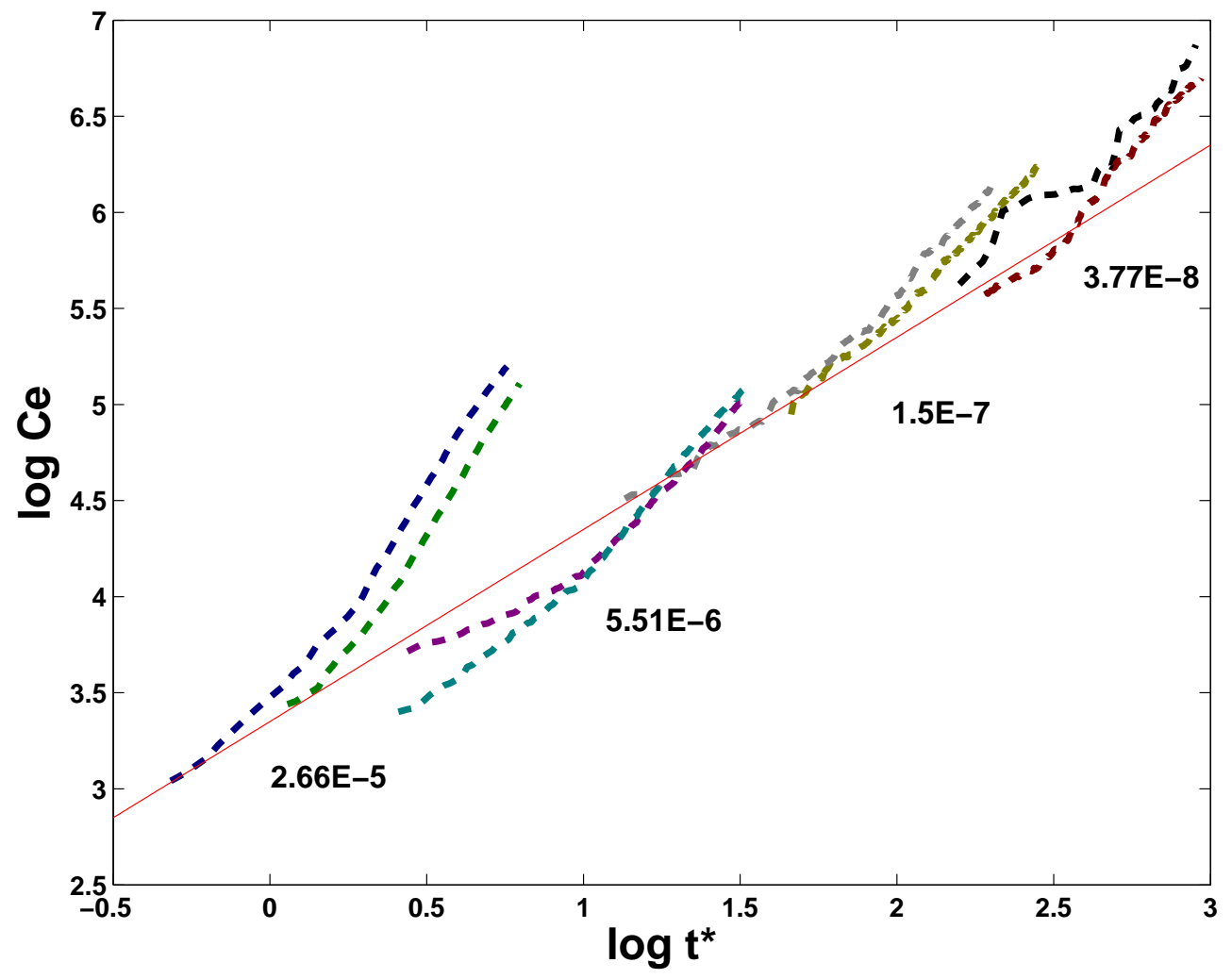

Figure D.3. Ce data for Cathode PTL Nonrun Sample 2. The capillary numbers for each line are shown. The solid line represents a slope of one. 


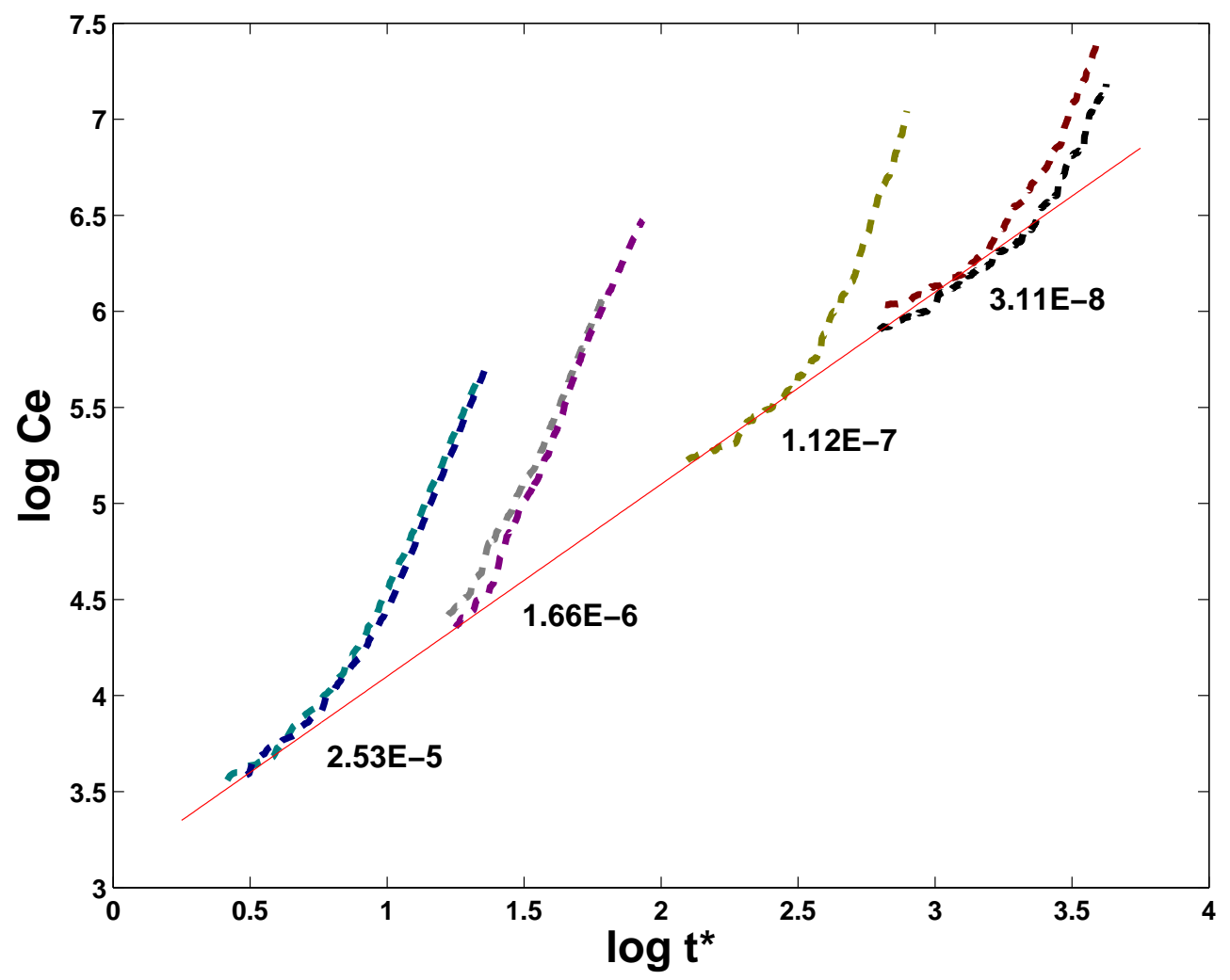

Figure D.4. Ce data for Anode PTL Nonrun. The capillary numbers for each line are shown. The solid line represents a slope of one. 


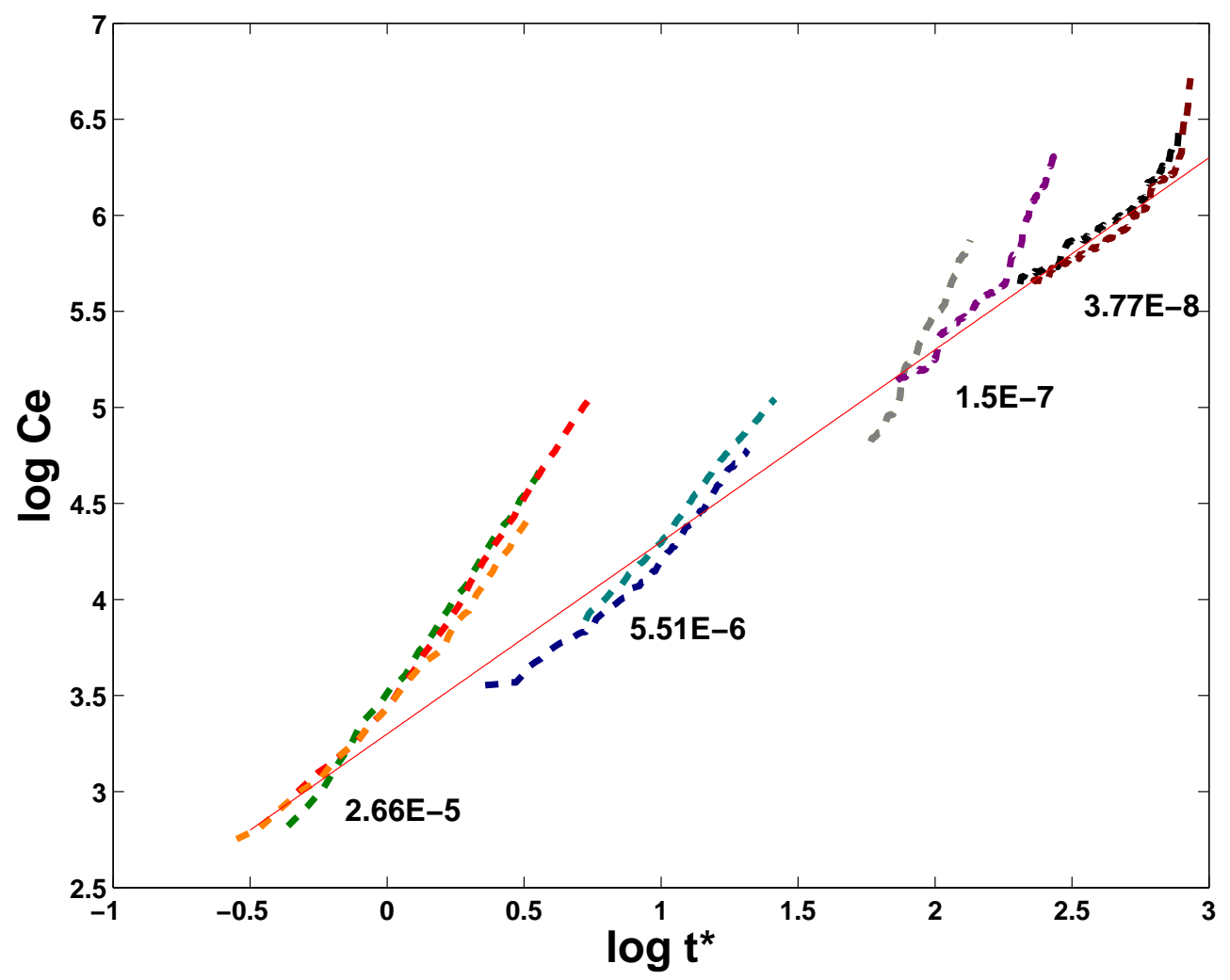

Figure D.5. Ce data for Cathode PTL Conditioned. The capillary numbers for each line are shown. The solid line represents a slope of one. 


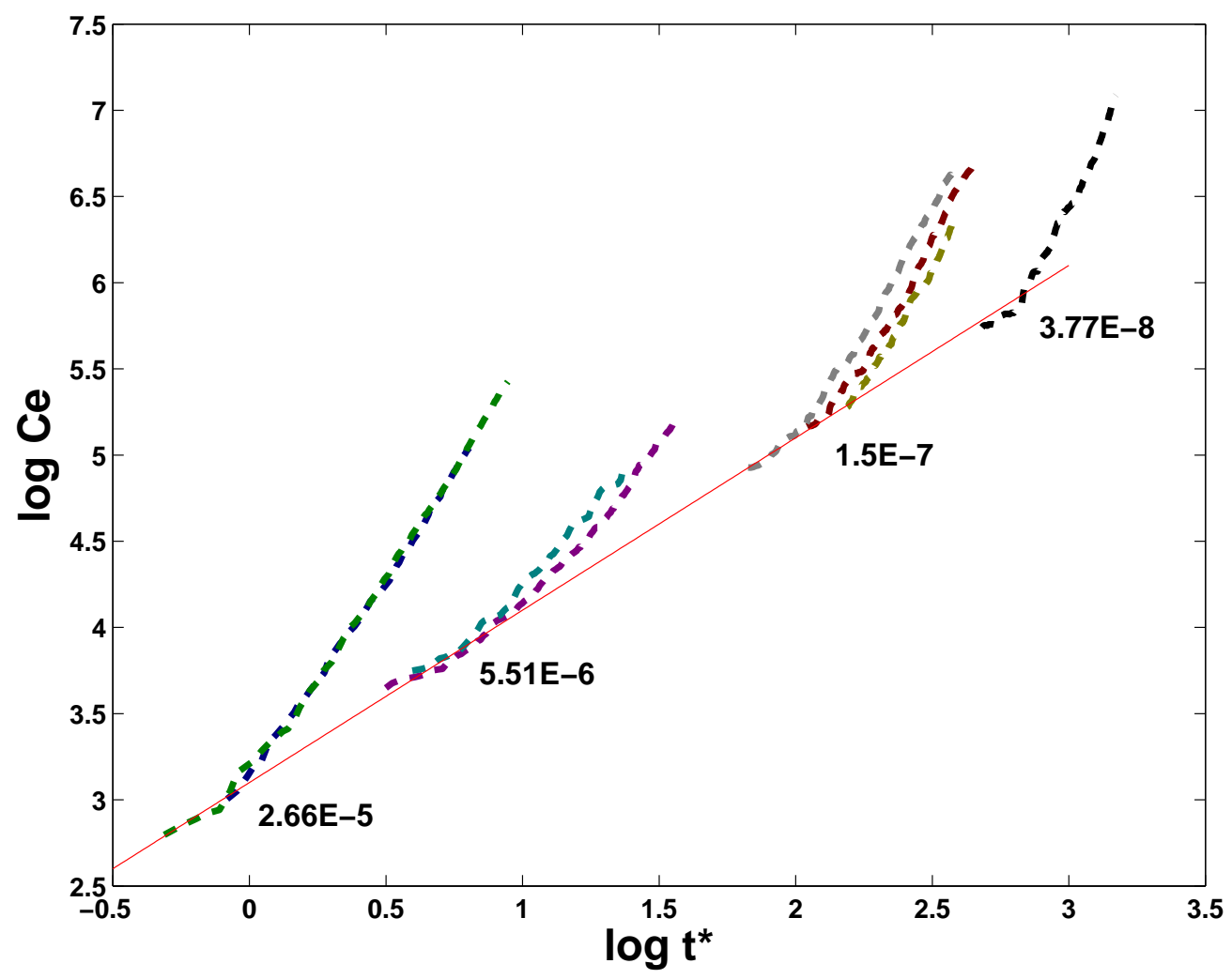

Figure D.6. Ce data for Anode PTL Conditioned. The capillary numbers for each line are shown. The solid line represents a slope of one. 


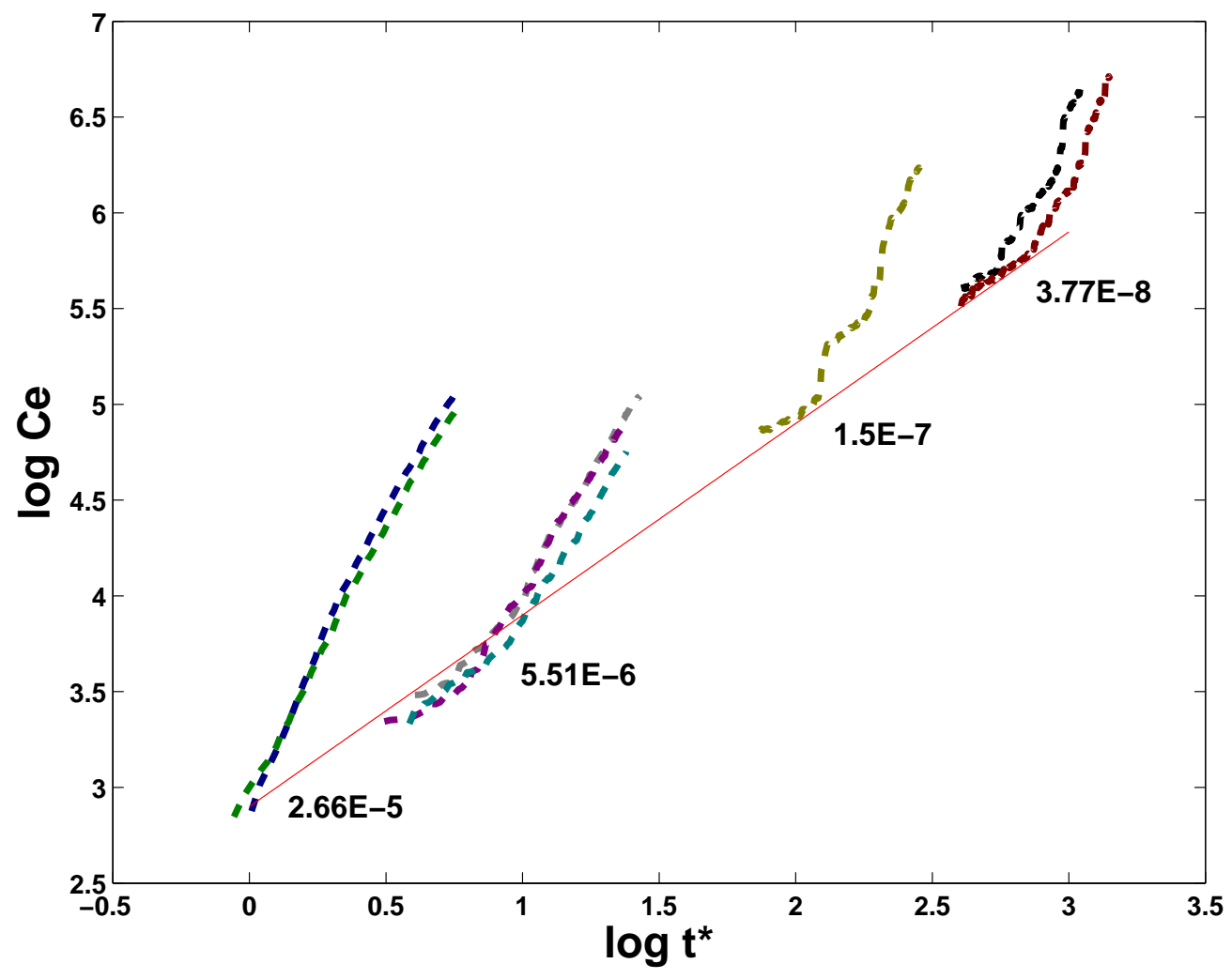

Figure D.7. Ce data for Cathode PTL Aged. The capillary numbers for each line are shown. The solid line represents a slope of one. 


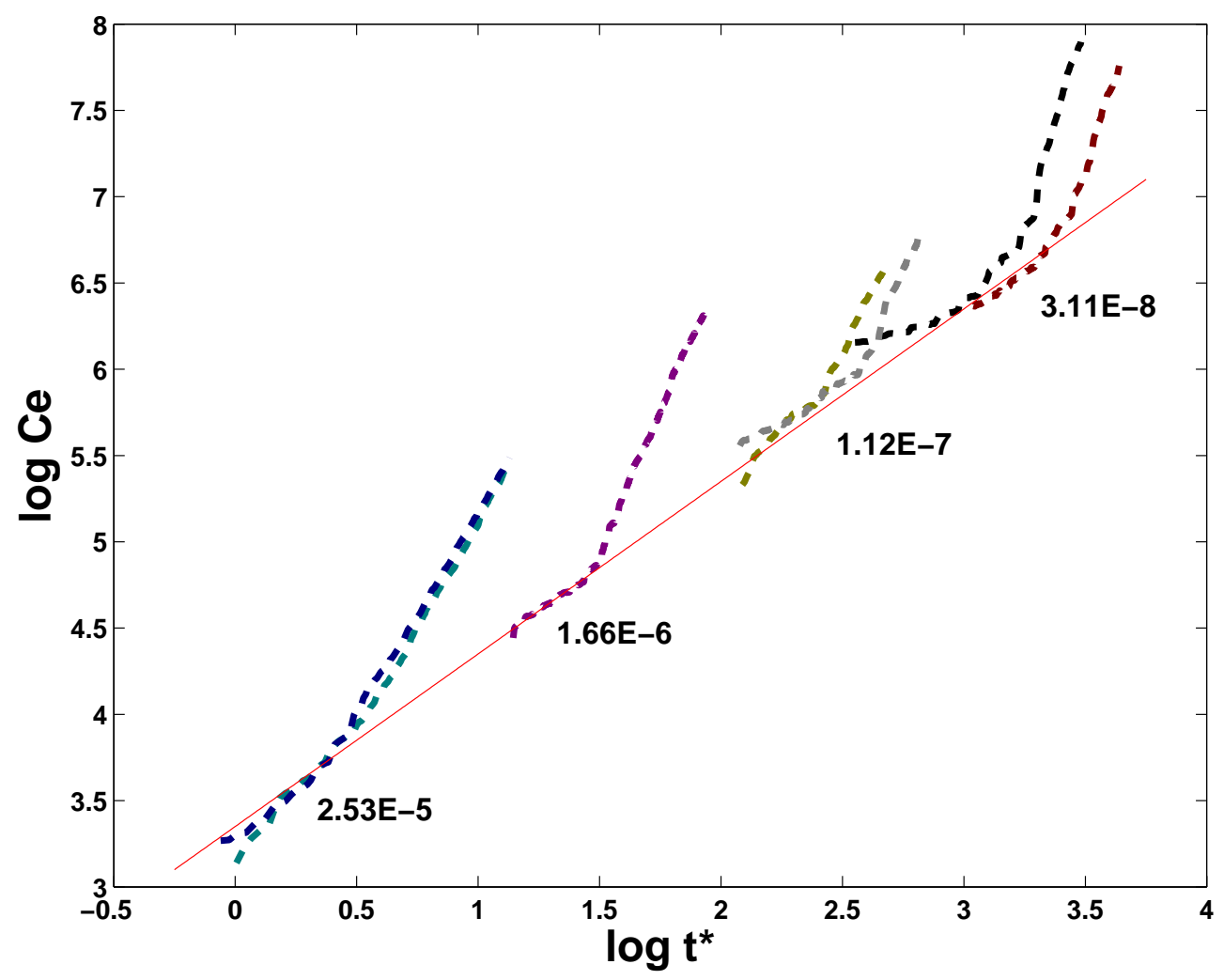

Figure D.8. Ce data for Anode PTL Aged. The capillary numbers for each line are shown. The solid line represents a slope of one. 


\section{E. Process 1 and Process 2 Catalyst LAYER PRessure Plots}




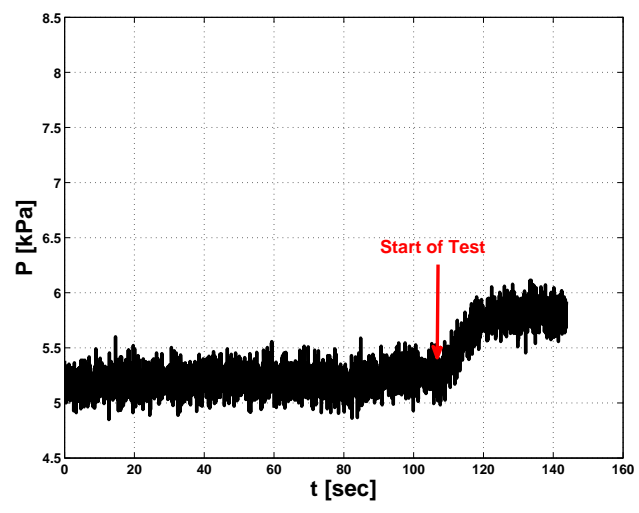

(a) $41.37 \mathrm{kPa}$ Compression

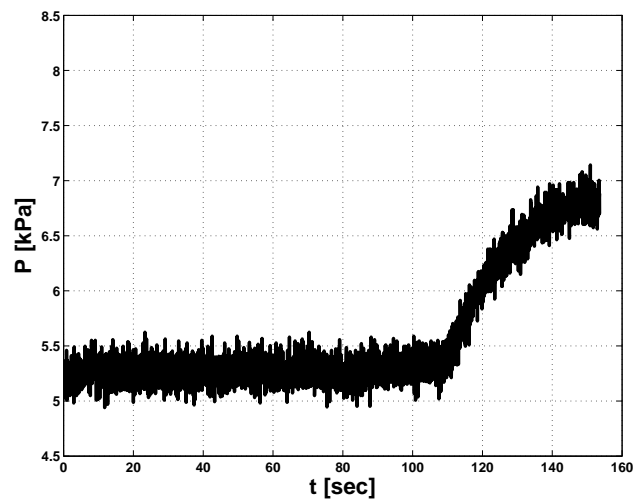

(c) $82.74 \mathrm{kPa}$ Compression

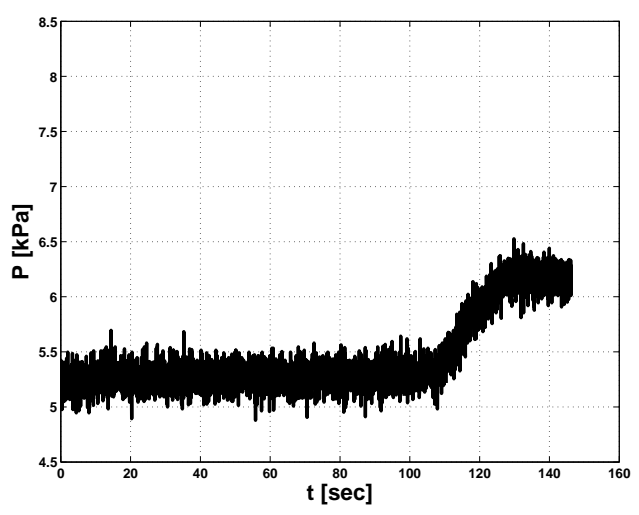

(b) $55.16 \mathrm{kPa}$ Compression

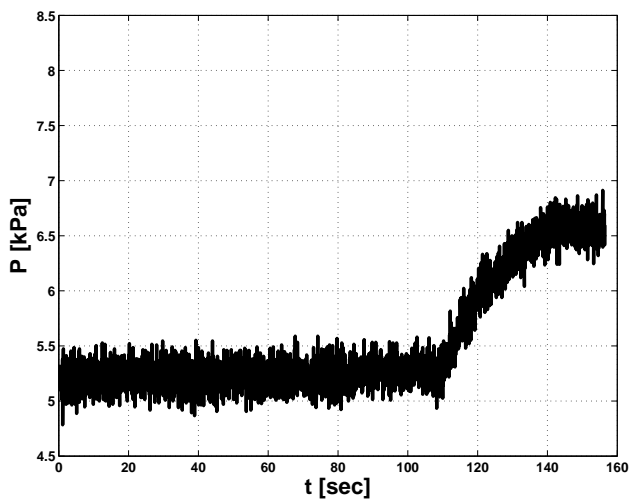

(d) $96.53 \mathrm{kPa}$ Compression

Figure E.1. Percolation pressure for Process 1. The tests were conducted at three different compressions on the sample $41.37 \mathrm{kPa}, 55.16 \mathrm{kPa}, 82.74 \mathrm{kPa}$, $96.53 \mathrm{kPa}$ while holding the flow rate constant at $9.48 \mathrm{E}-4 \mathrm{mLs}^{-1}$. 


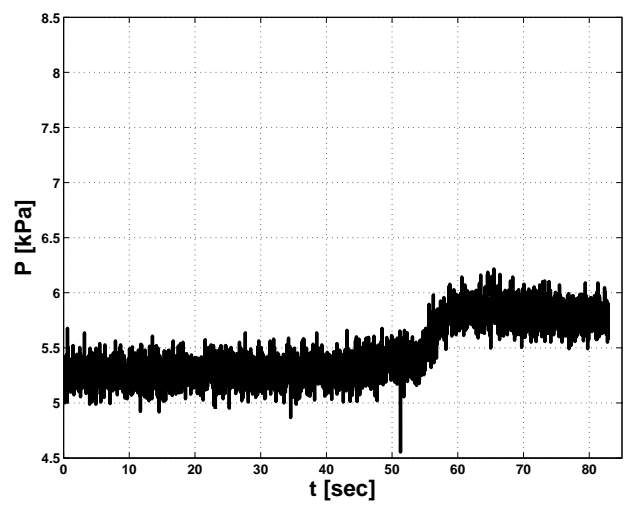

(a) $41.37 \mathrm{kPa}$ Compression

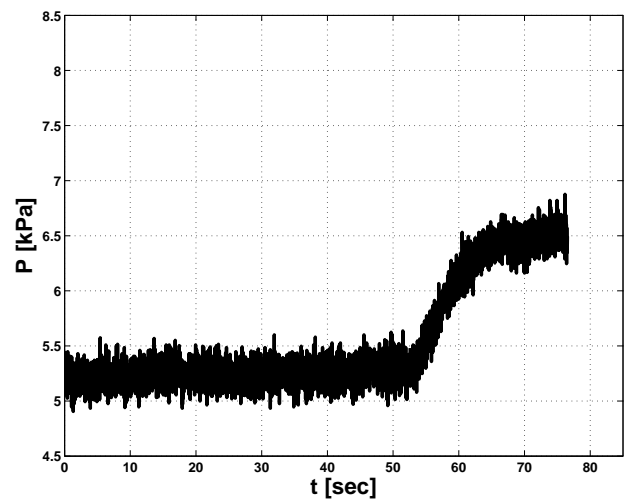

(c) $82.74 \mathrm{kPa}$ Compression

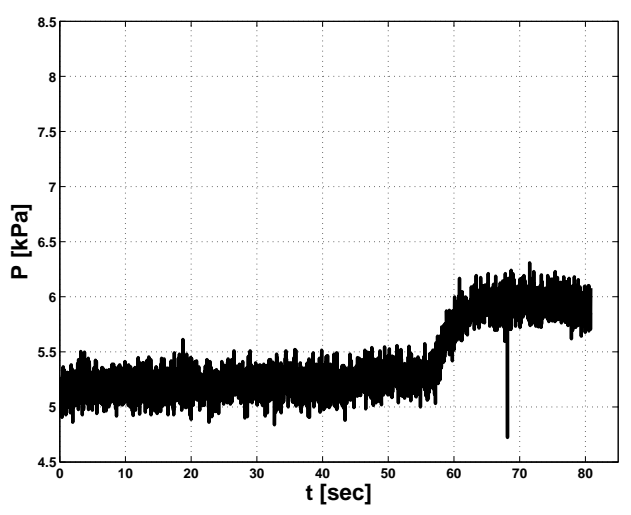

(b) $55.16 \mathrm{kPa}$ Compression

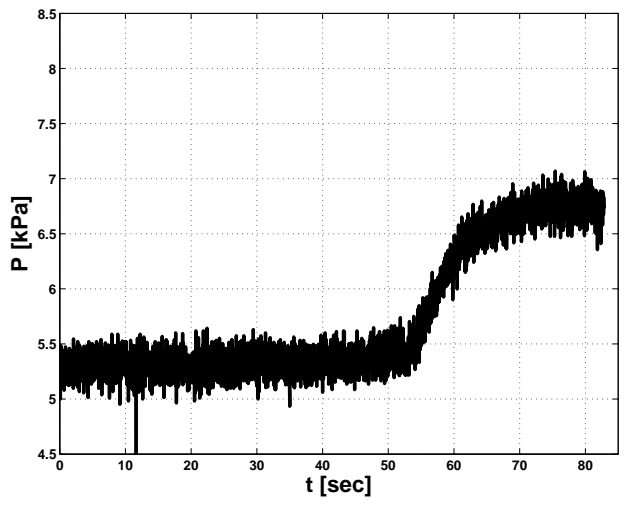

(d) $96.53 \mathrm{kPa}$ Compression

Figure E.2. Percolation pressure for Process 1. The tests were conducted at three different compressions on the sample $41.37 \mathrm{kPa}, 55.16 \mathrm{kPa}, 82.74 \mathrm{kPa}$, $96.53 \mathrm{kPa}$ while holding the flow rate constant at $18.75 \mathrm{E}-4 \mathrm{mLs}^{-1}$. 


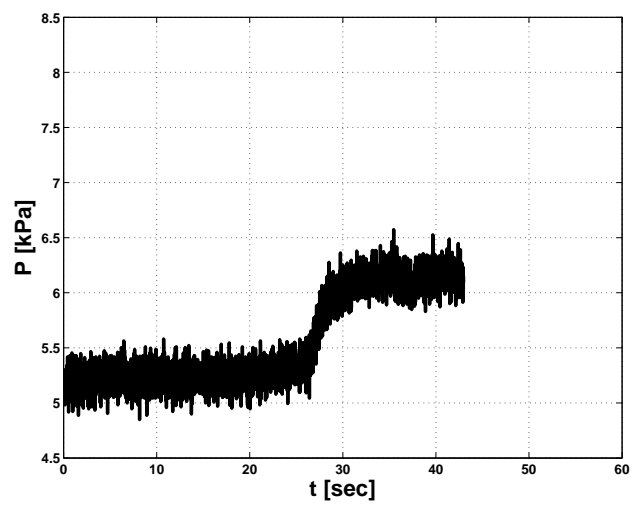

(a) $41.37 \mathrm{kPa}$ Compression

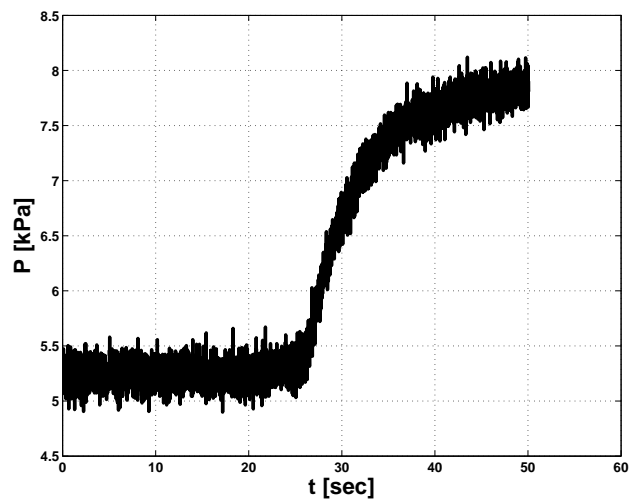

(c) $82.74 \mathrm{kPa}$ Compression

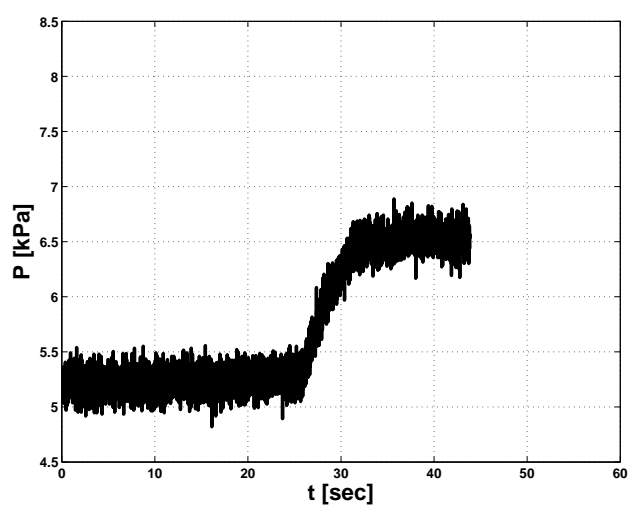

(b) $55.16 \mathrm{kPa}$ Compression

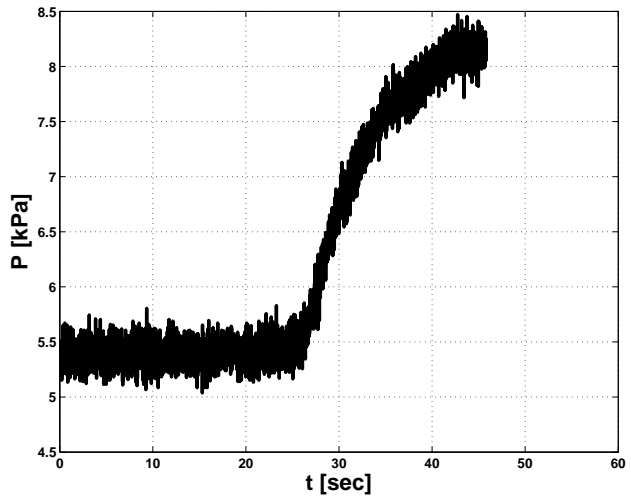

(d) $96.53 \mathrm{kPa}$ Compression

Figure E.3. Percolation pressure for Process 1. The tests were conducted at three different compressions on the sample $41.37 \mathrm{kPa}, 55.16 \mathrm{kPa}, 82.74 \mathrm{kPa}$, $96.53 \mathrm{kPa}$ while holding the flow rate constant at $37.08 \mathrm{E}-4 \mathrm{mLs}^{-1}$. 


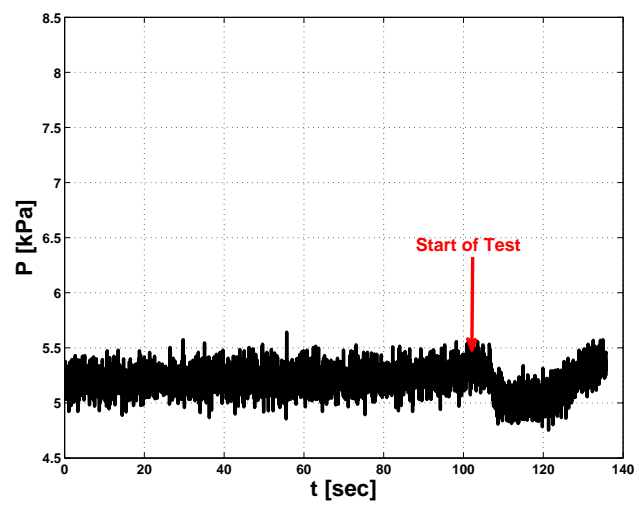

(a) $41.37 \mathrm{kPa}$ Compression

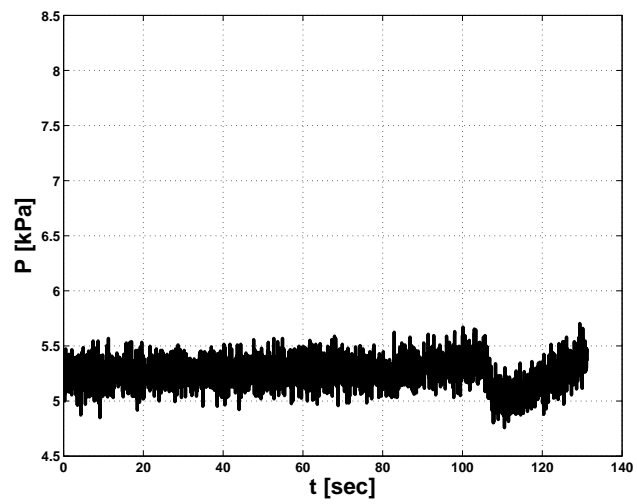

(c) $82.74 \mathrm{kPa}$ Compression

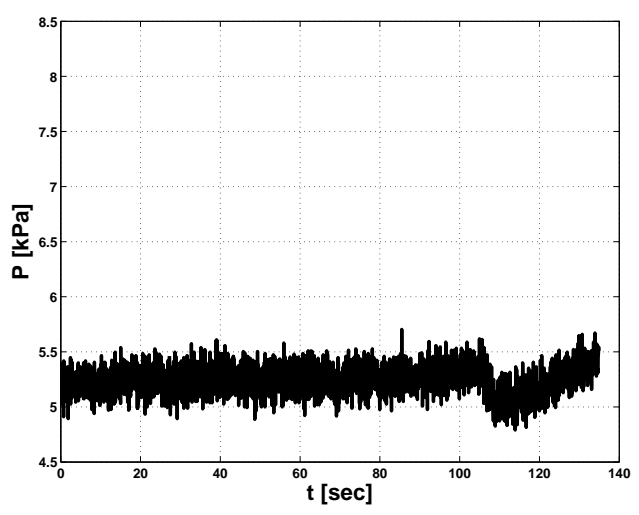

(b) $55.16 \mathrm{kPa}$ Compression

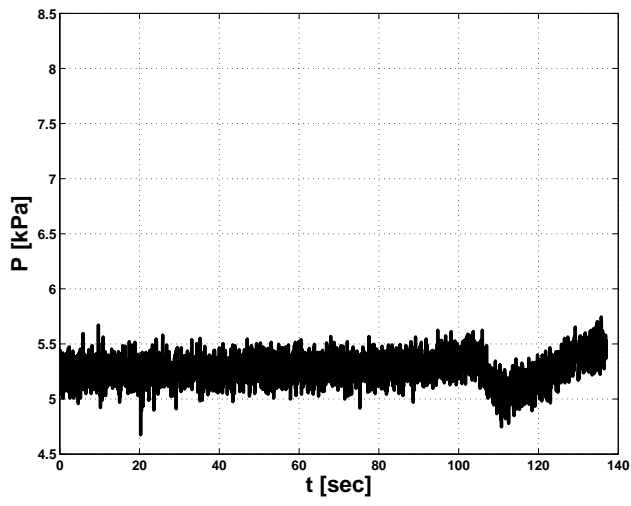

(d) $96.53 \mathrm{kPa}$ Compression

Figure E.4. Percolation pressure for Process 2. The tests were conducted at three different compressions on the sample $41.37 \mathrm{kPa}, 55.16 \mathrm{kPa}, 82.74 \mathrm{kPa}$, $96.53 \mathrm{kPa}$ while holding the flow rate constant at $9.48 \mathrm{E}-4 \mathrm{mLs}^{-1}$. 


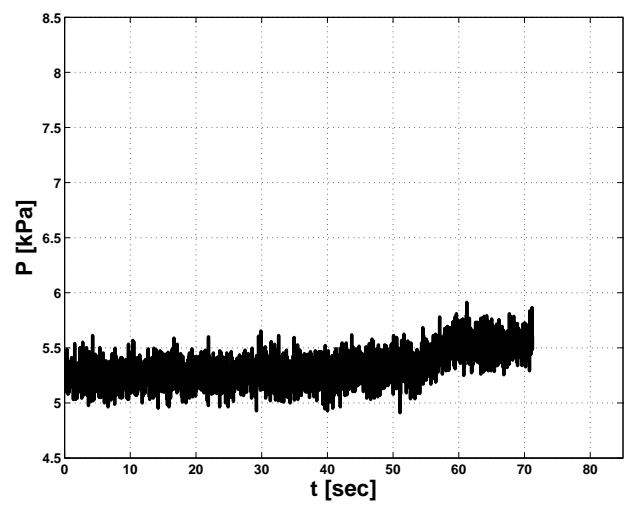

(a) $41.37 \mathrm{kPa}$ Compression

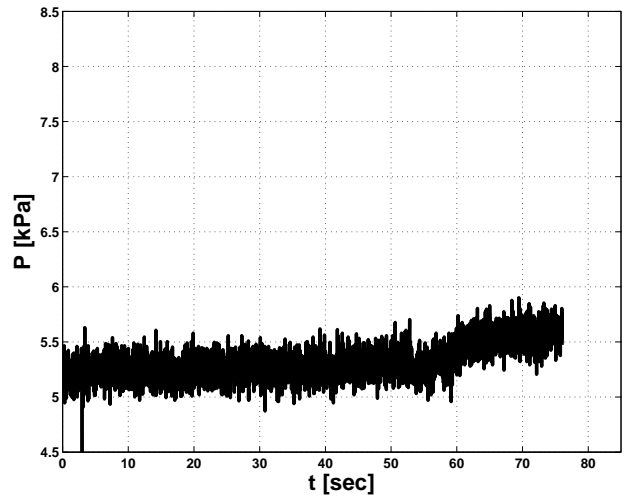

(c) $82.74 \mathrm{kPa}$ Compression

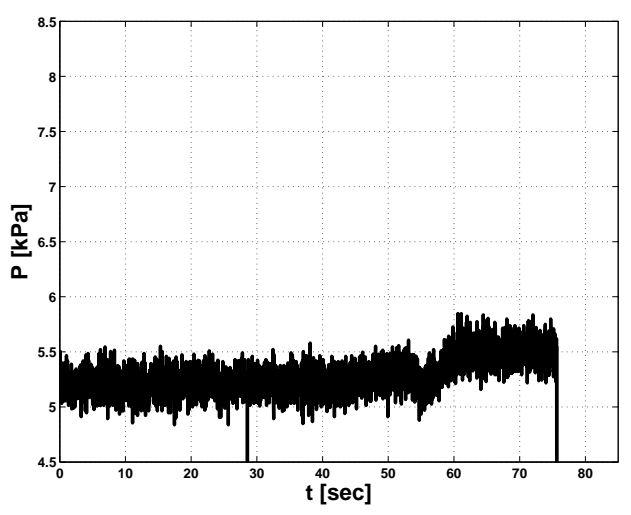

(b) $55.16 \mathrm{kPa}$ Compression

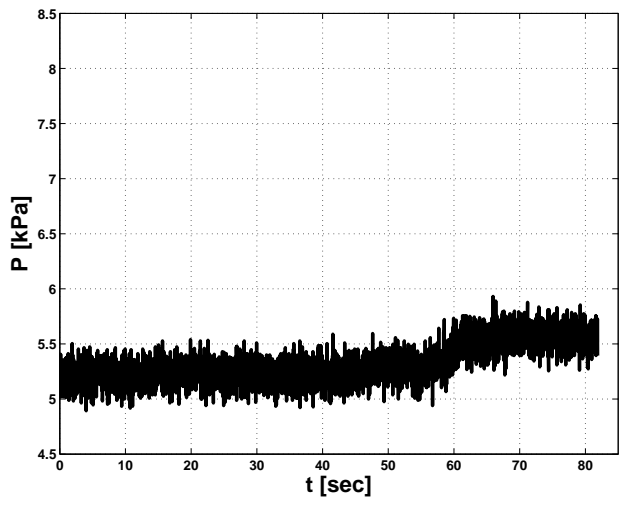

(d) $96.53 \mathrm{kPa}$ Compression

Figure E.5. Percolation pressure for Process 2. The tests were conducted at three different compressions on the sample $41.37 \mathrm{kPa}, 55.16 \mathrm{kPa}, 82.74 \mathrm{kPa}$, $96.53 \mathrm{kPa}$ while holding the flow rate constant at $18.75 \mathrm{E}-4 \mathrm{mLs}^{-1}$. 


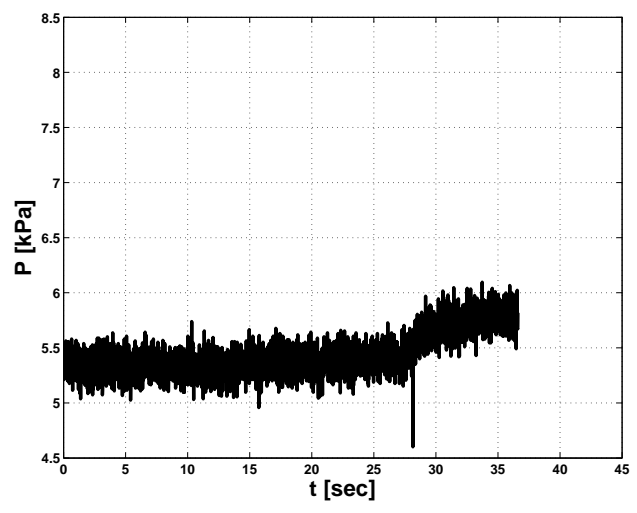

(a) $41.37 \mathrm{kPa}$ Compression

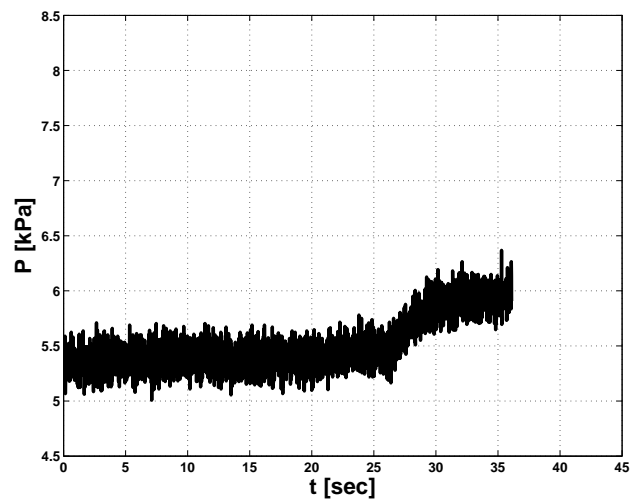

(c) $82.74 \mathrm{kPa}$ Compression

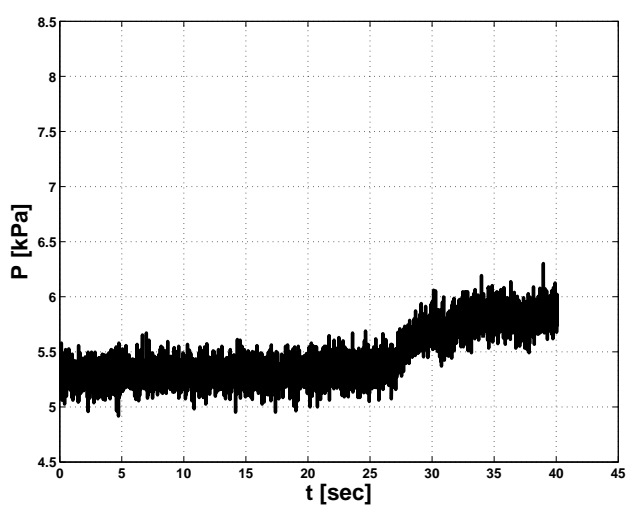

(b) $55.16 \mathrm{kPa}$ Compression

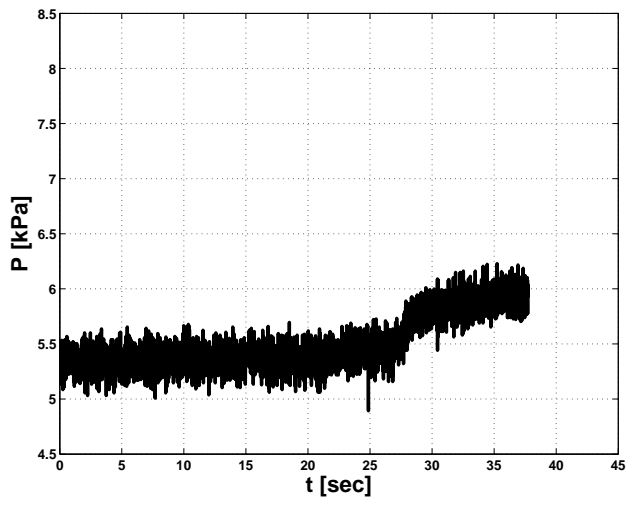

(d) $96.53 \mathrm{kPa}$ Compression

Figure E.6. Percolation pressure for Process 2. The tests were conducted at three different compressions on the sample $41.37 \mathrm{kPa}, 55.16 \mathrm{kPa}, 82.74 \mathrm{kPa}$, $96.53 \mathrm{kPa}$ while holding the flow rate constant at $37.08 \mathrm{E}-4 \mathrm{mLs}^{-1}$. 


\section{F. Full CCM Percolation Pressure Plots}




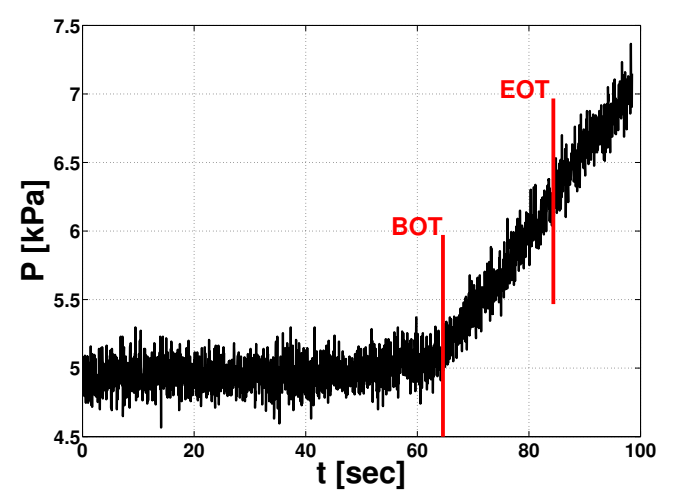

(a) $1^{\text {st }}$ test at $41.37 \mathrm{kPa}$.

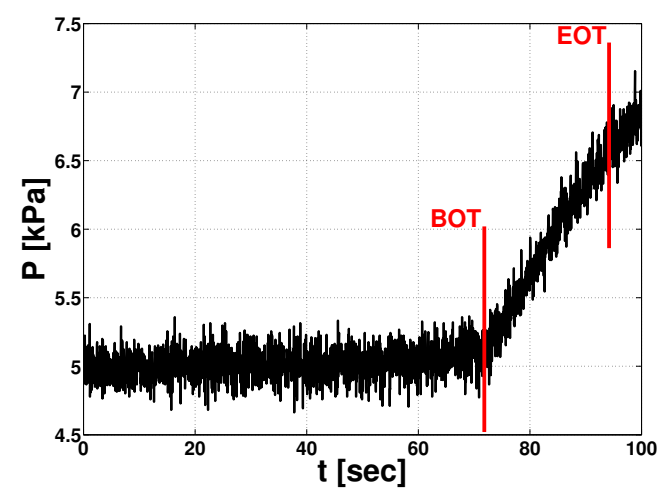

(c) $1^{\text {st }}$ test at $68.95 \mathrm{kPa}$.

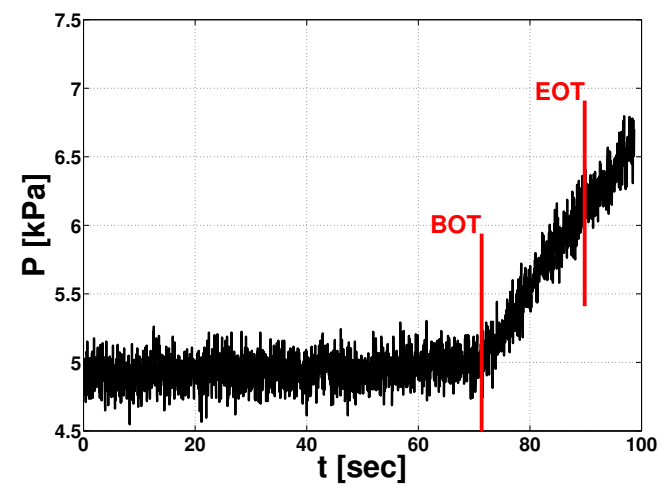

(e) $1^{\text {st }}$ test at $96.53 \mathrm{kPa}$.

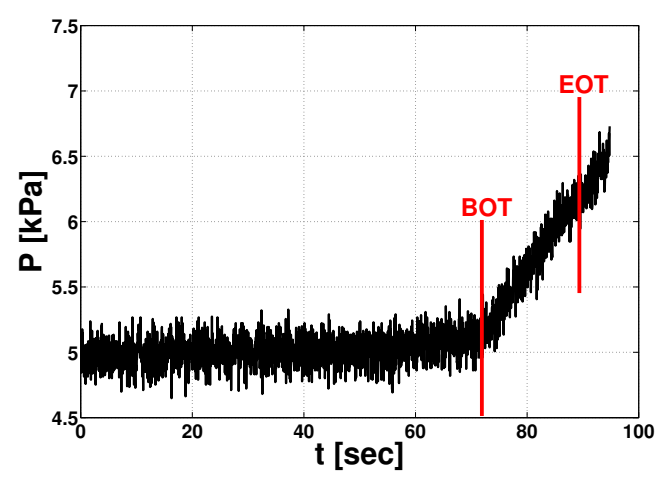

(b) $1^{\text {st }}$ test at $41.37 \mathrm{kPa}$.

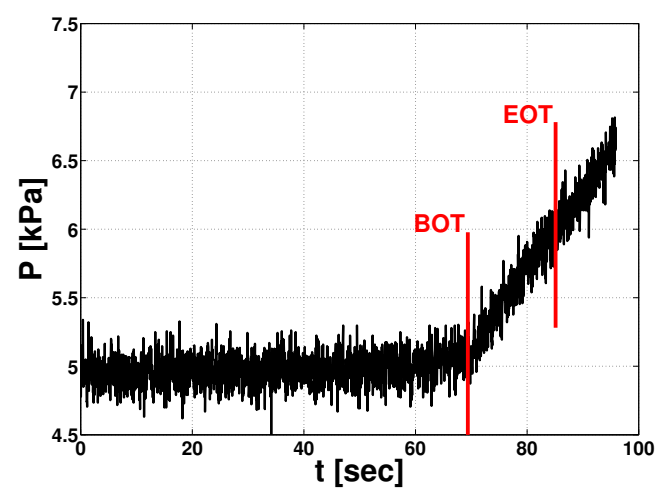

(d) $2^{\text {nd }}$ test at $68.95 \mathrm{kPa}$.

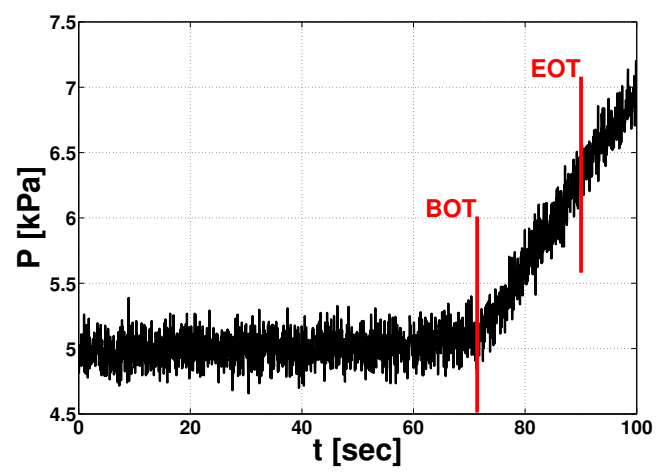

(f) $2^{\text {nd }}$ test at $96.53 \mathrm{kPa}$.

Figure F.1. Percolation pressure for VD420. The tests were conducted at three different compressions on the sample $41.37 \mathrm{kPa}, 68.95 \mathrm{kPa}, 96.53 \mathrm{kPa}$ while holding the flow rate constant at $9.48 \mathrm{E}-4 \mathrm{mLs}^{-1}$. 


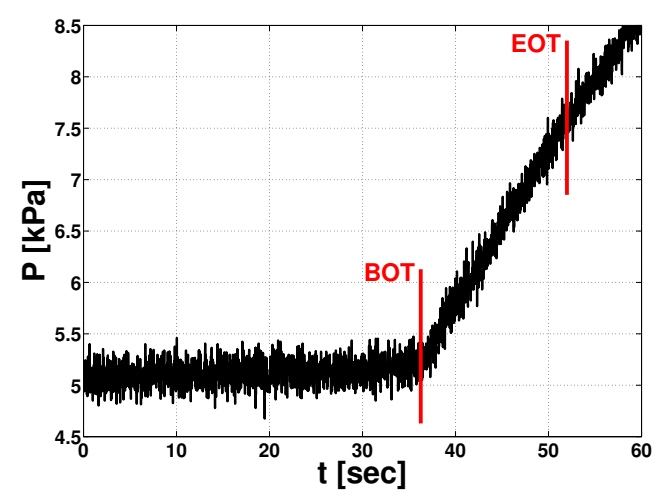

(a) $1^{\text {st }}$ test at $41.37 \mathrm{kPa}$.

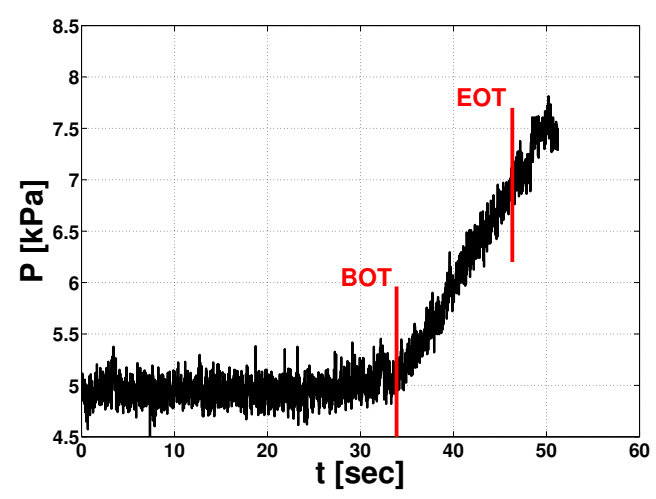

(c) $1^{\text {st }}$ test at $68.95 \mathrm{kPa}$.

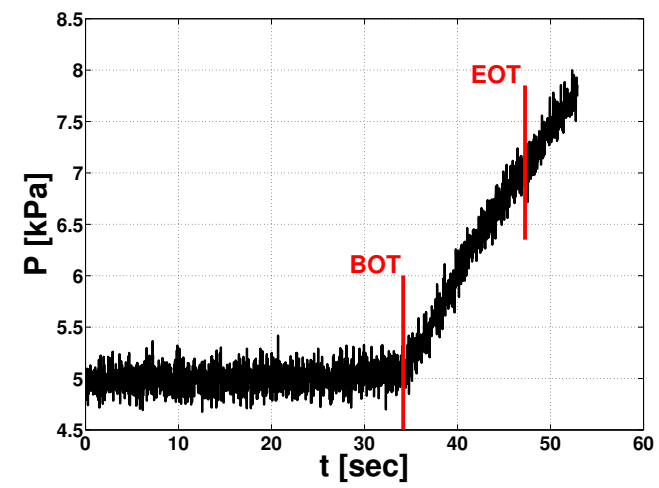

(e) $1^{\text {st }}$ test at $96.53 \mathrm{kPa}$.

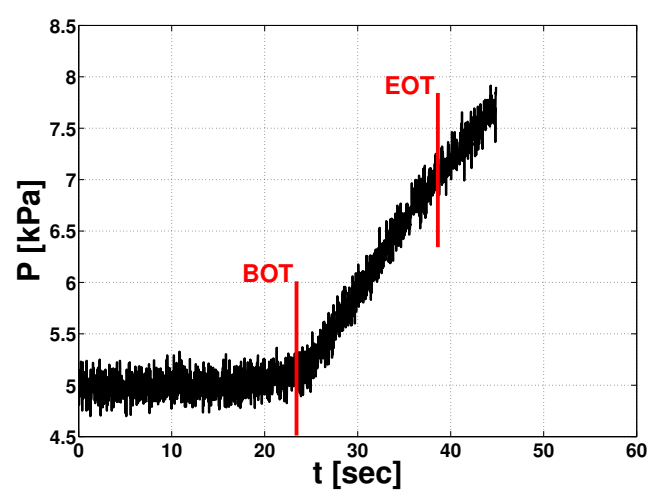

(b) $1^{\text {st }}$ test at $41.37 \mathrm{kPa}$.

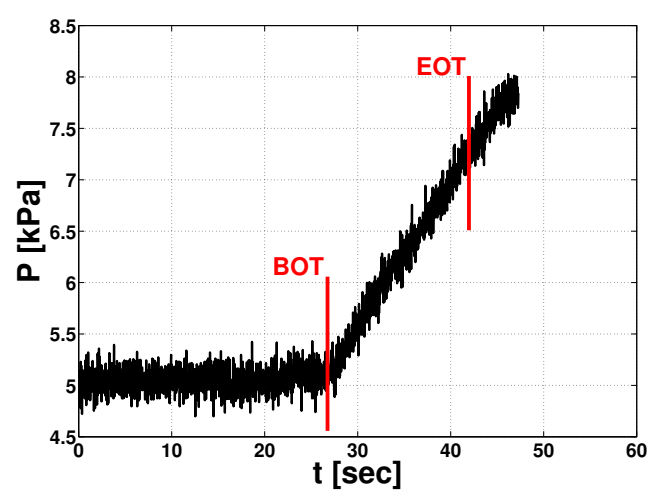

(d) $2^{\text {nd }}$ test at $68.95 \mathrm{kPa}$.

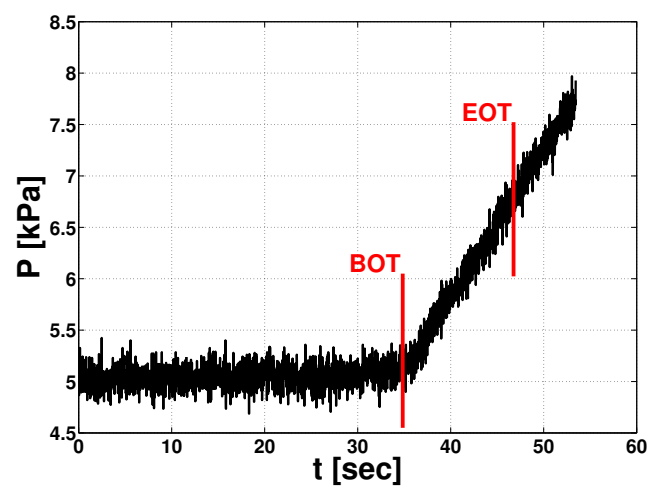

(f) $2^{\text {nd }}$ test at $96.53 \mathrm{kPa}$.

Figure F.2. Percolation pressure for VD420. The tests were conducted at three different compressions on the sample $41.37 \mathrm{kPa}, 68.95 \mathrm{kPa}, 96.53 \mathrm{kPa}$ while holding the flow rate constant at $18.75 \mathrm{E}-4 \mathrm{mLs}^{-1}$. 


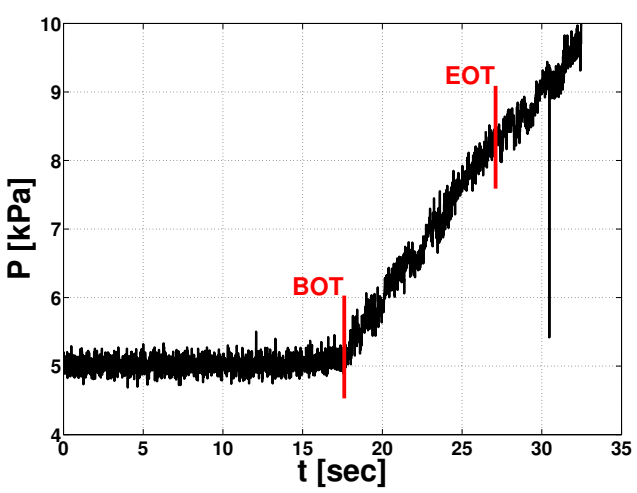

(a) $1^{\text {st }}$ test at $41.37 \mathrm{kPa}$.

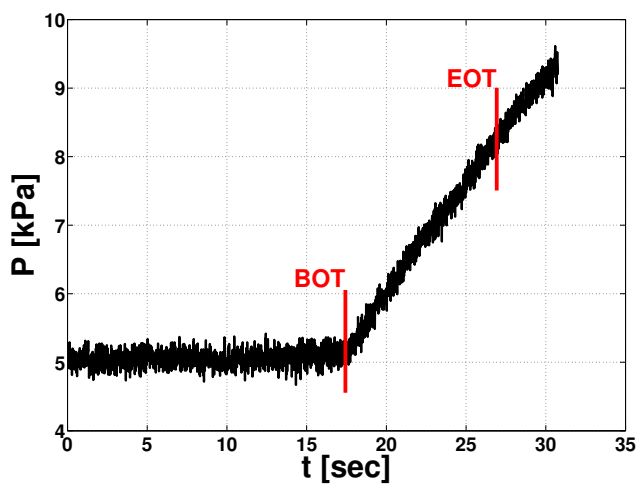

(c) $1^{\text {st }}$ test at $68.95 \mathrm{kPa}$.

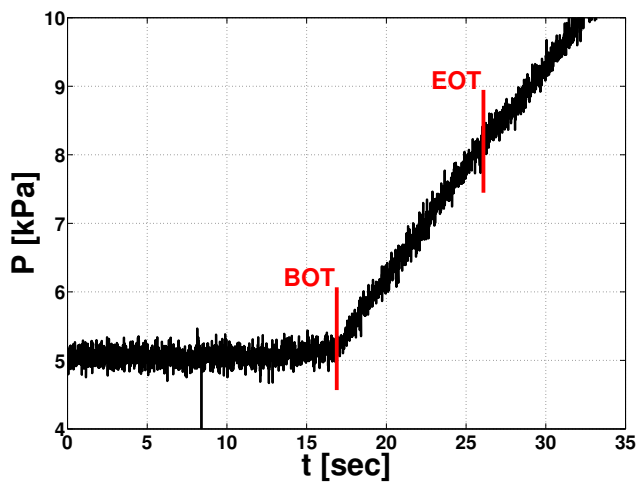

(e) $1^{\text {st }}$ test at $96.53 \mathrm{kPa}$.

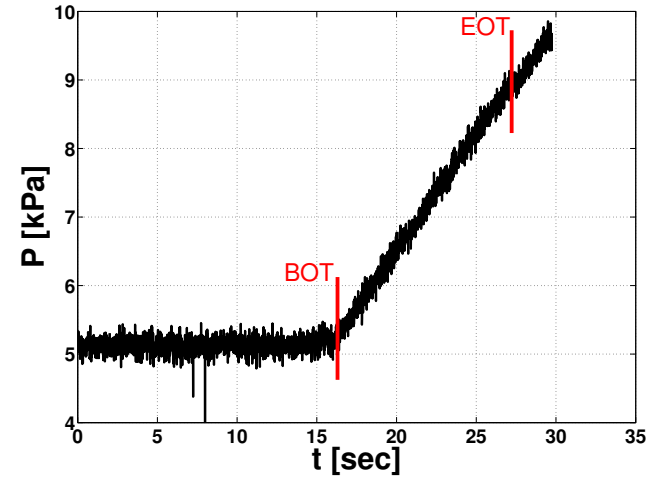

(b) $1^{\text {st }}$ test at $41.37 \mathrm{kPa}$.

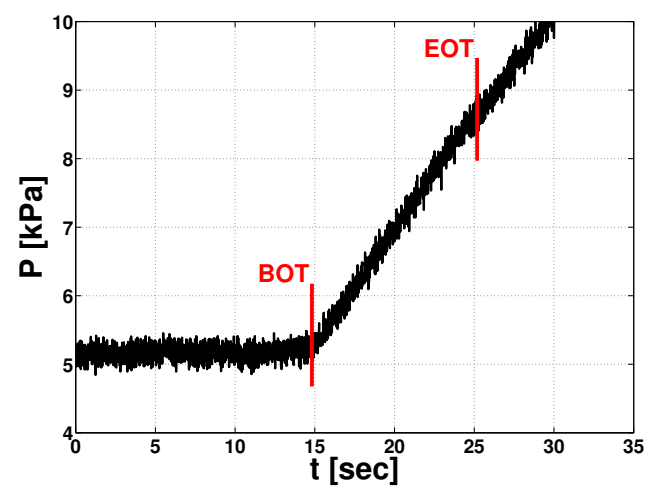

(d) $2^{\text {nd }}$ test at $68.95 \mathrm{kPa}$.

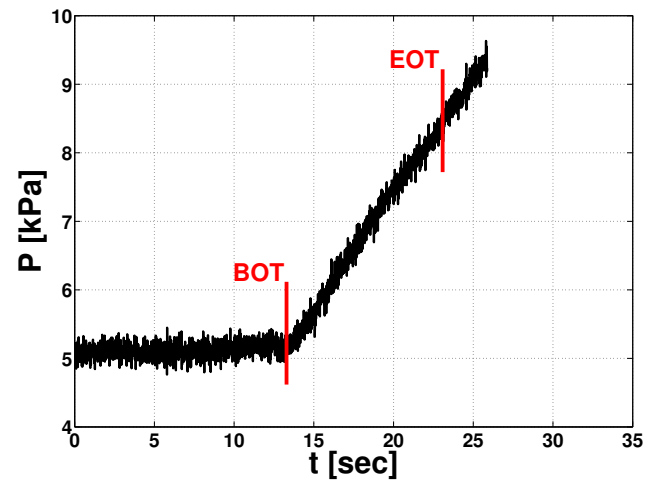

(f) $2^{\text {nd }}$ test at $96.53 \mathrm{kPa}$.

Figure F.3. Percolation pressure for VD420. The tests were conducted at three different compressions on the sample $41.37 \mathrm{kPa}, 68.95 \mathrm{kPa}, 96.53 \mathrm{kPa}$ while holding the flow rate constant at $37.08 \mathrm{E}-4 \mathrm{mLs}^{-1}$. 


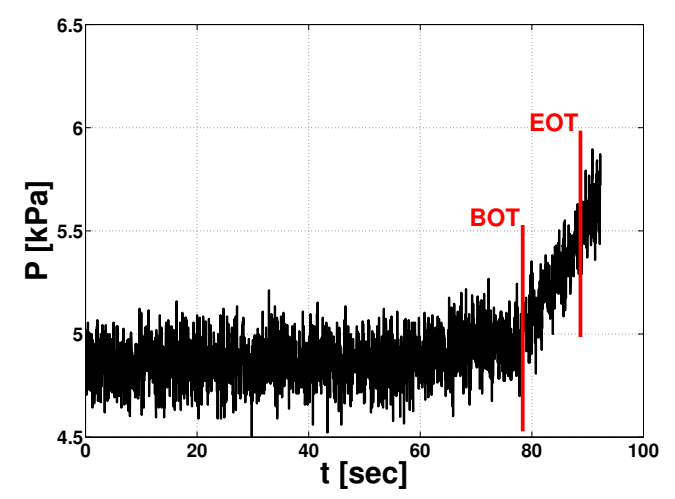

(a) $1^{\text {st }}$ test at $41.37 \mathrm{kPa}$.

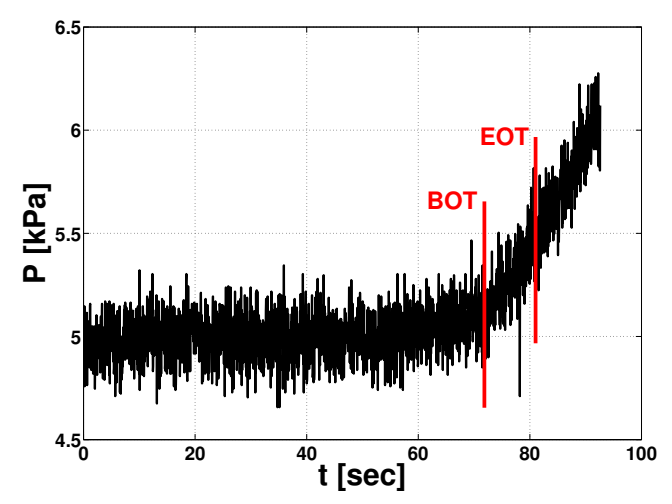

(c) $1^{\text {st }}$ test at $68.95 \mathrm{kPa}$.

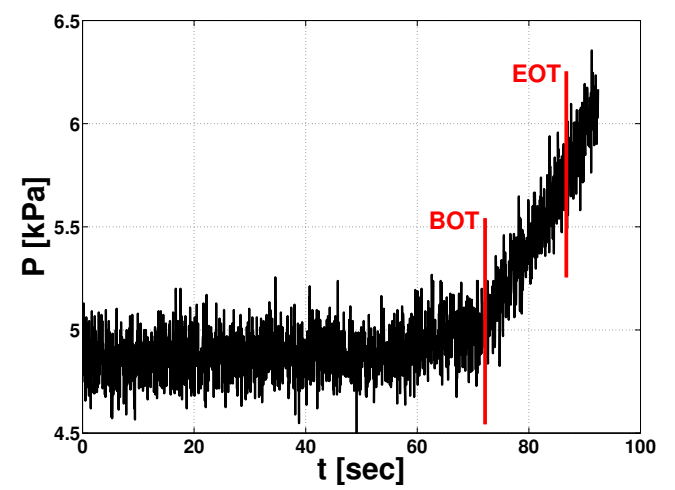

(e) $1^{\text {st }}$ test at $96.53 \mathrm{kPa}$.

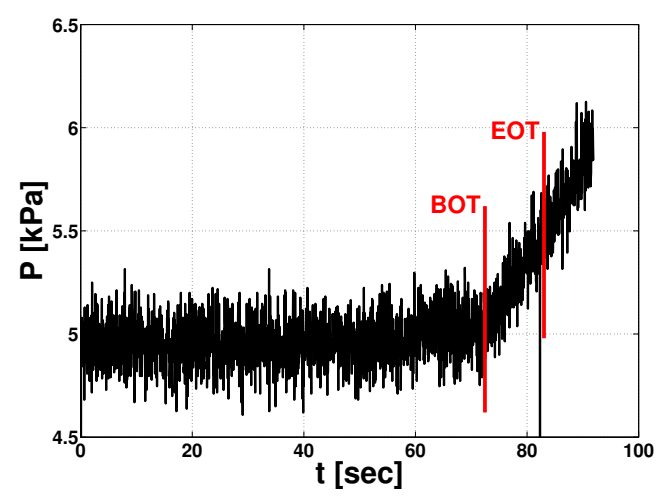

(b) $1^{\text {st }}$ test at $41.37 \mathrm{kPa}$.

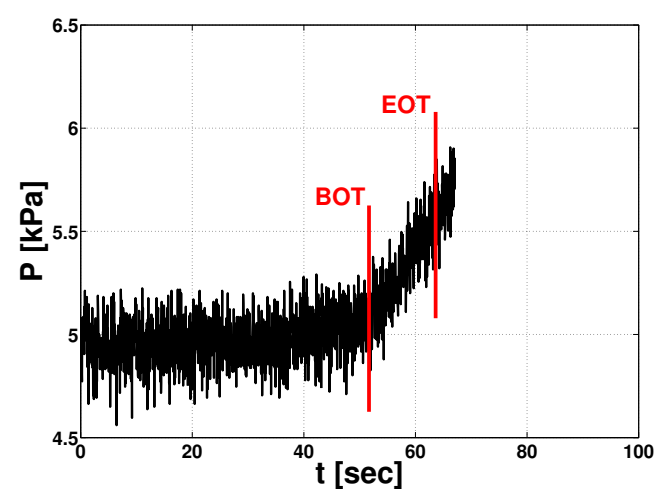

(d) $2^{\text {nd }}$ test at $68.95 \mathrm{kPa}$.

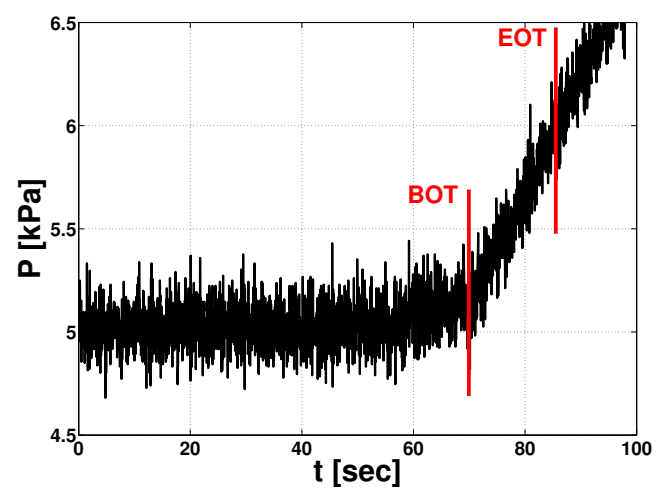

(f) $2^{\text {nd }}$ test at $96.53 \mathrm{kPa}$.

Figure F.4. Percolation pressure for VD421. The tests were conducted at three different compressions on the sample $41.37 \mathrm{kPa}, 68.95 \mathrm{kPa}, 96.53 \mathrm{kPa}$ while holding the flow rate constant at $9.48 \mathrm{E}-4 \mathrm{mLs}^{-1}$. 


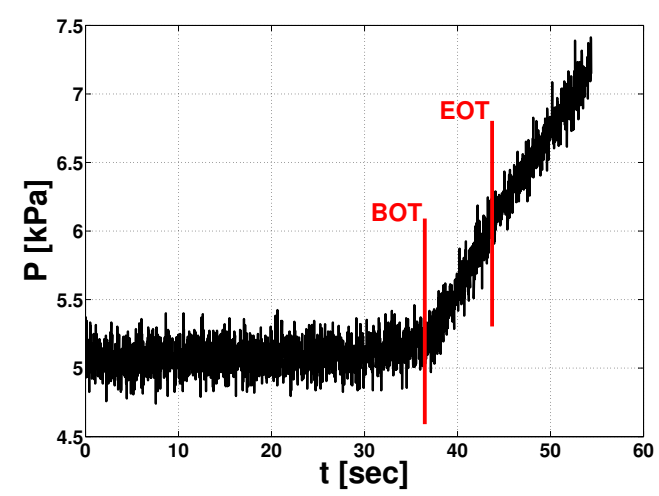

(a) $1^{\text {st }}$ test at $41.37 \mathrm{kPa}$.

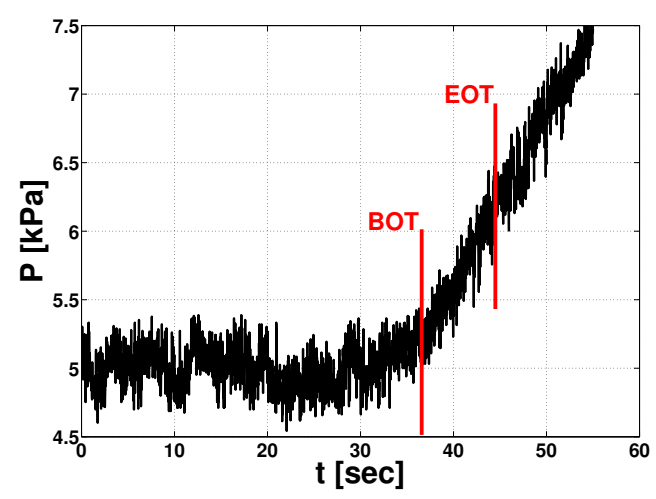

(c) $1^{\text {st }}$ test at $68.95 \mathrm{kPa}$.

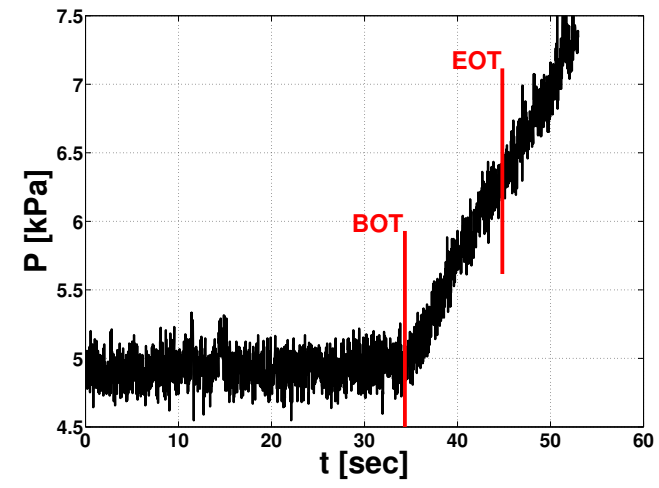

(e) $1^{\text {st }}$ test at $96.53 \mathrm{kPa}$.

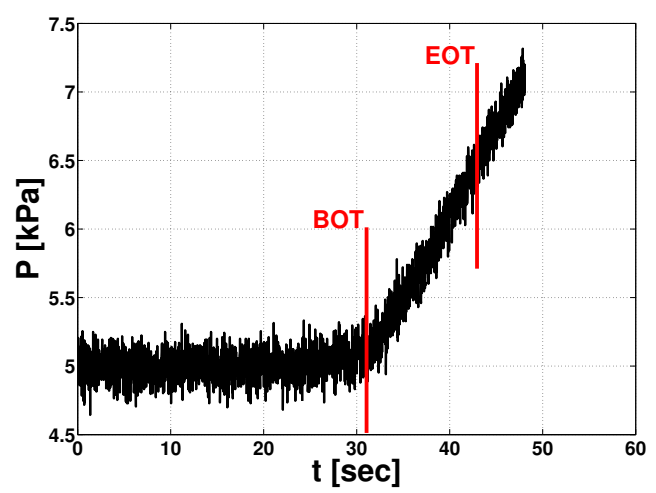

(b) $1^{\text {st }}$ test at $41.37 \mathrm{kPa}$.

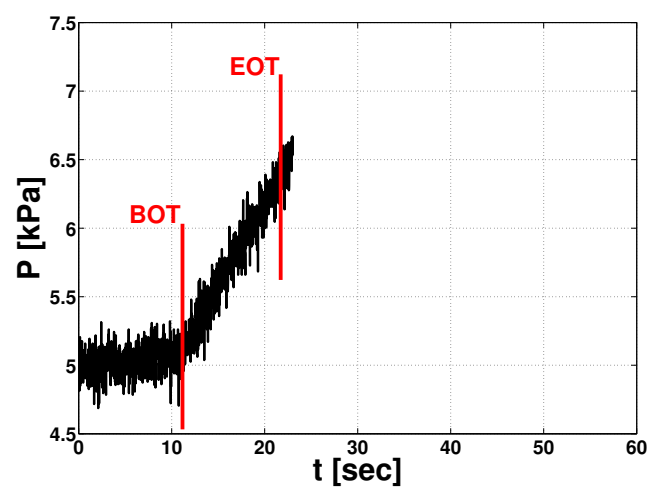

(d) $2^{\text {nd }}$ test at $68.95 \mathrm{kPa}$.

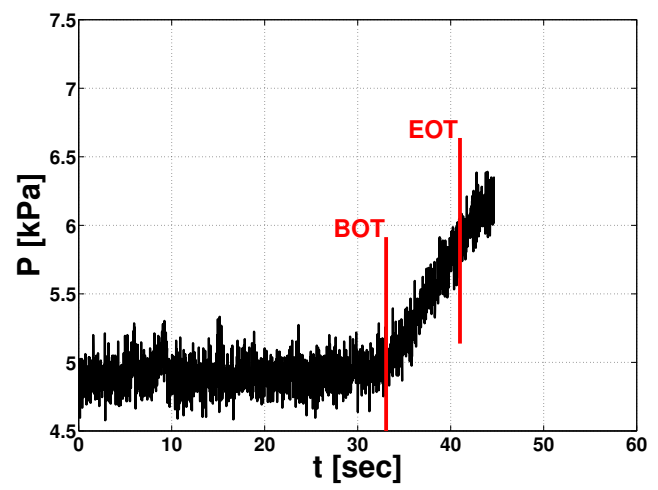

(f) $2^{\text {nd }}$ test at $96.53 \mathrm{kPa}$.

Figure F.5. Percolation pressure for VD421. The tests were conducted at three different compressions on the sample $41.37 \mathrm{kPa}, 68.95 \mathrm{kPa}, 96.53 \mathrm{kPa}$ while holding the flow rate constant at $18.75 \mathrm{E}-4 \mathrm{mLs}^{-1}$. 


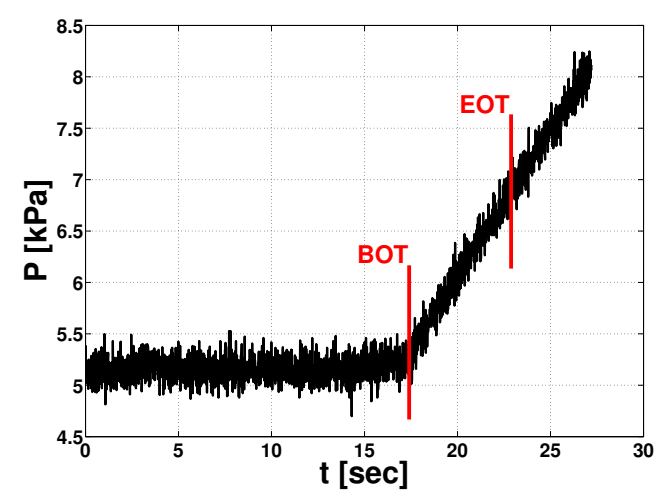

(a) $1^{\text {st }}$ test at $41.37 \mathrm{kPa}$.

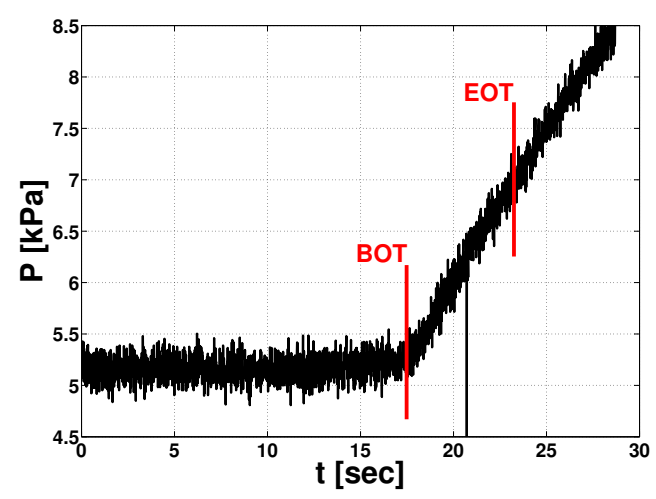

(c) $1^{\text {st }}$ test at $68.95 \mathrm{kPa}$.

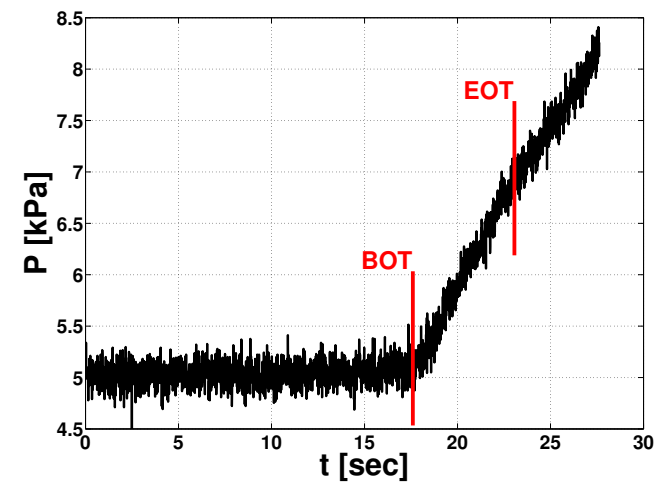

(e) $1^{\text {st }}$ test at $96.53 \mathrm{kPa}$.

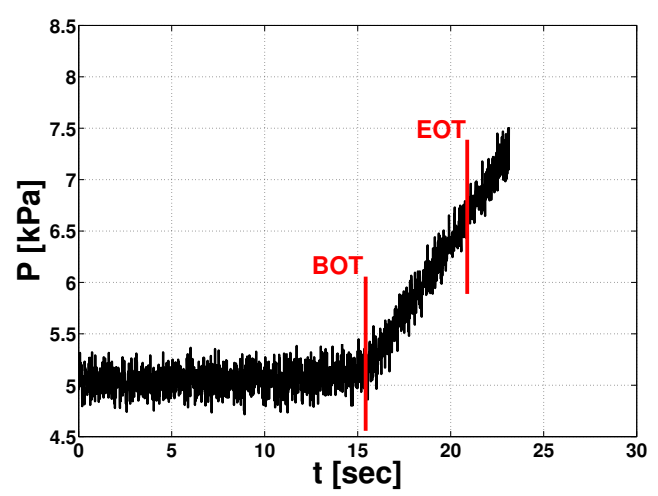

(b) $1^{\text {st }}$ test at $41.37 \mathrm{kPa}$.

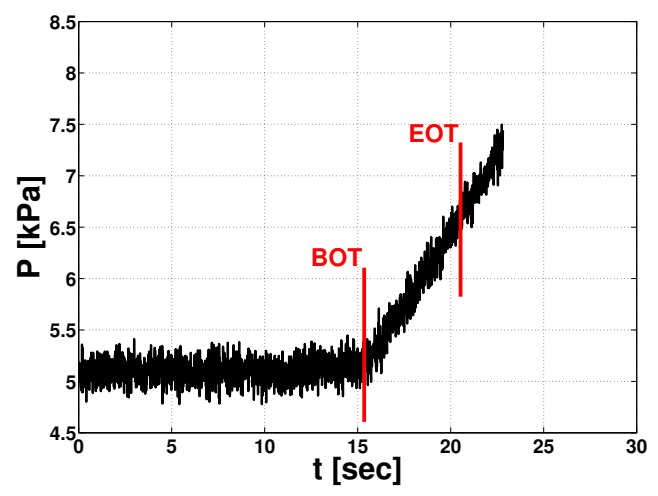

(d) $2^{\text {nd }}$ test at $68.95 \mathrm{kPa}$.

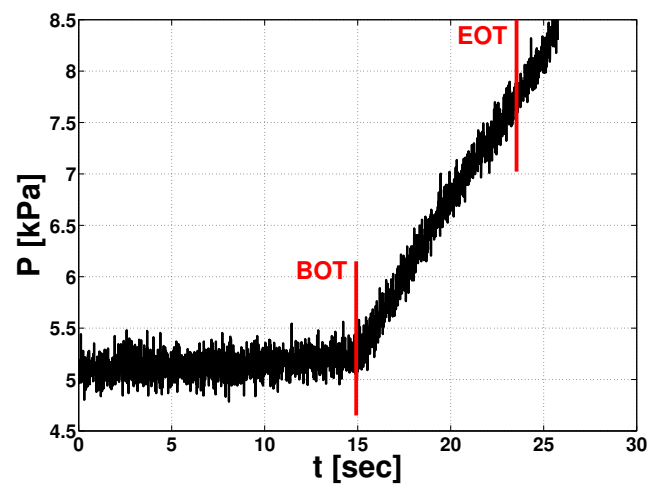

(f) $2^{\text {nd }}$ test at $96.53 \mathrm{kPa}$.

Figure F.6. Percolation pressure for VD421. The tests were conducted at three different compressions on the sample $41.37 \mathrm{kPa}, 68.95 \mathrm{kPa}, 96.53 \mathrm{kPa}$ while holding the flow rate constant at $37.08 \mathrm{E}-4 \mathrm{mLs}^{-1}$. 


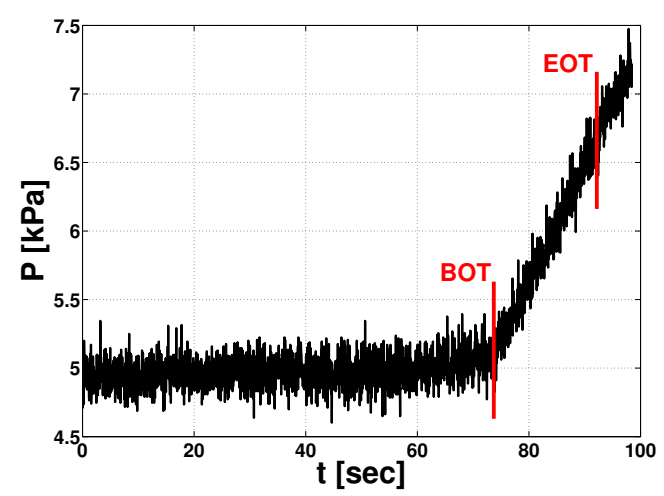

(a) $1^{\text {st }}$ test at $41.37 \mathrm{kPa}$.

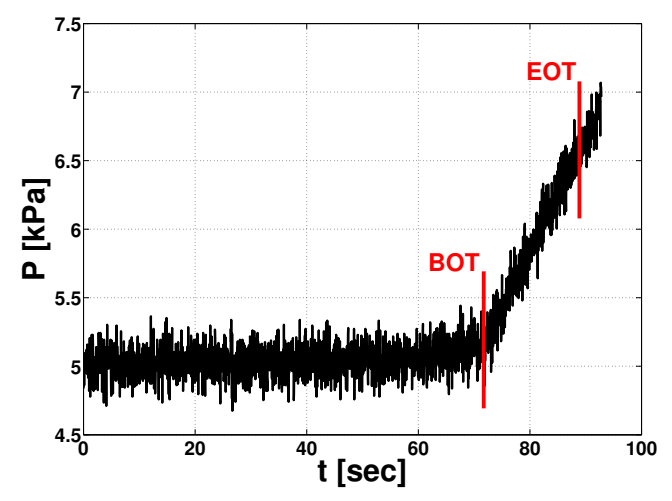

(c) $1^{\text {st }}$ test at $68.95 \mathrm{kPa}$.

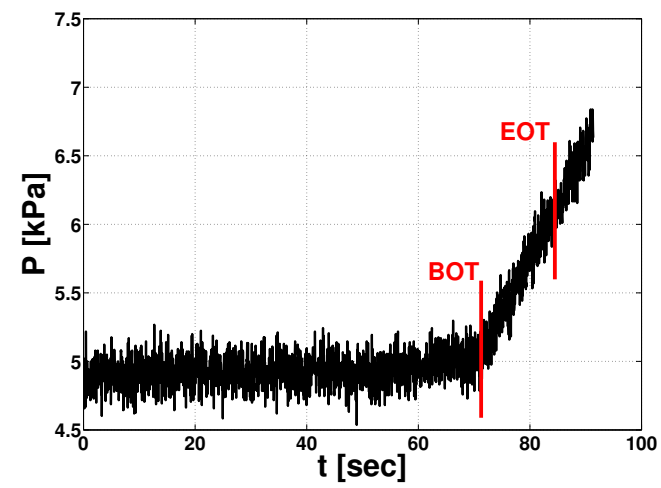

(e) $1^{\text {st }}$ test at $96.53 \mathrm{kPa}$.

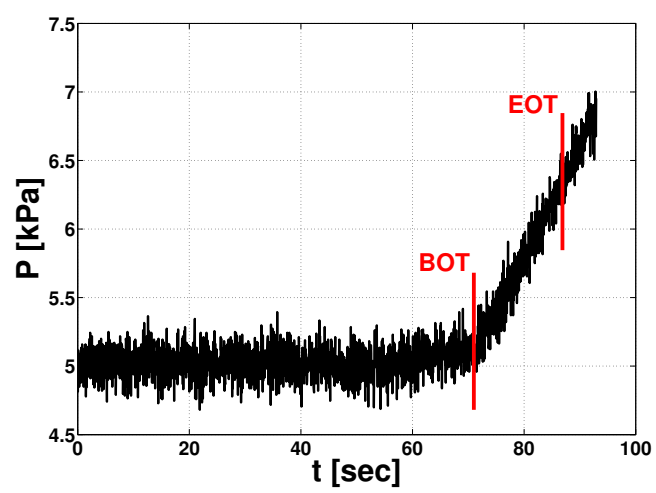

(b) $1^{\text {st }}$ test at $41.37 \mathrm{kPa}$.

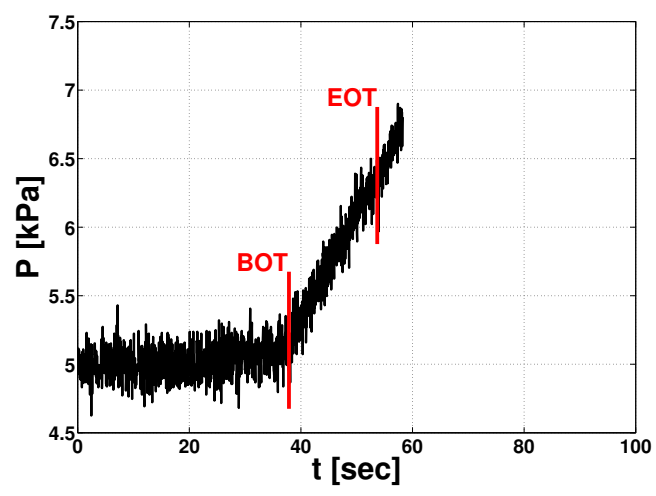

(d) $2^{\text {nd }}$ test at $68.95 \mathrm{kPa}$.

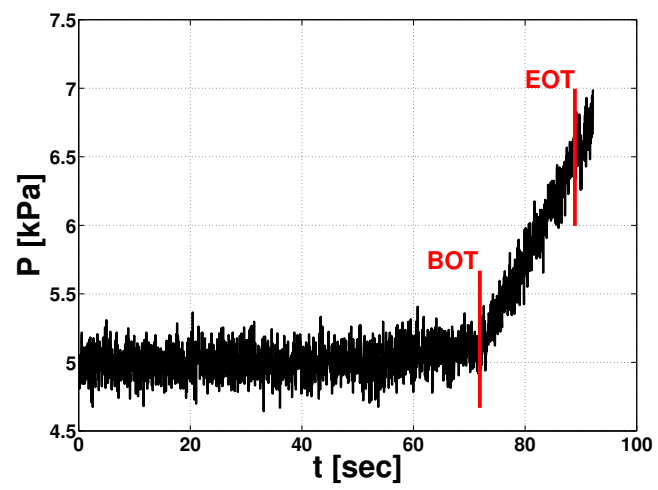

(f) $2^{\text {nd }}$ test at $96.53 \mathrm{kPa}$.

Figure F.7. Percolation pressure for VD423. The tests were conducted at three different compressions on the sample $41.37 \mathrm{kPa}, 68.95 \mathrm{kPa}, 96.53 \mathrm{kPa}$ while holding the flow rate constant at $9.48 \mathrm{E}-4 \mathrm{mLs}^{-1}$. 


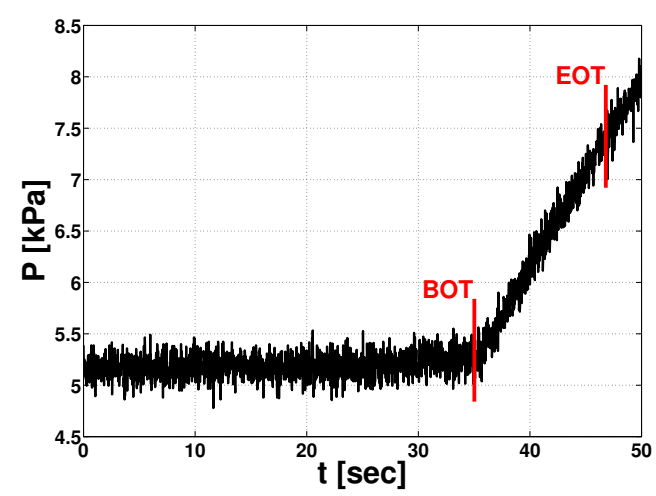

(a) $1^{\text {st }}$ test at $41.37 \mathrm{kPa}$.

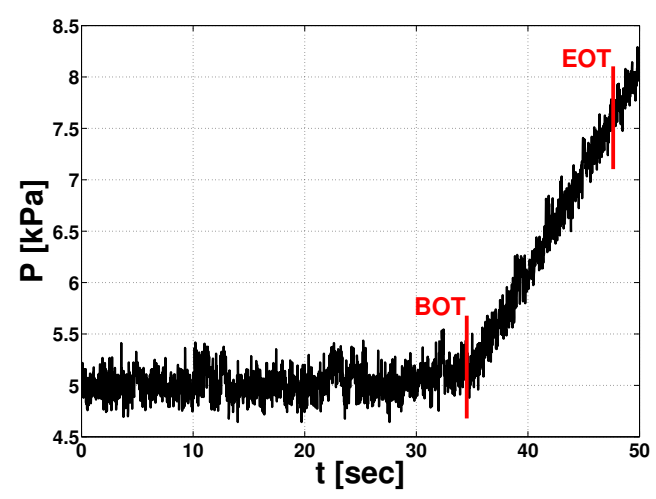

(c) $1^{\text {st }}$ test at $68.95 \mathrm{kPa}$.

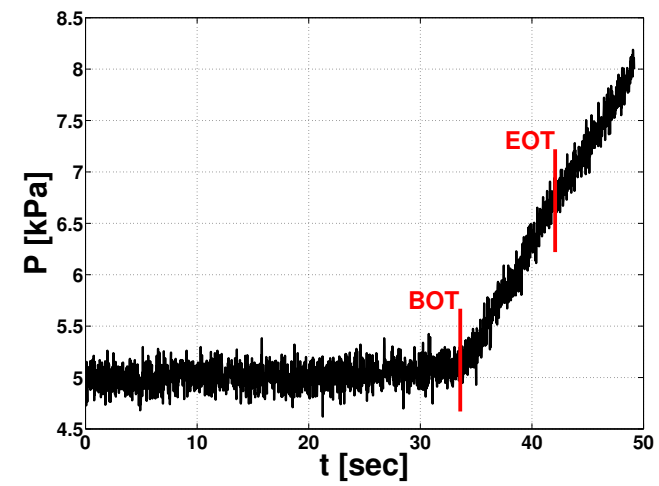

(e) $1^{\text {st }}$ test at $96.53 \mathrm{kPa}$.

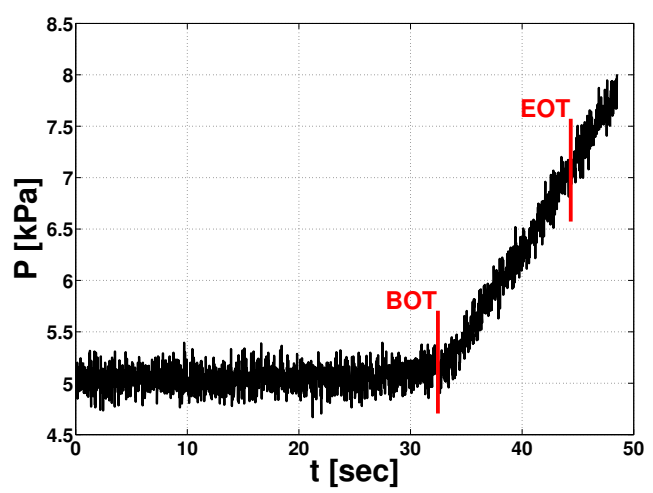

(b) $1^{\text {st }}$ test at $41.37 \mathrm{kPa}$.

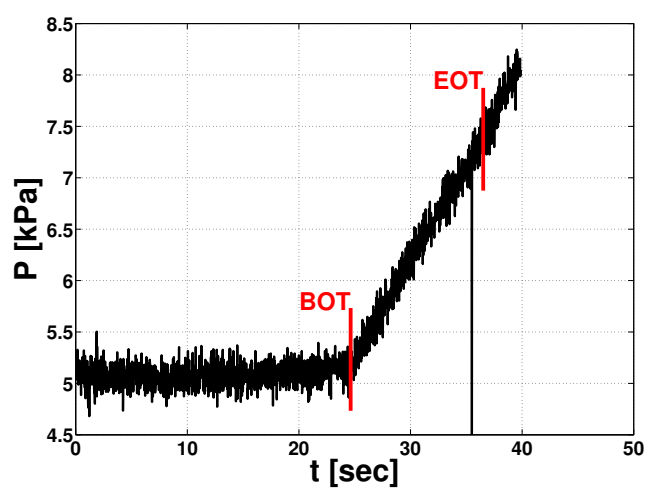

(d) $2^{\text {nd }}$ test at $68.95 \mathrm{kPa}$.

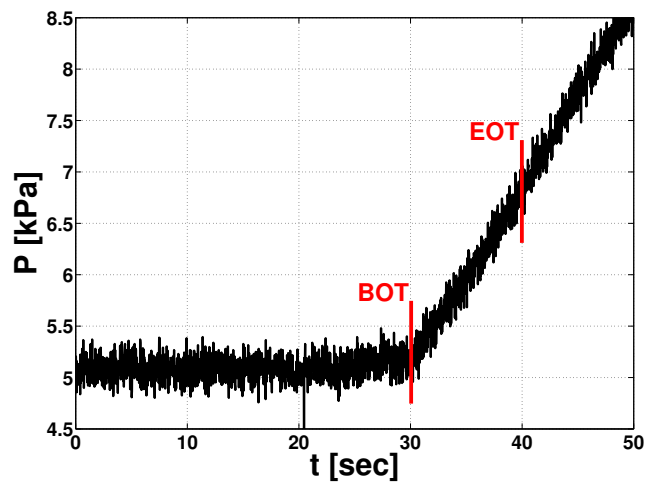

(f) $2^{\text {nd }}$ test at $96.53 \mathrm{kPa}$.

Figure F.8. Percolation pressure for VD423. The tests were conducted at three different compressions on the sample $41.37 \mathrm{kPa}, 68.95 \mathrm{kPa}, 96.53 \mathrm{kPa}$ while holding the flow rate constant at $18.75 \mathrm{E}-4 \mathrm{mLs}^{-1}$. 


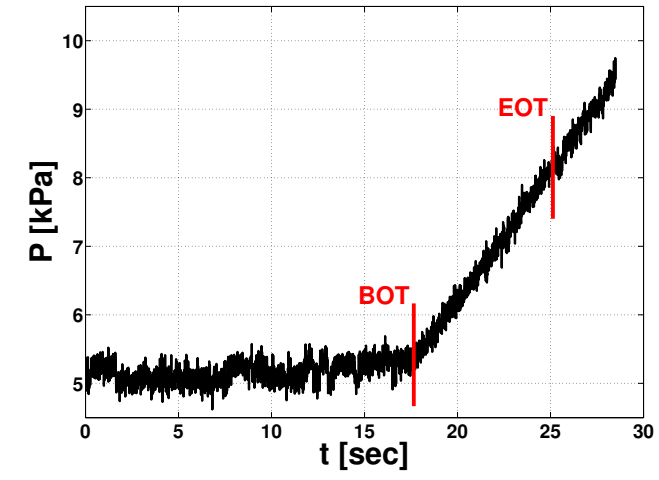

(a) $1^{\text {st }}$ test at $41.37 \mathrm{kPa}$.

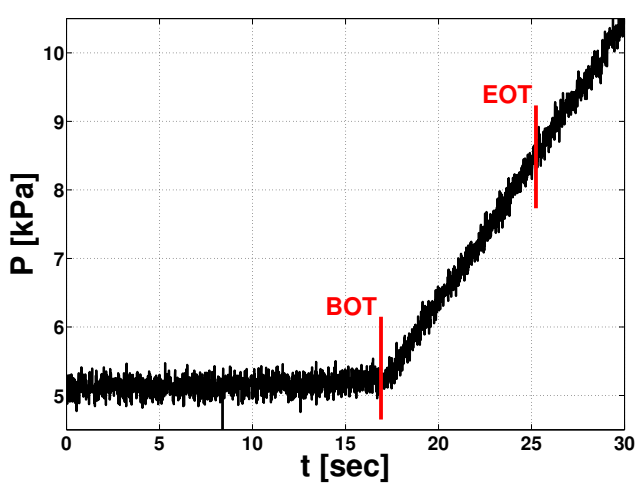

(c) $1^{\text {st }}$ test at $68.95 \mathrm{kPa}$.

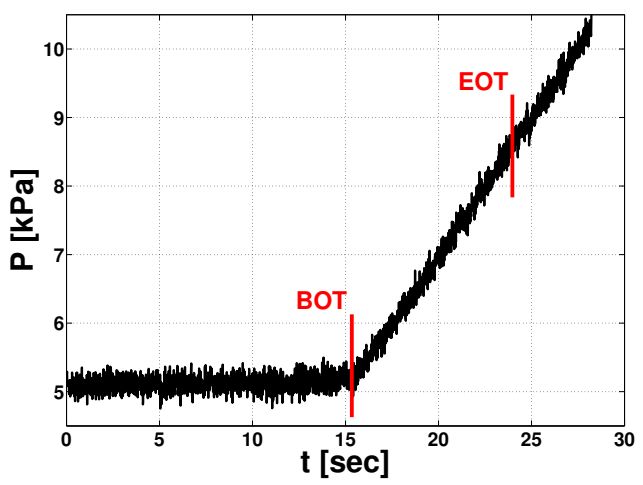

(e) $1^{\text {st }}$ test at $96.53 \mathrm{kPa}$.

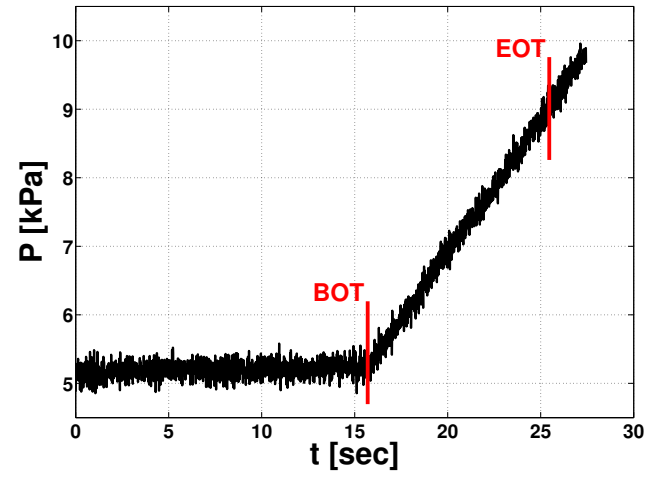

(b) $1^{\text {st }}$ test at $41.37 \mathrm{kPa}$.

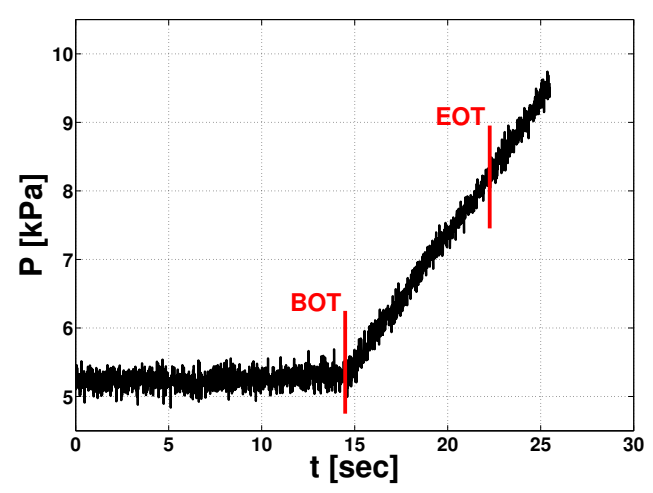

(d) $2^{\text {nd }}$ test at $68.95 \mathrm{kPa}$.

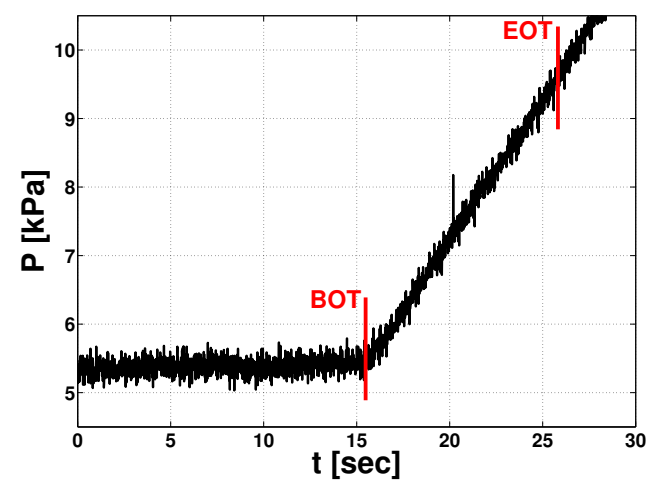

(f) $2^{\text {nd }}$ test at $96.53 \mathrm{kPa}$.

Figure F.9. Percolation pressure for VD423. The tests were conducted at three different compressions on the sample $41.37 \mathrm{kPa}, 68.95 \mathrm{kPa}, 96.53 \mathrm{kPa}$ while holding the flow rate constant at $37.08 \mathrm{E}-4 \mathrm{mLs}^{-1}$. 


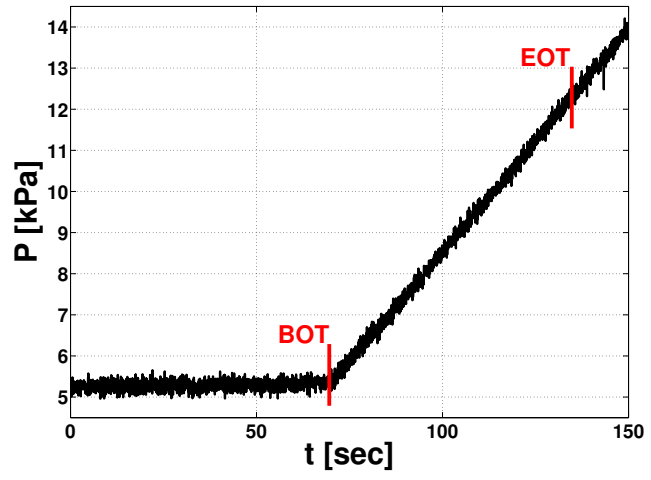

(a) $1^{\text {st }}$ test at $41.37 \mathrm{kPa}$.

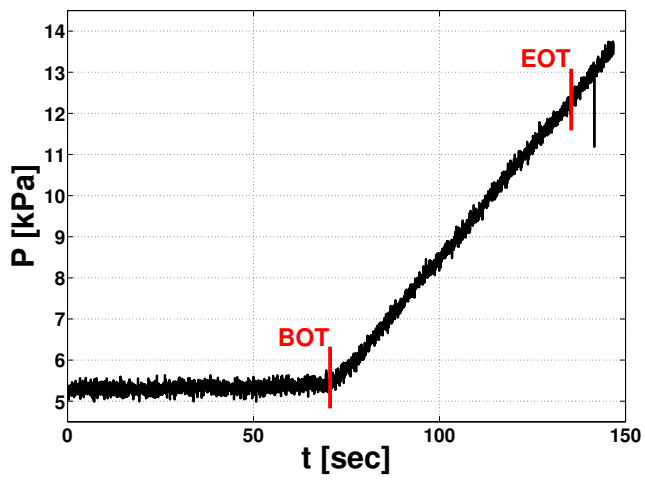

(c) $1^{\text {st }}$ test at $68.95 \mathrm{kPa}$.

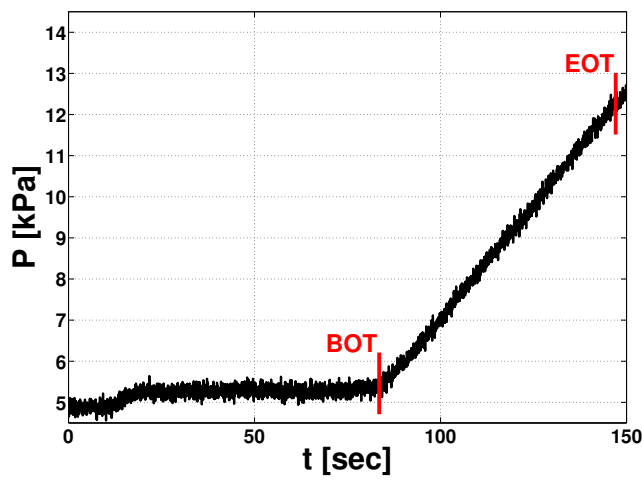

(e) $1^{\text {st }}$ test at $96.53 \mathrm{kPa}$.

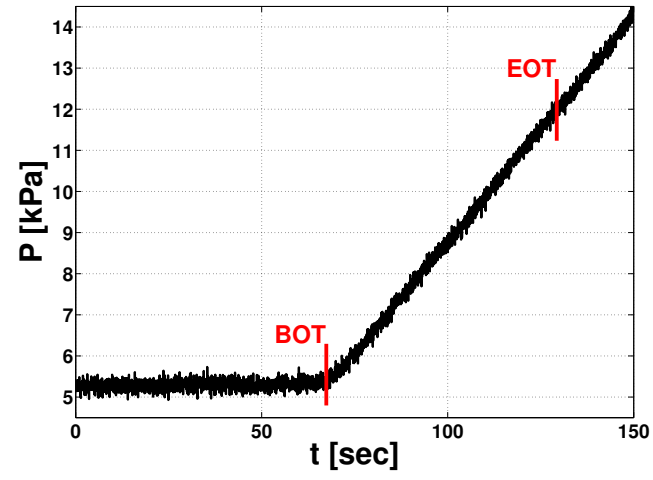

(b) $1^{\text {st }}$ test at $41.37 \mathrm{kPa}$.

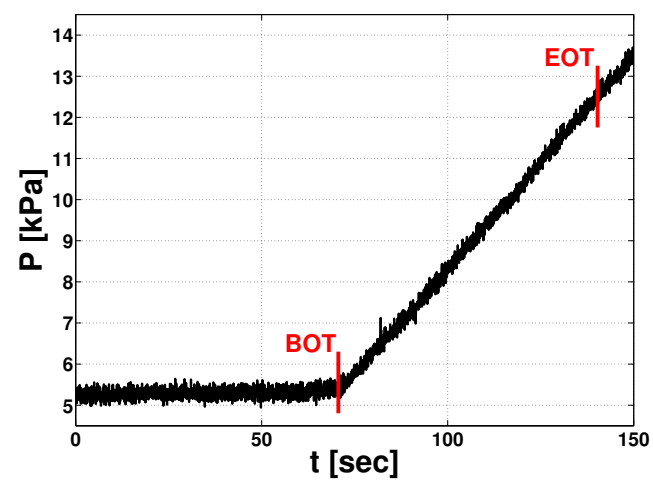

(d) $2^{\text {nd }}$ test at $68.95 \mathrm{kPa}$.

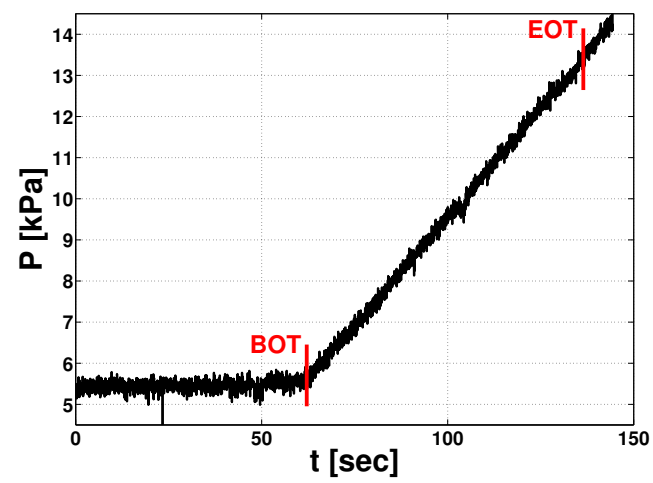

(f) $2^{\text {nd }}$ test at $96.53 \mathrm{kPa}$.

Figure F.10. Percolation pressure for VD422. The tests were conducted at three different compressions on the sample $41.37 \mathrm{kPa}, 68.95 \mathrm{kPa}, 96.53 \mathrm{kPa}$ while holding the flow rate constant at $9.48 \mathrm{E}-4 \mathrm{mLs}^{-1}$. 


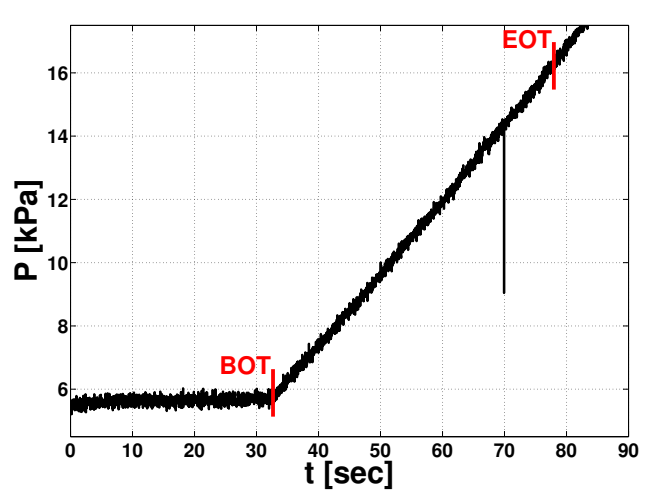

(a) $1^{\text {st }}$ test at $41.37 \mathrm{kPa}$.

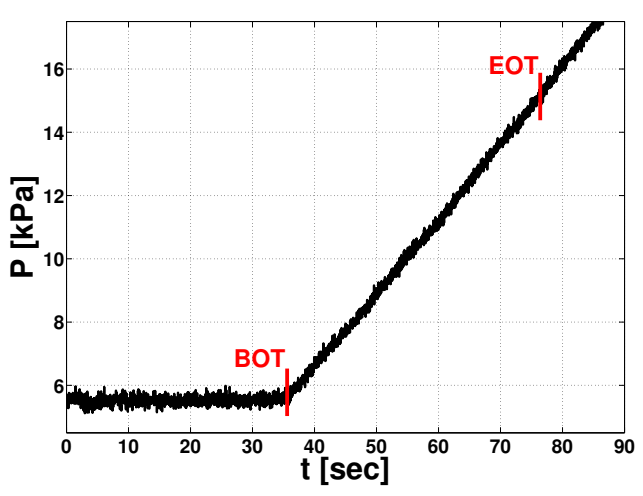

(c) $1^{\text {st }}$ test at $68.95 \mathrm{kPa}$.

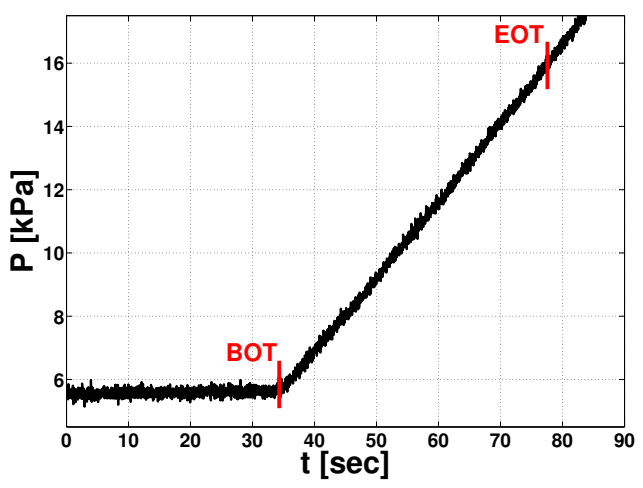

(e) $1^{\text {st }}$ test at $96.53 \mathrm{kPa}$.

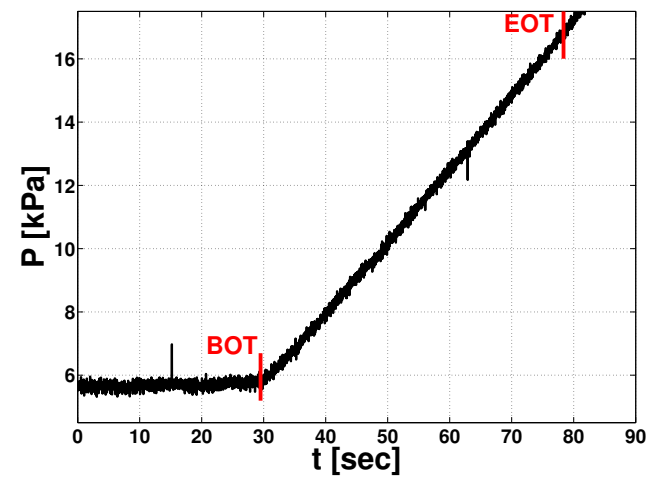

(b) $1^{\text {st }}$ test at $41.37 \mathrm{kPa}$.

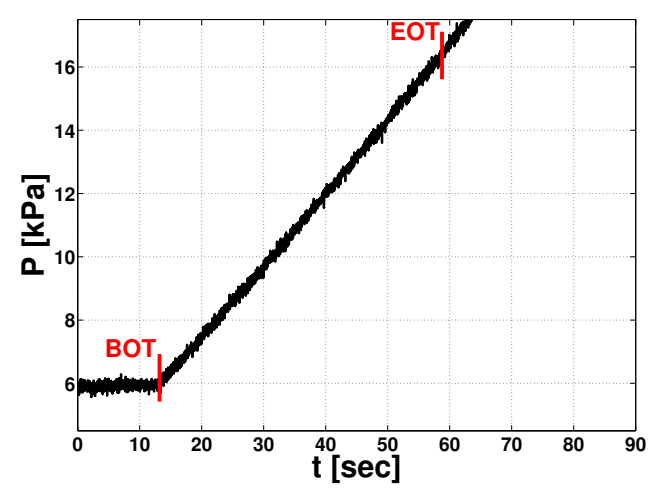

(d) $2^{\text {nd }}$ test at $68.95 \mathrm{kPa}$.

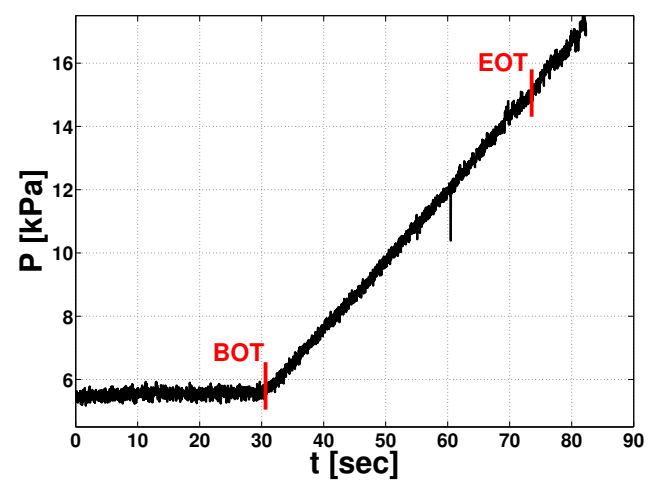

(f) $2^{\text {nd }}$ test at $96.53 \mathrm{kPa}$.

Figure F.11. Percolation pressure for VD422. The tests were conducted at three different compressions on the sample $41.37 \mathrm{kPa}, 68.95 \mathrm{kPa}, 96.53 \mathrm{kPa}$ while holding the flow rate constant at $18.75 \mathrm{E}-4 \mathrm{mLs}^{-1}$. 


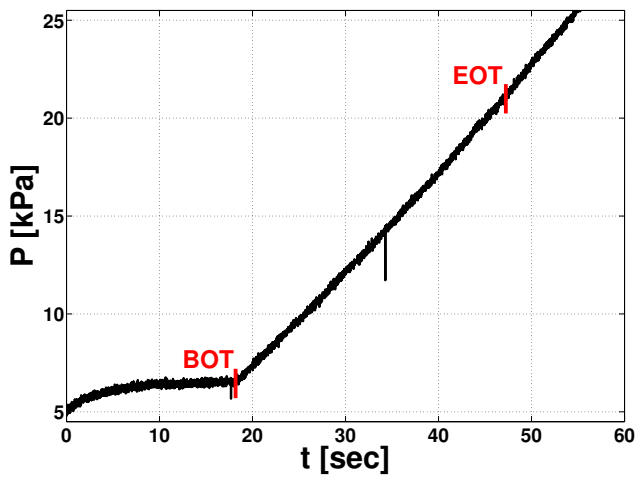

(a) $1^{\text {st }}$ test at $41.37 \mathrm{kPa}$.

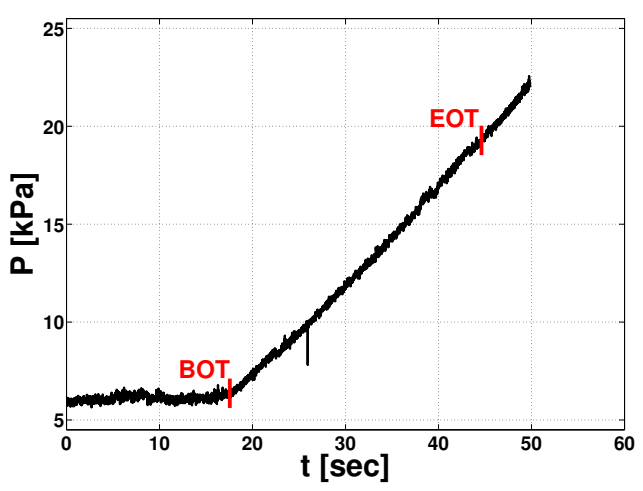

(c) $1^{\text {st }}$ test at $68.95 \mathrm{kPa}$.

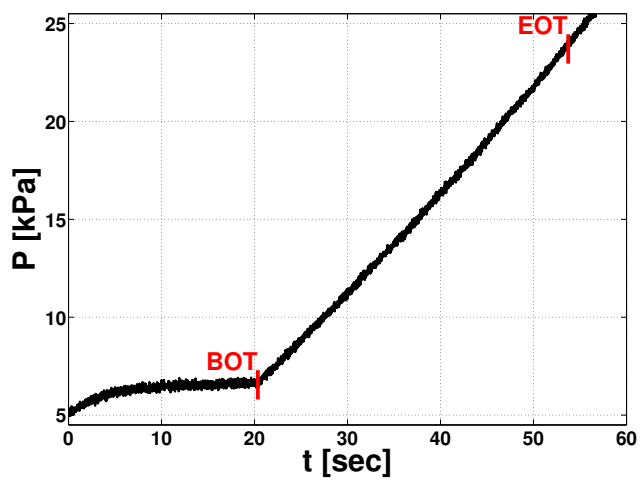

(e) $1^{\text {st }}$ test at $96.53 \mathrm{kPa}$.

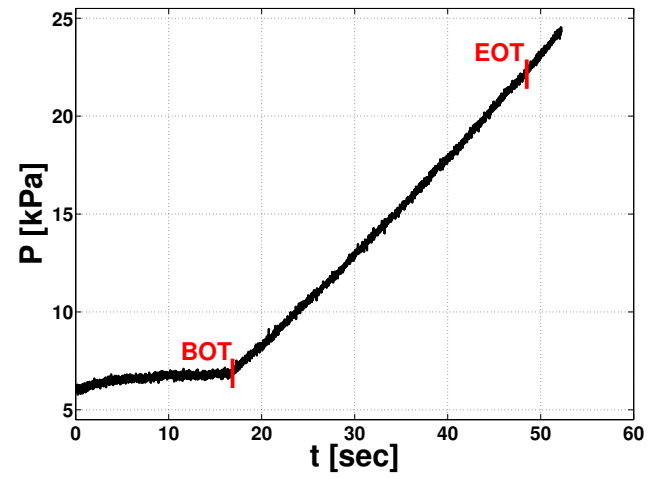

(b) $1^{\text {st }}$ test at $41.37 \mathrm{kPa}$.

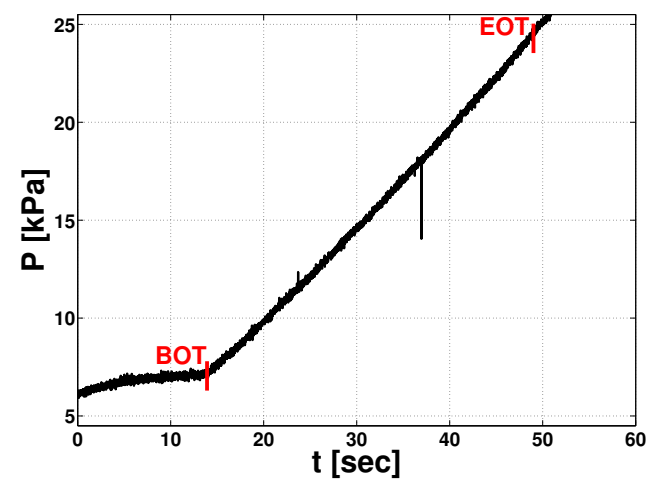

(d) $2^{\text {nd }}$ test at $68.95 \mathrm{kPa}$.

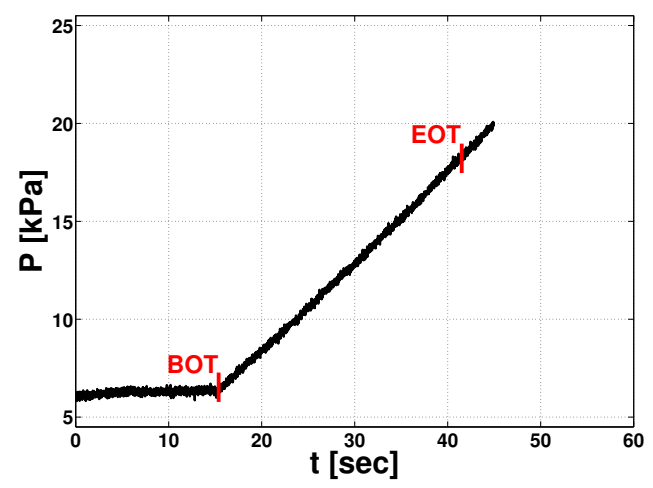

(f) $2^{\text {nd }}$ test at $96.53 \mathrm{kPa}$.

Figure F.12. Percolation pressure for VD422. The tests were conducted at three different compressions on the sample $41.37 \mathrm{kPa}, 68.95 \mathrm{kPa}, 96.53 \mathrm{kPa}$ while holding the flow rate constant at $37.08 \mathrm{E}-4 \mathrm{mLs}^{-1}$. 


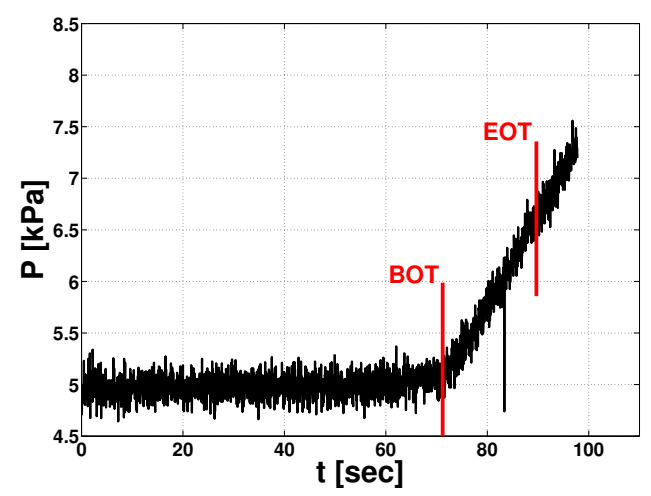

(a) $1^{\text {st }}$ test at $41.37 \mathrm{kPa}$.

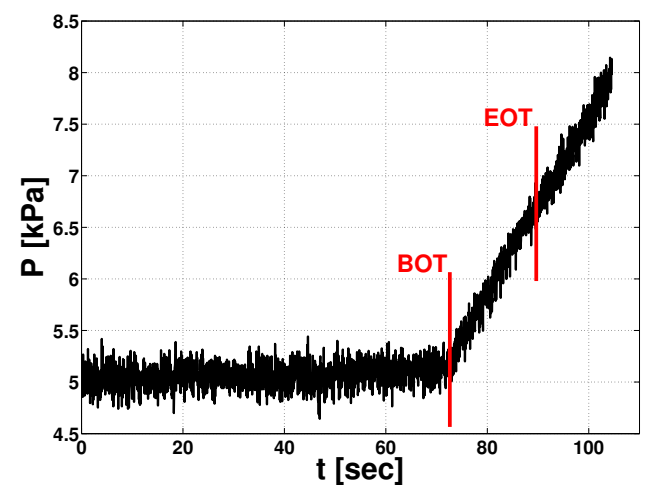

(c) $1^{\text {st }}$ test at $68.95 \mathrm{kPa}$.

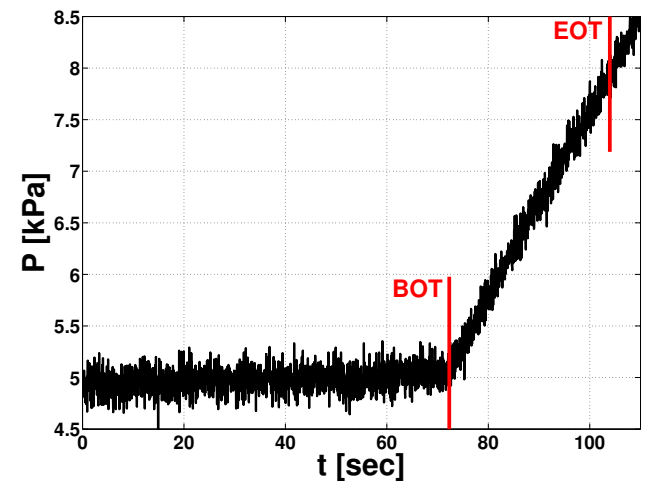

(e) $1^{\text {st }}$ test at $96.53 \mathrm{kPa}$.

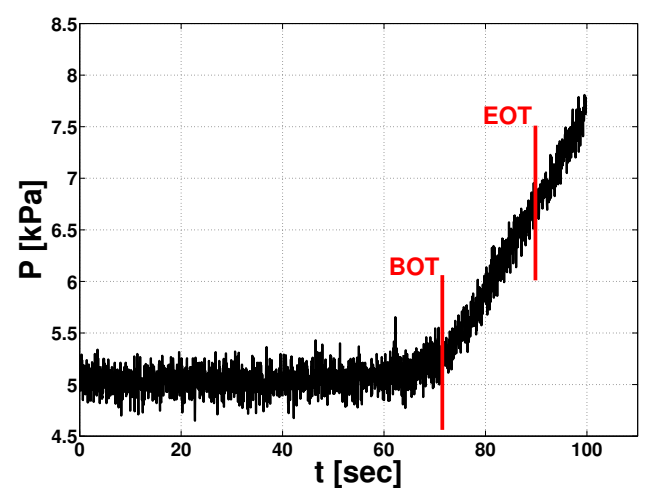

(b) $1^{\text {st }}$ test at $41.37 \mathrm{kPa}$.

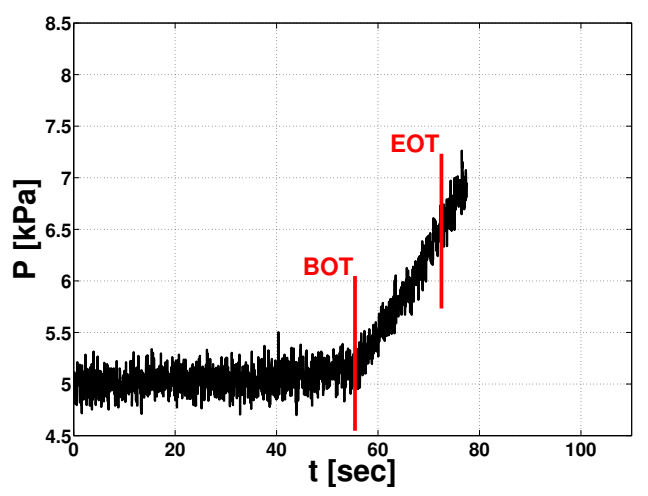

(d) $2^{\text {nd }}$ test at $68.95 \mathrm{kPa}$.

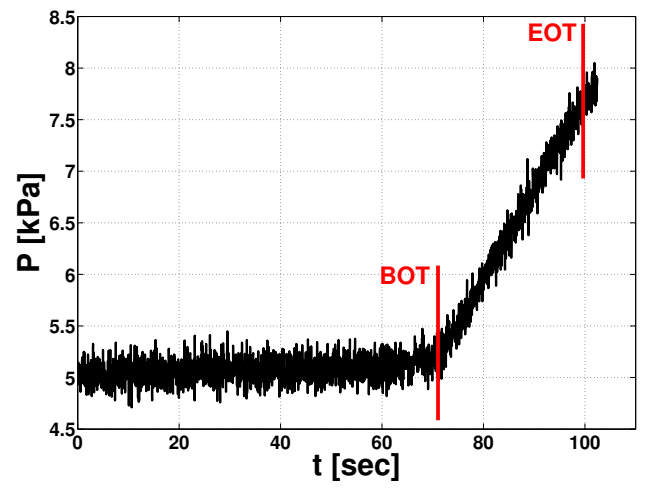

(f) $2^{\text {nd }}$ test at $96.53 \mathrm{kPa}$.

Figure F.13. Percolation pressure for VD424. The tests were conducted at three different compressions on the sample $41.37 \mathrm{kPa}, 68.95 \mathrm{kPa}, 96.53 \mathrm{kPa}$ while holding the flow rate constant at $9.48 \mathrm{E}-4 \mathrm{mLs}^{-1}$. 


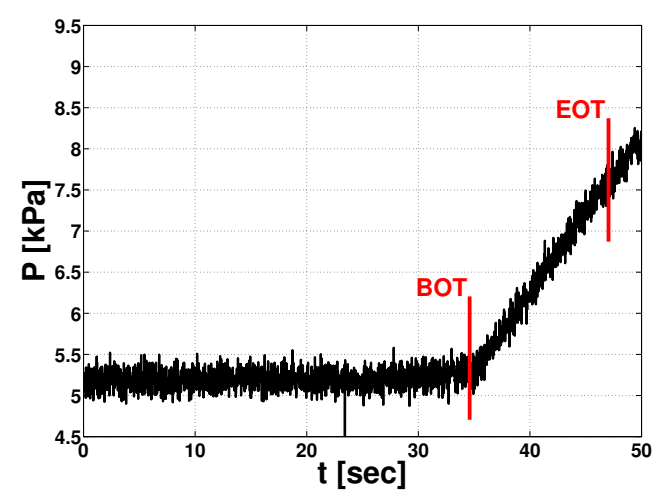

(a) $1^{\text {st }}$ test at $41.37 \mathrm{kPa}$.

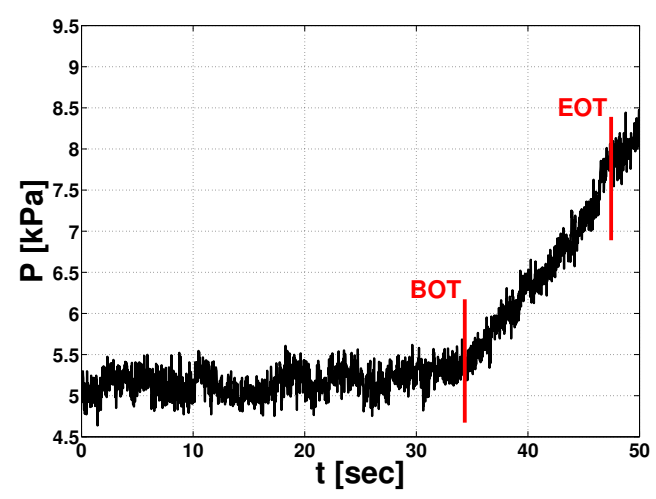

(c) $1^{\text {st }}$ test at $68.95 \mathrm{kPa}$.

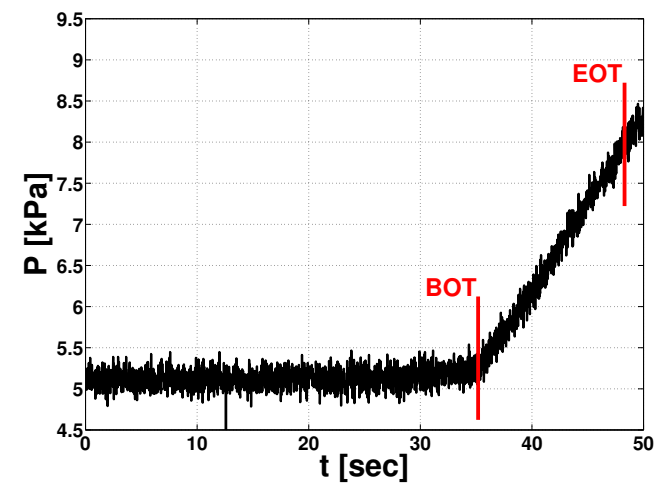

(e) $1^{\text {st }}$ test at $96.53 \mathrm{kPa}$.

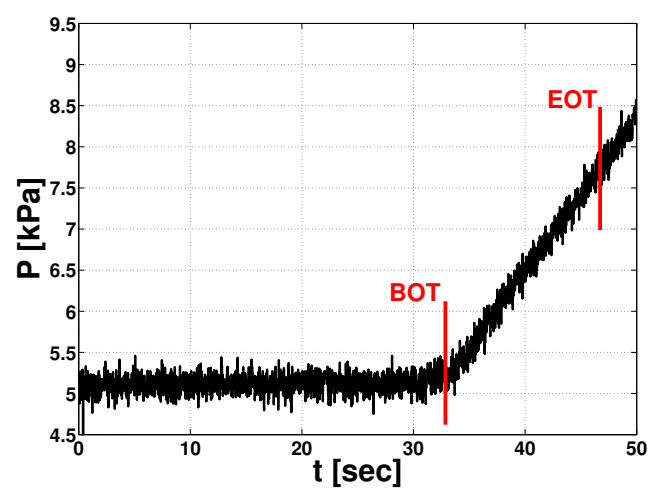

(b) $1^{\text {st }}$ test at $41.37 \mathrm{kPa}$.

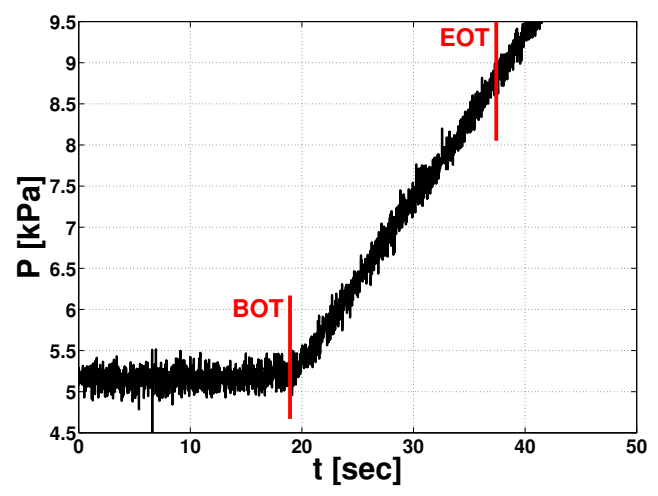

(d) $2^{\text {nd }}$ test at $68.95 \mathrm{kPa}$.

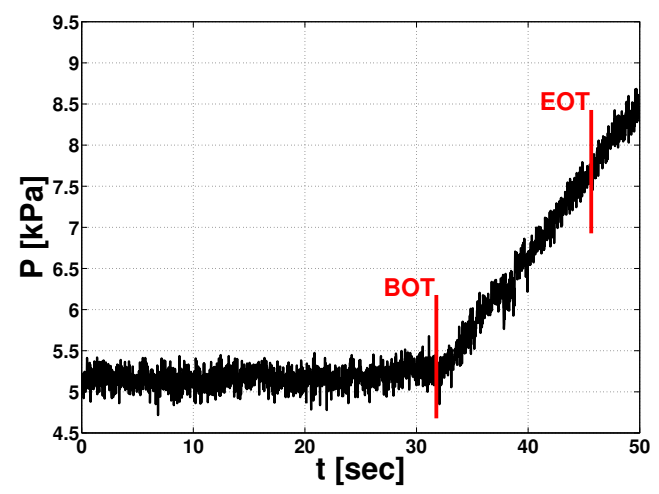

(f) $2^{\text {nd }}$ test at $96.53 \mathrm{kPa}$.

Figure F.14. Percolation pressure for VD424. The tests were conducted at three different compressions on the sample $41.37 \mathrm{kPa}, 68.95 \mathrm{kPa}, 96.53 \mathrm{kPa}$ while holding the flow rate constant at $18.75 \mathrm{E}-4 \mathrm{mLs}^{-1}$. 


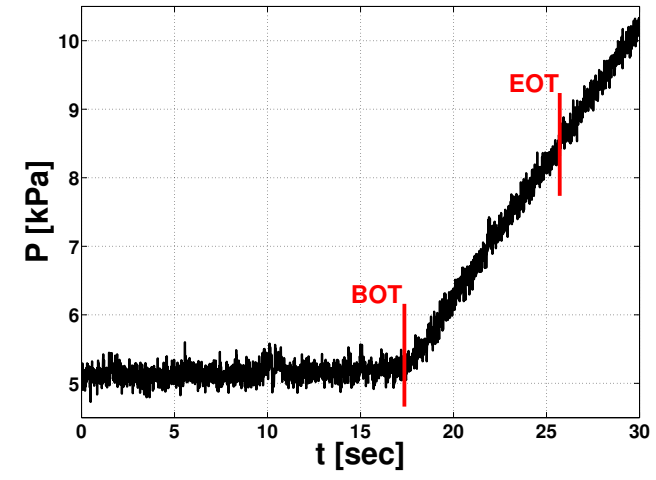

(a) $1^{\text {st }}$ test at $41.37 \mathrm{kPa}$.

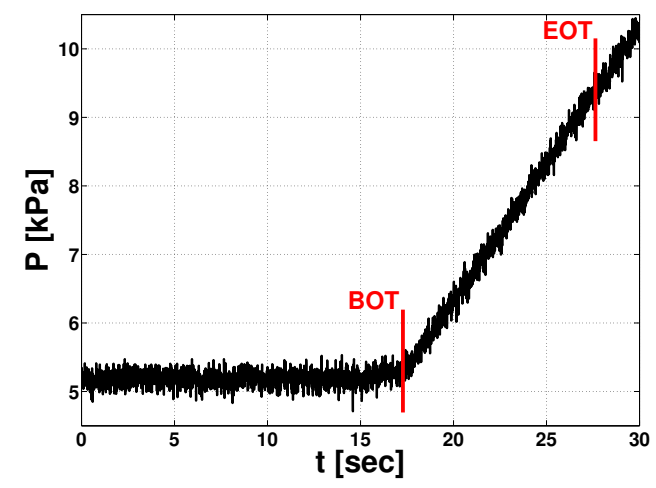

(c) $1^{\text {st }}$ test at $68.95 \mathrm{kPa}$.

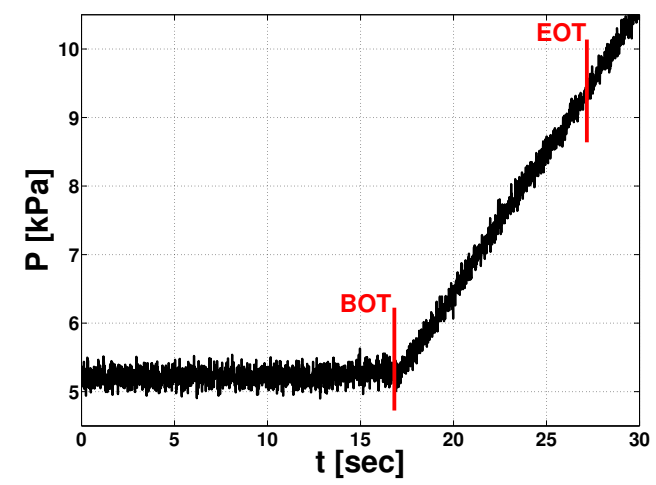

(e) $1^{\text {st }}$ test at $96.53 \mathrm{kPa}$.

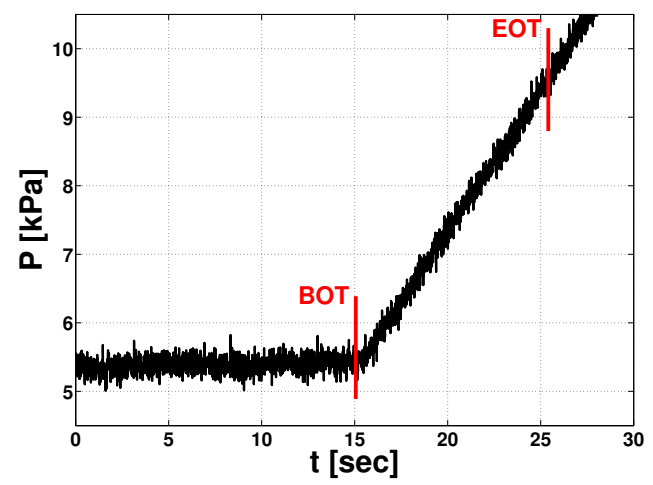

(b) $1^{\text {st }}$ test at $41.37 \mathrm{kPa}$.

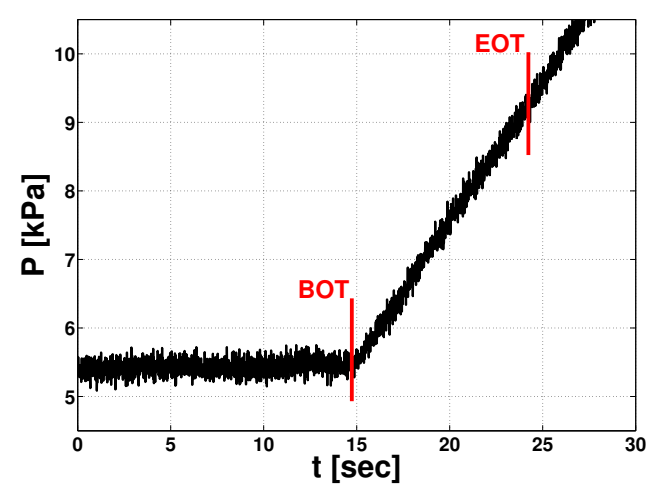

(d) $2^{\text {nd }}$ test at $68.95 \mathrm{kPa}$.

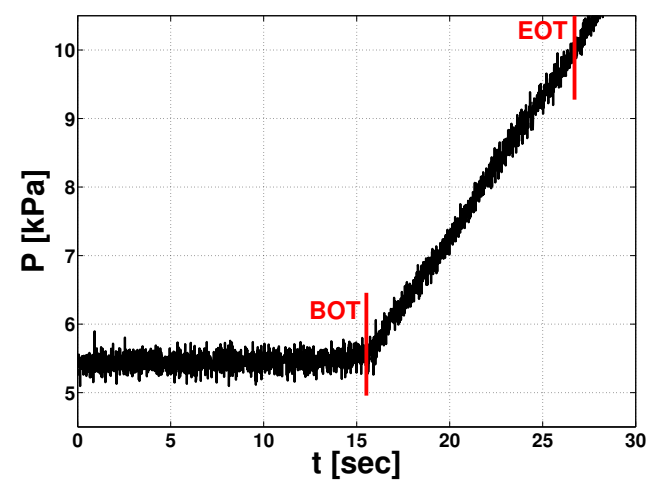

(f) $2^{\text {nd }}$ test at $96.53 \mathrm{kPa}$.

Figure F.15. Percolation pressure for VD424. The tests were conducted at three different compressions on the sample $41.37 \mathrm{kPa}, 68.95 \mathrm{kPa}, 96.53 \mathrm{kPa}$ while holding the flow rate constant at $37.08 \mathrm{E}-4 \mathrm{mLs}^{-1}$. 


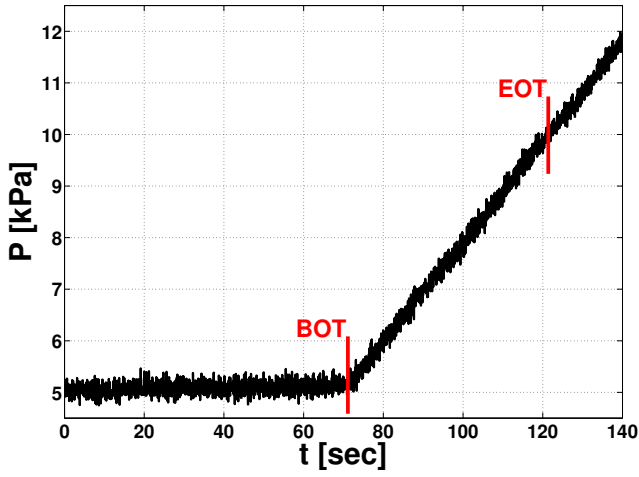

(a) $1^{\text {st }}$ test at $41.37 \mathrm{kPa}$.

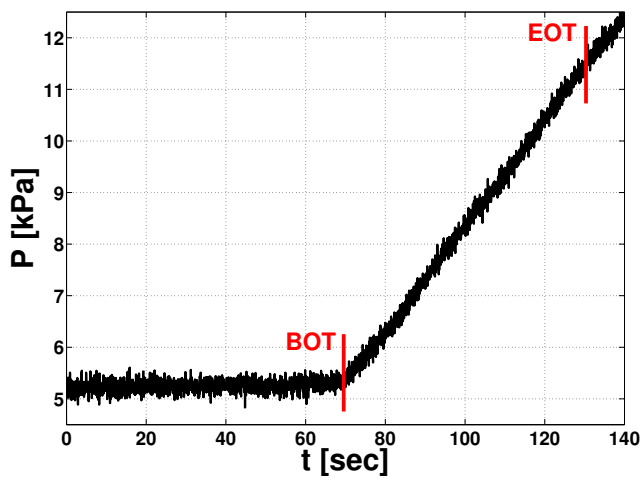

(c) $1^{\text {st }}$ test at $68.95 \mathrm{kPa}$.

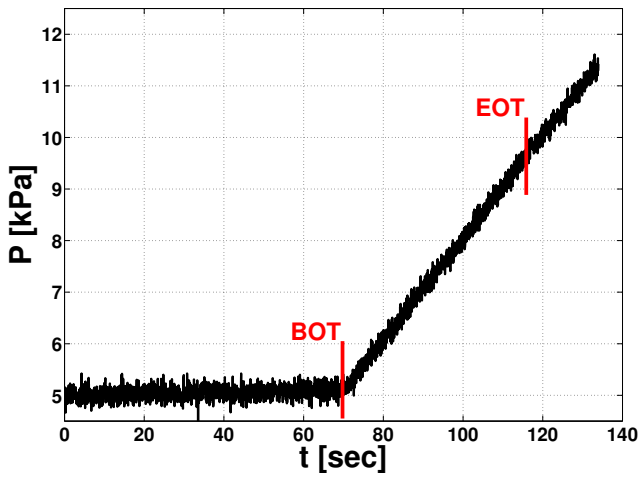

(e) $1^{\text {st }}$ test at $96.53 \mathrm{kPa}$.

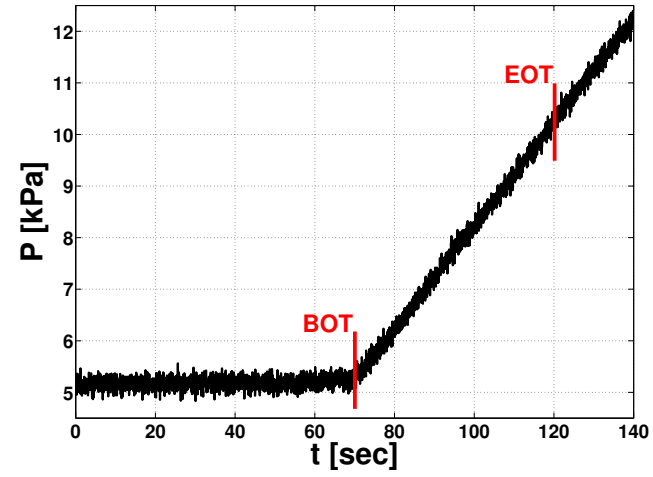

(b) $1^{\text {st }}$ test at $41.37 \mathrm{kPa}$.

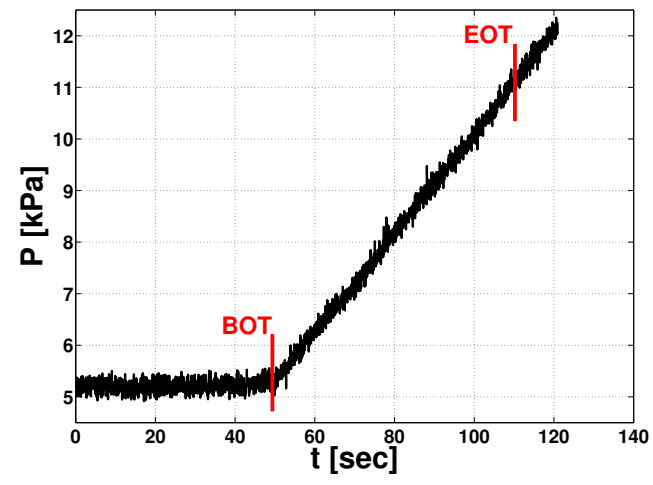

(d) $2^{\text {nd }}$ test at $68.95 \mathrm{kPa}$.

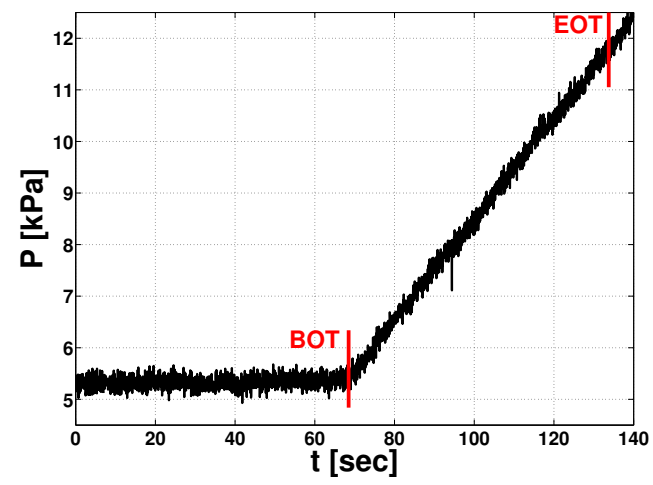

(f) $2^{\text {nd }}$ test at $96.53 \mathrm{kPa}$.

Figure F.16. Percolation pressure for VD425. The tests were conducted at three different compressions on the sample $41.37 \mathrm{kPa}, 68.95 \mathrm{kPa}, 96.53 \mathrm{kPa}$ while holding the flow rate constant at $9.48 \mathrm{E}-4 \mathrm{mLs}^{-1}$. 


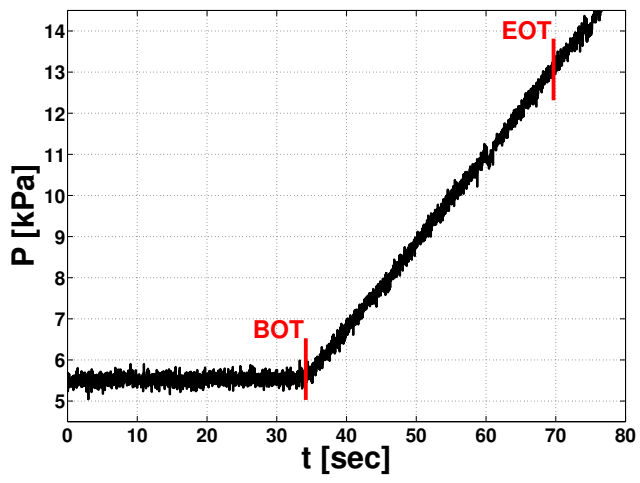

(a) $1^{\text {st }}$ test at $41.37 \mathrm{kPa}$.

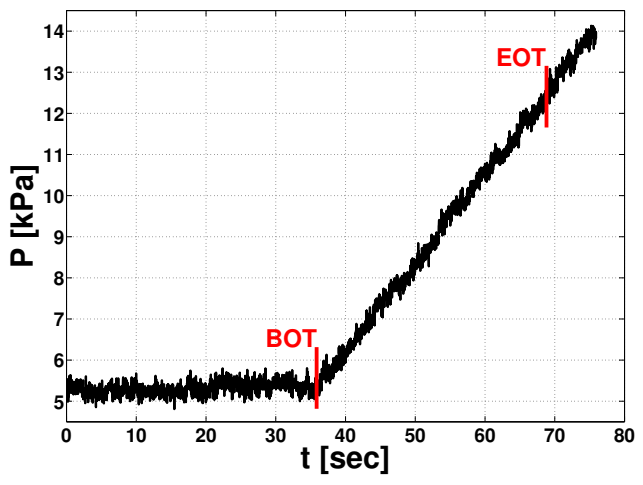

(c) $1^{\text {st }}$ test at $68.95 \mathrm{kPa}$.

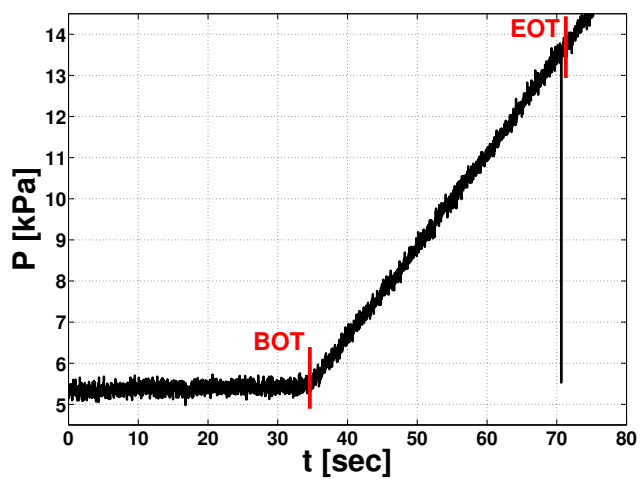

(e) $1^{\text {st }}$ test at $96.53 \mathrm{kPa}$.

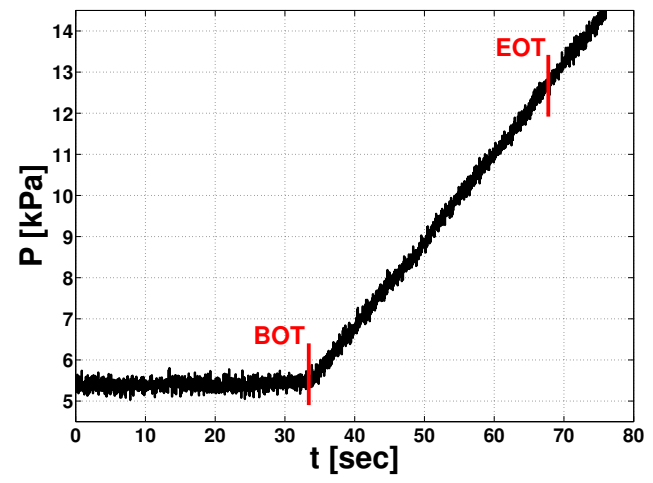

(b) $1^{\text {st }}$ test at $41.37 \mathrm{kPa}$.

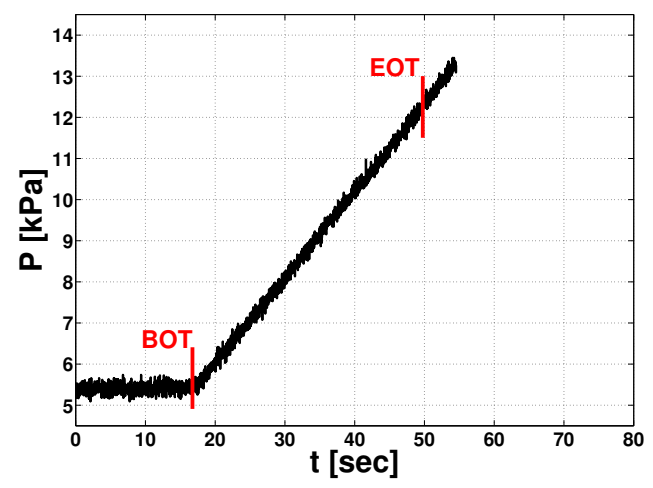

(d) $2^{\text {nd }}$ test at $68.95 \mathrm{kPa}$.

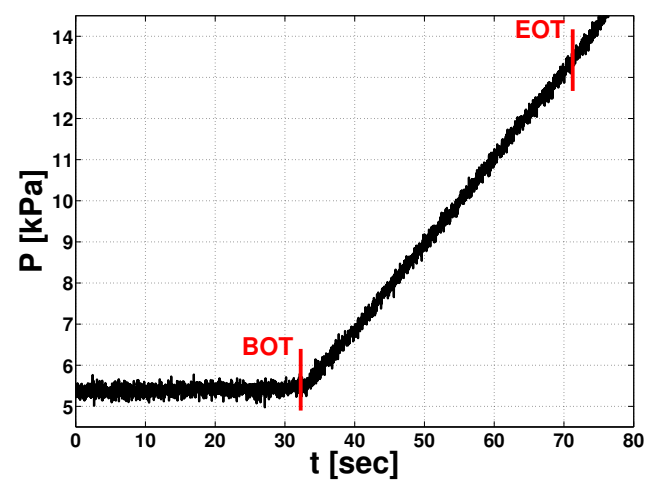

(f) $2^{\text {nd }}$ test at $96.53 \mathrm{kPa}$.

Figure F.17. Percolation pressure for VD425. The tests were conducted at three different compressions on the sample $41.37 \mathrm{kPa}, 68.95 \mathrm{kPa}, 96.53 \mathrm{kPa}$ while holding the flow rate constant at $18.75 \mathrm{E}-4 \mathrm{mLs}^{-1}$. 


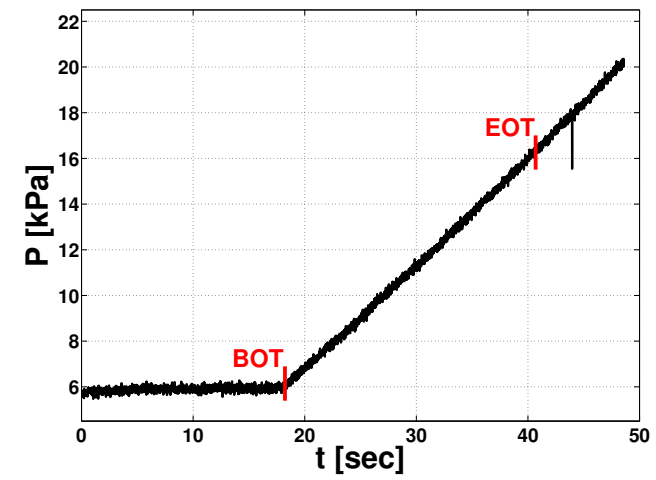

(a) $1^{\text {st }}$ test at $41.37 \mathrm{kPa}$.

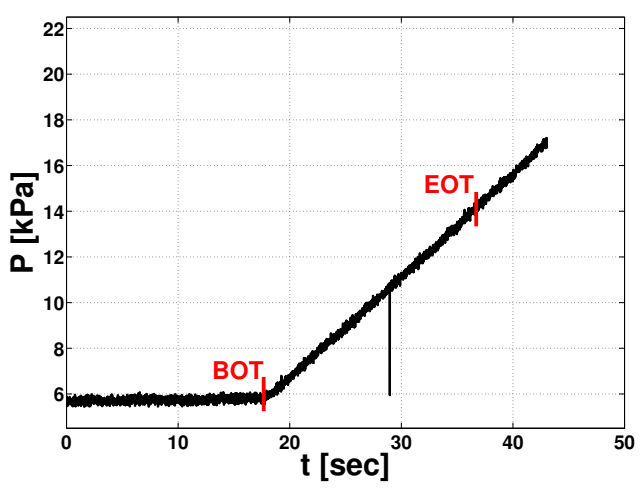

(c) $1^{\text {st }}$ test at $68.95 \mathrm{kPa}$.

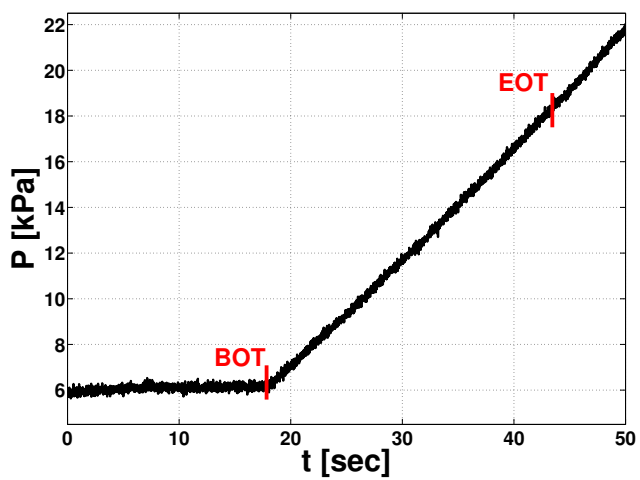

(e) $1^{\text {st }}$ test at $96.53 \mathrm{kPa}$.

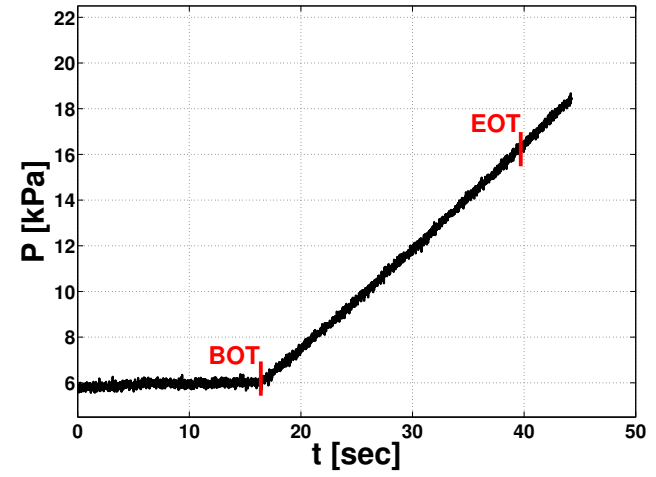

(b) $1^{\text {st }}$ test at $41.37 \mathrm{kPa}$.

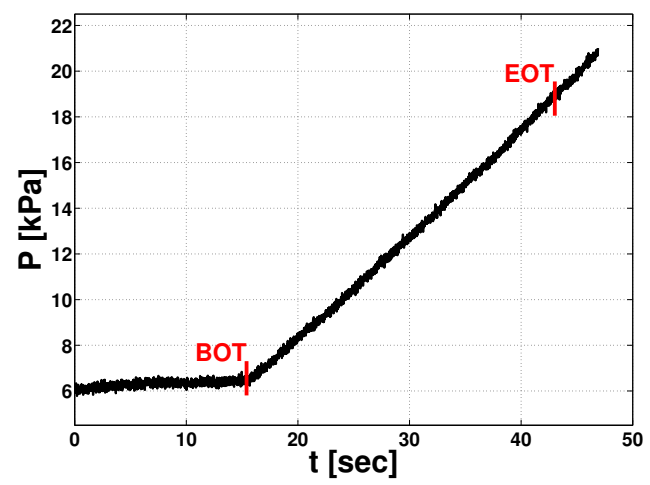

(d) $2^{\text {nd }}$ test at $68.95 \mathrm{kPa}$.

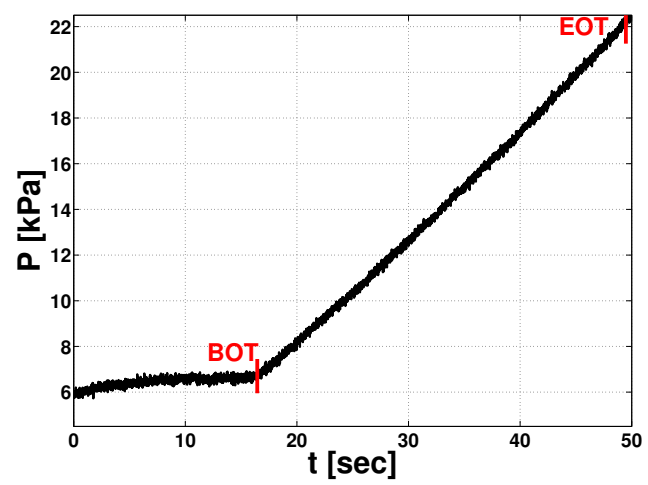

(f) $2^{\text {nd }}$ test at $96.53 \mathrm{kPa}$.

Figure F.18. Percolation pressure for full ccm sample VD425. The tests were conducted at three different compressions on the sample $41.37 \mathrm{kPa}$, $68.95 \mathrm{kPa}, 96.53 \mathrm{kPa}$ while holding the flow rate constant at $37.08 \mathrm{E}-$ $4 \mathrm{mLs}^{-1}$. 


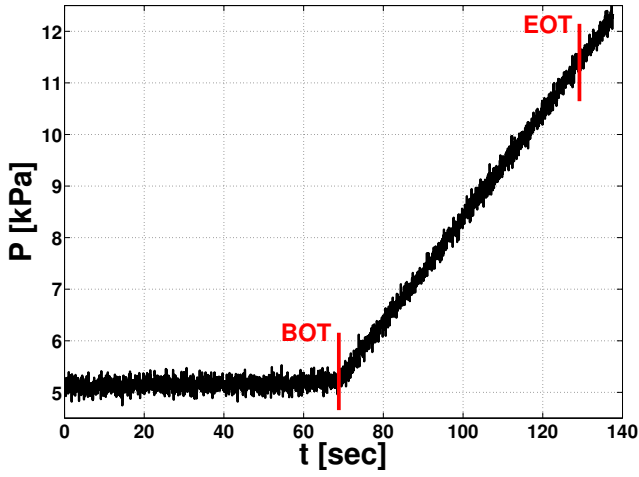

(a) $1^{\text {st }}$ test at $41.37 \mathrm{kPa}$.

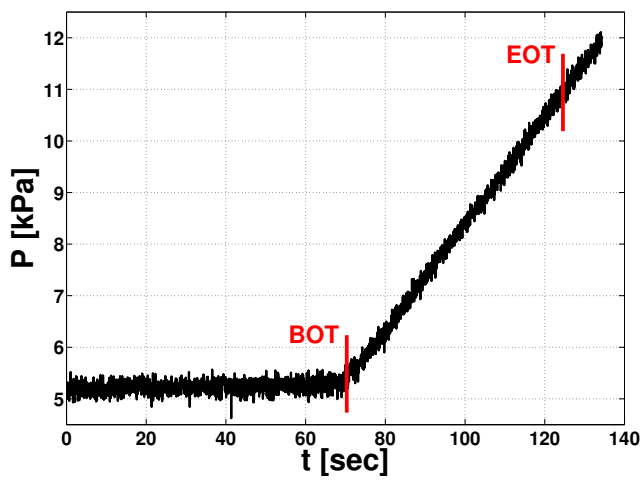

(c) $1^{\text {st }}$ test at $68.95 \mathrm{kPa}$.

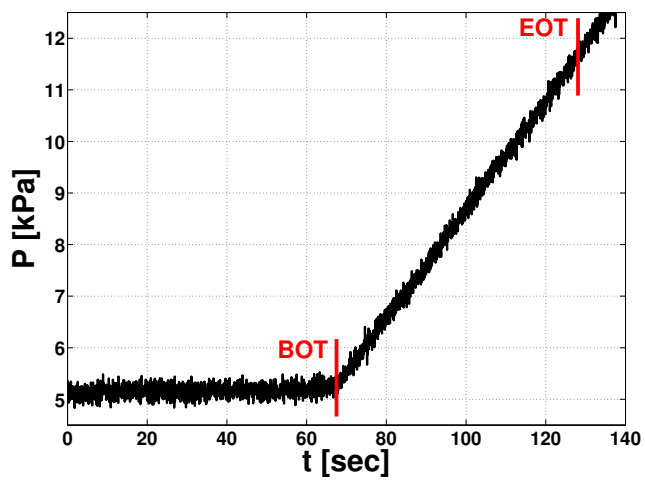

(e) $1^{\text {st }}$ test at $96.53 \mathrm{kPa}$.

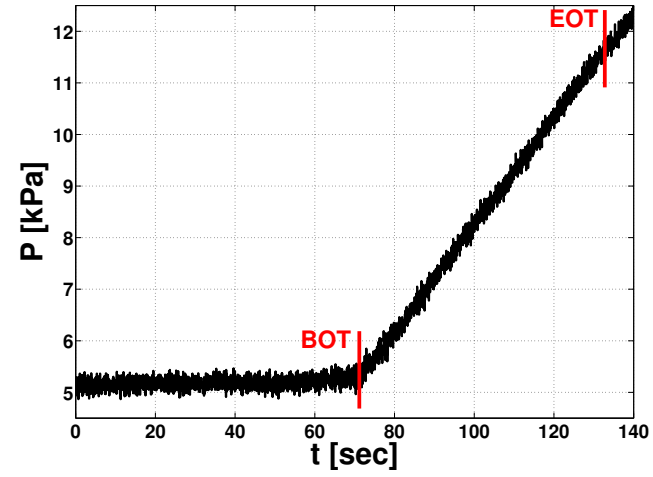

(b) $1^{\text {st }}$ test at $41.37 \mathrm{kPa}$.

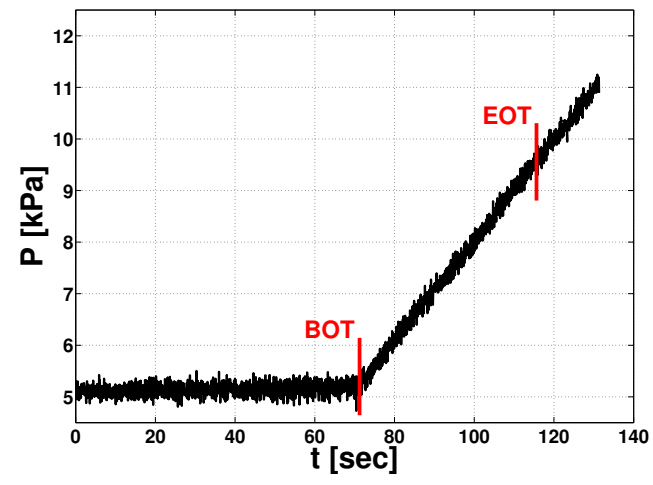

(d) $2^{\text {nd }}$ test at $68.95 \mathrm{kPa}$.

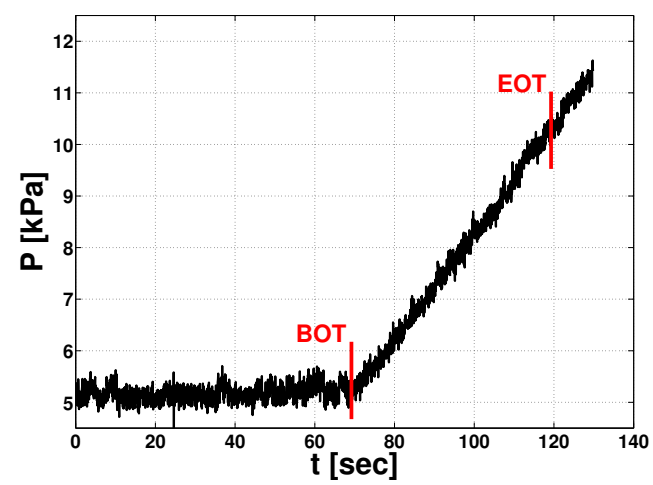

(f) $2^{\text {nd }}$ test at $96.53 \mathrm{kPa}$.

Figure F.19. Percolation pressure for VD432. The tests were conducted at three different compressions on the sample $41.37 \mathrm{kPa}, 68.95 \mathrm{kPa}, 96.53 \mathrm{kPa}$ while holding the flow rate constant at $9.48 \mathrm{E}-4 \mathrm{mLs}^{-1}$. 


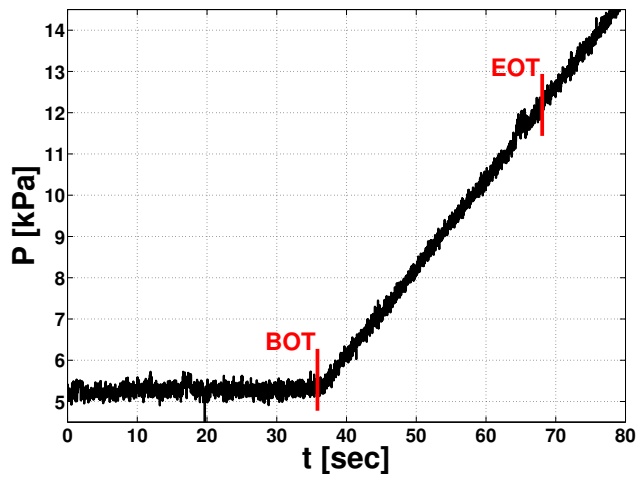

(a) $1^{\text {st }}$ test at $41.37 \mathrm{kPa}$.

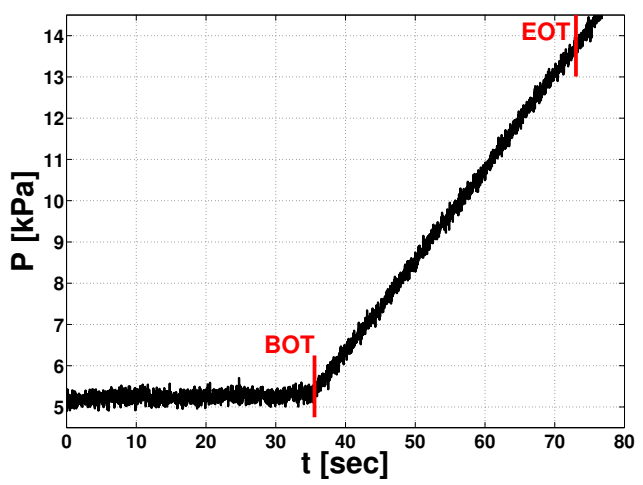

(c) $1^{\text {st }}$ test at $68.95 \mathrm{kPa}$.

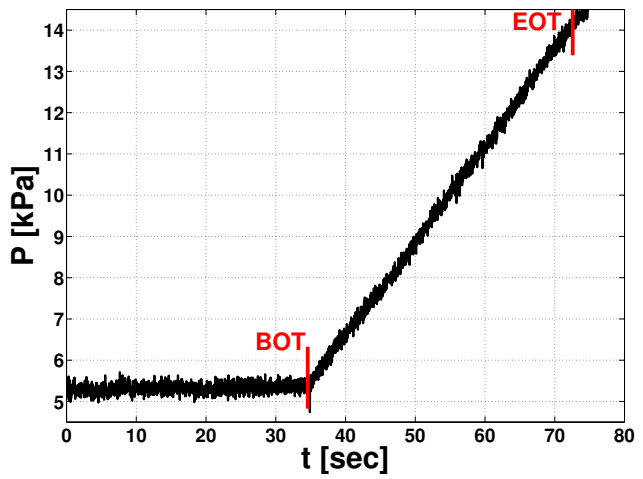

(e) $1^{\text {st }}$ test at $96.53 \mathrm{kPa}$.

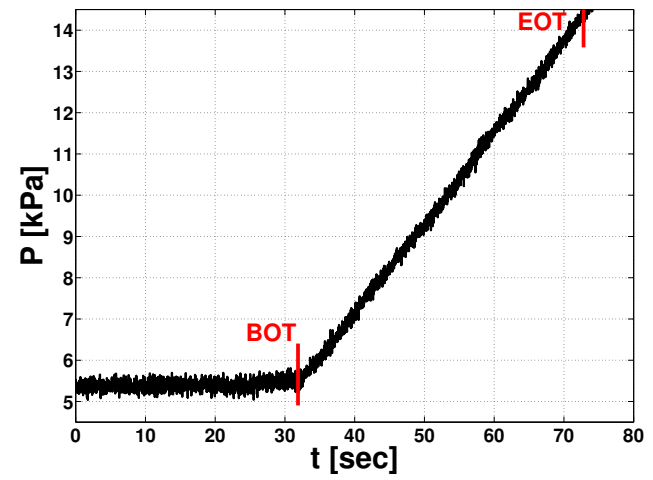

(b) $1^{\text {st }}$ test at $41.37 \mathrm{kPa}$.

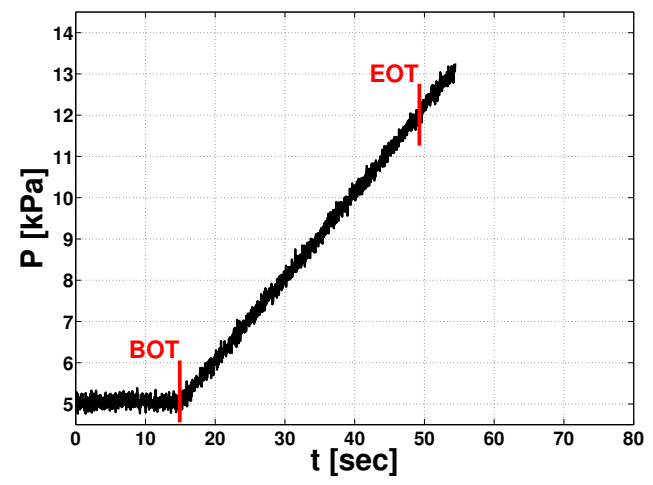

(d) $2^{\text {nd }}$ test at $68.95 \mathrm{kPa}$.

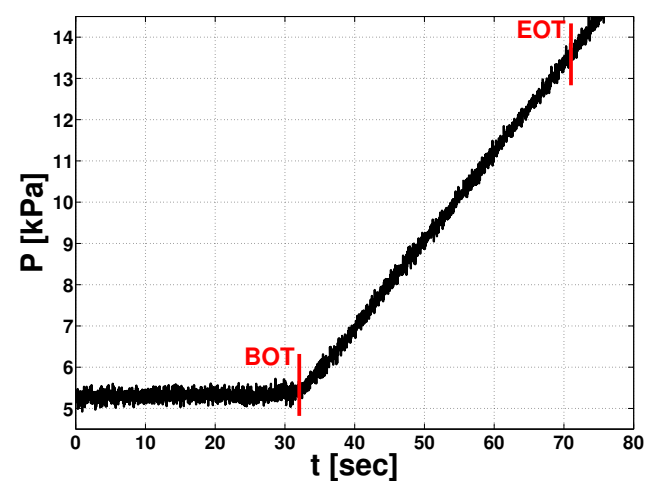

(f) $2^{\text {nd }}$ test at $96.53 \mathrm{kPa}$.

Figure F.20. Percolation pressure for VD432. The tests were conducted at three different compressions on the sample $41.37 \mathrm{kPa}, 68.95 \mathrm{kPa}, 96.53 \mathrm{kPa}$ while holding the flow rate constant at $18.75 \mathrm{E}-4 \mathrm{mLs}^{-1}$. 


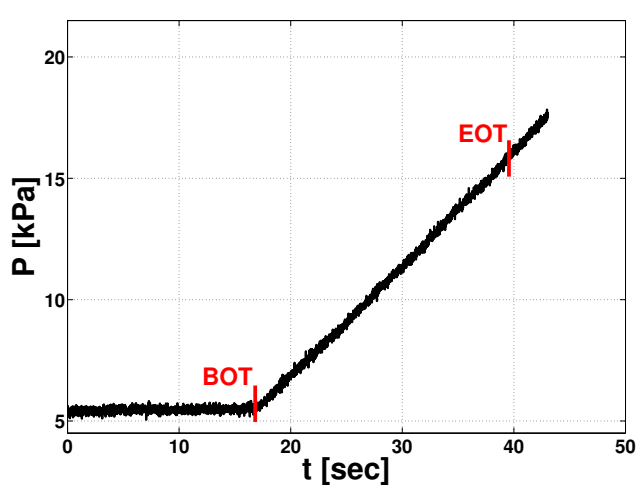

(a) $1^{\text {st }}$ test at $41.37 \mathrm{kPa}$.

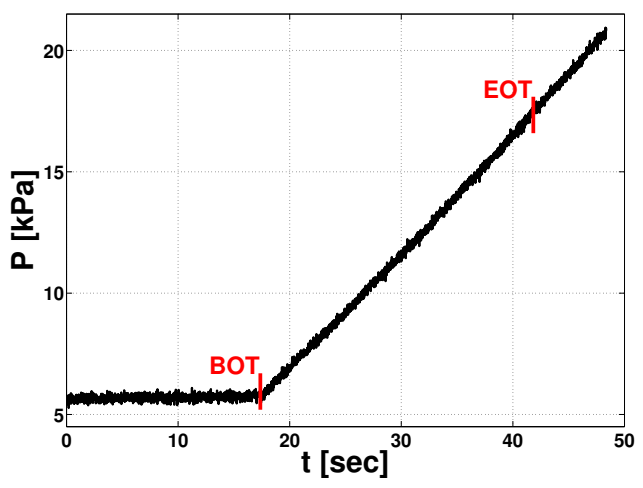

(c) $1^{\text {st }}$ test at $68.95 \mathrm{kPa}$.

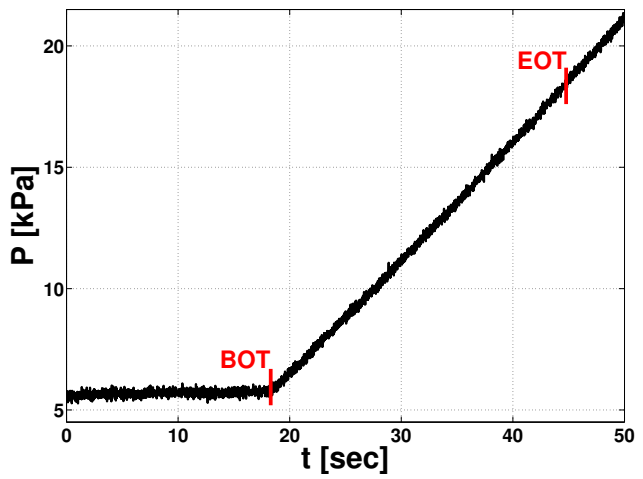

(e) $1^{\text {st }}$ test at $96.53 \mathrm{kPa}$.

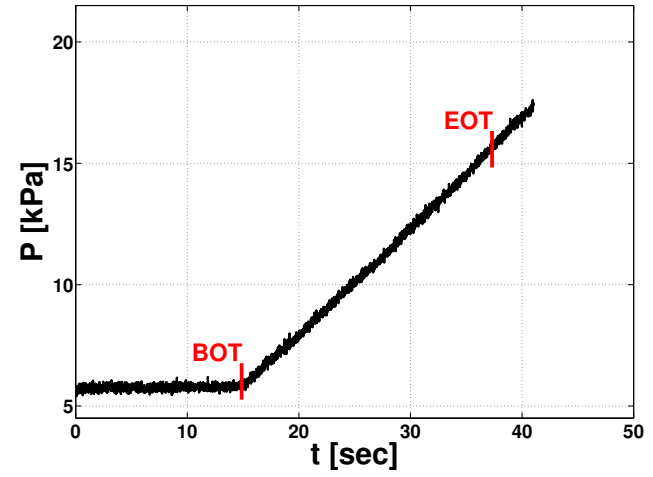

(b) $1^{\text {st }}$ test at $41.37 \mathrm{kPa}$.

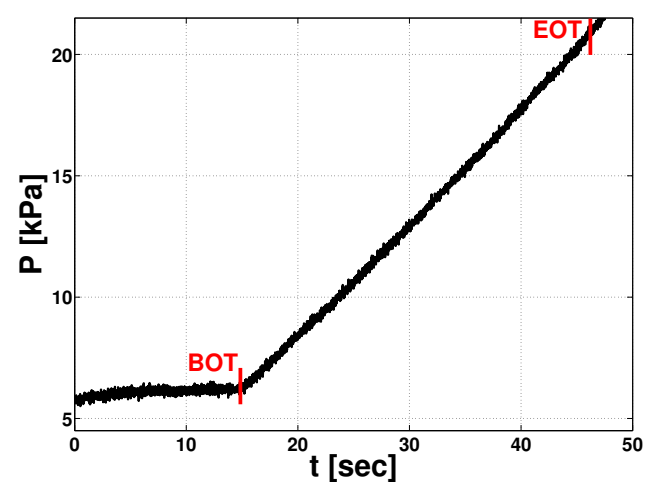

(d) $2^{\text {nd }}$ test at $68.95 \mathrm{kPa}$.

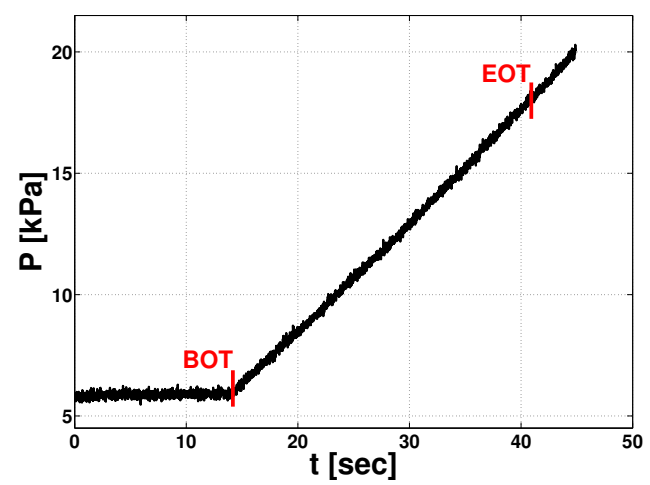

(f) $2^{\text {nd }}$ test at $96.53 \mathrm{kPa}$.

Figure F.21. Percolation pressure for VD432. The tests were conducted at three different compressions on the sample $41.37 \mathrm{kPa}, 68.95 \mathrm{kPa}, 96.53 \mathrm{kPa}$ while holding the flow rate constant at $37.08 \mathrm{E}-4 \mathrm{mLs}^{-1}$. 


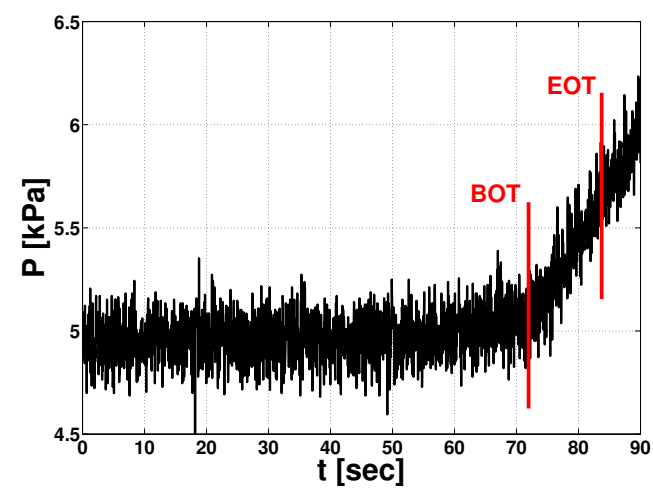

(a) $1^{\text {st }}$ test at $41.37 \mathrm{kPa}$.

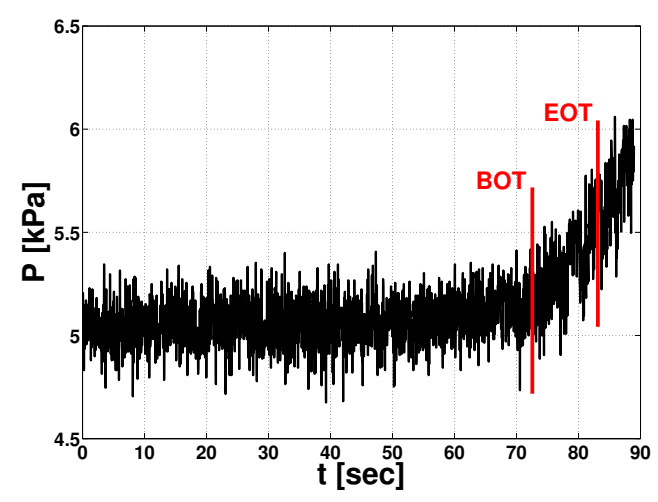

(c) $1^{\text {st }}$ test at $68.95 \mathrm{kPa}$.

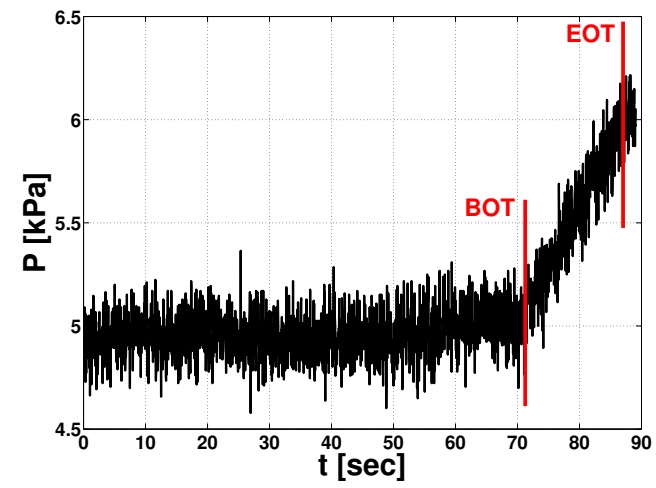

(e) $1^{\text {st }}$ test at $96.53 \mathrm{kPa}$.

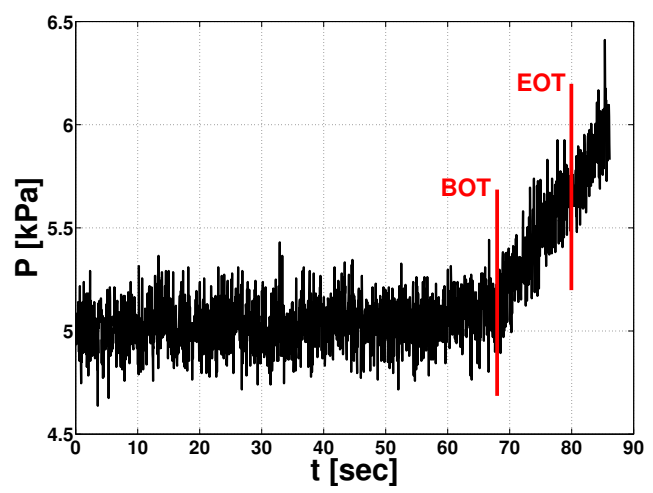

(b) $1^{\text {st }}$ test at $41.37 \mathrm{kPa}$.

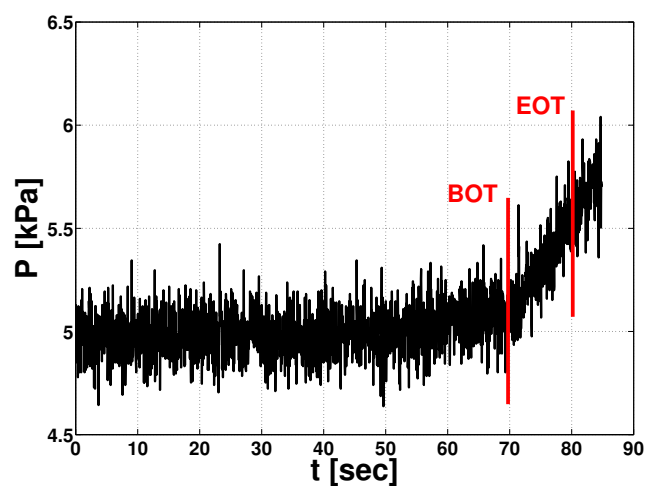

(d) $2^{\text {nd }}$ test at $68.95 \mathrm{kPa}$.

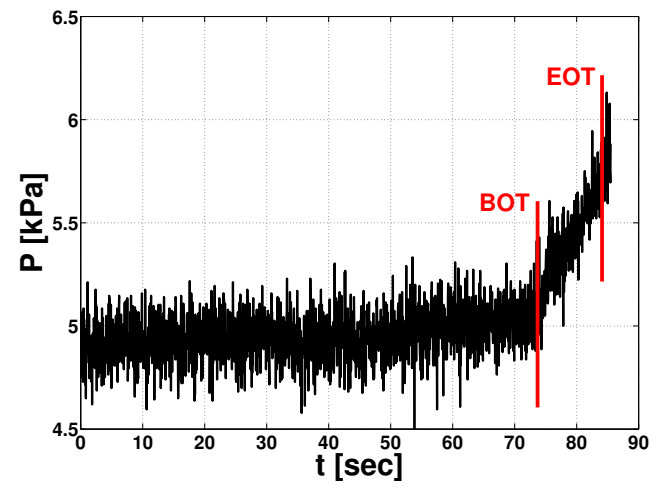

(f) $2^{\text {nd }}$ test at $96.53 \mathrm{kPa}$.

Figure F.22. Percolation pressure for VD436. The tests were conducted at three different compressions on the sample $41.37 \mathrm{kPa}, 68.95 \mathrm{kPa}, 96.53 \mathrm{kPa}$ while holding the flow rate constant at $9.48 \mathrm{E}-4 \mathrm{mLs}^{-1}$. 


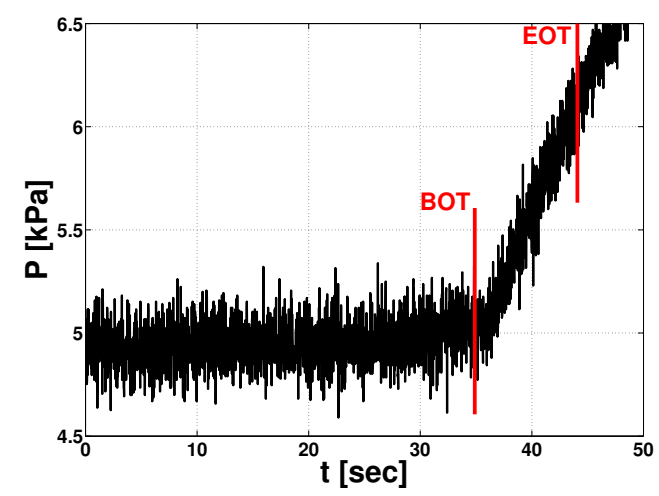

(a) $1^{\text {st }}$ test at $41.37 \mathrm{kPa}$.

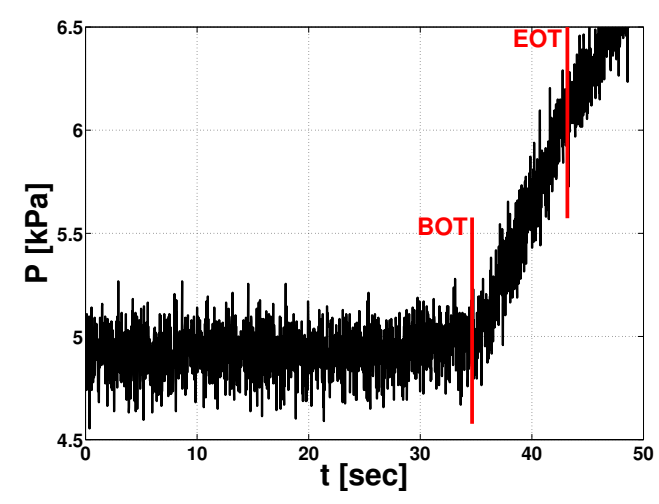

(c) $1^{\text {st }}$ test at $68.95 \mathrm{kPa}$.

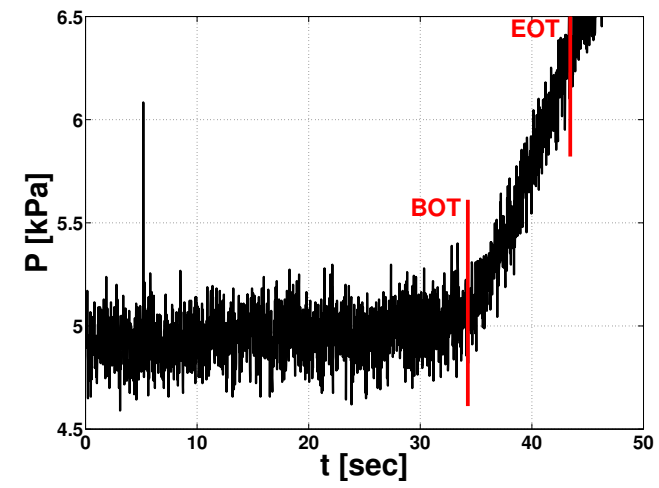

(e) $1^{\text {st }}$ test at $96.53 \mathrm{kPa}$.

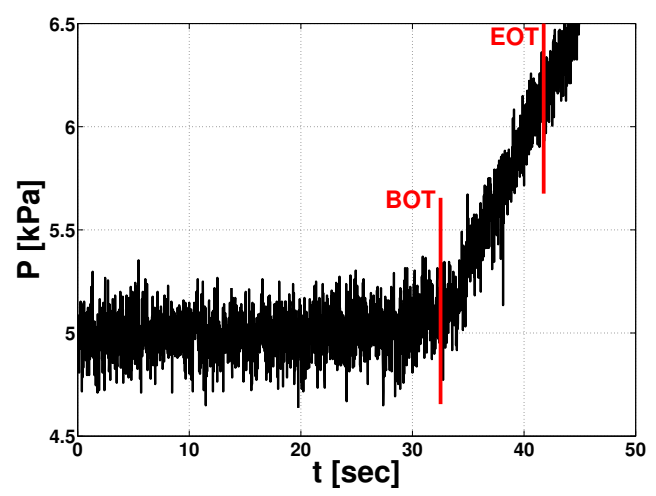

(b) $1^{\text {st }}$ test at $41.37 \mathrm{kPa}$.

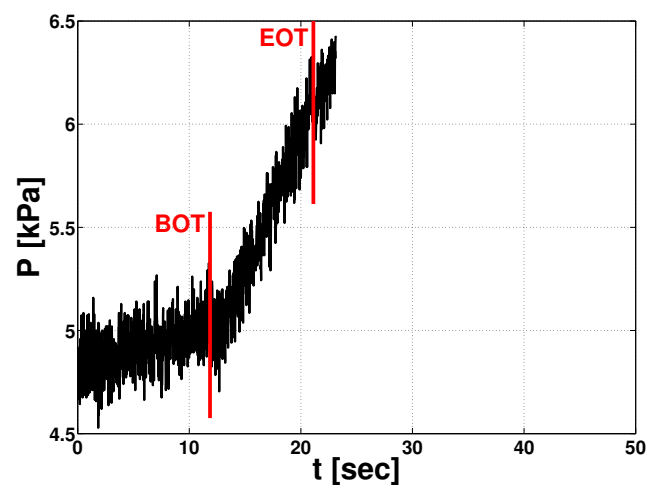

(d) $2^{\text {nd }}$ test at $68.95 \mathrm{kPa}$.

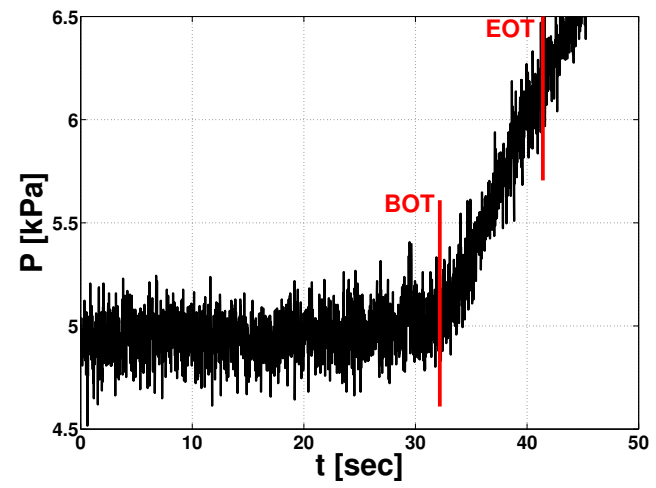

(f) $2^{\text {nd }}$ test at $96.53 \mathrm{kPa}$.

Figure F.23. Percolation pressure for VD436. The tests were conducted at three different compressions on the sample $41.37 \mathrm{kPa}, 68.95 \mathrm{kPa}, 96.53 \mathrm{kPa}$ while holding the flow rate constant at $18.75 \mathrm{E}-4 \mathrm{mLs}^{-1}$. 


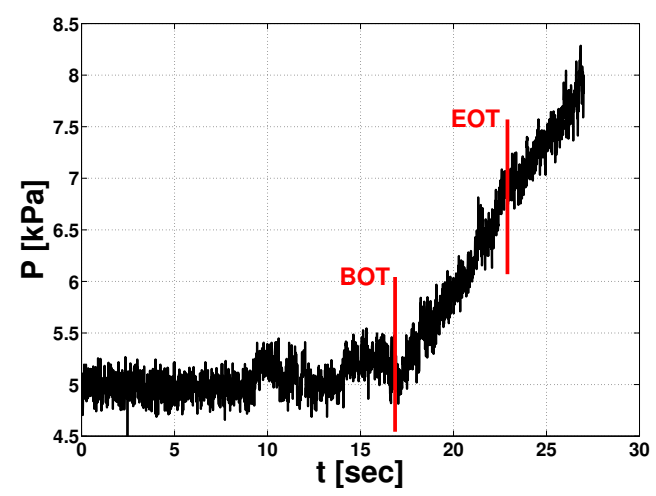

(a) $1^{\text {st }}$ test at $41.37 \mathrm{kPa}$.

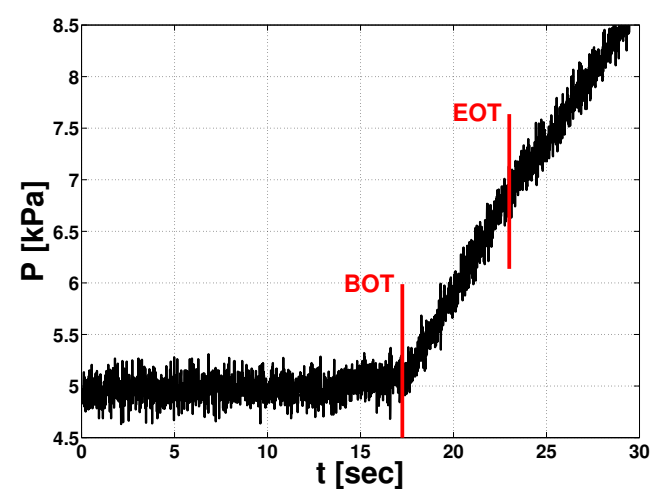

(c) $1^{\text {st }}$ test at $68.95 \mathrm{kPa}$.

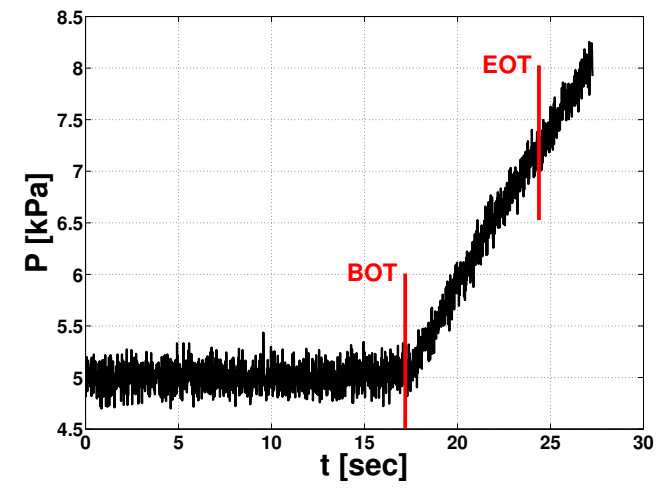

(e) $1^{\text {st }}$ test at $96.53 \mathrm{kPa}$.

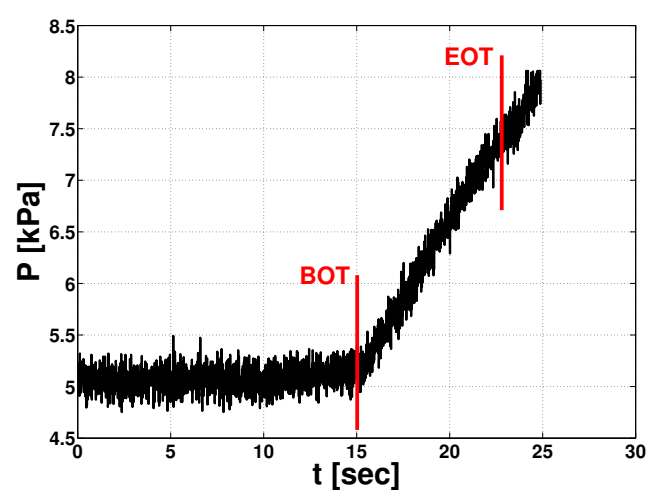

(b) $1^{\text {st }}$ test at $41.37 \mathrm{kPa}$.

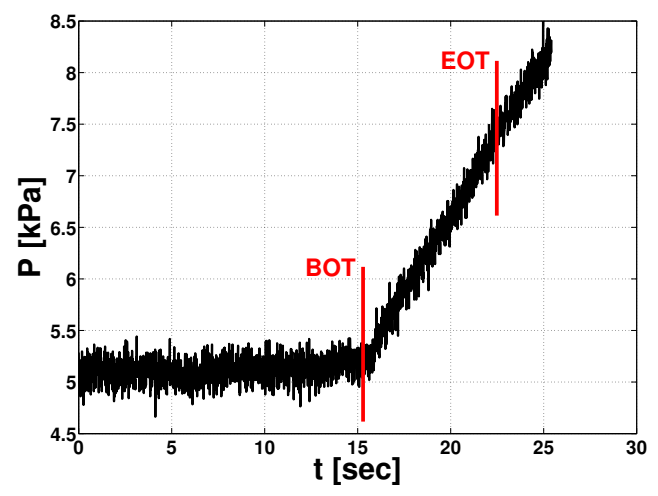

(d) $2^{\text {nd }}$ test at $68.95 \mathrm{kPa}$.

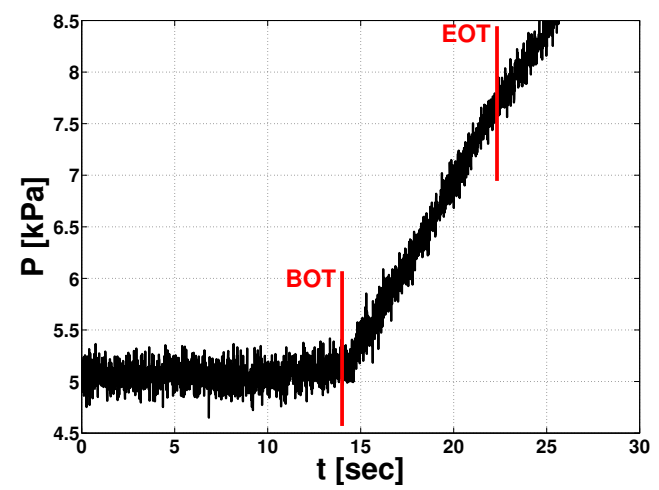

(f) $2^{\text {nd }}$ test at $96.53 \mathrm{kPa}$.

Figure F.24. Percolation pressure for VD436. The tests were conducted at three different compressions on the sample $41.37 \mathrm{kPa}, 68.95 \mathrm{kPa}, 96.53 \mathrm{kPa}$ while holding the flow rate constant at $37.08 \mathrm{E}-4 \mathrm{mLs}^{-1}$. 


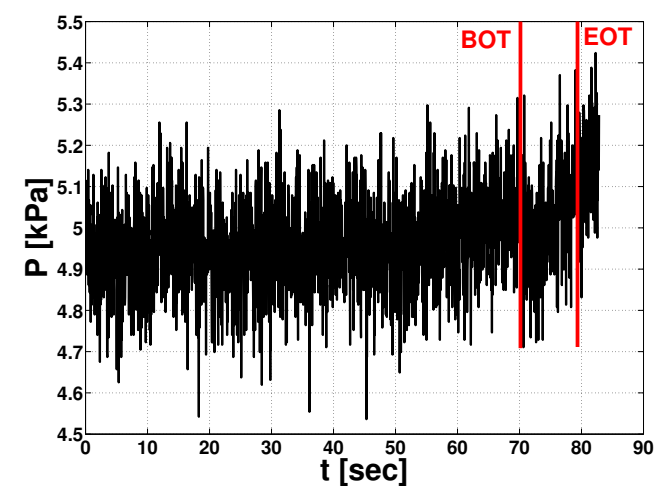

(a) $1^{\text {st }}$ test at $41.37 \mathrm{kPa}$.

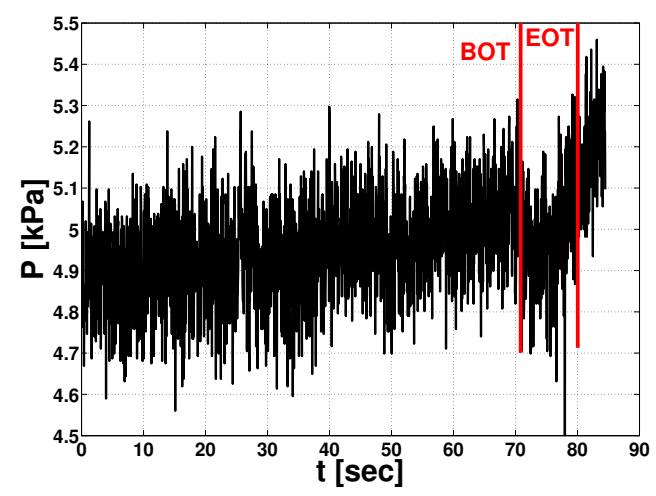

(c) $1^{\text {st }}$ test at $68.95 \mathrm{kPa}$.

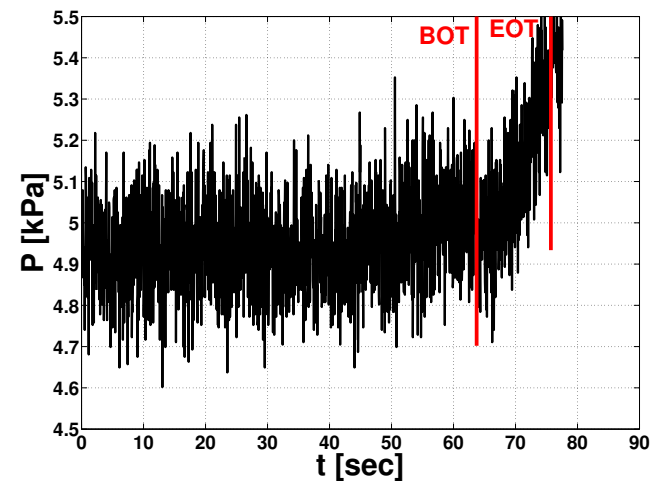

(e) $1^{\text {st }}$ test at $96.53 \mathrm{kPa}$.

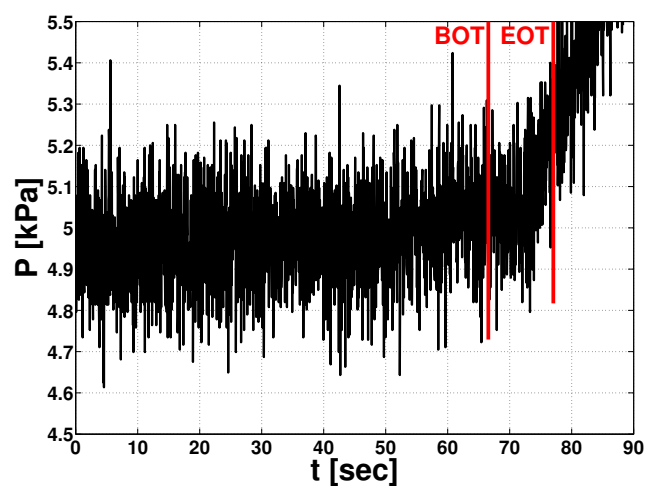

(b) $1^{\text {st }}$ test at $41.37 \mathrm{kPa}$.

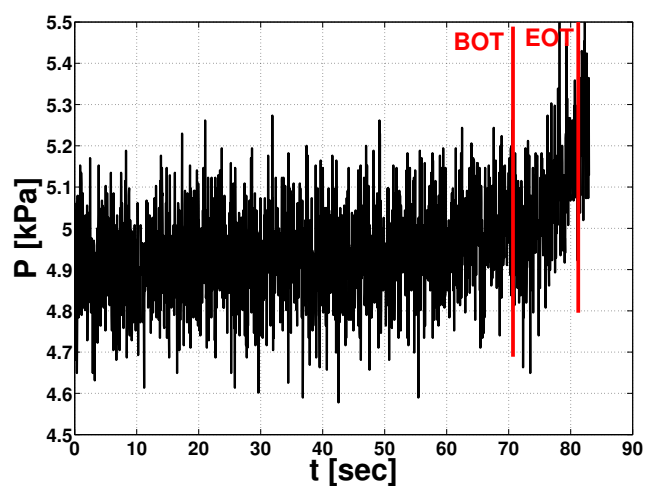

(d) $2^{\text {nd }}$ test at $68.95 \mathrm{kPa}$.

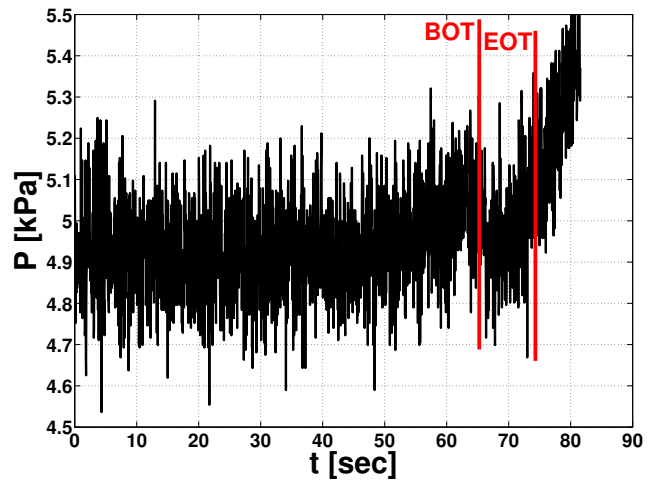

(f) $2^{\text {nd }}$ test at $96.53 \mathrm{kPa}$.

Figure F.25. Percolation pressure for VD328. The tests were conducted at three different compressions on the sample $41.37 \mathrm{kPa}, 68.95 \mathrm{kPa}, 96.53 \mathrm{kPa}$ while holding the flow rate constant at $9.48 \mathrm{E}-4 \mathrm{mLs}^{-1}$. 


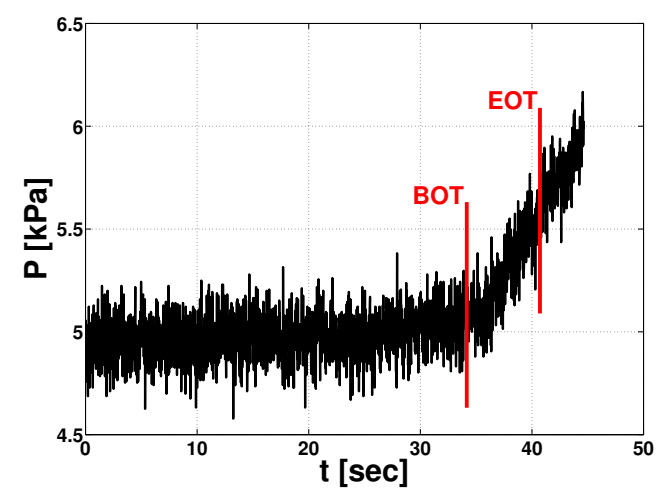

(a) $1^{\text {st }}$ test at $41.37 \mathrm{kPa}$.

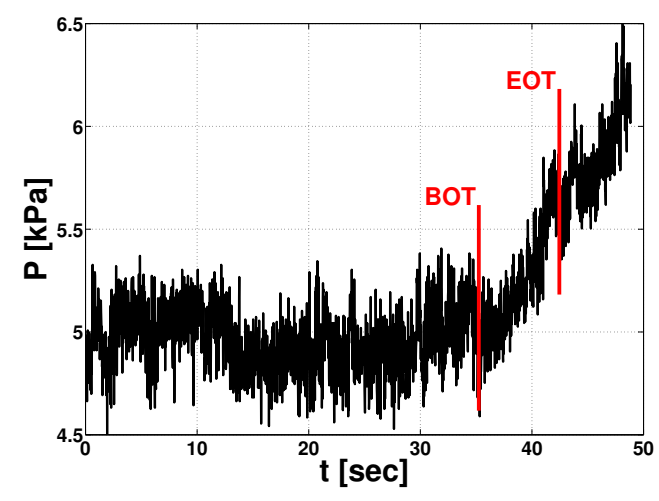

(c) $1^{\text {st }}$ test at $68.95 \mathrm{kPa}$.

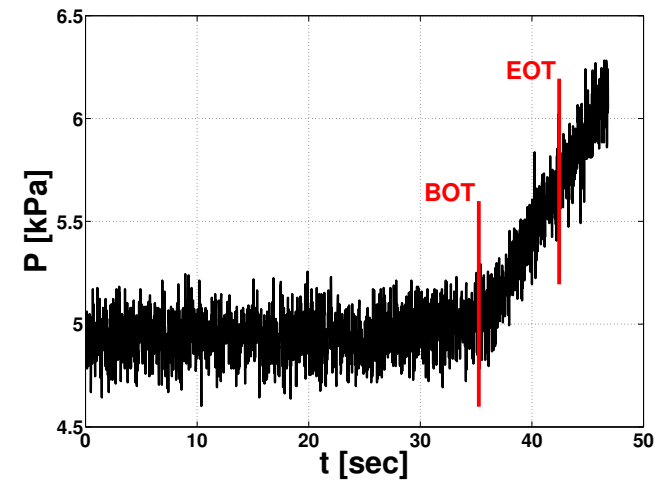

(e) $1^{\text {st }}$ test at $96.53 \mathrm{kPa}$.

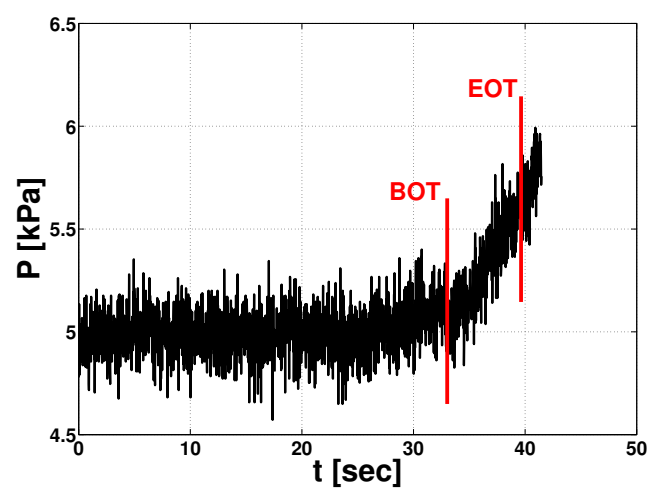

(b) $1^{\text {st }}$ test at $41.37 \mathrm{kPa}$.

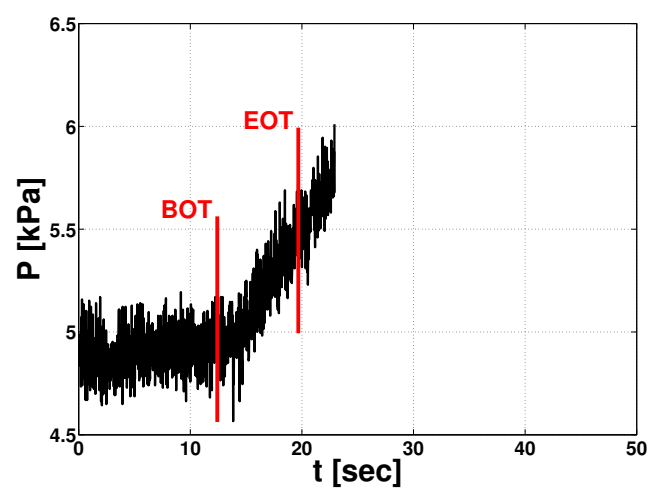

(d) $2^{\text {nd }}$ test at $68.95 \mathrm{kPa}$.

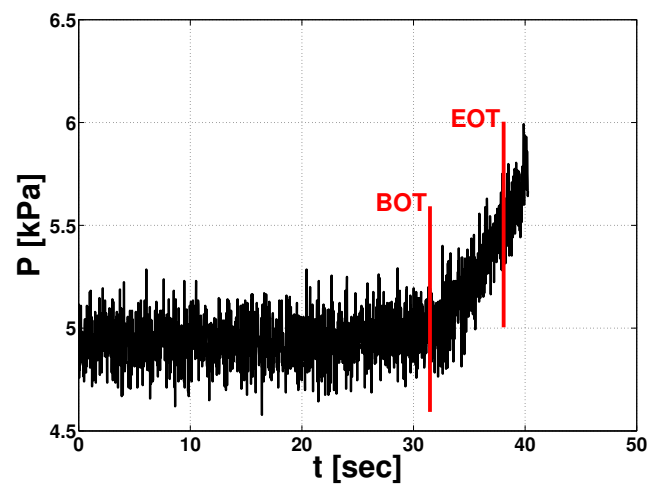

(f) $2^{\text {nd }}$ test at $96.53 \mathrm{kPa}$.

Figure F.26. Percolation pressure for VD328. The tests were conducted at three different compressions on the sample $41.37 \mathrm{kPa}, 68.95 \mathrm{kPa}, 96.53 \mathrm{kPa}$ while holding the flow rate constant at $18.75 \mathrm{E}-4 \mathrm{mLs}^{-1}$. 


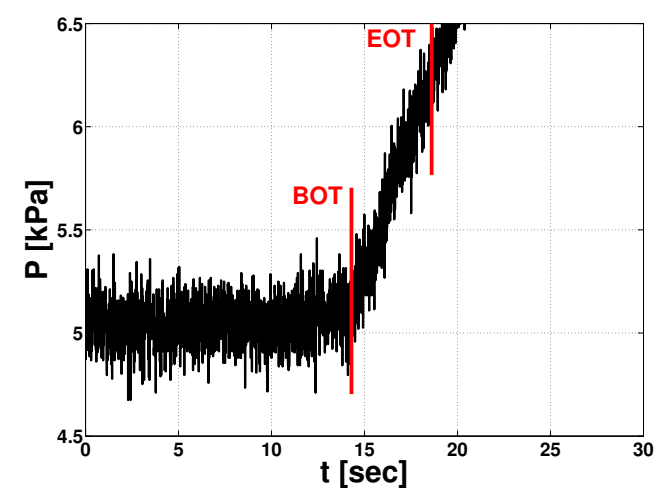

(a) $1^{\text {st }}$ test at $41.37 \mathrm{kPa}$.

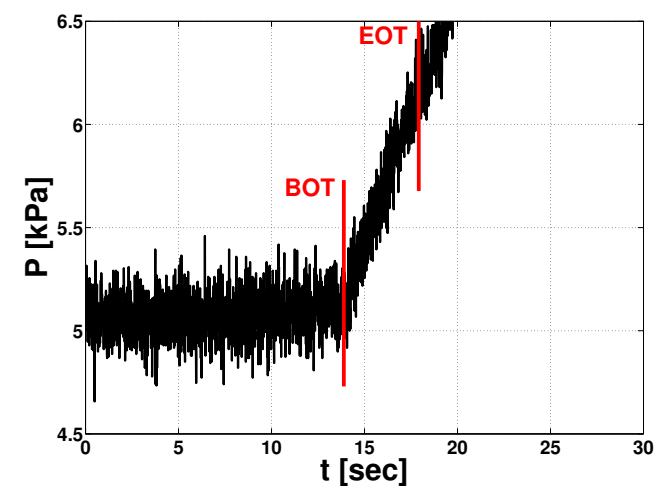

(c) $1^{\text {st }}$ test at $68.95 \mathrm{kPa}$.

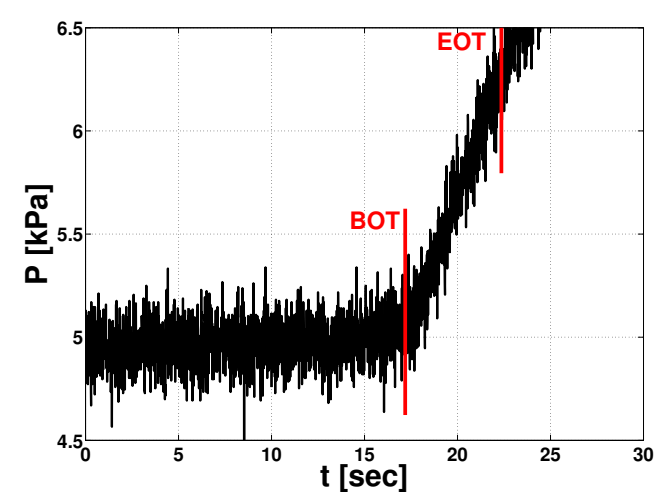

(e) $1^{\text {st }}$ test at $96.53 \mathrm{kPa}$.

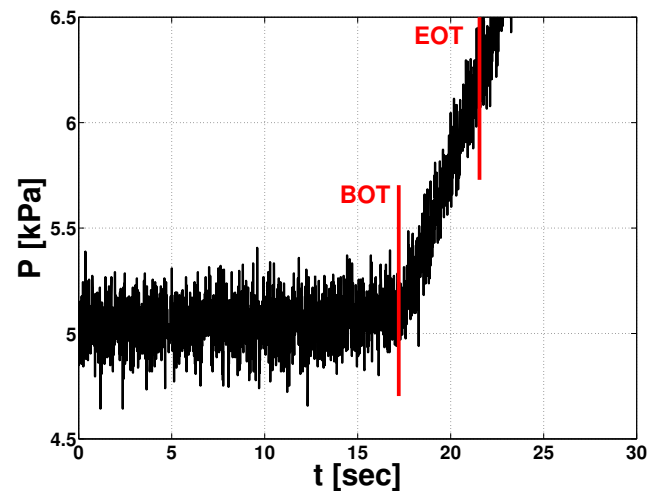

(b) $1^{\text {st }}$ test at $41.37 \mathrm{kPa}$.

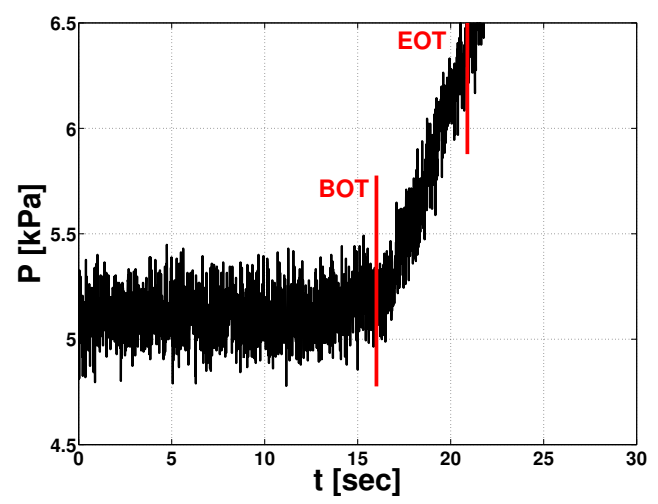

(d) $2^{\text {nd }}$ test at $68.95 \mathrm{kPa}$.

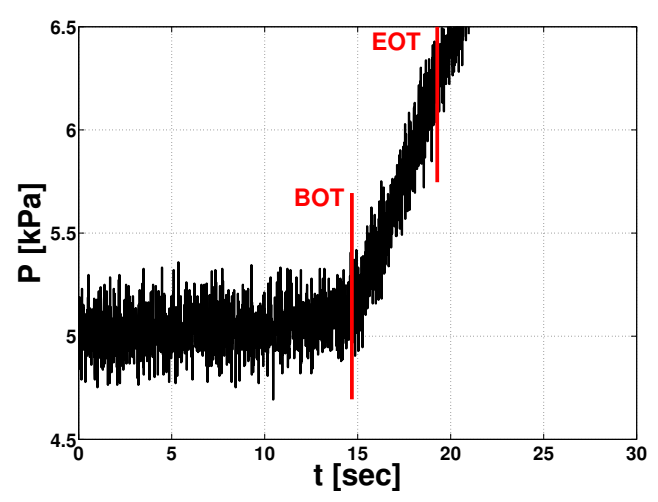

(f) $2^{\text {nd }}$ test at $96.53 \mathrm{kPa}$.

Figure F.27. Percolation pressure for VD328. The tests were conducted at three different compressions on the sample $41.37 \mathrm{kPa}, 68.95 \mathrm{kPa}, 96.53 \mathrm{kPa}$ while holding the flow rate constant at $37.08 \mathrm{E}-4 \mathrm{mLs}^{-1}$. 


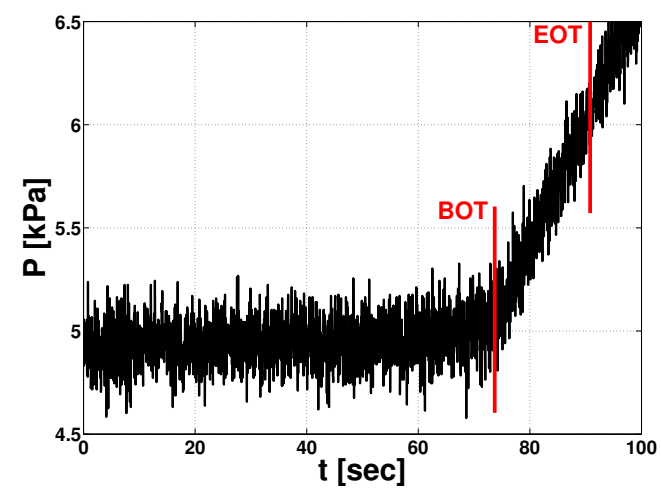

(a) $1^{\text {st }}$ test at $41.37 \mathrm{kPa}$.

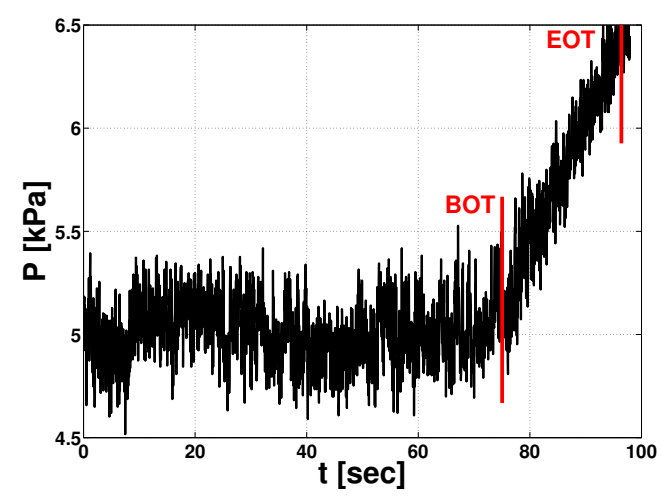

(c) $1^{\text {st }}$ test at $68.95 \mathrm{kPa}$.

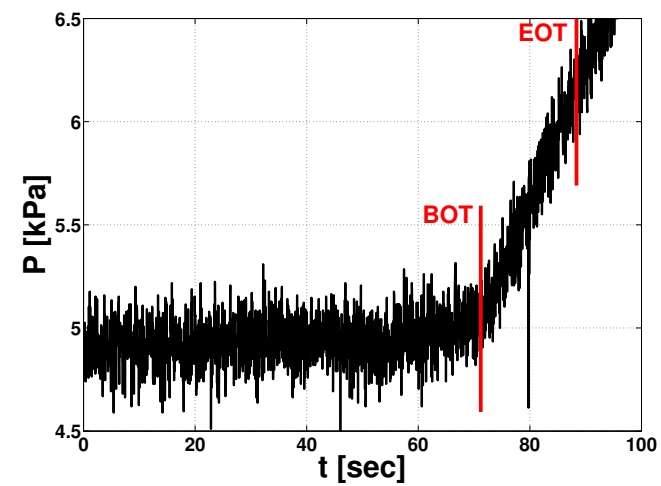

(e) $1^{\text {st }}$ test at $96.53 \mathrm{kPa}$.

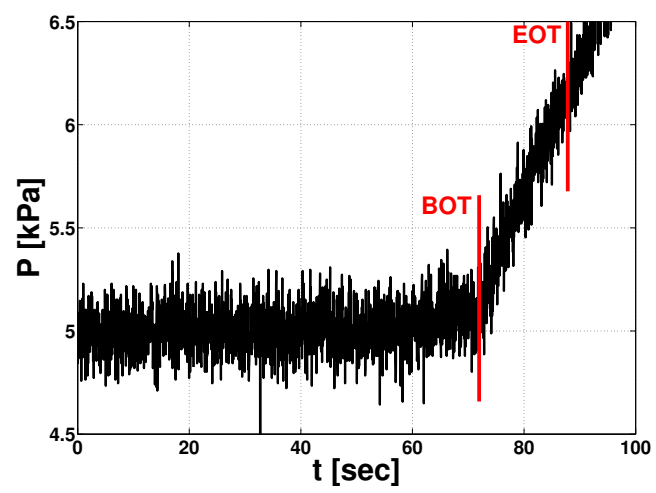

(b) $1^{\text {st }}$ test at $41.37 \mathrm{kPa}$.

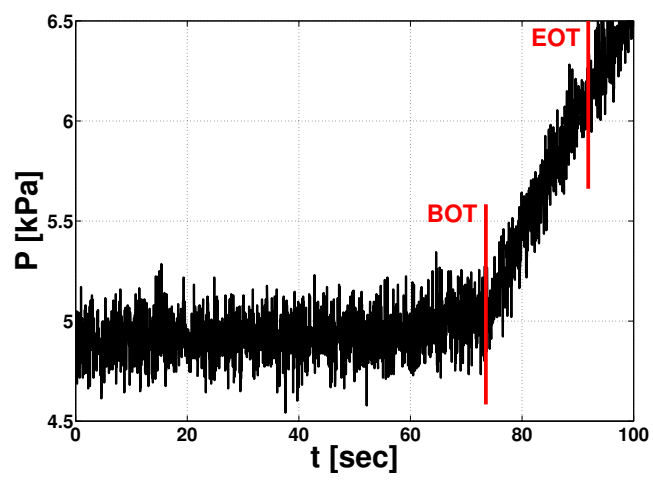

(d) $2^{\text {nd }}$ test at $68.95 \mathrm{kPa}$.

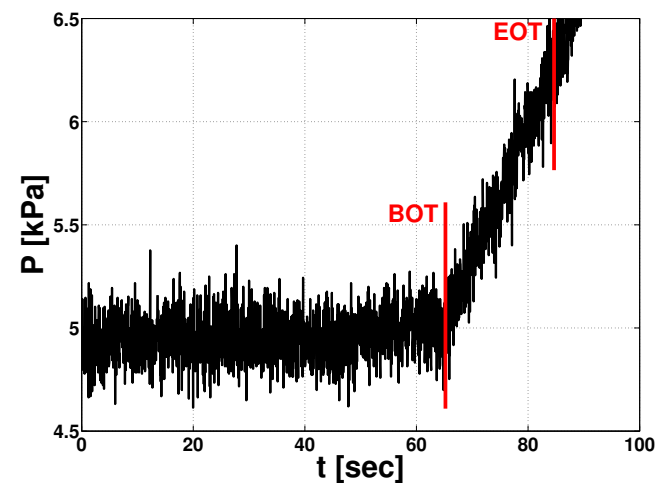

(f) $2^{\text {nd }}$ test at $96.53 \mathrm{kPa}$.

Figure F.28. Percolation pressure for VD302. The tests were conducted at three different compressions on the sample $41.37 \mathrm{kPa}, 68.95 \mathrm{kPa}, 96.53 \mathrm{kPa}$ while holding the flow rate constant at $9.48 \mathrm{E}-4 \mathrm{mLs}^{-1}$. 


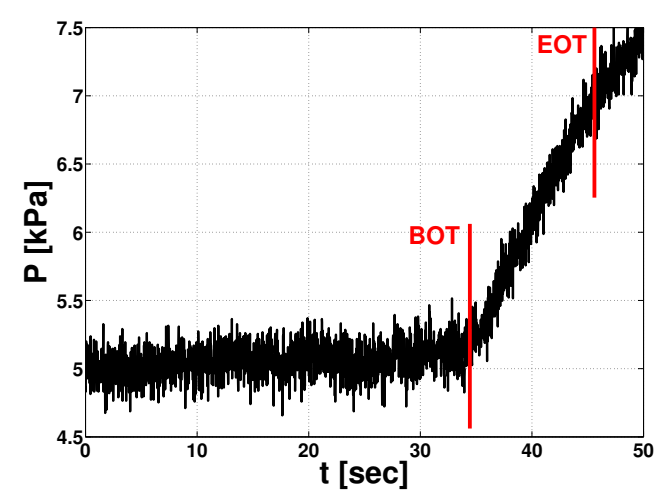

(a) $1^{\text {st }}$ test at $41.37 \mathrm{kPa}$.

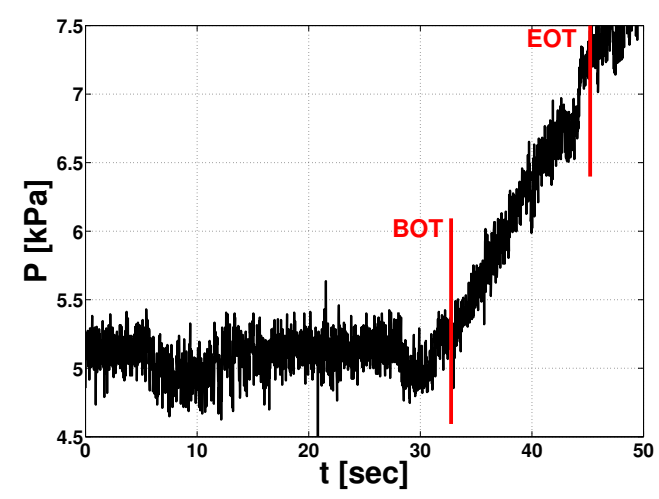

(c) $1^{\text {st }}$ test at $68.95 \mathrm{kPa}$.

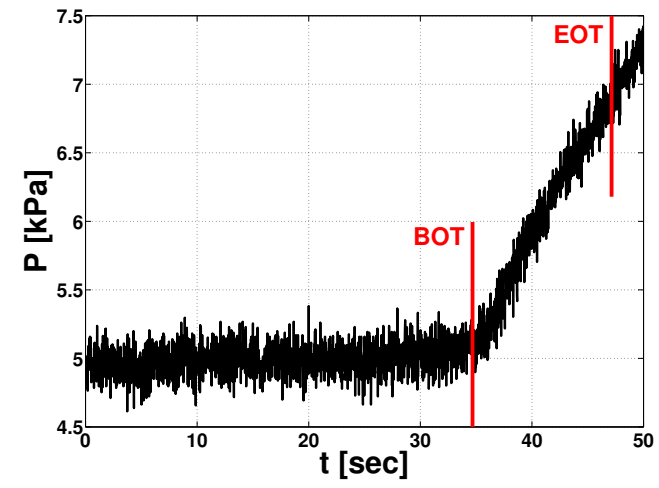

(e) $1^{\text {st }}$ test at $96.53 \mathrm{kPa}$.

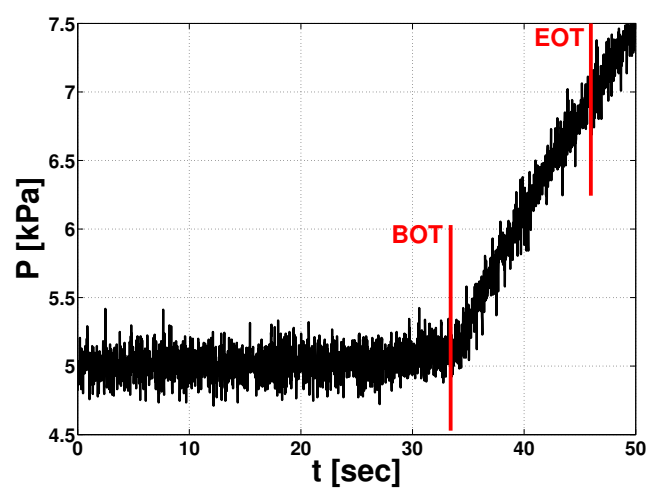

(b) $1^{\text {st }}$ test at $41.37 \mathrm{kPa}$.

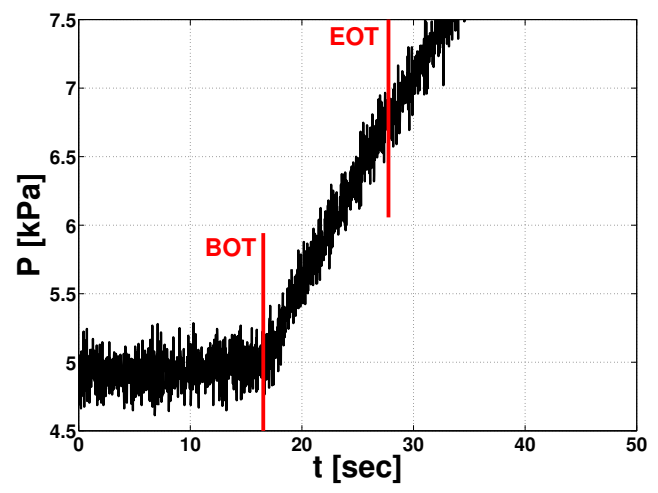

(d) $2^{\text {nd }}$ test at $68.95 \mathrm{kPa}$.

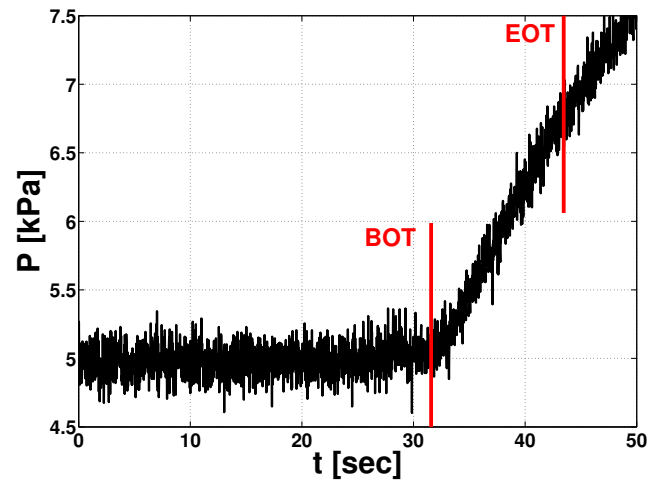

(f) $2^{\text {nd }}$ test at $96.53 \mathrm{kPa}$.

Figure F.29. Percolation pressure for VD302. The tests were conducted at three different compressions on the sample $41.37 \mathrm{kPa}, 68.95 \mathrm{kPa}, 96.53 \mathrm{kPa}$ while holding the flow rate constant at $18.75 \mathrm{E}-4 \mathrm{mLs}^{-1}$. 


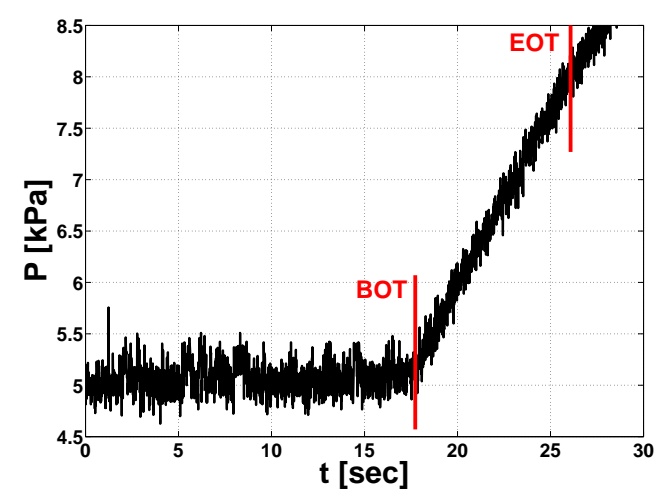

(a) $1^{\text {st }}$ test at $41.37 \mathrm{kPa}$.

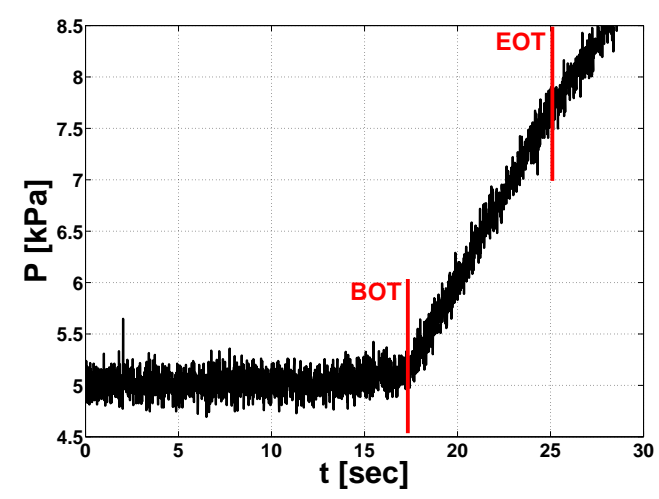

(c) $1^{\text {st }}$ test at $68.95 \mathrm{kPa}$.

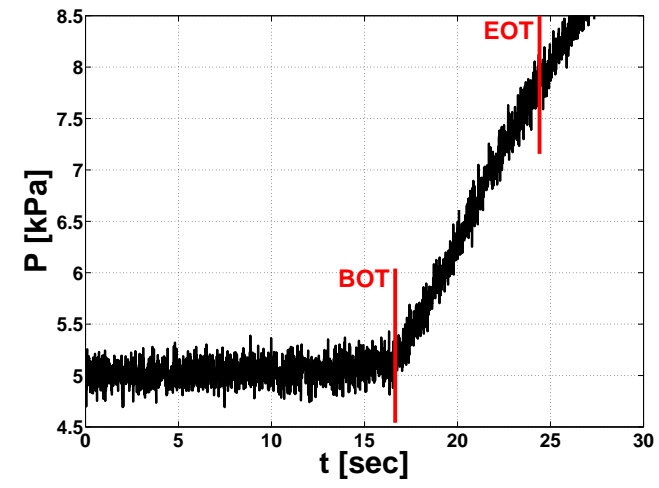

(e) $1^{\text {st }}$ test at $96.53 \mathrm{kPa}$.

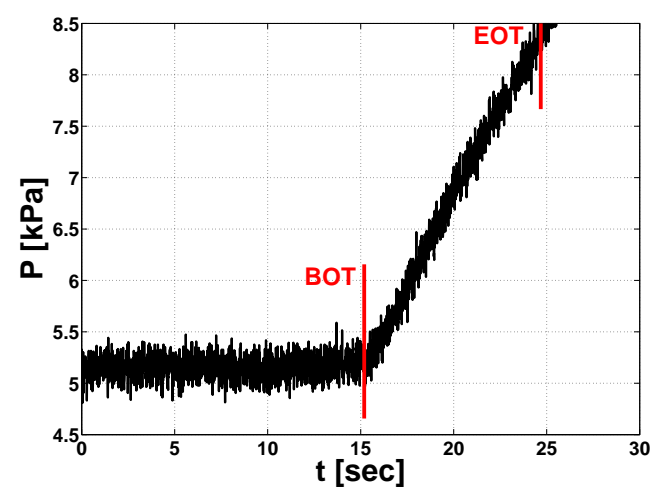

(b) $1^{\text {st }}$ test at $41.37 \mathrm{kPa}$.

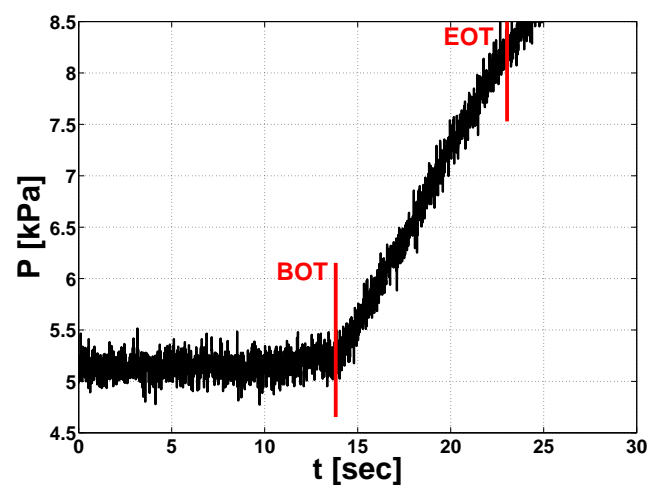

(d) $2^{\text {nd }}$ test at $68.95 \mathrm{kPa}$.

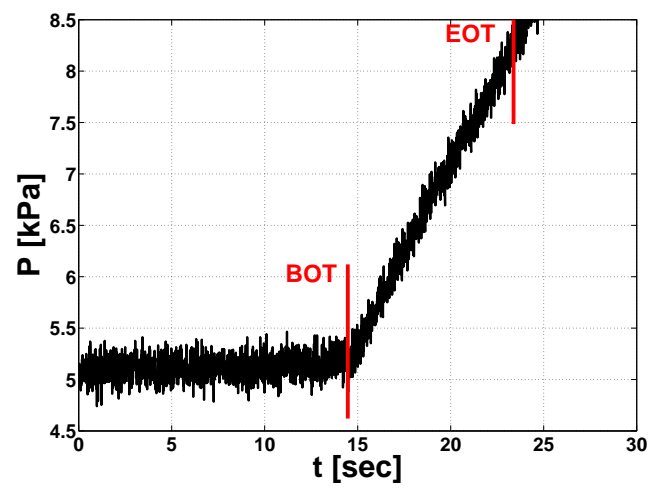

(f) $2^{\text {nd }}$ test at $96.53 \mathrm{kPa}$.

Figure F.30. Percolation pressure for VD302. The tests were conducted at three different compressions on the sample $41.37 \mathrm{kPa}, 68.95 \mathrm{kPa}, 96.53 \mathrm{kPa}$ while holding the flow rate constant at $37.08 \mathrm{E}-4 \mathrm{mLs}^{-1}$. 


\section{G. Full CCM Percolation Pressures}

Table G.1. Summary of VD420 Percolation Pressure tests. The BOT and EOT labeled here are to denote the begining of the test and end of the test. The slope is taken as the pressure difference over the time difference from the BOT to the EOT.

\begin{tabular}{|l|l|l|l|l|l|l|l|l|}
\hline $\begin{array}{l}\text { Pump } \\
\text { Speed } \\
\left(\mathrm{mLs}^{-1}\right)\end{array}$ & $\begin{array}{l}\text { Compression } \\
(\mathrm{kPa})\end{array}$ & $\begin{array}{l}\text { BOT } \\
(\mathrm{s})\end{array}$ & $\begin{array}{l}\text { BOT } \\
(\mathrm{kPa})\end{array}$ & EOT(s) $)$ & $\begin{array}{l}\text { EOT } \\
(\mathrm{kPa})\end{array}$ & $\begin{array}{l}\text { Time } \\
\text { Diff }(\mathrm{s})\end{array}$ & $\begin{array}{l}\text { Press } \\
\text { Diff } \\
(\mathrm{kPa})\end{array}$ & Slope \\
\hline & 41.37 & 17.6 & 5.03 & 27.1 & 8.34 & 9.5 & 3.31 & 0.35 \\
& 41.37 & 16 & 5.12 & 27.22 & 8.98 & 11.22 & 3.85 & 0.34 \\
$37.08 \mathrm{E}-4$ & 68.95 & 17.43 & 5.06 & 26.92 & 8.26 & 9.49 & 3.2 & 0.34 \\
& 68.95 & 14.82 & 5.18 & 25.18 & 8.72 & 10.36 & 3.54 & 0.34 \\
& 96.53 & 16.89 & 5.07 & 26.09 & 8.2 & 9.2 & 3.13 & 0.34 \\
& 96.53 & 13.29 & 5.12 & 23.08 & 8.47 & 9.79 & 3.35 & 0.34 \\
\hline & 41.37 & 36.26 & 4.96 & 51.98 & 7.6 & 15.72 & 2.64 & 0.17 \\
& 41.37 & 23.42 & 5.01 & 38.62 & 7.09 & 15.2 & 2.08 & 0.14 \\
$18.75 \mathrm{E}-4$ & 68.95 & 33.88 & 5 & 46.32 & 6.95 & 12.44 & 1.95 & 0.16 \\
& 68.95 & 26.76 & 5.06 & 41.96 & 7.26 & 15.2 & 2.2 & 0.15 \\
& 96.53 & 34.16 & 4.97 & 47.26 & 7.09 & 13.1 & 2.12 & 0.16 \\
& 96.53 & 34.84 & 5.05 & 46.76 & 6.77 & 11.92 & 1.72 & 0.15 \\
\hline & 41.37 & 64.33 & 4.97 & 84.19 & 6.21 & 19.86 & 1.24 & 0.06 \\
& 41.37 & 71.47 & 5.01 & 88.69 & 6.16 & 17.22 & 1.15 & 0.07 \\
& 68.95 & 72.02 & 5.02 & 94.44 & 6.62 & 22.42 & 1.6 & 0.07 \\
& 68.95 & 69.44 & 5 & 85.42 & 6.05 & 15.98 & 1.05 & 0.07 \\
& 96.53 & 71.3 & 4.94 & 89.76 & 6.16 & 18.46 & 1.22 & 0.07 \\
& 96.53 & 71.26 & 5.01 & 89.72 & 6.31 & 18.46 & 1.29 & 0.07 \\
\hline
\end{tabular}


Table G.2. Summary of VD421 Percolation Pressure tests. The BOT and EOT labeled here are to denote the begining of the test and end of the test. The slope is taken as the pressure difference over the time difference from the BOT to the EOT.

\begin{tabular}{|l|l|l|l|l|l|l|l|l|}
\hline $\begin{array}{l}\text { Pump } \\
\begin{array}{l}\text { Speed } \\
\left(\mathrm{mLs}^{-1}\right)\end{array}\end{array}$ & $\begin{array}{l}\text { Compression } \\
(\mathrm{kPa})\end{array}$ & $\begin{array}{l}\text { BOT } \\
(\mathrm{s})\end{array}$ & $\begin{array}{l}\text { BOT } \\
(\mathrm{kPa})\end{array}$ & EOT(s) & $\begin{array}{l}\text { EOT } \\
(\mathrm{kPa})\end{array}$ & $\begin{array}{l}\text { Time } \\
\text { Diff }(\mathrm{s})\end{array}$ & $\begin{array}{l}\text { Press } \\
\text { Diff } \\
(\mathrm{kPa})\end{array}$ & Slope \\
\hline & 41.37 & 17.4 & 5.17 & 22.88 & 6.89 & 5.48 & 1.72 & 0.31 \\
$37.08 \mathrm{E}-4$ & 41.37 & 15.43 & 5.06 & 20.89 & 6.64 & 5.46 & 1.58 & 0.29 \\
& 68.95 & 17.48 & 5.17 & 23.25 & 7 & 5.77 & 1.83 & 0.32 \\
& 68.95 & 15.35 & 5.11 & 20.53 & 6.57 & 5.18 & 1.47 & 0.28 \\
& 96.53 & 17.6 & 5.03 & 23.06 & 6.94 & 5.46 & 1.91 & 0.35 \\
& 96.53 & 14.92 & 5.15 & 23.54 & 7.77 & 8.62 & 2.62 & 0.3 \\
\hline & 41.37 & 36.48 & 5.09 & 43.72 & 6.05 & 7.24 & 0.96 & 0.13 \\
& 41.37 & 31.06 & 5.01 & 42.94 & 6.46 & 11.88 & 1.45 & 0.12 \\
& 68.95 & 36.58 & 5.01 & 44.5 & 6.18 & 7.92 & 1.17 & 0.15 \\
& 68.95 & 11.16 & 5.03 & 21.72 & 6.37 & 10.56 & 1.34 & 0.13 \\
& 96.53 & 34.34 & 4.93 & 44.82 & 6.37 & 10.48 & 1.44 & 0.14 \\
& 96.53 & 33.06 & 4.91 & 41 & 5.89 & 7.94 & 0.97 & 0.12 \\
\hline \multirow{5}{*}{$9.48 \mathrm{E}-4$} & 41.37 & 78.23 & 4.88 & 88.83 & 5.49 & 10.6 & 0.61 & 0.06 \\
& 41.37 & 72.49 & 4.97 & 83.08 & 5.48 & 10.6 & 0.51 & 0.05 \\
& 68.95 & 71.89 & 5.01 & 81.07 & 5.47 & 9.17 & 0.47 & 0.05 \\
& 68.95 & 51.51 & 4.98 & 63.4 & 5.58 & 11.89 & 0.6 & 0.05 \\
& 96.53 & 72.15 & 4.89 & 86.65 & 5.75 & 14.51 & 0.86 & 0.06 \\
& 96.53 & 70.03 & 5.04 & 85.76 & 5.99 & 15.72 & 0.95 & 0.06 \\
\hline
\end{tabular}


Table G.3. Summary of VD423 Percolation Pressure tests. The BOT and EOT labeled here are to denote the begining of the test and end of the test. The slope is taken as the pressure difference over the time difference from the BOT to the EOT.

\begin{tabular}{|l|l|l|l|l|l|l|l|c|}
\hline $\begin{array}{l}\text { Pump } \\
\begin{array}{l}\text { Speed } \\
\left(\mathrm{mLs}^{-1}\right)\end{array}\end{array}$ & $\begin{array}{l}\text { Compression } \\
(\mathrm{kPa})\end{array}$ & $\begin{array}{l}\text { BOT } \\
(\mathrm{s})\end{array}$ & $\begin{array}{l}\text { BOT } \\
(\mathrm{kPa})\end{array}$ & EOT(s) & $\begin{array}{l}\text { EOT } \\
(\mathrm{kPa})\end{array}$ & $\begin{array}{l}\text { Time } \\
\text { Diff }(\mathrm{s})\end{array}$ & $\begin{array}{l}\text { Press } \\
\text { Diff } \\
(\mathrm{kPa})\end{array}$ & Slope \\
\hline & 41.37 & 17.65 & 5.17 & 25.13 & 8.15 & 7.48 & 2.99 & 0.4 \\
$37.08 \mathrm{E}-4$ & 41.37 & 15.7 & 5.2 & 25.4 & 9.01 & 9.76 & 3.81 & 0.39 \\
& 68.95 & 16.91 & 5.15 & 25.24 & 8.48 & 8.33 & 3.33 & 0.4 \\
& 68.95 & 14.49 & 5.25 & 22.26 & 8.2 & 7.77 & 2.95 & 0.38 \\
& 96.53 & 15.34 & 5.13 & 23.97 & 8.59 & 8.63 & 3.46 & 0.4 \\
& 96.53 & 15.48 & 5.39 & 25.82 & 9.59 & 10.34 & 4.2 & 0.41 \\
\hline & 41.37 & 35.02 & 5.19 & 46.8 & 7.42 & 11.78 & 2.23 & 0.19 \\
& 41.37 & 32.46 & 5.06 & 44.36 & 7.07 & 11.9 & 2.02 & 0.17 \\
& 68.95 & 34.52 & 5.03 & 47.64 & 7.6 & 13.12 & 2.58 & 0.2 \\
& 68.95 & 24.64 & 5.08 & 36.52 & 7.38 & 11.88 & 2.29 & 0.19 \\
& 96.53 & 33.58 & 5.02 & 42.08 & 6.72 & 8.5 & 1.7 & 0.2 \\
& 96.53 & 30.06 & 5.1 & 39.98 & 6.81 & 9.92 & 1.71 & 0.17 \\
\hline \multirow{5}{*}{$9.48 \mathrm{E}-4$} & 41.37 & 73.75 & 4.98 & 92.22 & 6.67 & 18.46 & 1.69 & 0.09 \\
& 41.37 & 71.3 & 5.03 & 87.03 & 6.36 & 15.72 & 1.33 & 0.09 \\
& 68.95 & 71.56 & 5.04 & 88.59 & 6.56 & 17.03 & 1.52 & 0.09 \\
& 68.95 & 37.81 & 5.03 & 53.64 & 6.37 & 15.82 & 1.35 & 0.09 \\
& 96.53 & 70.96 & 4.94 & 84.21 & 6.08 & 13.24 & 1.14 & 0.09 \\
& 96.53 & 71.94 & 5.02 & 88.97 & 6.5 & 17.03 & 1.48 & 0.09 \\
\hline
\end{tabular}


Table G.4. Summary of VD422 Percolation Pressure tests. The BOT and EOT labeled here are to denote the begining of the test and end of the test. The slope is taken as the pressure difference over the time difference from the BOT to the EOT.

\begin{tabular}{|l|l|l|l|l|l|l|l|c|}
\hline $\begin{array}{l}\text { Pump } \\
\text { Speed } \\
\left(\mathrm{mLs}^{-1}\right)\end{array}$ & $\begin{array}{l}\text { Compression } \\
(\mathrm{kPa})\end{array}$ & $\begin{array}{l}\text { BOT } \\
(\mathrm{s})\end{array}$ & $\begin{array}{l}\text { BOT } \\
(\mathrm{kPa})\end{array}$ & EOT(s) & $\begin{array}{l}\text { EOT } \\
(\mathrm{kPa})\end{array}$ & $\begin{array}{l}\text { Time } \\
\text { Diff }(\mathrm{s})\end{array}$ & $\begin{array}{l}\text { Press } \\
\text { Diff } \\
(\mathrm{kPa})\end{array}$ & Slope \\
\hline & 41.37 & 18.18 & 6.2 & 47.24 & 20.99 & 29.06 & 14.79 & 0.51 \\
& 41.37 & 16.87 & 6.62 & 48.5 & 22.14 & 31.63 & 15.53 & 0.49 \\
$37.08 \mathrm{E}-4$ & 68.95 & 17.56 & 6.12 & 44.62 & 19.28 & 27.06 & 13.16 & 0.49 \\
& 68.95 & 13.91 & 6.8 & 49.01 & 24.29 & 35.1 & 17.49 & 0.5 \\
& 96.53 & 20.36 & 6.3 & 53.73 & 23.7 & 33.37 & 17.4 & 0.52 \\
& 96.53 & 15.37 & 6.28 & 41.51 & 18.22 & 26.14 & 11.94 & 0.46 \\
\hline \multirow{5}{*}{$18.75 \mathrm{E}-4$} & 41.37 & 32.66 & 5.63 & 77.96 & 16.22 & 45.3 & 10.59 & 0.23 \\
& 41.37 & 29.5 & 5.7 & 78.36 & 16.75 & 48.86 & 11.06 & 0.23 \\
& 68.95 & 35.58 & 5.53 & 76.4 & 15.13 & 40.82 & 9.6 & 0.24 \\
& 68.95 & 13.2 & 5.92 & 58.76 & 16.37 & 45.56 & 10.44 & 0.23 \\
& 96.53 & 34.3 & 5.59 & 77.65 & 15.93 & 43.35 & 10.34 & 0.24 \\
& 96.53 & 30.62 & 5.55 & 73.54 & 15.056 & 42.92 & 9.51 & 0.22 \\
\hline \multirow{5}{*}{$9.48 \mathrm{E}-4$} & 41.37 & 69.86 & 5.29 & 136.13 & 12.43 & 66.27 & 7.15 & 0.11 \\
& 41.37 & 67.83 & 5.3 & 131.12 & 12.18 & 63.3 & 6.88 & 0.11 \\
& 68.95 & 70.82 & 5.33 & 136.05 & 12.4 & 65.24 & 7.07 & 0.11 \\
& 68.95 & 70.8 & 5.3 & 141.4 & 12.62 & 70.6 & 7.32 & 0.1 \\
& 96.53 & 83.76 & 5.21 & 148.03 & 12.36 & 64.27 & 7.15 & 0.11 \\
& 96.53 & 62.45 & 5.46 & 139.13 & 13.69 & 76.68 & 8.23 & 0.11 \\
\hline
\end{tabular}


Table G.5. Summary of VD424 Percolation Pressure tests. The BOT and EOT labeled here are to denote the begining of the test and end of the test. The slope is taken as the pressure difference over the time difference from the BOT to the EOT.

\begin{tabular}{|l|l|l|l|l|l|l|l|c|}
\hline $\begin{array}{l}\text { Pump } \\
\begin{array}{l}\text { Speed } \\
\left(\mathrm{mLs}^{-1}\right)\end{array}\end{array}$ & $\begin{array}{l}\text { Compression } \\
(\mathrm{kPa})\end{array}$ & $\begin{array}{l}\text { BOT } \\
(\mathrm{s})\end{array}$ & $\begin{array}{l}\text { BOT } \\
(\mathrm{kPa})\end{array}$ & EOT(s) & $\begin{array}{l}\text { EOT } \\
(\mathrm{kPa})\end{array}$ & $\begin{array}{l}\text { Time } \\
\text { Diff }(\mathrm{s})\end{array}$ & $\begin{array}{l}\text { Press } \\
\text { Diff } \\
(\mathrm{kPa})\end{array}$ & Slope \\
\hline & 41.37 & 17.36 & 5.16 & 25.71 & 8.49 & 8.35 & 3.33 & 0.4 \\
$37.08 \mathrm{E}-4$ & 41.37 & 15.06 & 5.39 & 25.41 & 9.55 & 10.35 & 4.16 & 0.4 \\
& 68.95 & 17.28 & 5.2 & 27.63 & 9.4 & 10.35 & 4.21 & 0.41 \\
& 68.95 & 14.74 & 5.43 & 24.23 & 9.27 & 9.49 & 3.84 & 0.41 \\
& 96.53 & 16.82 & 5.23 & 27.17 & 9.39 & 10.35 & 4.16 & 0.4 \\
& 96.53 & 15.52 & 5.46 & 26.71 & 10.03 & 11.19 & 4.57 & 0.41 \\
\hline & 41.37 & 34.6 & 5.21 & 47.04 & 7.62 & 12.44 & 2.42 & 0.19 \\
& 41.37 & 32.86 & 5.12 & 46.72 & 7.74 & 13.86 & 2.62 & 0.19 \\
& 68.95 & 34.34 & 5.17 & 47.46 & 7.64 & 13.12 & 2.47 & 0.19 \\
& 68.95 & 18.94 & 5.17 & 37.42 & 8.8 & 18.48 & 3.63 & 0.2 \\
& 96.53 & 35.18 & 5.12 & 48.3 & 7.97 & 13.12 & 2.85 & 0.22 \\
& 96.53 & 31.78 & 5.18 & 45.66 & 7.68 & 13.88 & 2.5 & 0.18 \\
\hline \multirow{5}{*}{$9.48 \mathrm{E}-4$} & 41.37 & 70.96 & 4.99 & 89.5 & 6.59 & 18.54 & 1.6 & 0.09 \\
& 41.37 & 71.3 & 5.06 & 89.84 & 6.76 & 18.54 & 1.7 & 0.09 \\
& 68.95 & 71.97 & 5.06 & 89.11 & 6.69 & 17.14 & 1.62 & 0.1 \\
& 68.95 & 55.22 & 5.05 & 72.36 & 6.47 & 17.14 & 1.42 & 0.08 \\
& 96.53 & 72.17 & 4.98 & 103.82 & 7.92 & 31.65 & 2.95 & 0.09 \\
& 96.53 & 70.91 & 5.09 & 99.64 & 7.68 & 8.73 & 2.59 & 0.09 \\
\hline
\end{tabular}


Table G.6. Summary of VD425 Percolation Pressure tests. The BOT and EOT labeled here are to denote the begining of the test and end of the test. The slope is taken as the pressure difference over the time difference from the BOT to the EOT.

\begin{tabular}{|l|l|l|l|l|l|l|l|l|}
\hline $\begin{array}{l}\text { Pump } \\
\text { Speed } \\
\left(\mathrm{mLs}^{-1}\right)\end{array}$ & $\begin{array}{l}\text { Compression } \\
(\mathrm{kPa})\end{array}$ & $\begin{array}{l}\text { BOT } \\
(\mathrm{s})\end{array}$ & $\begin{array}{l}\text { BOT } \\
(\mathrm{kPa})\end{array}$ & EOT(s) $)$ & $\begin{array}{l}\text { EOT } \\
(\mathrm{kPa})\end{array}$ & $\begin{array}{l}\text { Time } \\
\text { Diff }(\mathrm{s})\end{array}$ & $\begin{array}{l}\text { Press } \\
\text { Diff } \\
(\mathrm{kPa})\end{array}$ & Slope \\
\hline & 41.37 & 18.23 & 5.9 & 40.69 & 16.26 & 22.46 & 10.36 & 0.46 \\
$37.08 \mathrm{E}-4$ & 41.37 & 16.41 & 5.94 & 39.7 & 16.23 & 23.29 & 10.29 & 0.44 \\
& 68.95 & 17.67 & 5.75 & 36.71 & 14.09 & 19.04 & 8.35 & 0.44 \\
& 68.95 & 15.4 & 6.31 & 43.02 & 18.8 & 27.62 & 12.5 & 0.45 \\
& 96.53 & 17.84 & 6.09 & 43.44 & 18.25 & 25.6 & 12.17 & 0.48 \\
& 96.53 & 16.45 & 6.45 & 49.48 & 22 & 33.03 & 15.55 & 0.47 \\
\hline & 41.37 & 34.16 & 5.53 & 69.68 & 13.06 & 35.52 & 7.54 & 0.21 \\
& 41.37 & 33.42 & 5.4 & 67.76 & 12.67 & 34.34 & 7.27 & 0.21 \\
$18.75 \mathrm{E}-4$ & 68.95 & 35.86 & 5.32 & 68.82 & 12.41 & 32.96 & 7.09 & 0.22 \\
& 68.95 & 16.74 & 5.41 & 49.76 & 12.25 & 33.02 & 6.84 & 0.21 \\
& 96.53 & 34.6 & 5.39 & 71.3 & 13.69 & 36.7 & 8.29 & 0.23 \\
& 96.53 & 32.26 & 5.4 & 71.26 & 13.42 & 39 & 8.02 & 0.21 \\
\hline & 41.37 & 70.82 & 5.09 & 120.93 & 9.94 & 50.11 & 4.85 & 0.1 \\
& 41.37 & 70.06 & 5.18 & 121.15 & 10.34 & 51.1 & 5.16 & 0.1 \\
& 68.95 & 68.77 & 5.25 & 128.42 & 11.28 & 59.65 & 6.03 & 0.1 \\
& 68.95 & 49.65 & 5.22 & 110.44 & 11.12 & 60.79 & 5.9 & 0.1 \\
& 96.53 & 69.88 & 5.05 & 116.13 & 9.67 & 46.25 & 4.62 & 0.1 \\
& 96.53 & 68.64 & 5.34 & 133.73 & 11.8 & 65.09 & 6.46 & 0.1 \\
\hline
\end{tabular}


Table G.7. Summary of VD432 Percolation Pressure tests. The BOT and EOT labeled here are to denote the begining of the test and end of the test. The slope is taken as the pressure difference over the time difference from the BOT to the EOT.

\begin{tabular}{|l|l|l|l|l|l|l|l|c|}
\hline $\begin{array}{l}\text { Pump } \\
\begin{array}{l}\text { Speed } \\
\left(\mathrm{mLs}^{-1}\right)\end{array}\end{array}$ & $\begin{array}{l}\text { Compression } \\
(\mathrm{kPa})\end{array}$ & $\begin{array}{l}\text { BOT } \\
(\mathrm{s})\end{array}$ & $\begin{array}{l}\text { BOT } \\
(\mathrm{kPa})\end{array}$ & EOT(s) & $\begin{array}{l}\text { EOT } \\
(\mathrm{kPa})\end{array}$ & $\begin{array}{l}\text { Time } \\
\text { Diff }(\mathrm{s})\end{array}$ & $\begin{array}{l}\text { Press } \\
\text { Diff } \\
(\mathrm{kPa})\end{array}$ & Slope \\
\hline & 41.37 & 16.82 & 5.46 & 39.56 & 15.82 & 22.74 & 10.36 & 0.46 \\
$37.08 \mathrm{E}-4$ & 41.37 & 14.87 & 5.77 & 37.31 & 15.58 & 22.44 & 9.81 & 0.44 \\
& 68.95 & 17.37 & 5.7 & 41.83 & 17.34 & 24.46 & 11.64 & 0.48 \\
& 68.95 & 14.85 & 6.08 & 46.21 & 20.73 & 31.36 & 14.64 & 0.47 \\
& 96.53 & 18.3 & 5.69 & 44.77 & 18.35 & 26.47 & 12.66 & 0.48 \\
& 96.53 & 14.18 & 5.88 & 40.92 & 17.99 & 26.74 & 12.11 & 0.45 \\
\hline & 41.37 & 35.84 & 5.28 & 68.06 & 12.19 & 32.22 & 6.91 & 0.22 \\
& 41.37 & 31.88 & 5.405 & 72.82 & 14.33 & 40.94 & 8.93 & 0.22 \\
& 68.95 & 35.56 & 5.25 & 73.04 & 13.76 & 37.48 & 8.51 & 0.23 \\
& 68.95 & 14.92 & 5.06 & 49.28 & 12.01 & 34.36 & 6.96 & 0.2 \\
& 96.53 & 34.58 & 5.33 & 72.58 & 14.14 & 38 & 8.81 & 0.23 \\
& 96.53 & 32.06 & 5.32 & 71.02 & 13.58 & 38.96 & 8.26 & 0.21 \\
\hline \multirow{5}{*}{$9.48 \mathrm{E}-4$} & 41.37 & 68.34 & 5.16 & 129.31 & 11.41 & 60.97 & 6.25 & 0.1 \\
& 41.37 & 70.8 & 5.19 & 133.1 & 11.7 & 62.3 & 6.51 & 0.11 \\
& 68.95 & 70.12 & 5.23 & 123.49 & 10.83 & 53.37 & 5.59 & 0.11 \\
& 68.95 & 71.54 & 5.15 & 115.8 & 9.58 & 44.26 & 4.43 & 0.1 \\
& 96.53 & 67.52 & 5.17 & 128.76 & 11.71 & 61.24 & 6.55 & 0.11 \\
& 96.53 & 69.05 & 5.17 & 120.4 & 10.39 & 51.35 & 5.22 & 0.1 \\
\hline
\end{tabular}


Table G.8. Summary of VD436 Percolation Pressure tests. The BOT and EOT labeled here are to denote the begining of the test and end of the test. The slope is taken as the pressure difference over the time difference from the BOT to the EOT.

\begin{tabular}{|l|l|l|l|l|l|l|l|l|}
\hline $\begin{array}{l}\text { Pump } \\
\begin{array}{l}\text { Speed } \\
\left(\mathrm{mLs}^{-1}\right)\end{array}\end{array}$ & $\begin{array}{l}\text { Compression } \\
(\mathrm{kPa})\end{array}$ & $\begin{array}{l}\text { BOT } \\
(\mathrm{s})\end{array}$ & $\begin{array}{l}\text { BOT } \\
(\mathrm{kPa})\end{array}$ & EOT(s) & $\begin{array}{l}\text { EOT } \\
(\mathrm{kPa})\end{array}$ & $\begin{array}{l}\text { Time } \\
\text { Diff }(\mathrm{s})\end{array}$ & $\begin{array}{l}\text { Press } \\
\text { Diff } \\
(\mathrm{kPa})\end{array}$ & Slope \\
\hline & 41.37 & 16.86 & 5.04 & 22.9 & 6.82 & 6.04 & 1.78 & 0.29 \\
$37.08 \mathrm{E}-4$ & 41.37 & 15.03 & 5.08 & 22.8 & 7.46 & 7.77 & 2.38 & 0.31 \\
& 68.95 & 17.25 & 4.99 & 23 & 6.89 & 5.75 & 1.9 & 0.33 \\
& 68.95 & 15.29 & 5.12 & 22.48 & 7.36 & 7.19 & 2.25 & 0.31 \\
& 96.53 & 17.19 & 5.01 & 24.38 & 7.28 & 7.19 & 2.27 & 0.32 \\
& 96.53 & 14 & 5.07 & 22.33 & 7.7 & 8.33 & 2.63 & 0.32 \\
\hline & 41.37 & 34.88 & 4.96 & 44.08 & 6.13 & 9.2 & 1.18 & 0.13 \\
& 41.37 & 32.52 & 5.01 & 41.76 & 6.18 & 9.24 & 1.17 & 0.13 \\
& 68.95 & 34.64 & 4.93 & 43.18 & 6.08 & 8.54 & 1.15 & 0.13 \\
& 68.95 & 11.86 & 4.93 & 21.12 & 6.11 & 9.26 & 1.19 & 0.13 \\
& 96.53 & 34.26 & 4.96 & 43.44 & 6.32 & 9.18 & 1.36 & 0.15 \\
& 96.53 & 32.18 & 4.96 & 41.42 & 6.03 & 9.24 & 1.07 & 0.12 \\
\hline \multirow{5}{*}{$9.75 \mathrm{E}-4$} & 41.37 & 71.98 & 4.97 & 83.9 & 5.66 & 11.92 & 0.68 & 0.06 \\
& 41.37 & 67.98 & 5.04 & 79.84 & 5.69 & 11.87 & 0.66 & 0.06 \\
& 68.95 & 72.77 & 5.07 & 83.36 & 5.57 & 10.59 & 0.5 & 0.05 \\
& 68.95 & 69.5 & 5 & 79.84 & 5.56 & 10.35 & 0.56 & 0.05 \\
& 96.53 & 71.17 & 4.96 & 87 & 5.97 & 15.82 & 1.01 & 0.06 \\
& 96.53 & 73.93 & 4.96 & 84.35 & 5.74 & 10.42 & 0.79 & 0.08 \\
\hline
\end{tabular}


Table G.9. Summary of VD328 Percolation Pressure tests. The BOT and EOT labeled here are to denote the begining of the test and end of the test. The slope is taken as the pressure difference over the time difference from the BOT to the EOT.

\begin{tabular}{|l|l|l|l|l|l|l|l|c|}
\hline $\begin{array}{l}\text { Pump } \\
\text { Speed } \\
\left(\mathrm{mLs}^{-1}\right)\end{array}$ & $\begin{array}{l}\text { Compression } \\
(\mathrm{kPa})\end{array}$ & $\begin{array}{l}\text { BOT } \\
(\mathrm{s})\end{array}$ & $\begin{array}{l}\text { BOT } \\
(\mathrm{kPa})\end{array}$ & EOT(s) & $\begin{array}{l}\text { EOT } \\
(\mathrm{kPa})\end{array}$ & $\begin{array}{l}\text { Time } \\
\text { Diff }(\mathrm{s})\end{array}$ & $\begin{array}{l}\text { Press } \\
\text { Diff } \\
(\mathrm{kPa})\end{array}$ & Slope \\
\hline & 41.37 & 14.3 & 5.05 & 18.61 & 6.27 & 4.31 & 1.21 & 0.28 \\
& 41.37 & 17.21 & 5.05 & 21.55 & 6.23 & 4.34 & 1.18 & 0.27 \\
& 68.95 & 13.89 & 5.08 & 17.92 & 6.18 & 4.03 & 1.1 & 0.27 \\
& 68.95 & 16.01 & 5.13 & 20.9 & 6.38 & 4.89 & 1.25 & 0.26 \\
& 96.53 & 17.19 & 4.97 & 22.36 & 6.3 & 5.17 & 1.32 & 0.26 \\
& 96.53 & 14.69 & 5.04 & 19.28 & 6.25 & 4.59 & 1.2 & 0.26 \\
\hline & 41.37 & 34.16 & 4.98 & 40.72 & 5.59 & 6.56 & 0.61 & 0.09 \\
& 41.37 & 33.02 & 5 & 39.64 & 5.65 & 6.62 & 0.65 & 0.1 \\
& 68.95 & 35.24 & 4.97 & 42.46 & 5.68 & 7.22 & 0.72 & 0.1 \\
& 68.95 & 12.42 & 4.91 & 19.68 & 5.49 & 7.26 & 0.58 & 0.08 \\
& 96.53 & 35.24 & 4.95 & 42.44 & 5.7 & 7.2 & 0.75 & 0.1 \\
& 96.53 & 31.48 & 4.94 & 38.08 & 5.5 & 6.6 & 0.56 & 0.09 \\
\hline \multirow{5}{*}{$9.48 \mathrm{E}-4$} & 41.37 & 70.2 & 4.96 & 79.45 & 5.12 & 9.25 & 0.17 & 0.02 \\
& 41.37 & 66.52 & 4.98 & 77.09 & 5.22 & 10.57 & 0.24 & 0.02 \\
& 68.95 & 70.83 & 4.95 & 80.04 & 5.11 & 9.21 & 0.15 & 0.02 \\
& 68.95 & 70.69 & 4.94 & 81.18 & 5.19 & 10.5 & 0.25 & 0.02 \\
& 96.53 & 63.67 & 4.95 & 75.54 & 5.33 & 11.87 & 0.38 & 0.03 \\
& 96.53 & 65.22 & 4.94 & 74.27 & 5.06 & 9.05 & 0.12 & 0.01 \\
\hline
\end{tabular}


Table G.10. Summary of VD302 Percolation Pressure tests. The BOT and EOT labeled here are to denote the begining of the test and end of the test. The slope is taken as the pressure difference over the time difference from the BOT to the EOT.

\begin{tabular}{|l|l|l|l|l|l|l|l|l|}
\hline $\begin{array}{l}\text { Pump } \\
\begin{array}{l}\text { Speed } \\
\left(\mathrm{mLs}^{-1}\right)\end{array}\end{array}$ & $\begin{array}{l}\text { Compression } \\
(\mathrm{kPa})\end{array}$ & $\begin{array}{l}\text { BOT } \\
(\mathrm{s})\end{array}$ & $\begin{array}{l}\text { BOT } \\
(\mathrm{kPa})\end{array}$ & EOT(s) & $\begin{array}{l}\text { EOT } \\
(\mathrm{kPa})\end{array}$ & $\begin{array}{l}\text { Time } \\
\text { Diff }(\mathrm{s})\end{array}$ & $\begin{array}{l}\text { Press } \\
\text { Diff } \\
(\mathrm{kPa})\end{array}$ & Slope \\
\hline & 41.37 & 17.73 & 5.07 & 26.08 & 8.02 & 8.35 & 2.95 & 0.35 \\
$37.08 \mathrm{E}-4$ & 41.37 & 15.19 & 5.16 & 24.68 & 8.41 & 9.49 & 3.25 & 0.34 \\
& 68.95 & 17.33 & 5.04 & 25.1 & 7.74 & 7.77 & 2.7 & 0.35 \\
& 68.95 & 13.82 & 5.15 & 23.03 & 8.28 & 9.21 & 3.13 & 0.34 \\
& 96.53 & 16.65 & 5.04 & 24.41 & 7.9 & 7.76 & 2.86 & 0.37 \\
& 96.53 & 14.47 & 5.12 & 23.38 & 8.24 & 8.91 & 3.12 & 0.35 \\
\hline & 41.37 & 34.44 & 5.06 & 45.6 & 7 & 11.16 & 1.94 & 0.17 \\
& 41.37 & 33.42 & 5.03 & 45.98 & 6.99 & 12.56 & 1.96 & 0.16 \\
& 68.95 & 32.76 & 5.09 & 45.22 & 7.15 & 12.46 & 2.06 & 0.17 \\
& 68.95 & 16.54 & 4.94 & 27.76 & 6.81 & 11.22 & 1.87 & 0.17 \\
& 96.53 & 34.68 & 4.99 & 47.14 & 6.93 & 12.46 & 1.94 & 0.16 \\
& 96.53 & 31.58 & 4.99 & 43.46 & 6.81 & 11.88 & 1.82 & 0.15 \\
\hline \multirow{5}{*}{$9.48 \mathrm{E}-4$} & 41.37 & 73.29 & 4.95 & 90.43 & 6.05 & 17.14 & 1.1 & 0.06 \\
& 41.37 & 72.15 & 5.01 & 87.87 & 6.18 & 15.72 & 1.17 & 0.07 \\
& 68.95 & 75 & 5.02 & 97.12 & 6.47 & 22.12 & 1.45 & 0.07 \\
& 68.95 & 72.98 & 4.93 & 91.45 & 6.14 & 18.46 & 1.21 & 0.07 \\
& 96.53 & 71.39 & 4.94 & 88.6 & 6.21 & 17.22 & 1.27 & 0.07 \\
& 96.53 & 65.3 & 4.96 & 84.83 & 6.27 & 19.53 & 1.32 & 0.07 \\
\hline
\end{tabular}




\section{H. Full CCM Percolation Testing SUMMARY}




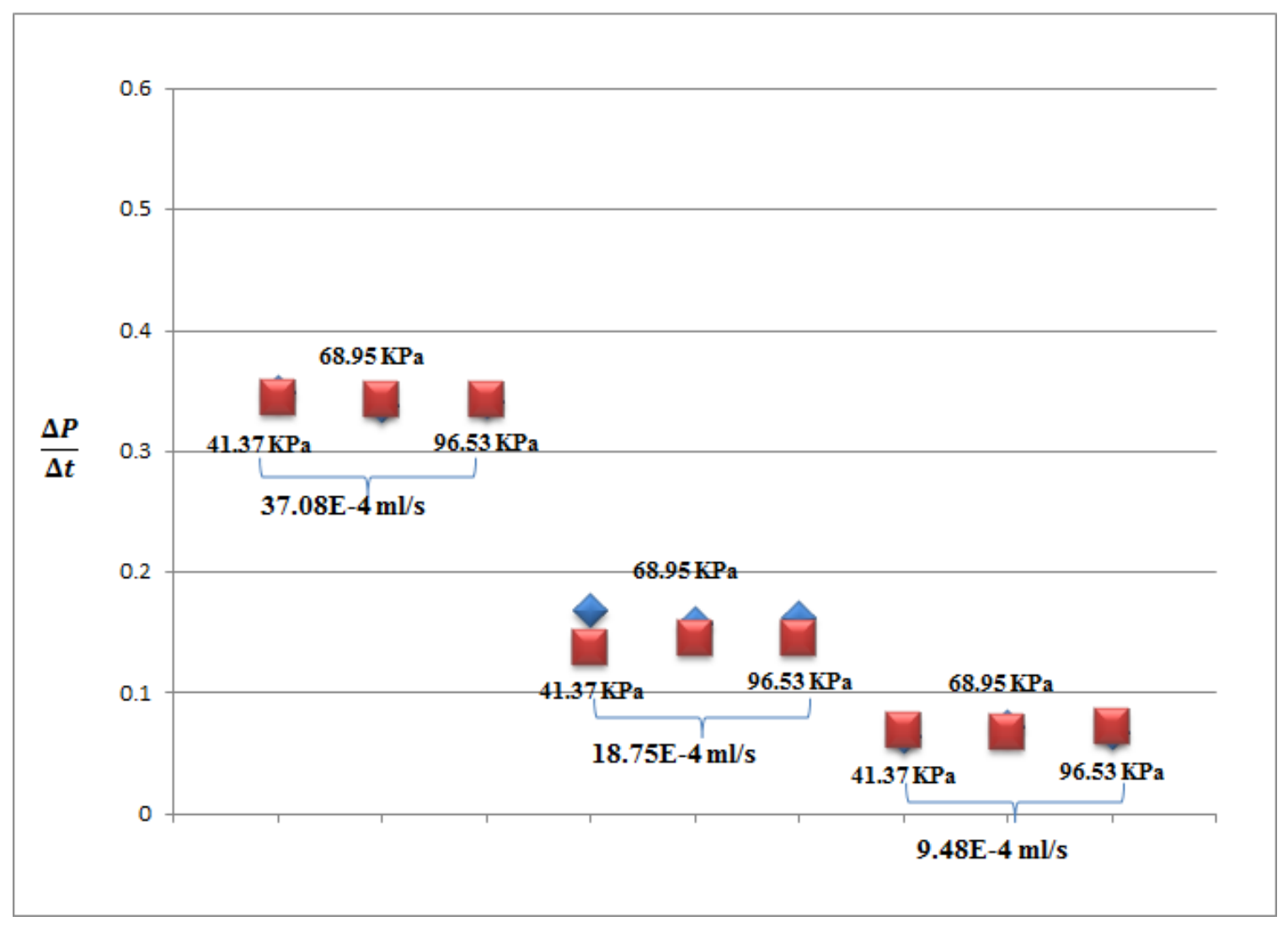

Figure H.1. Summary of percolation pressure growth rate on VD420. 


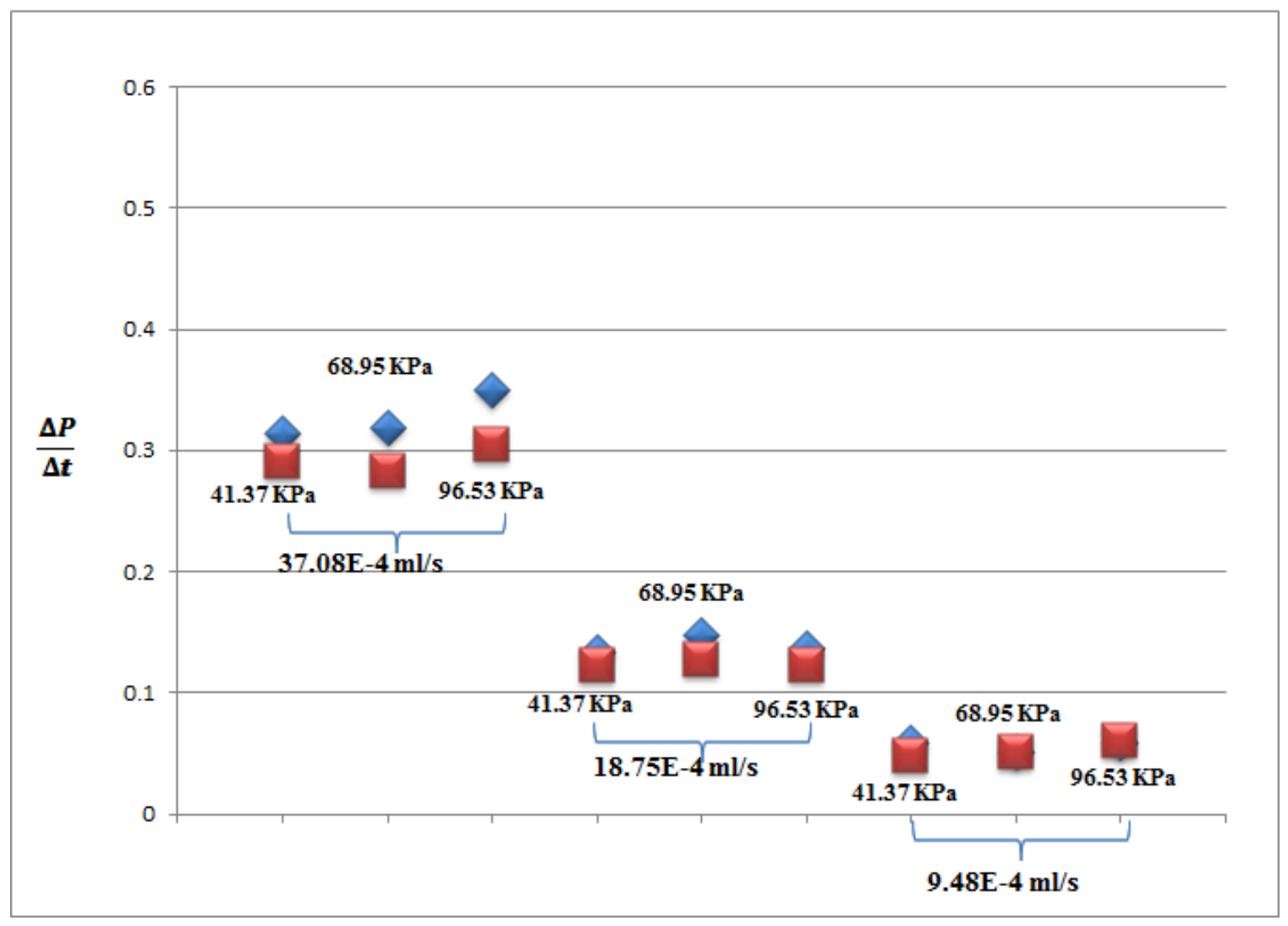

Figure H.2. Summary of percolation pressure growth rate on VD421. 


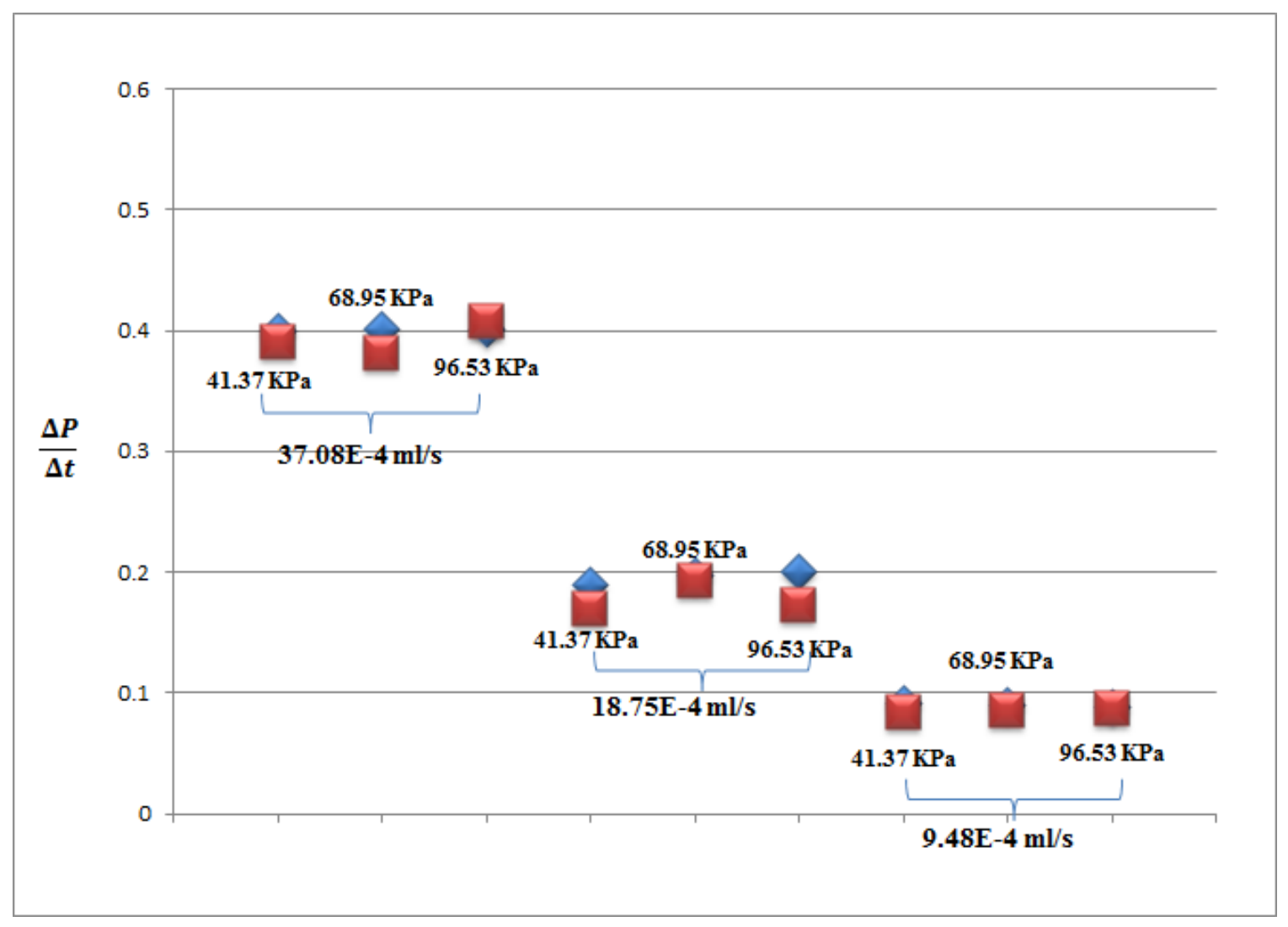

Figure H.3. Summary of percolation pressure growth rate on VD423. 


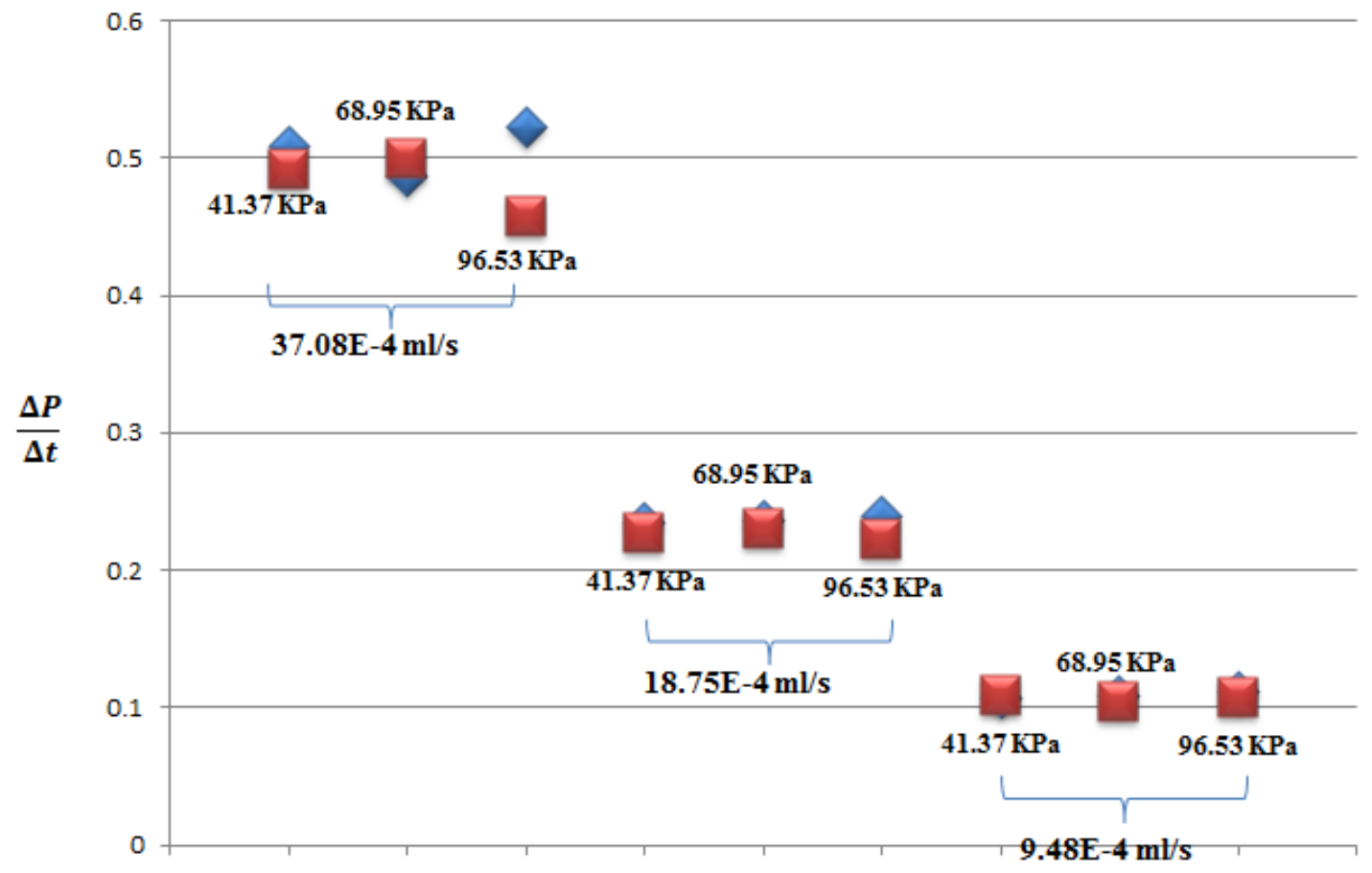

Figure H.4. Summary of percolation pressure growth rate on VD422. 


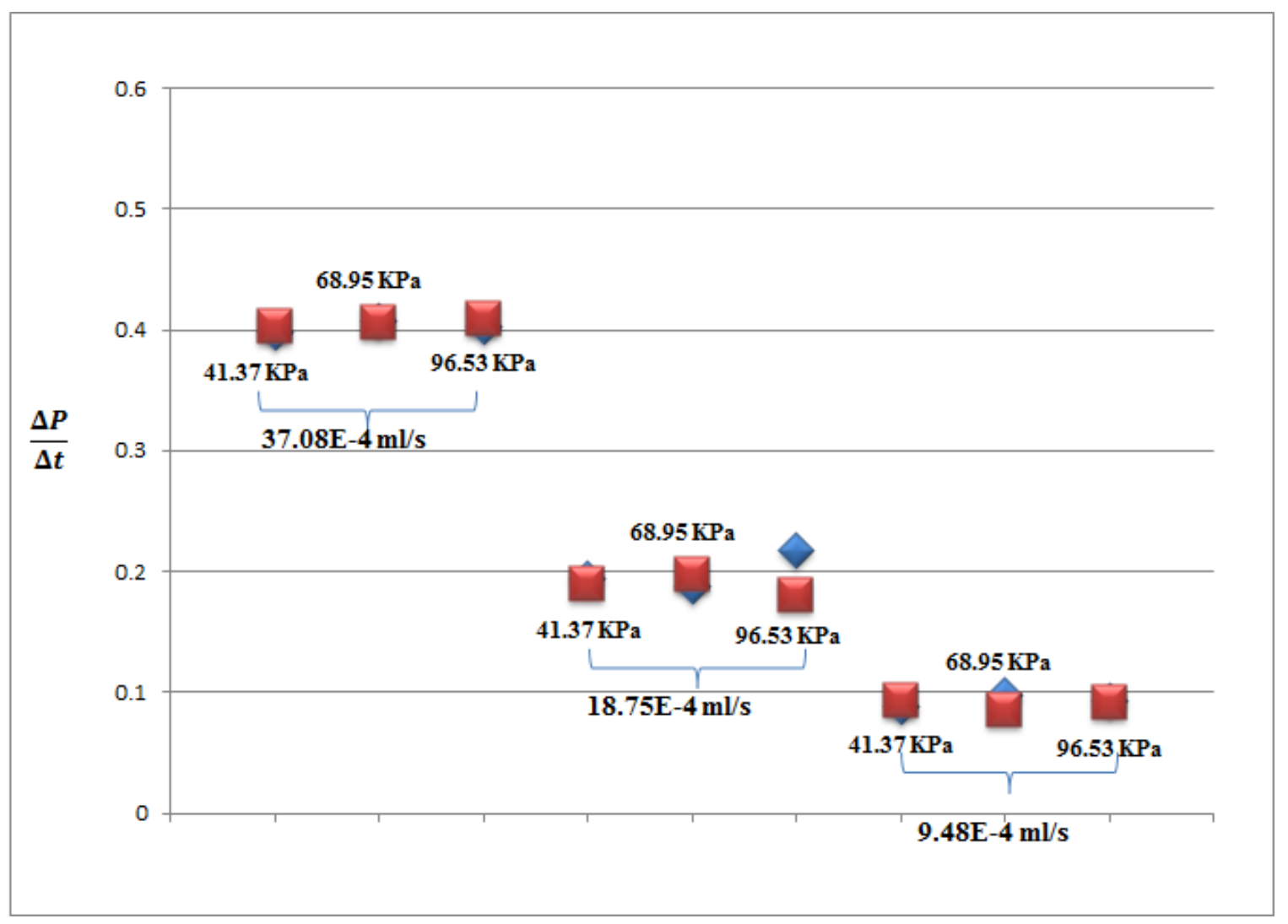

Figure H.5. Summary of percolation pressure growth rate on VD424. 


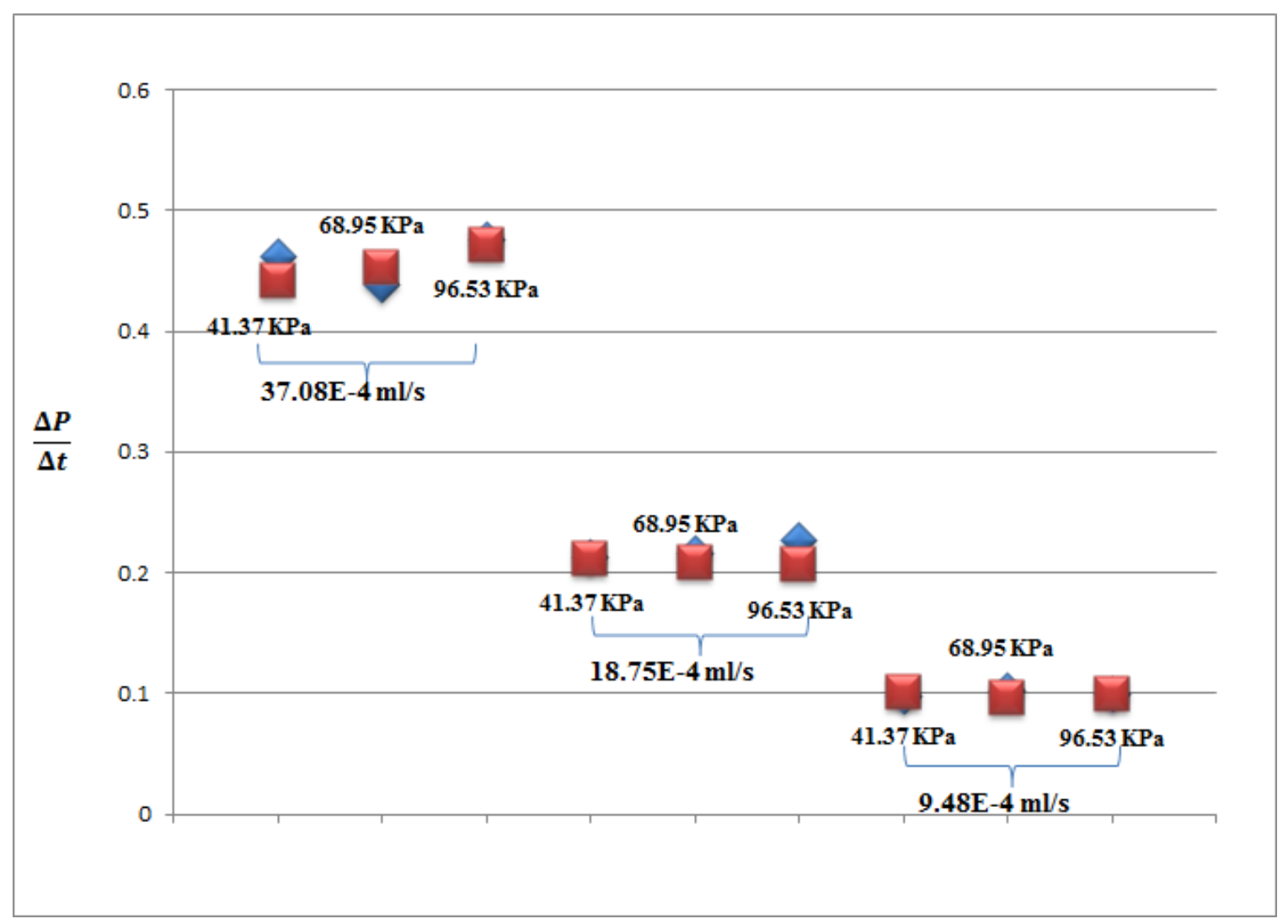

Figure H.6. Summary of percolation pressure growth rate on VD425. 


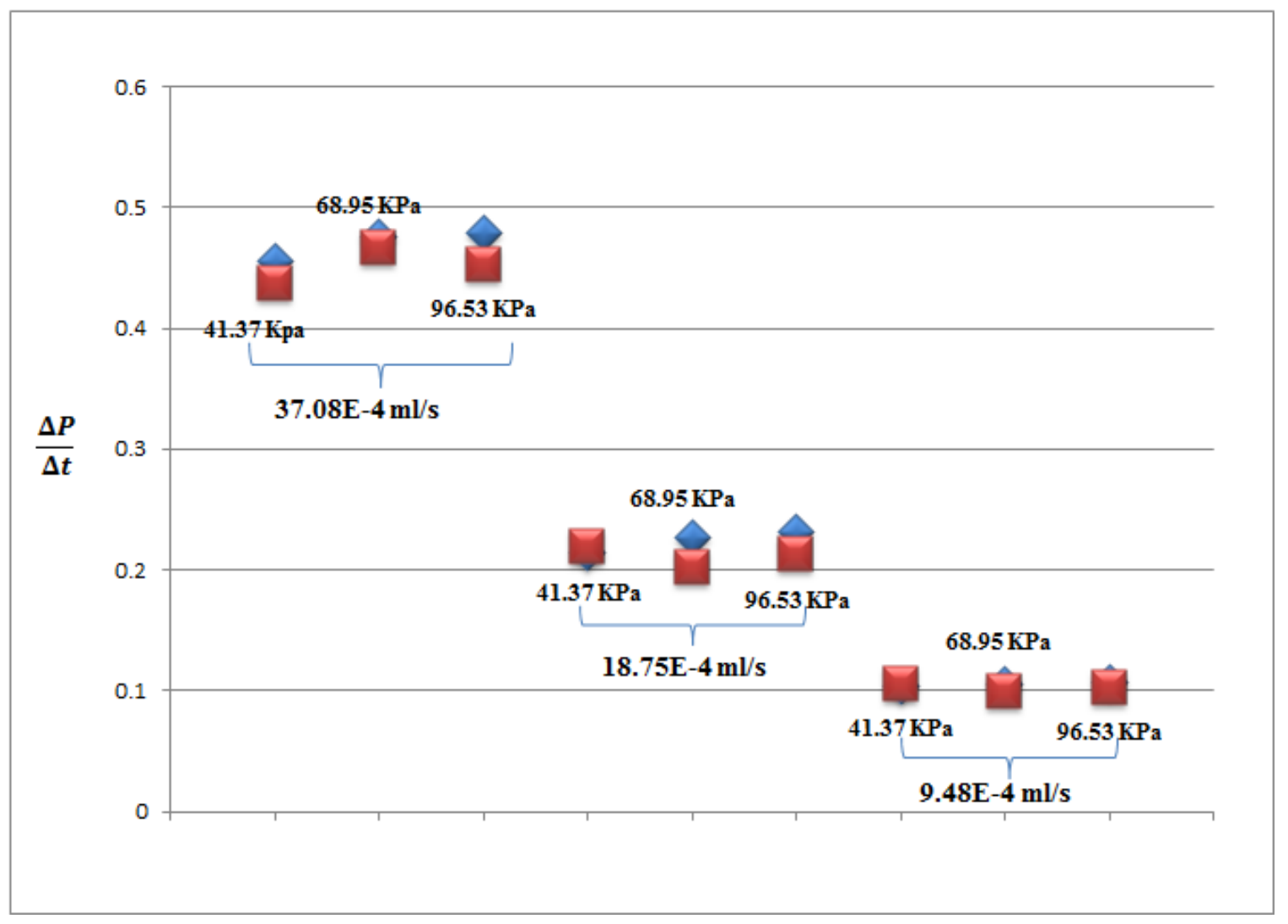

Figure H.7. Summary of percolation pressure growth rate on VD432. 


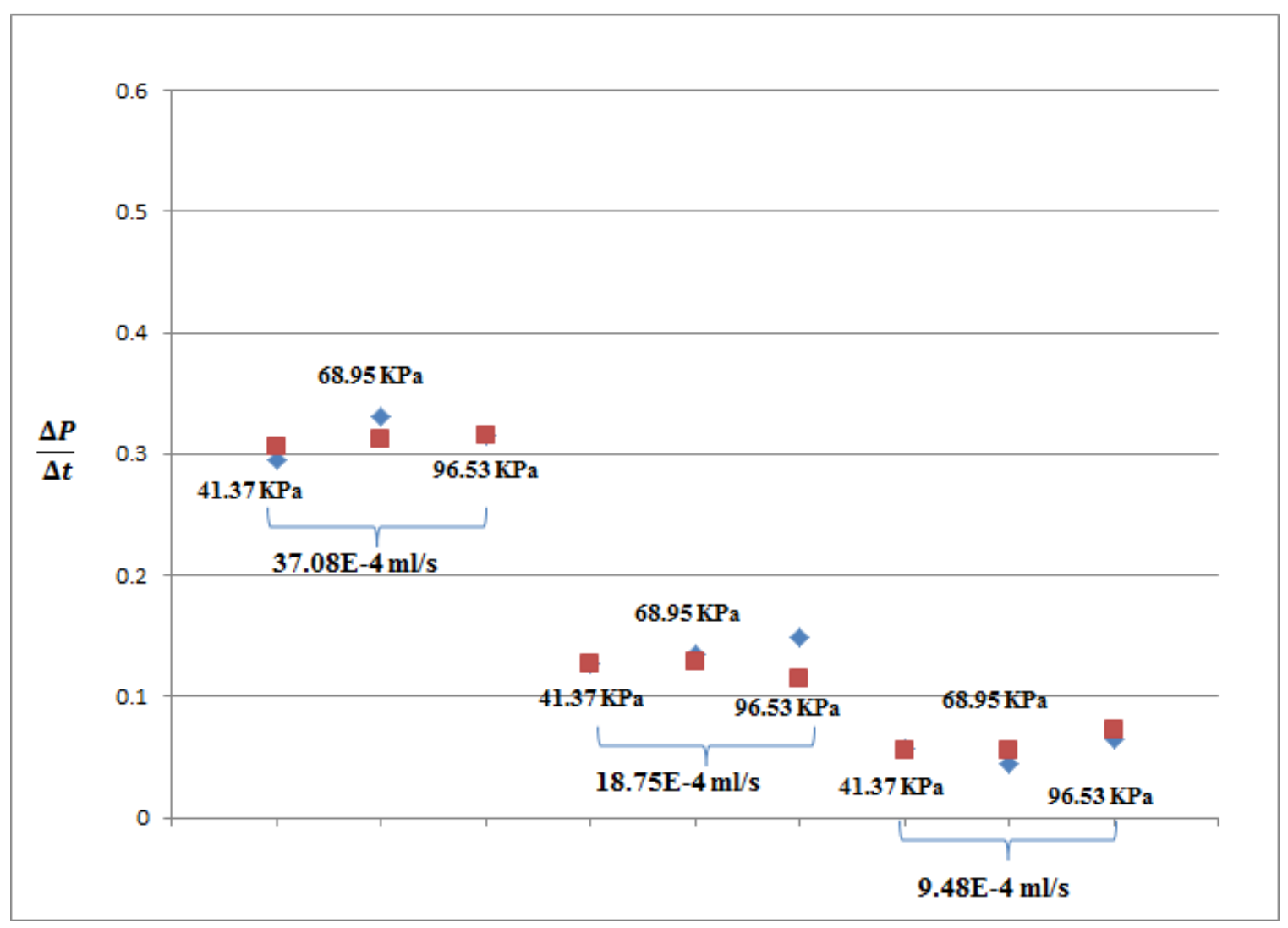

Figure H.8. Summary of percolation pressure growth rate on VD436. 


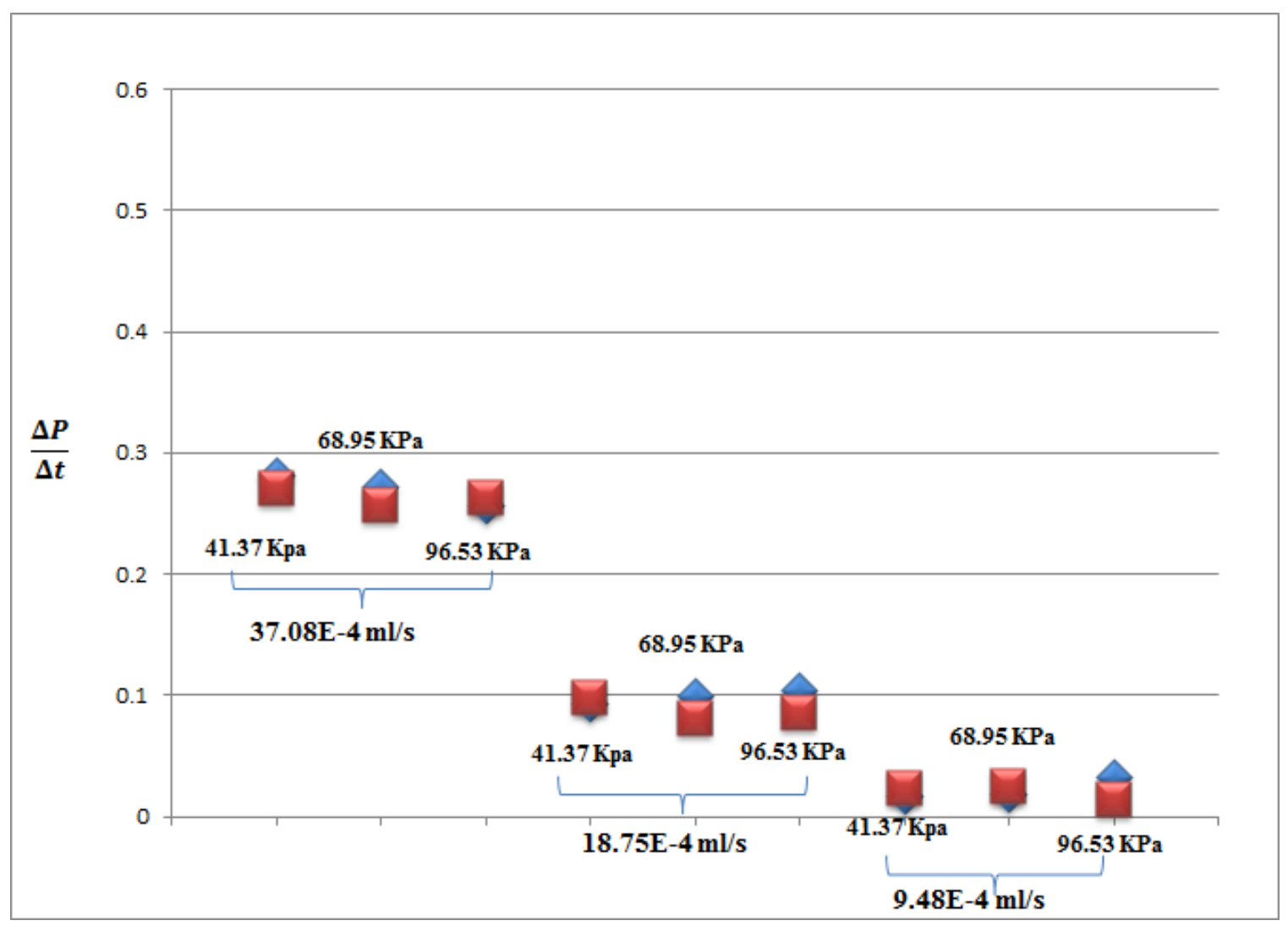

Figure H.9. Summary of percolation pressure growth rate on VD328. 


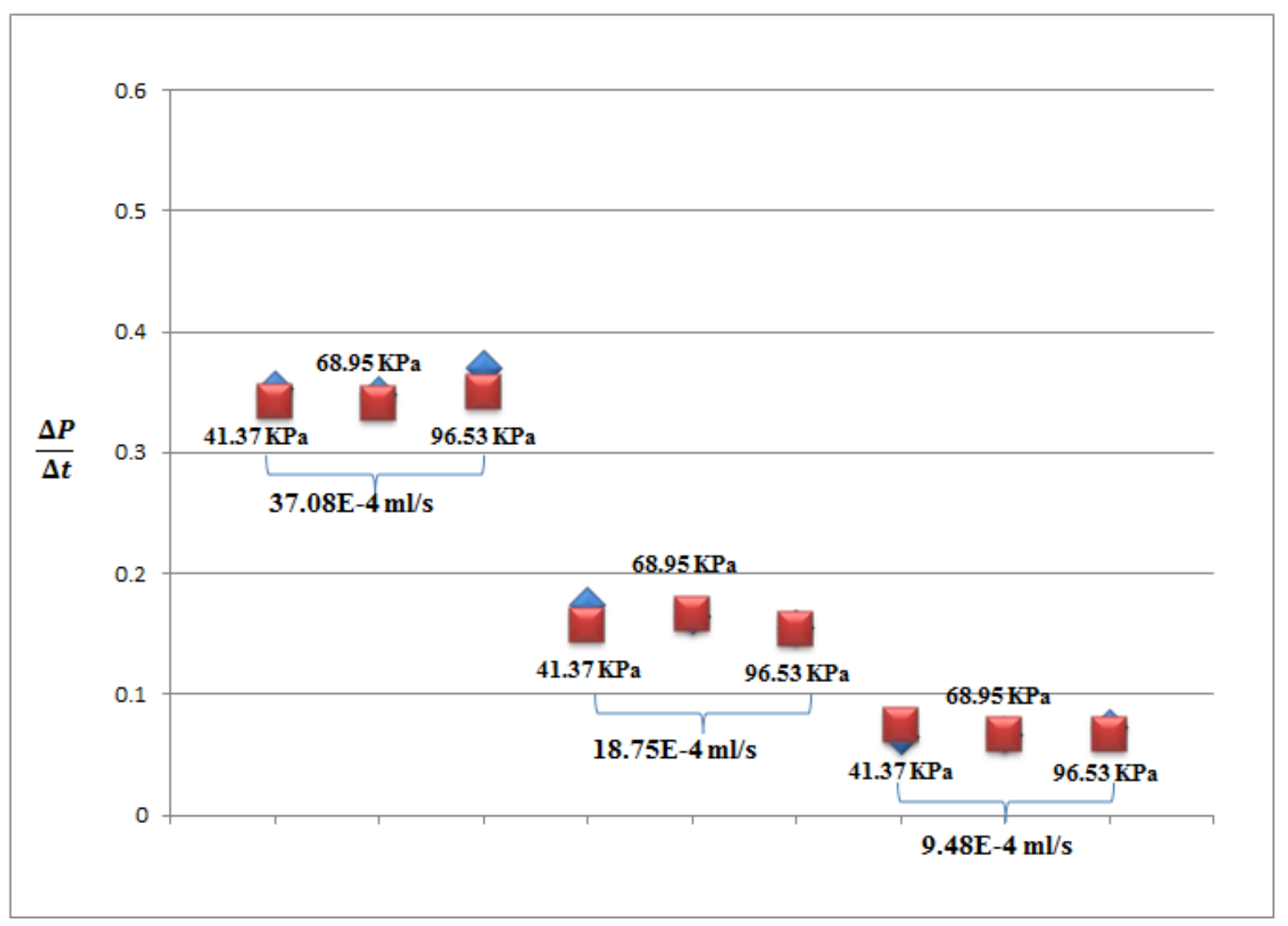

Figure H.10. Summary of percolation pressure growth rate on VD302. 


\section{Full CCM Pressure vs Wetted VOLUME}




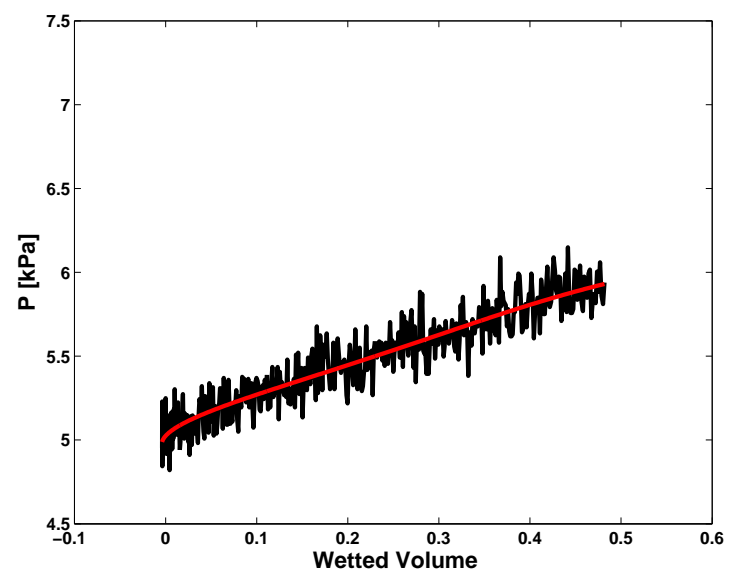

(a) Test at $41.37 \mathrm{kPa}$.

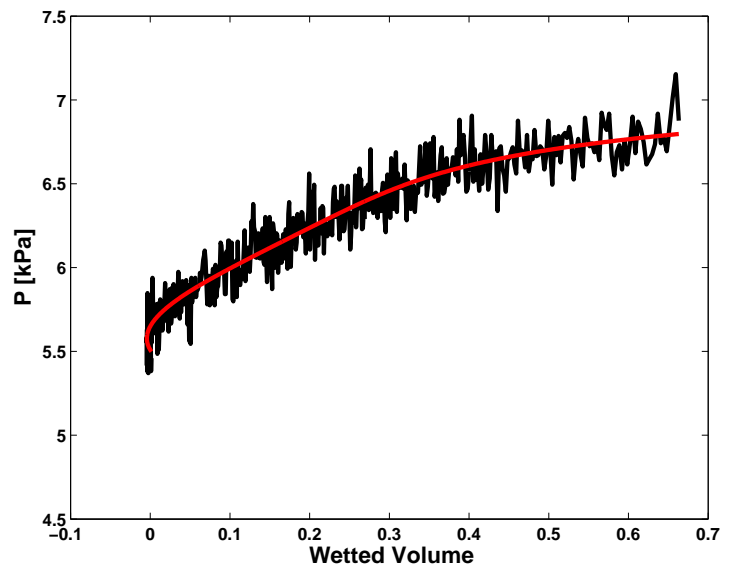

(b) $1^{\text {st }}$ test at $68.95 \mathrm{kPa}$.

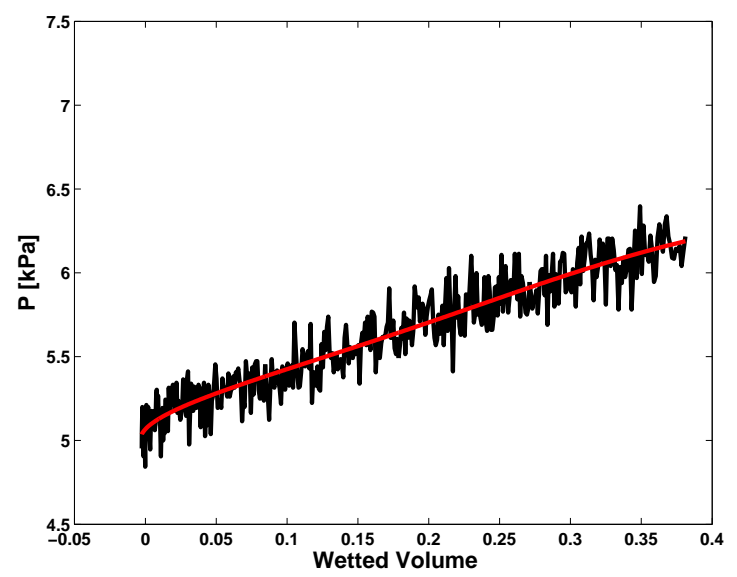

(c) $1^{\text {st }}$ test at $96.53 \mathrm{kPa}$.

Figure I.1. Percolation pressure vs wetted volume for VD420. The tests were conducted at three different compressions on the sample $41.37 \mathrm{kPa}, 68.95 \mathrm{kPa}$, $96.53 \mathrm{kPa}$ while holding the flow rate constant at $9.48 \mathrm{E}-4 \mathrm{mLs}^{-1}$. 


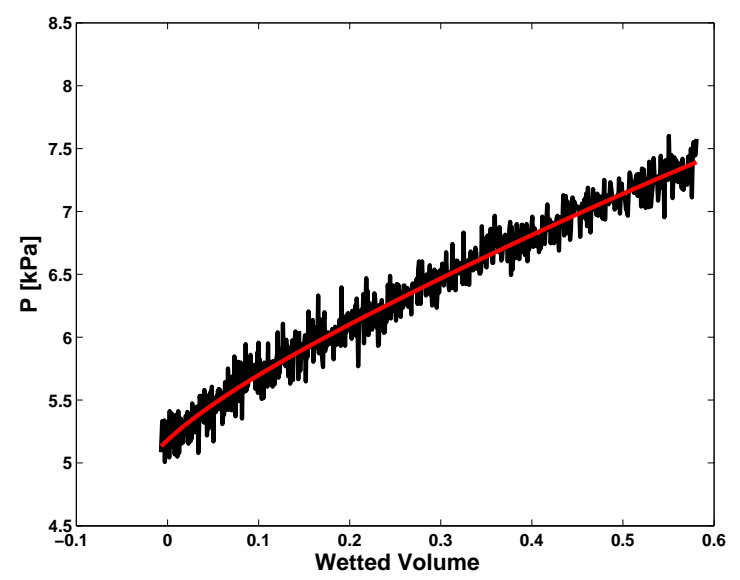

(a) $1^{\text {st }}$ test at $41.37 \mathrm{kPa}$.

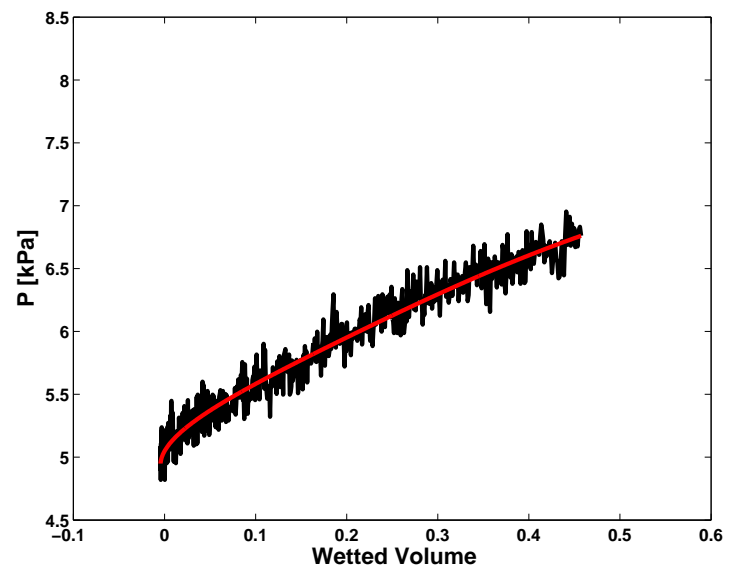

(c) $1^{\text {st }}$ test at $68.95 \mathrm{kPa}$.

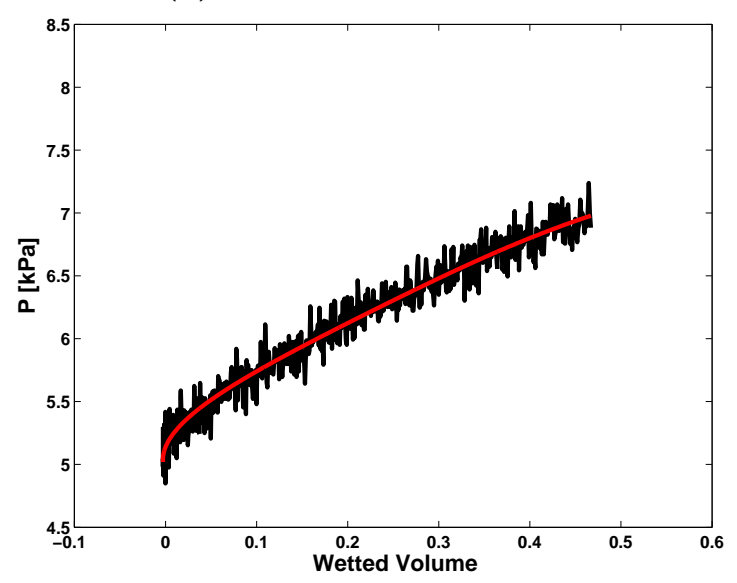

(e) $1^{\text {st }}$ test at $96.53 \mathrm{kPa}$.

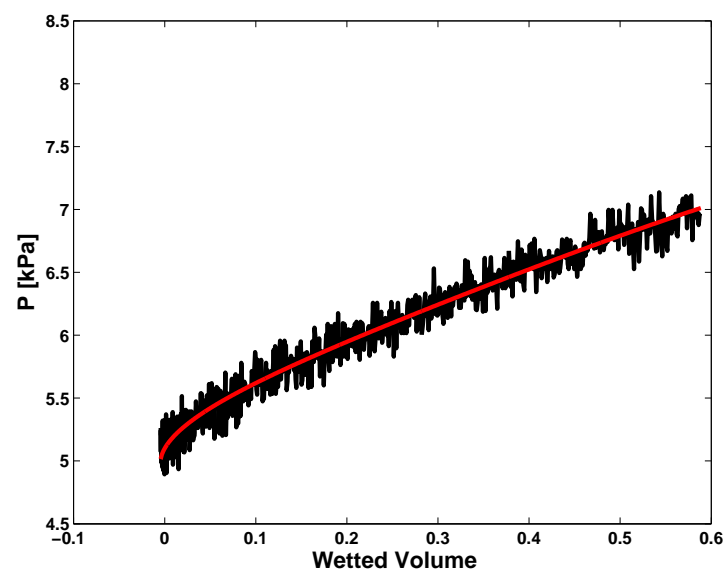

(b) $1^{\text {st }}$ test at $41.37 \mathrm{kPa}$.

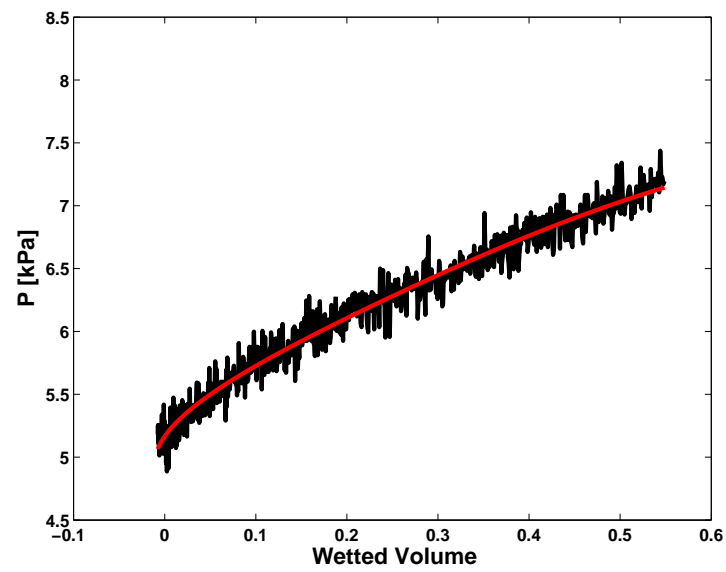

(d) $2^{\text {nd }}$ test at $68.95 \mathrm{kPa}$.

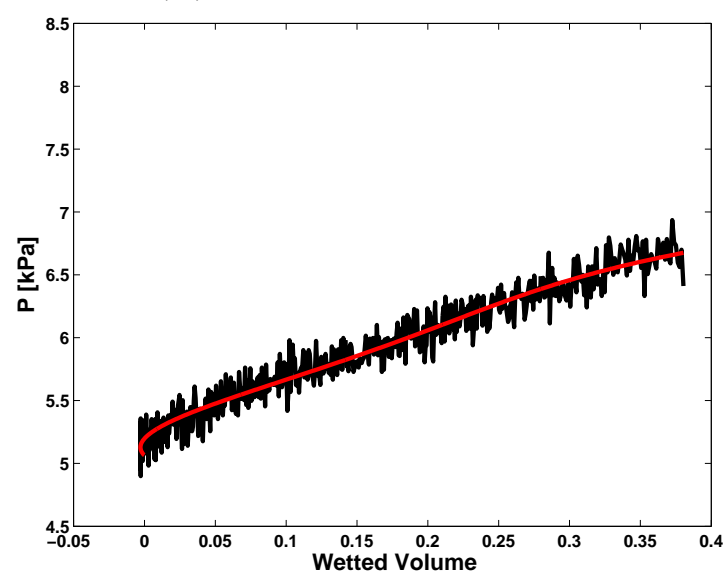

(f) $2^{\text {nd }}$ test at $96.53 \mathrm{kPa}$.

Figure I.2. Percolation pressure vs wetted volume for VD420. The tests were conducted at three different compressions on the sample $41.37 \mathrm{kPa}, 68.95 \mathrm{kPa}$, $96.53 \mathrm{kPa}$ while holding the flow rate constant at $18.75 \mathrm{E}-4 \mathrm{mLs}^{-1}$. 


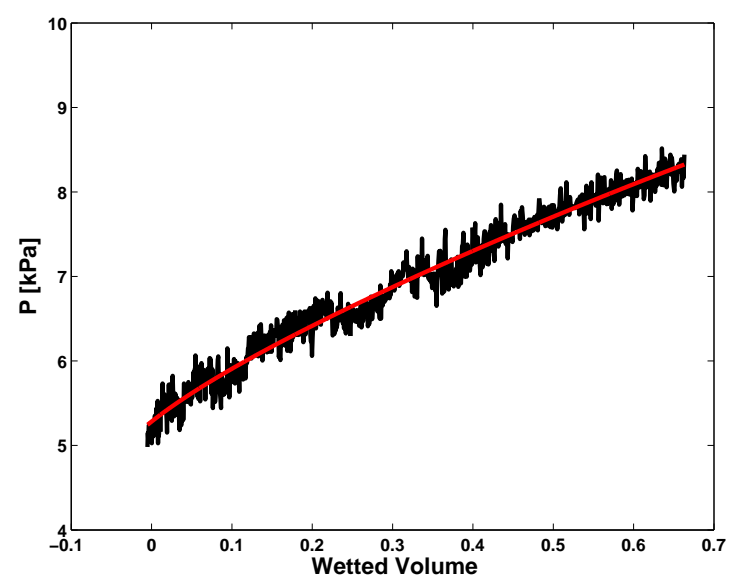

(a) $1^{\text {st }}$ test at $41.37 \mathrm{kPa}$.

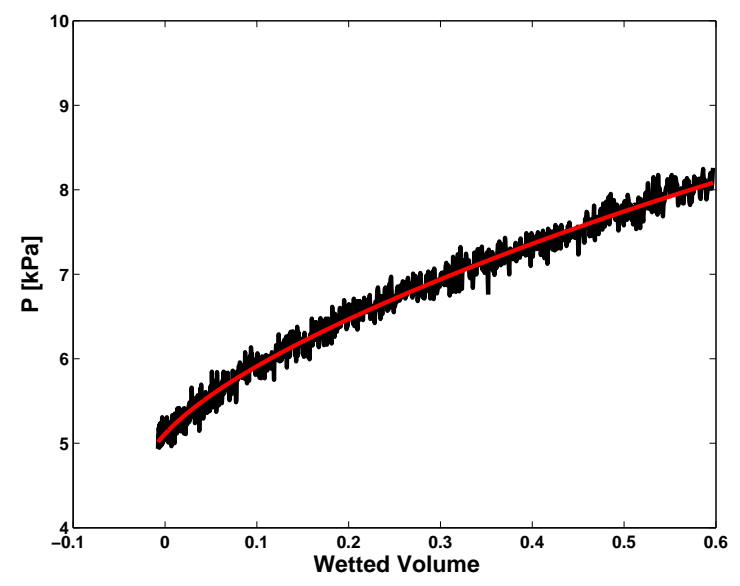

(c) $1^{\text {st }}$ test at $68.95 \mathrm{kPa}$.

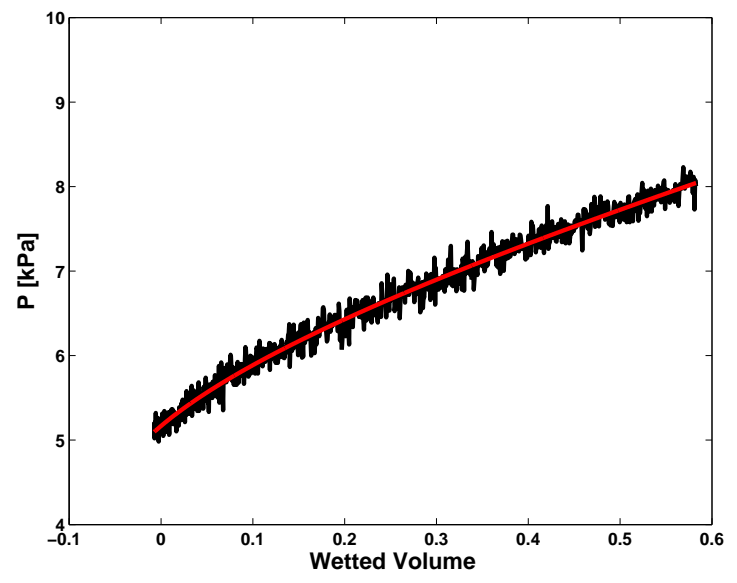

(e) $1^{\text {st }}$ test at $96.53 \mathrm{kPa}$.

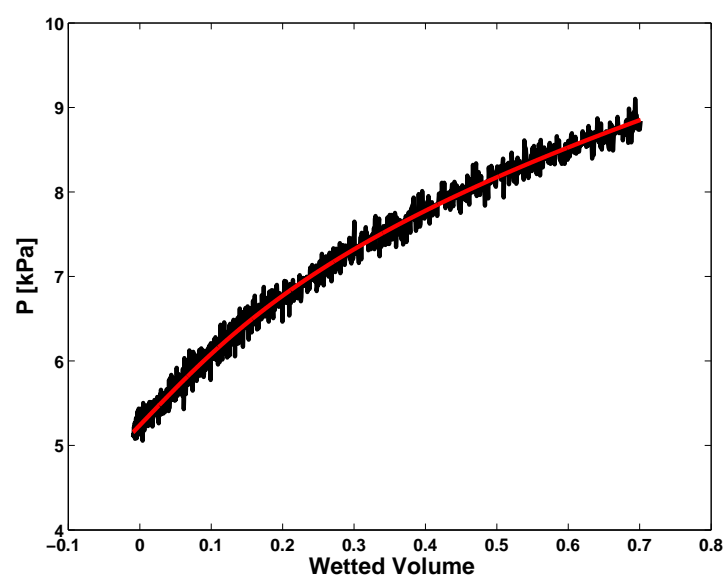

(b) $1^{\text {st }}$ test at $41.37 \mathrm{kPa}$.

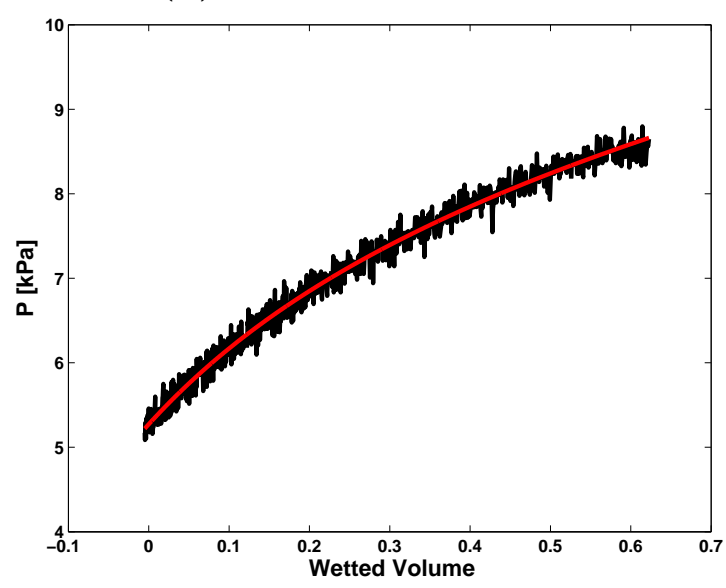

(d) $2^{\text {nd }}$ test at $68.95 \mathrm{kPa}$.

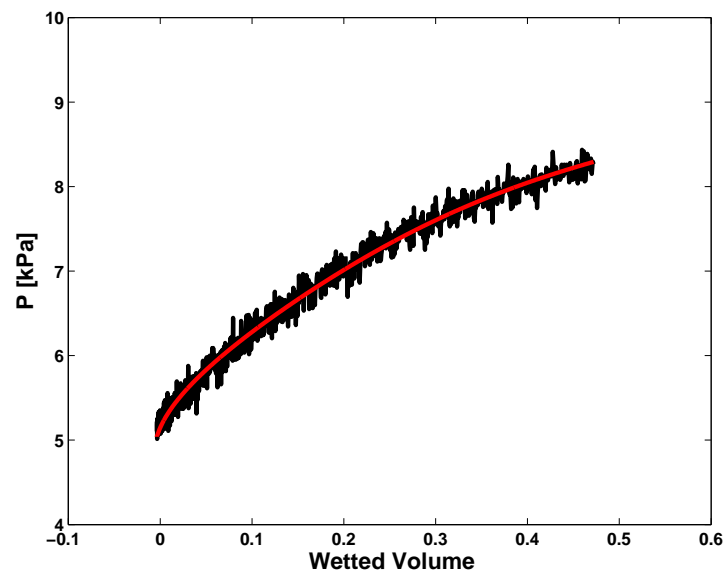

(f) $2^{\text {nd }}$ test at $96.53 \mathrm{kPa}$.

Figure I.3. Percolation pressure vs wetted volume for VD420. The tests were conducted at three different compressions on the sample $41.37 \mathrm{kPa}, 68.95 \mathrm{kPa}$, $96.53 \mathrm{kPa}$ while holding the flow rate constant at $37.08 \mathrm{E}-4 \mathrm{mLs}^{-1}$. 


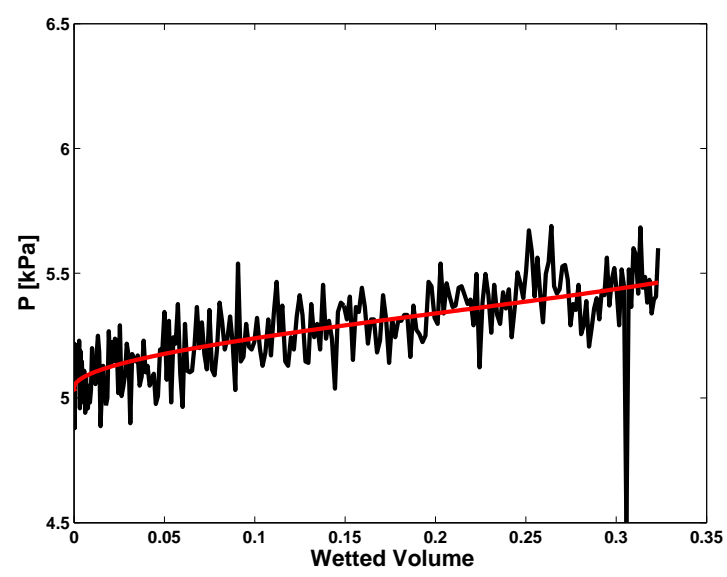

(a) Test at $41.37 \mathrm{kPa}$.

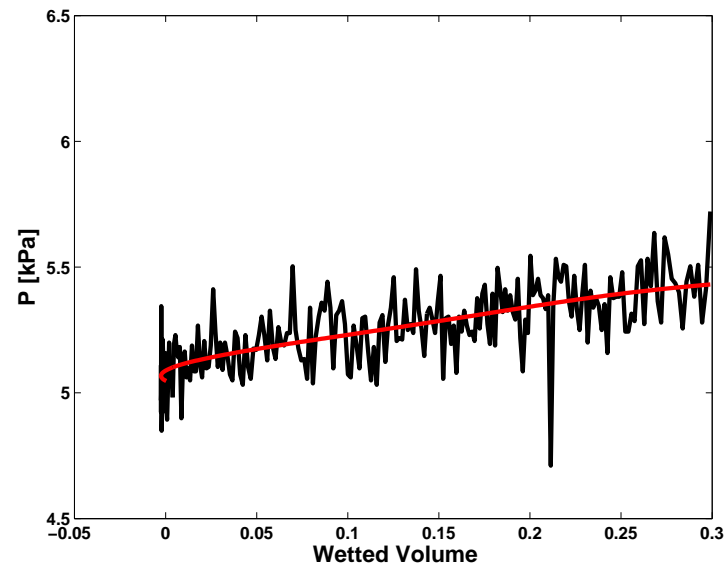

(b) $1^{\text {st }}$ test at $68.95 \mathrm{kPa}$.

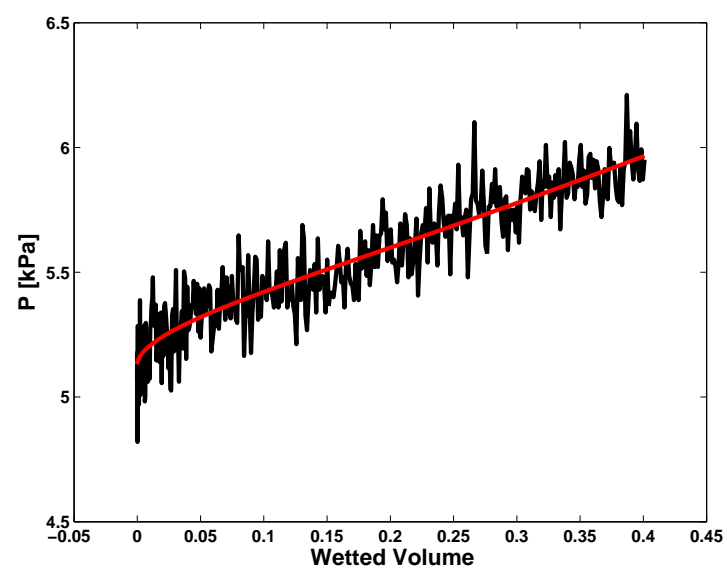

(c) $1^{\text {st }}$ test at $96.53 \mathrm{kPa}$.

Figure I.4. Percolation pressure vs wetted volume for VD421. The tests were conducted at three different compressions on the sample $41.37 \mathrm{kPa}, 68.95 \mathrm{kPa}$, $96.53 \mathrm{kPa}$ while holding the flow rate constant at $9.48 \mathrm{E}-4 \mathrm{mLs}^{-1}$. 


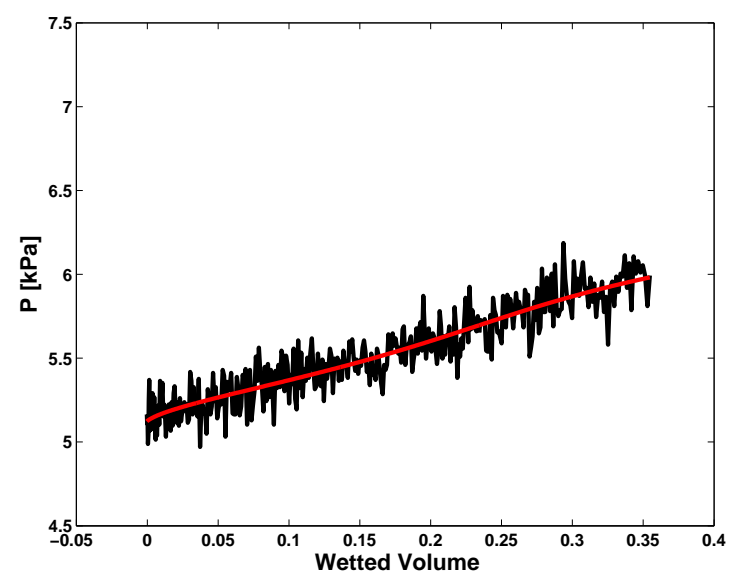

(a) $1^{\text {st }}$ test at $41.37 \mathrm{kPa}$.

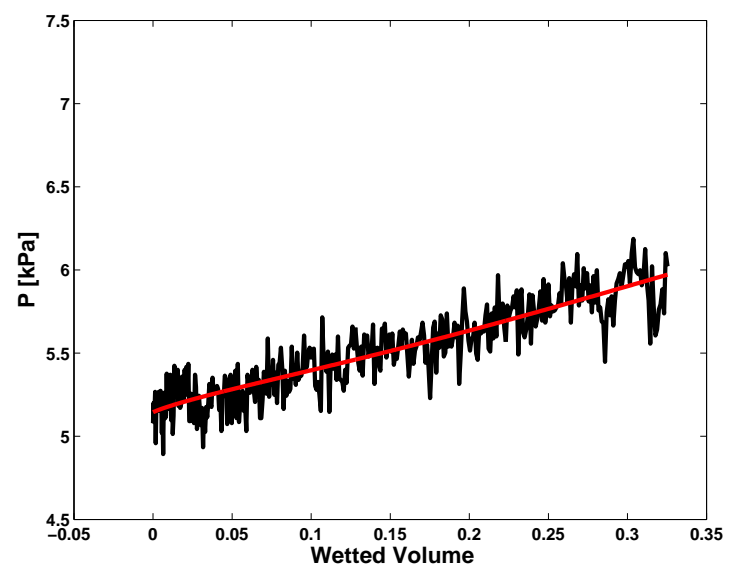

(c) $1^{\text {st }}$ test at $68.95 \mathrm{kPa}$.

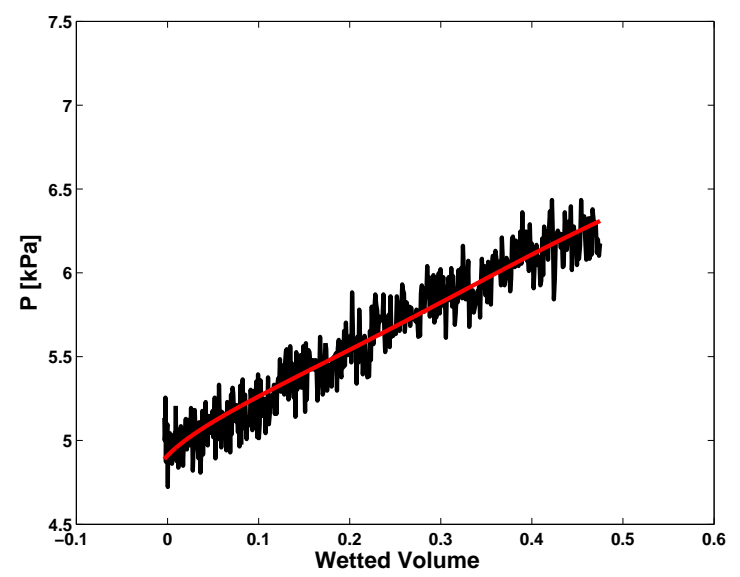

(e) $1^{\text {st }}$ test at $96.53 \mathrm{kPa}$.

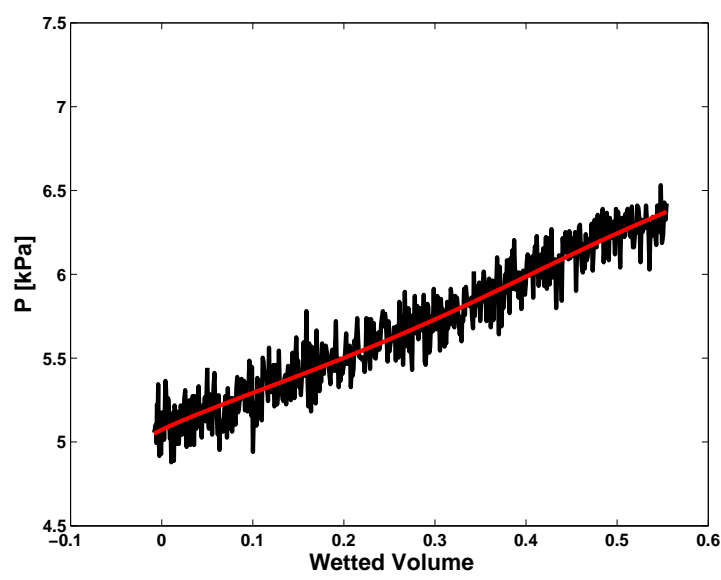

(b) $1^{\text {st }}$ test at $41.37 \mathrm{kPa}$.

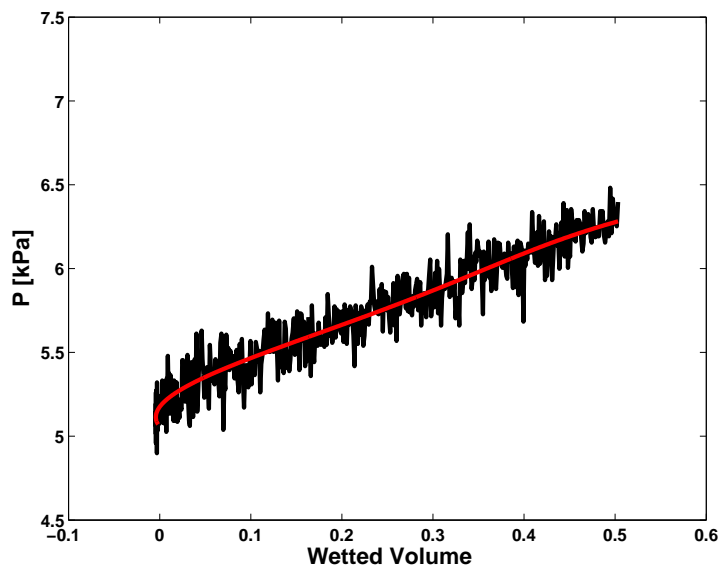

(d) $2^{\text {nd }}$ test at $68.95 \mathrm{kPa}$.

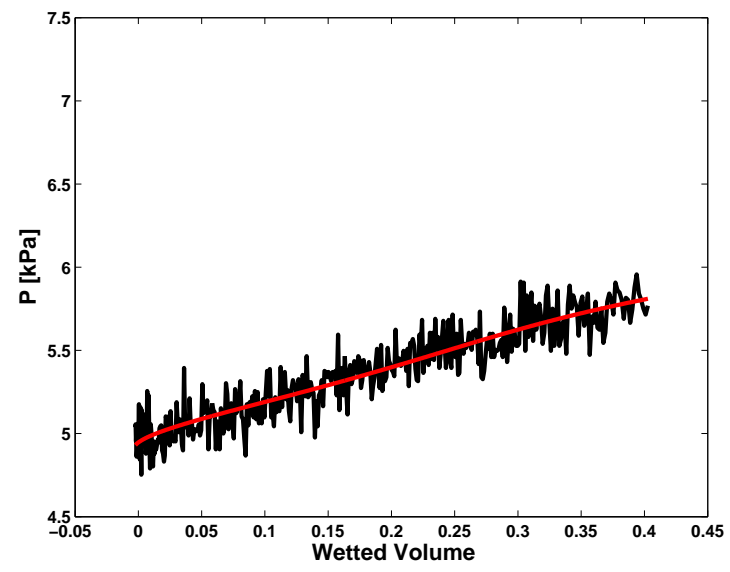

(f) $2^{\text {nd }}$ test at $96.53 \mathrm{kPa}$.

Figure I.5. Percolation pressure vs wetted volume for VD421. The tests were conducted at three different compressions on the sample $41.37 \mathrm{kPa}, 68.95 \mathrm{kPa}$, $96.53 \mathrm{kPa}$ while holding the flow rate constant at $18.75 \mathrm{E}-4 \mathrm{mLs}^{-1}$. 


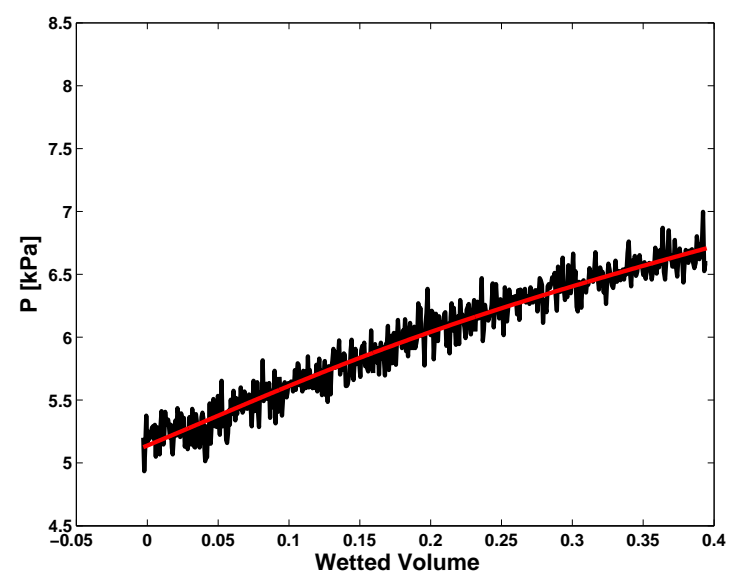

(a) $1^{\text {st }}$ test at $41.37 \mathrm{kPa}$.

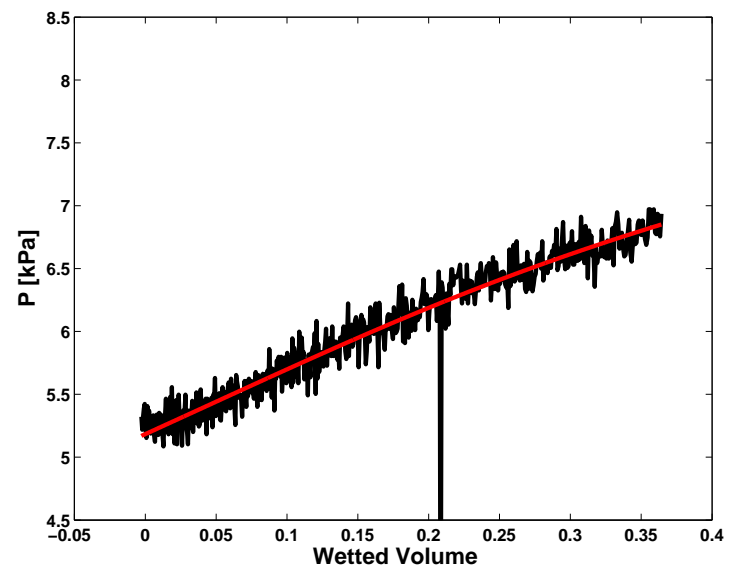

(c) $1^{\text {st }}$ test at $68.95 \mathrm{kPa}$.

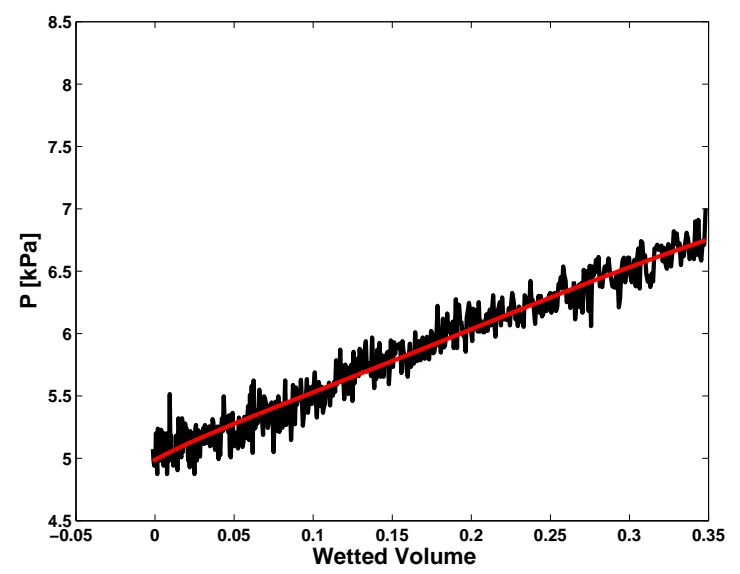

(e) $1^{\text {st }}$ test at $96.53 \mathrm{kPa}$.

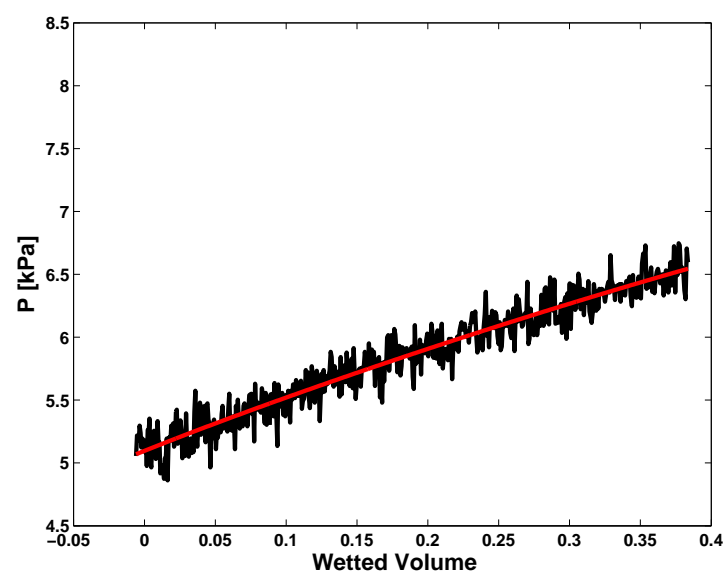

(b) $1^{\text {st }}$ test at $41.37 \mathrm{kPa}$.

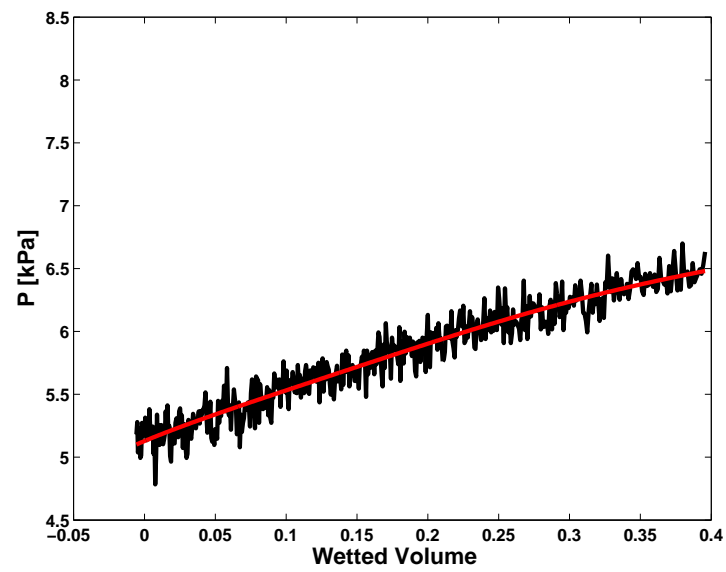

(d) $2^{\text {nd }}$ test at $68.95 \mathrm{kPa}$.

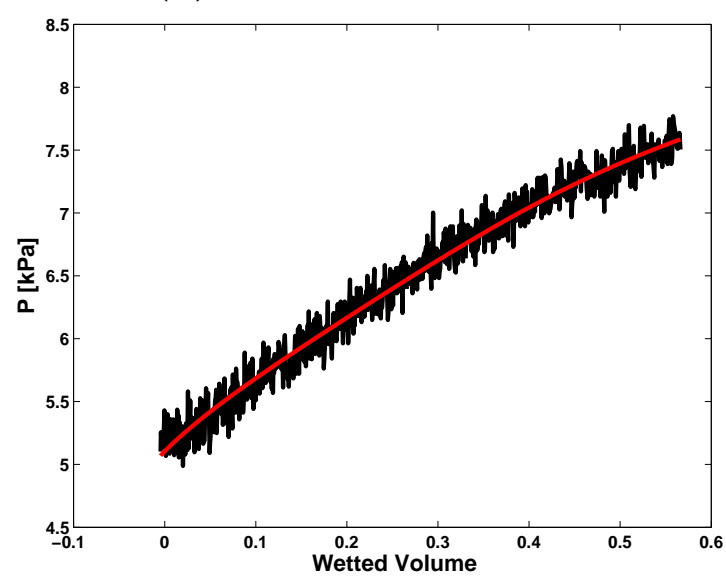

(f) $2^{\text {nd }}$ test at $96.53 \mathrm{kPa}$.

Figure I.6. Percolation pressure vs wetted volume for VD421. The tests were conducted at three different compressions on the sample $41.37 \mathrm{kPa}, 68.95 \mathrm{kPa}$, $96.53 \mathrm{kPa}$ while holding the flow rate constant at $37.08 \mathrm{E}-4 \mathrm{mLs}^{-1}$. 


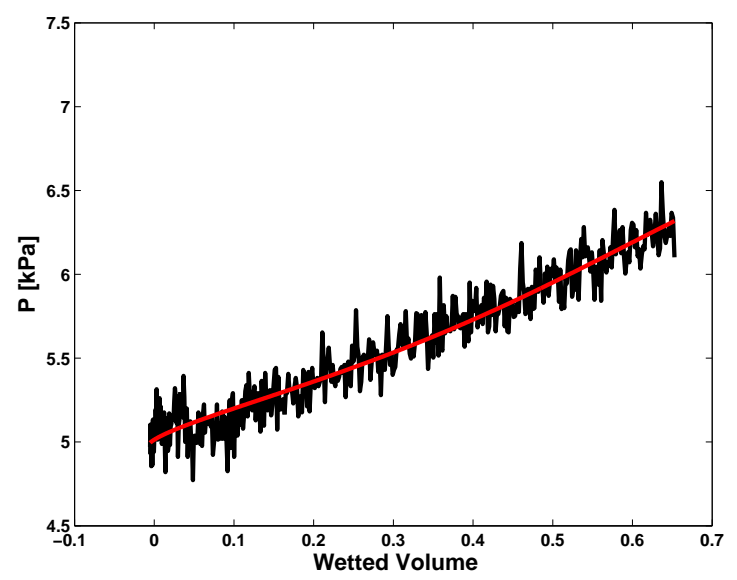

(a) Test at $41.37 \mathrm{kPa}$.

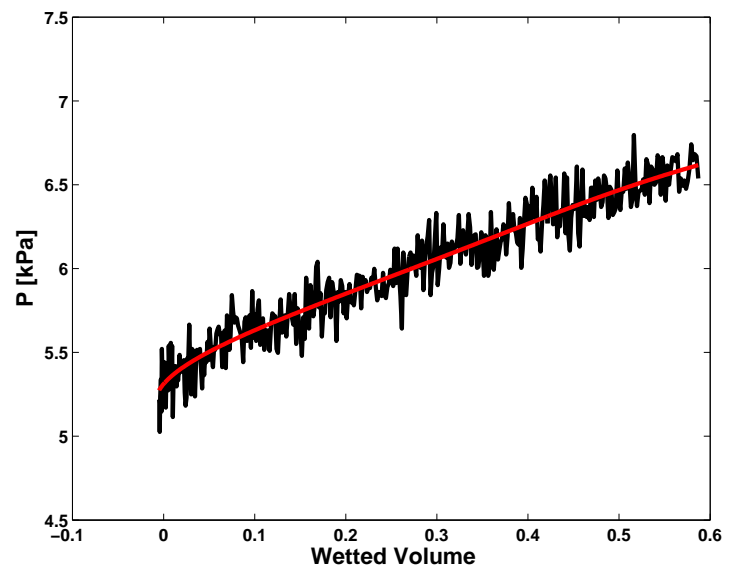

(b) $1^{\text {st }}$ test at $68.95 \mathrm{kPa}$.

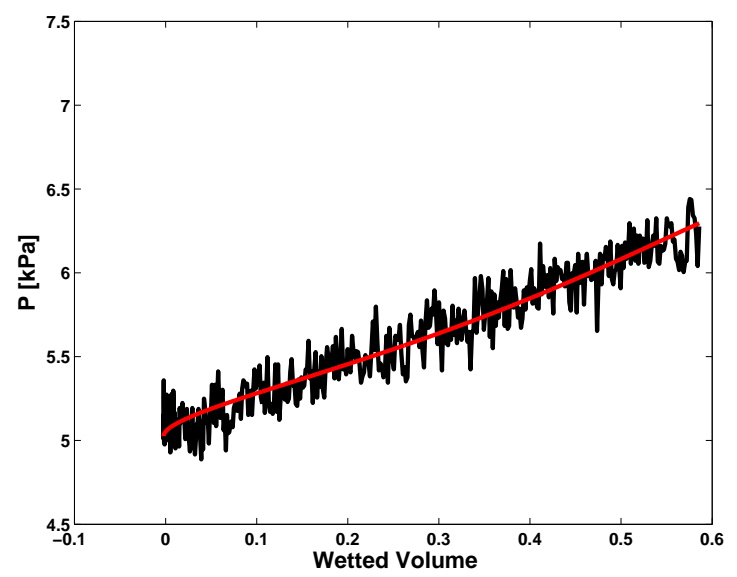

(c) $1^{\text {st }}$ test at $96.53 \mathrm{kPa}$.

Figure I.7. Percolation pressure vs wetted volume for VD423. The tests were conducted at three different compressions on the sample $41.37 \mathrm{kPa}, 68.95 \mathrm{kPa}$, $96.53 \mathrm{kPa}$ while holding the flow rate constant at $9.48 \mathrm{E}-4 \mathrm{mLs}^{-1}$. 


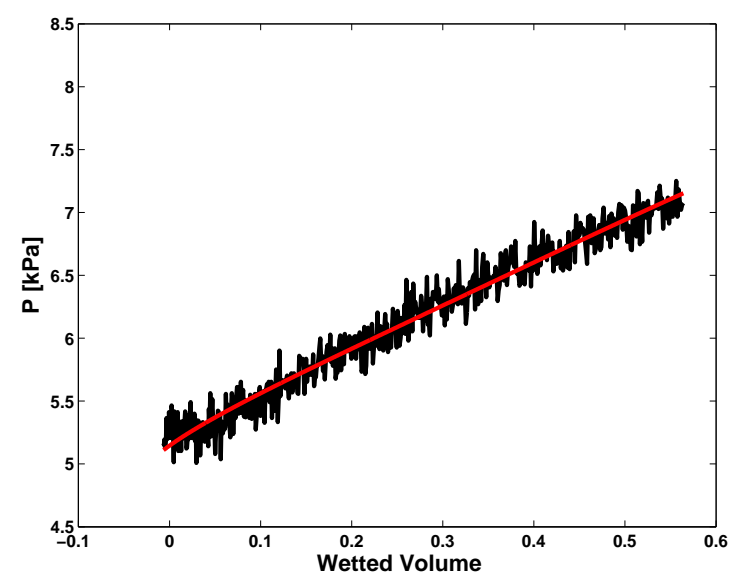

(a) $1^{\text {st }}$ test at $41.37 \mathrm{kPa}$.

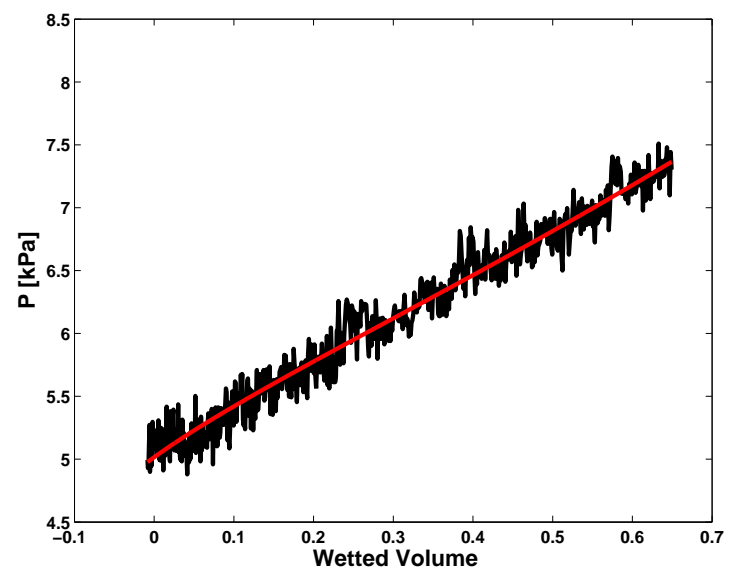

(c) $1^{\text {st }}$ test at $68.95 \mathrm{kPa}$.

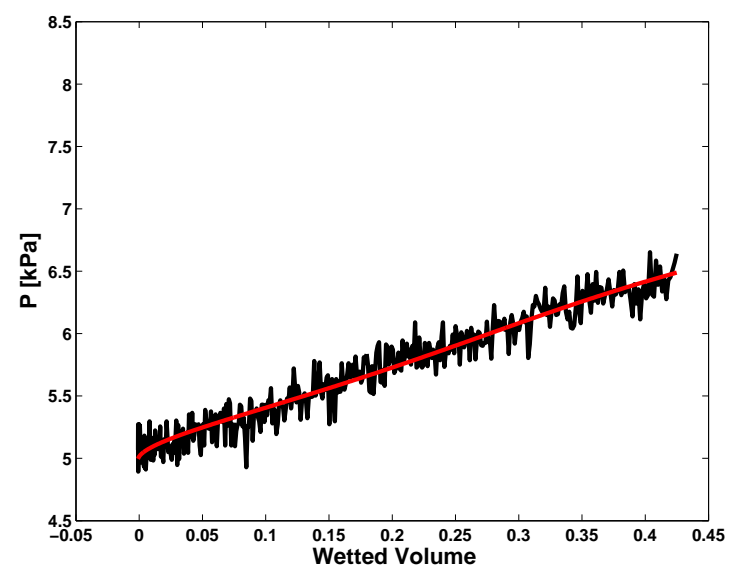

(e) $1^{\text {st }}$ test at $96.53 \mathrm{kPa}$.

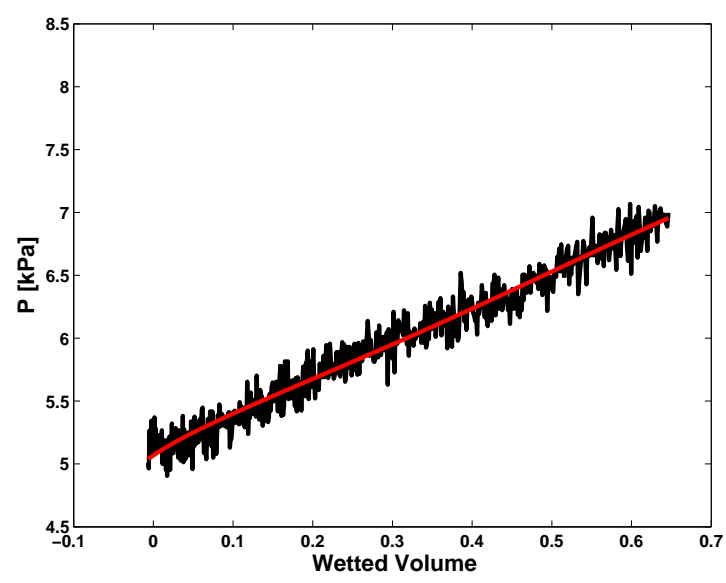

(b) $1^{\text {st }}$ test at $41.37 \mathrm{kPa}$.

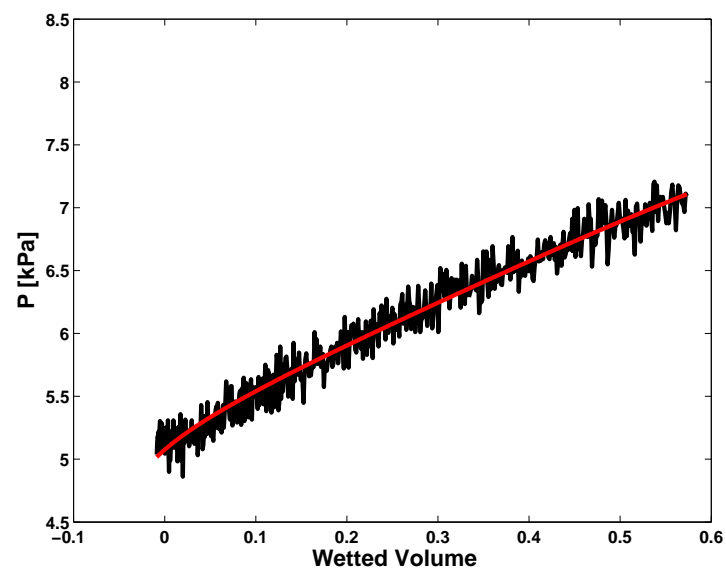

(d) $2^{\text {nd }}$ test at $68.95 \mathrm{kPa}$.

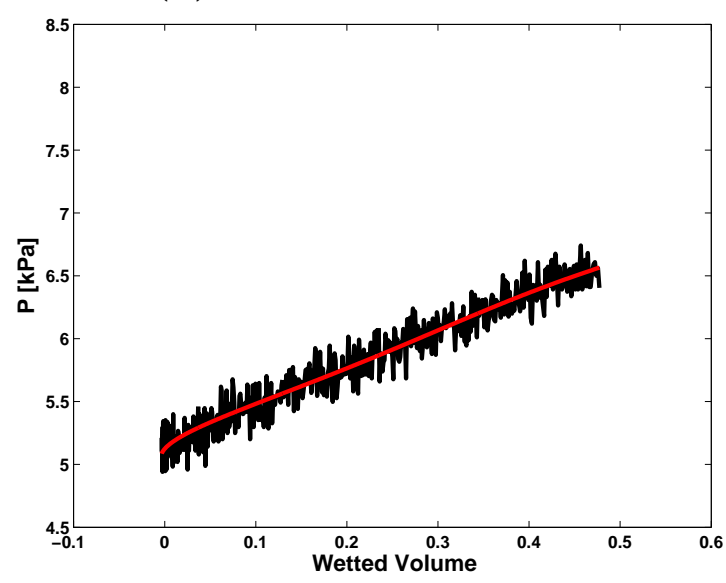

(f) $2^{\text {nd }}$ test at $96.53 \mathrm{kPa}$.

Figure I.8. Percolation pressure vs wetted volume for VD423. The tests were conducted at three different compressions on the sample $41.37 \mathrm{kPa}, 68.95 \mathrm{kPa}$, $96.53 \mathrm{kPa}$ while holding the flow rate constant at $18.75 \mathrm{E}-4 \mathrm{mLs}^{-1}$. 


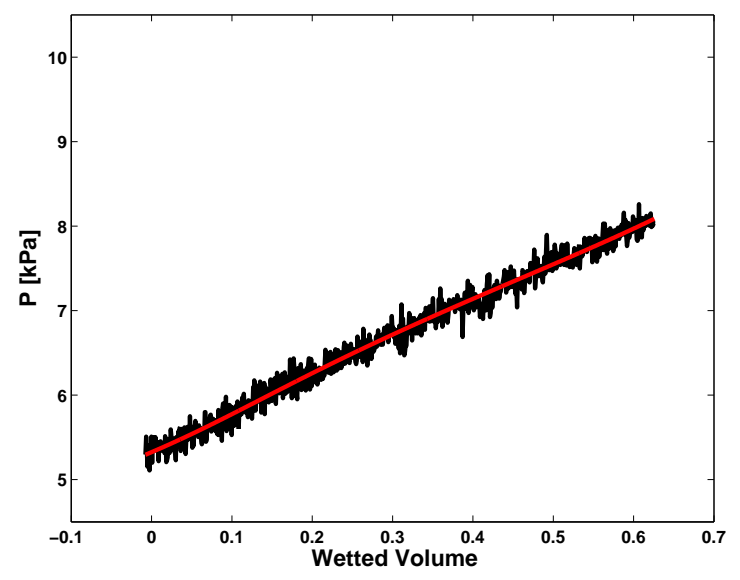

(a) $1^{\text {st }}$ test at $41.37 \mathrm{kPa}$.

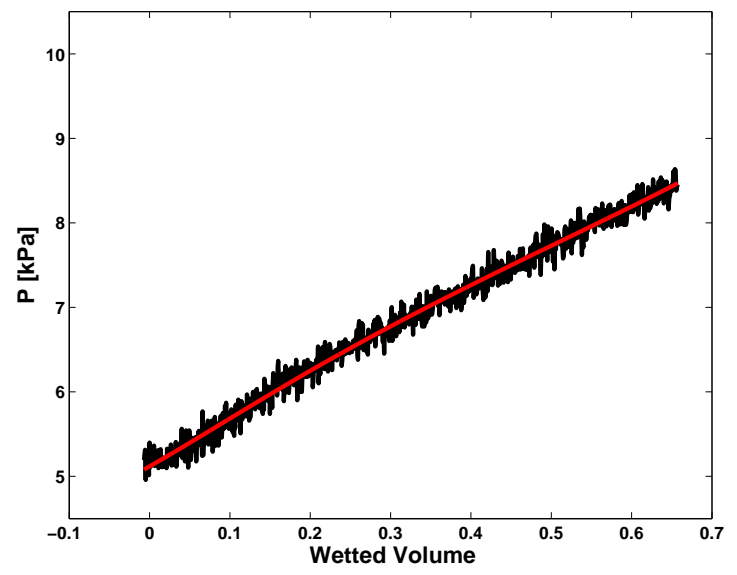

(c) $1^{\text {st }}$ test at $68.95 \mathrm{kPa}$.

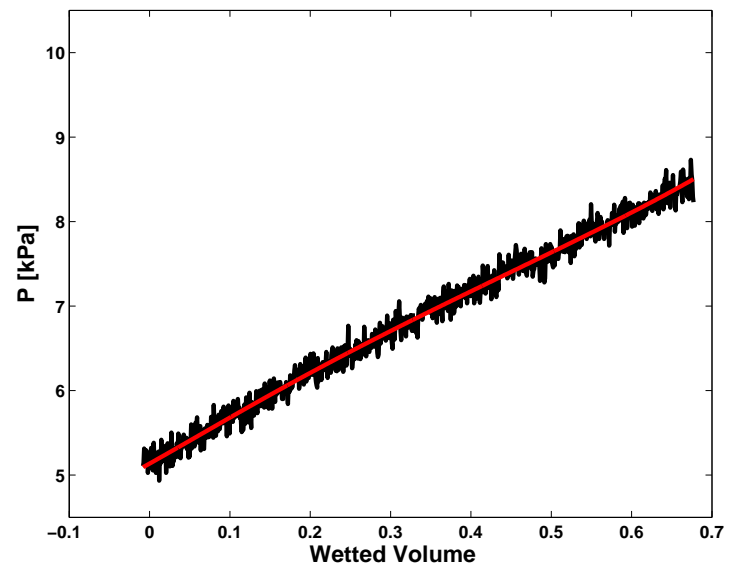

(e) $1^{\text {st }}$ test at $96.53 \mathrm{kPa}$.

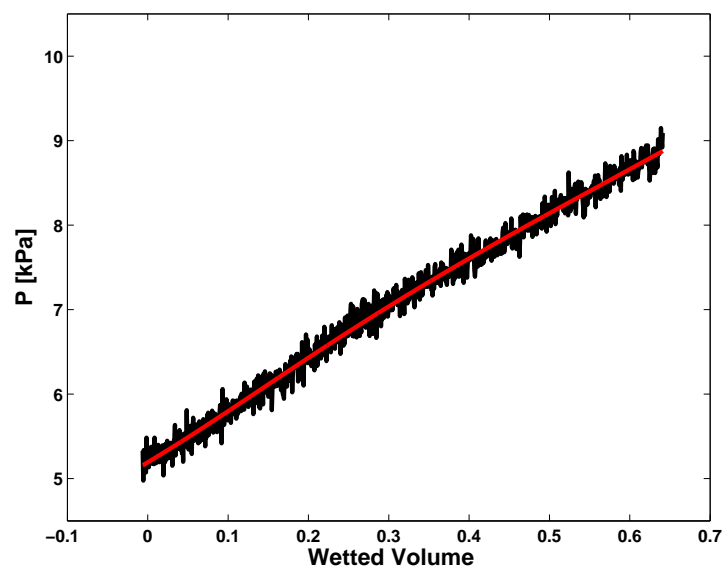

(b) $1^{\text {st }}$ test at $41.37 \mathrm{kPa}$.

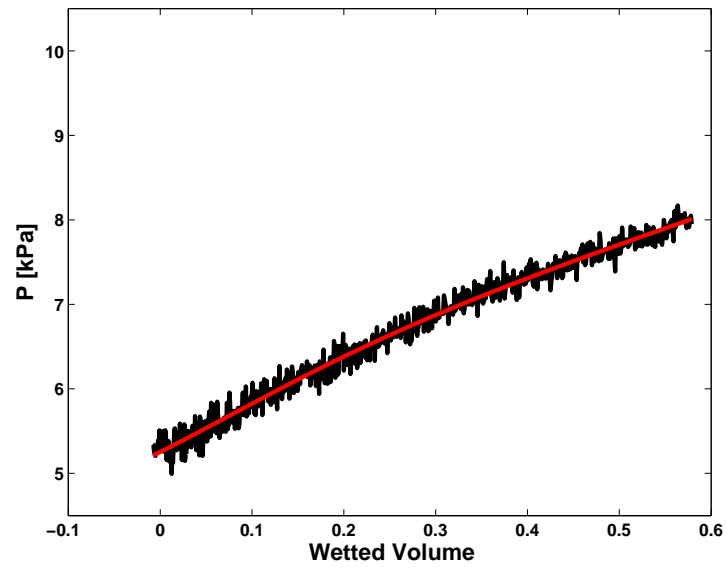

(d) $2^{\text {nd }}$ test at $68.95 \mathrm{kPa}$.

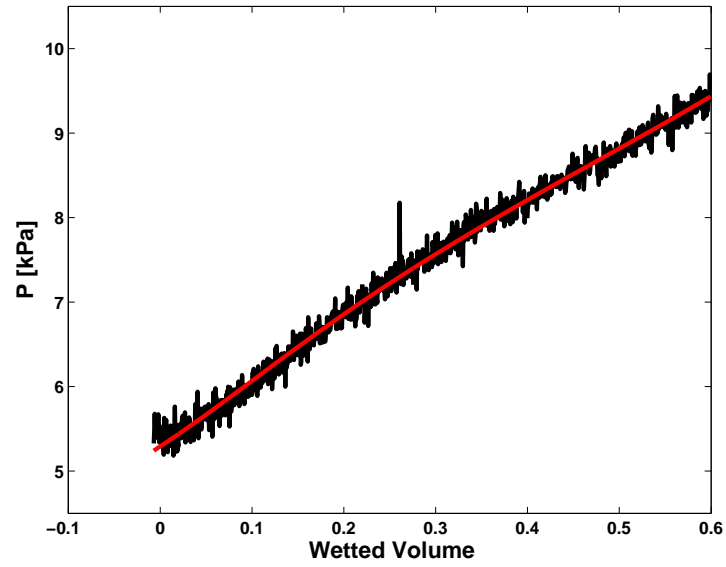

(f) $2^{\text {nd }}$ test at $96.53 \mathrm{kPa}$.

Figure I.9. Percolation pressure vs wetted volume for VD423. The tests were conducted at three different compressions on the sample $41.37 \mathrm{kPa}, 68.95 \mathrm{kPa}$, $96.53 \mathrm{kPa}$ while holding the flow rate constant at $37.08 \mathrm{E}-4 \mathrm{mLs}^{-1}$. 


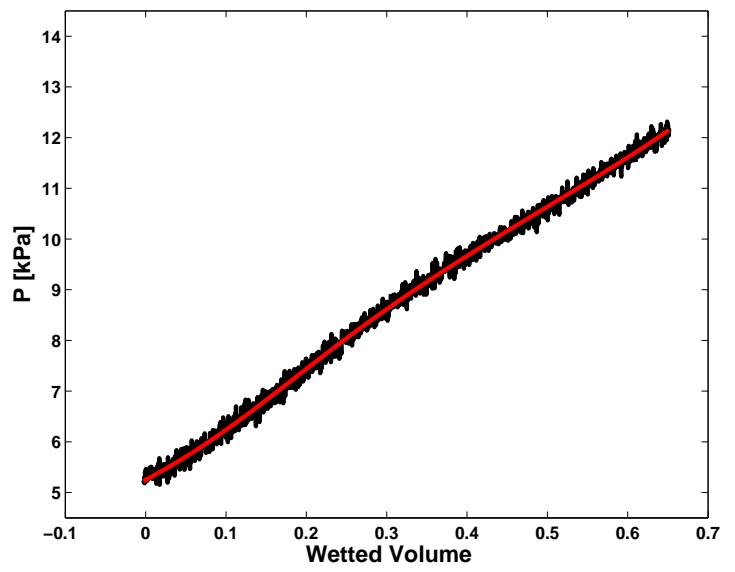

(a) Test at $41.37 \mathrm{kPa}$.

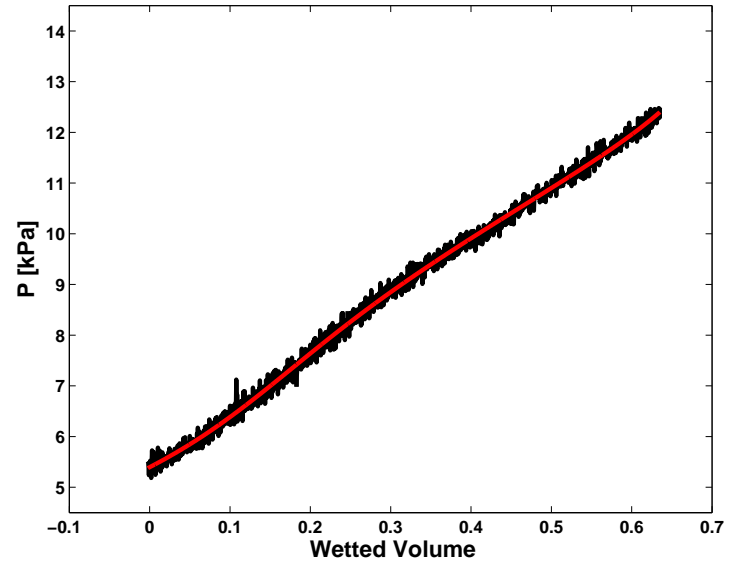

(b) $1^{\text {st }}$ test at $68.95 \mathrm{kPa}$.

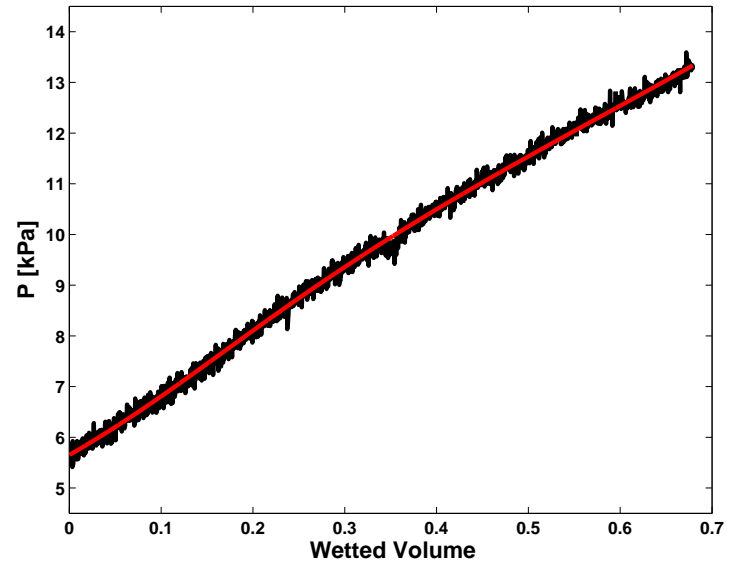

(c) $1^{\text {st }}$ test at $96.53 \mathrm{kPa}$.

Figure I.10. Percolation pressure vs wetted volume for VD422. The tests were conducted at three different compressions on the sample $41.37 \mathrm{kPa}$, $68.95 \mathrm{kPa}, 96.53 \mathrm{kPa}$ while holding the flow rate constant at $9.48 \mathrm{E}$ $4 \mathrm{mLs}^{-1}$. 


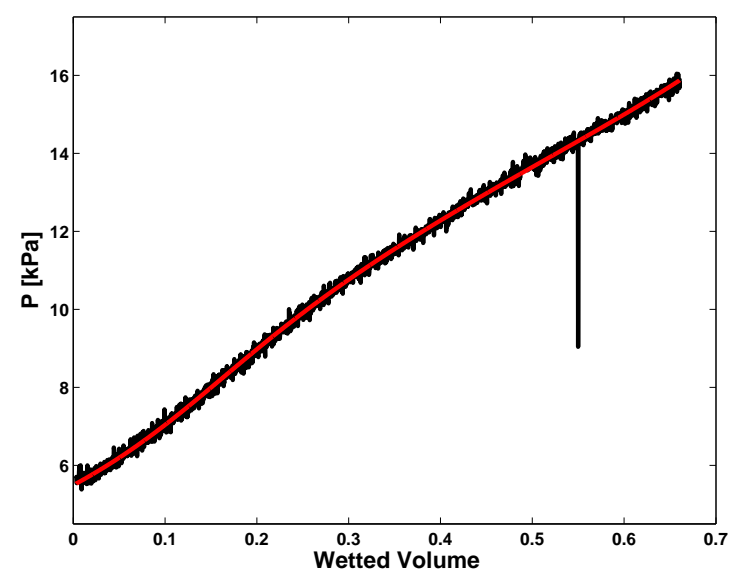

(a) $1^{\text {st }}$ test at $41.37 \mathrm{kPa}$.

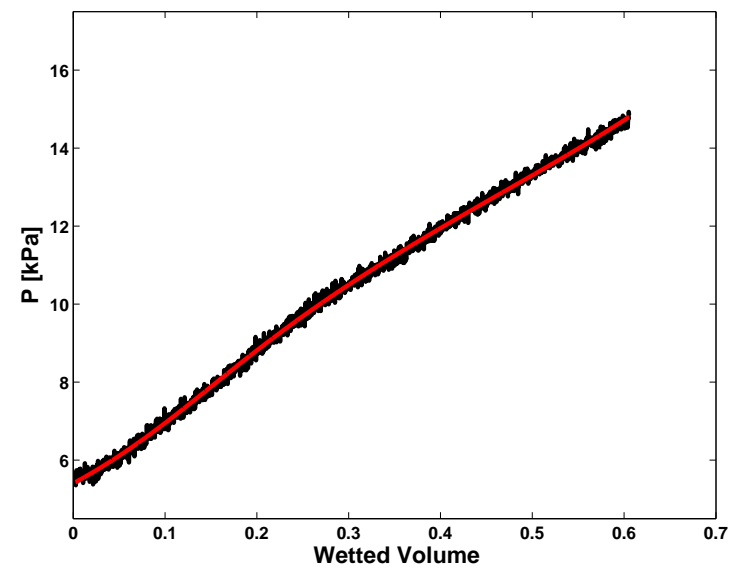

(c) $1^{\text {st }}$ test at $68.95 \mathrm{kPa}$.

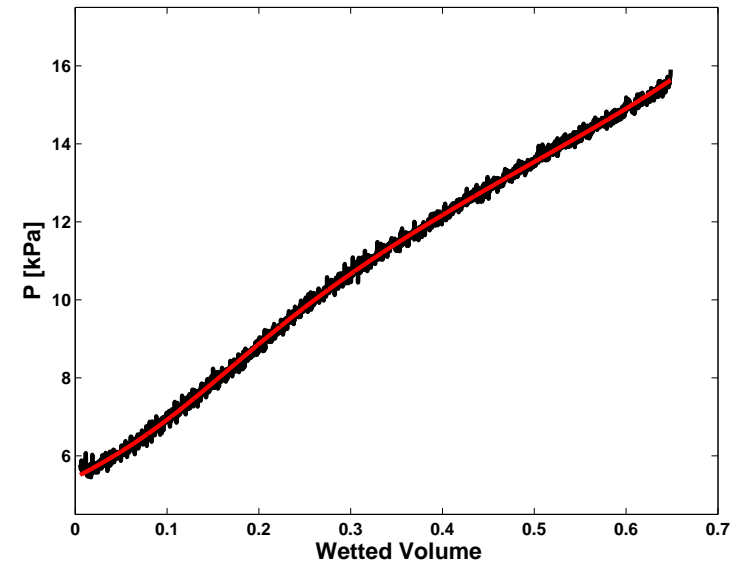

(e) $1^{\text {st }}$ test at $96.53 \mathrm{kPa}$.

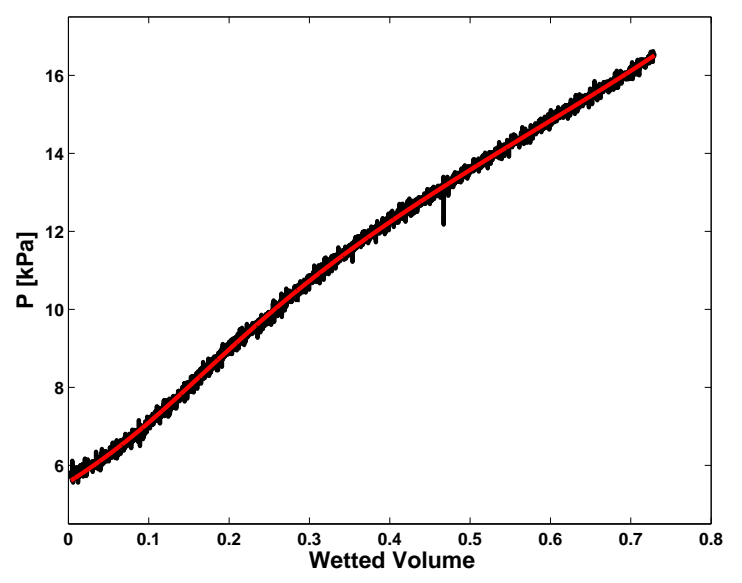

(b) $1^{\text {st }}$ test at $41.37 \mathrm{kPa}$.

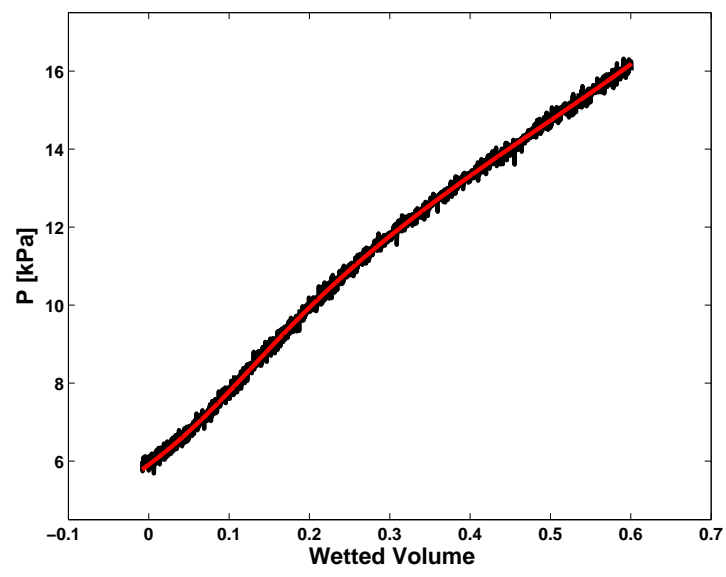

(d) $2^{\text {nd }}$ test at $68.95 \mathrm{kPa}$.

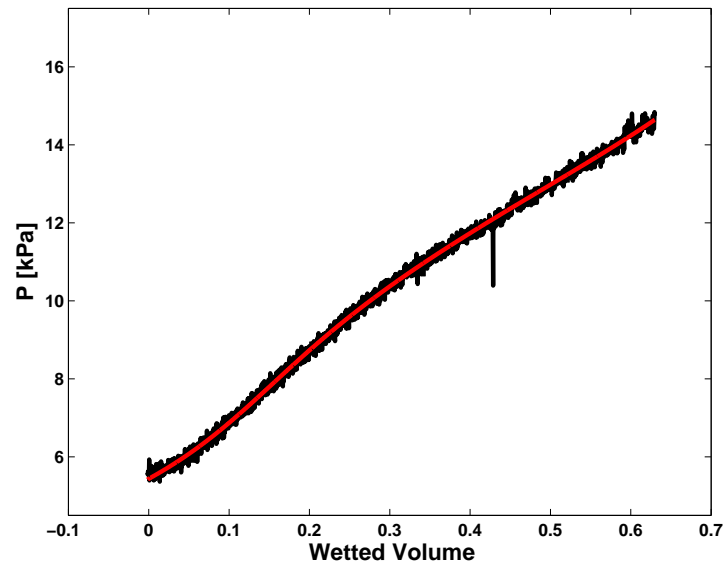

(f) $2^{\text {nd }}$ test at $96.53 \mathrm{kPa}$.

Figure I.11. Percolation pressure vs wetted volume for VD422. The tests were conducted at three different compressions on the sample $41.37 \mathrm{kPa}$, $68.95 \mathrm{kPa}, 96.53 \mathrm{kPa}$ while holding the flow rate constant at $18.75 \mathrm{E}-$ $4 \mathrm{mLs}^{-1}$. 


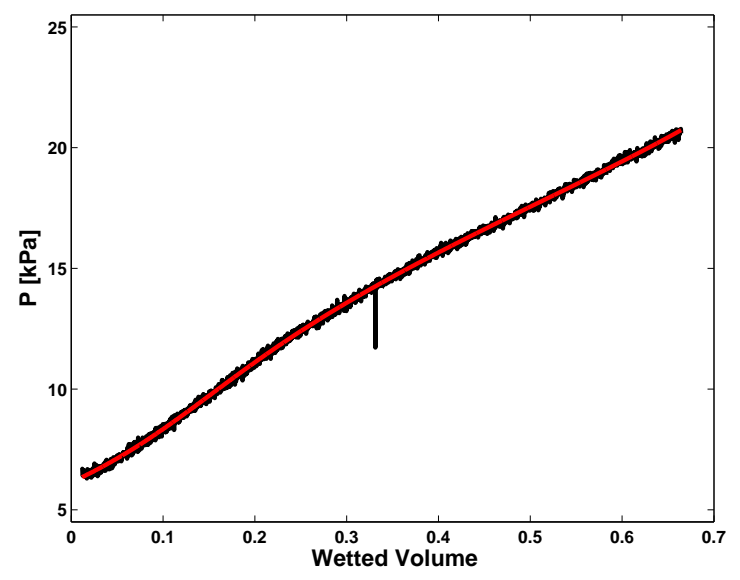

(a) $1^{\text {st }}$ test at $41.37 \mathrm{kPa}$.

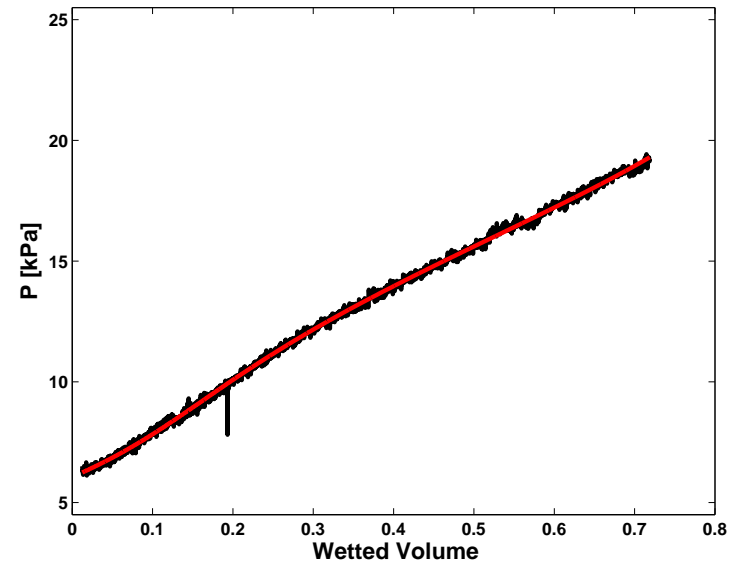

(c) $1^{\text {st }}$ test at $68.95 \mathrm{kPa}$.

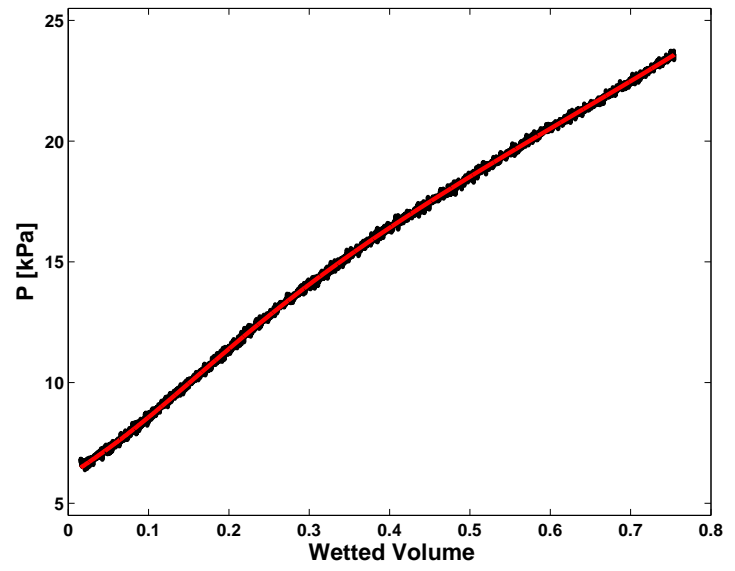

(e) $1^{\text {st }}$ test at $96.53 \mathrm{kPa}$.

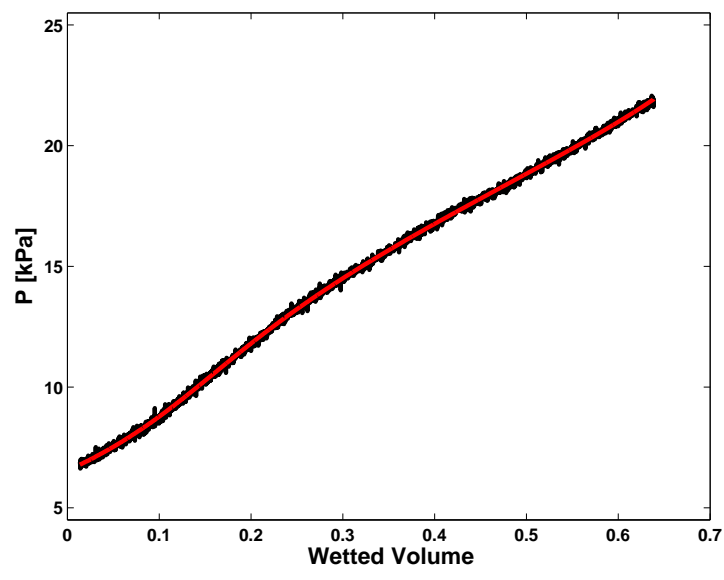

(b) $1^{\text {st }}$ test at $41.37 \mathrm{kPa}$.

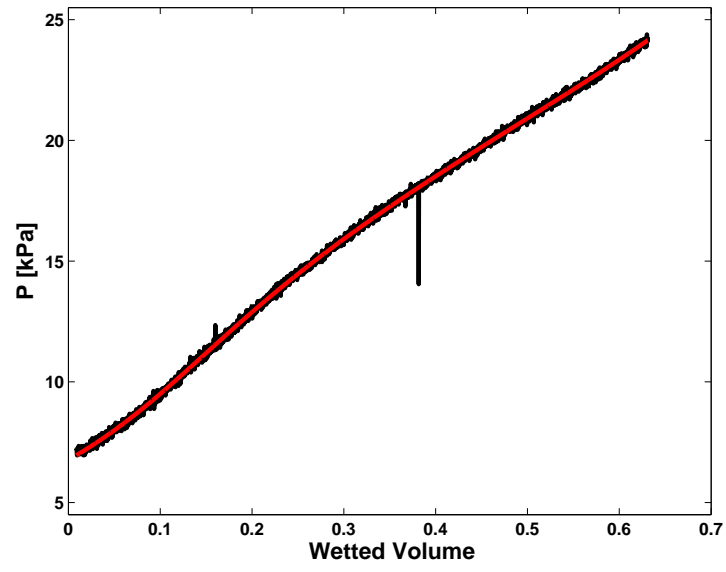

(d) $2^{\text {nd }}$ test at $68.95 \mathrm{kPa}$.

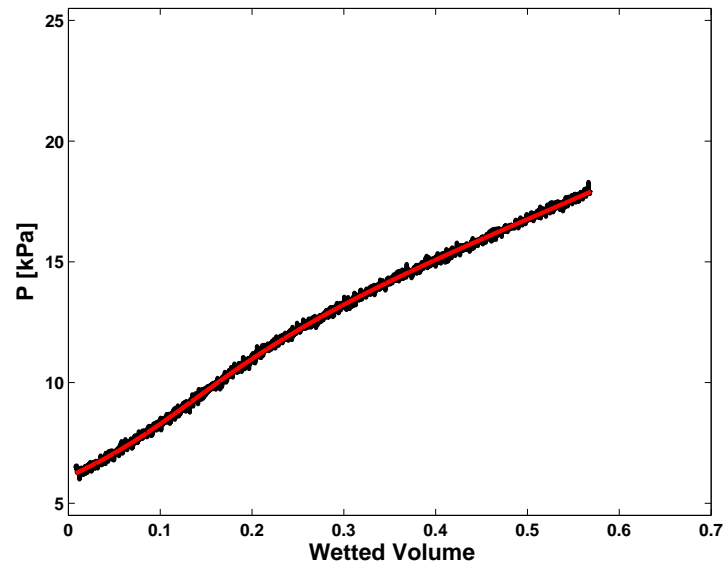

(f) $2^{\text {nd }}$ test at $96.53 \mathrm{kPa}$.

Figure I.12. Percolation pressure vs wetted volume for VD422. The tests were conducted at three different compressions on the sample $41.37 \mathrm{kPa}$, $68.95 \mathrm{kPa}, 96.53 \mathrm{kPa}$ while holding the flow rate constant at $37.08 \mathrm{E}$ $4 \mathrm{mLs}^{-1}$. 


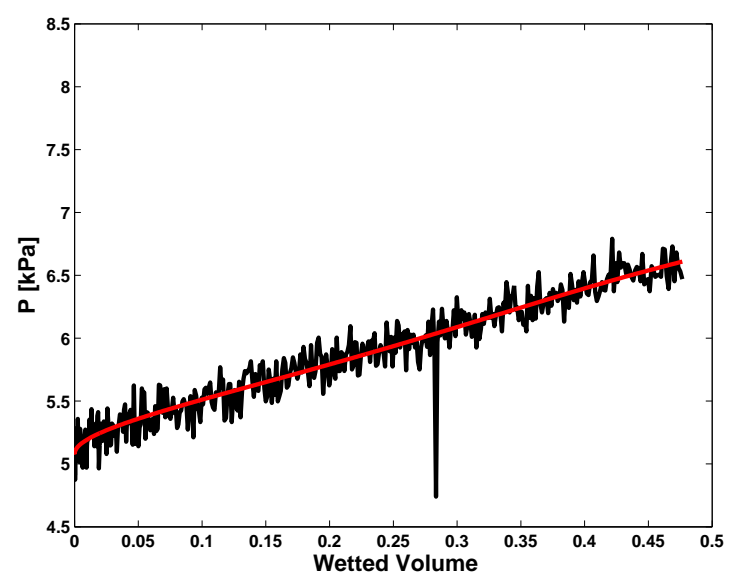

(a) Test at $41.37 \mathrm{kPa}$.

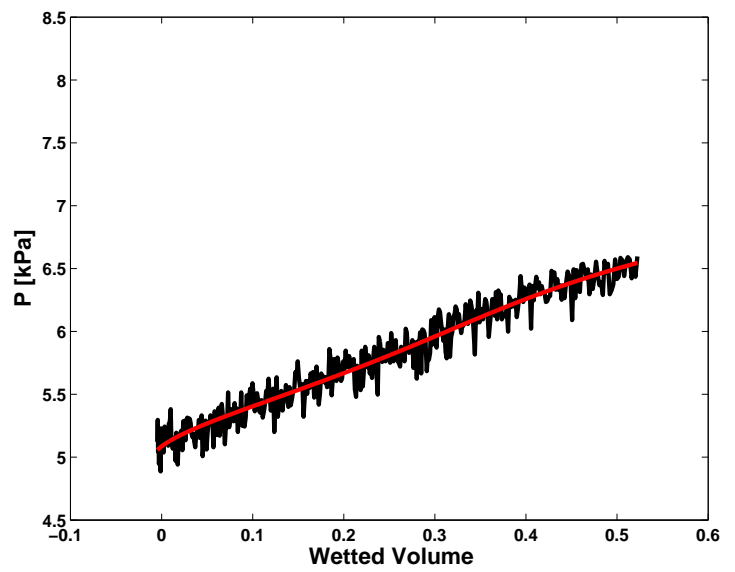

(b) $1^{\text {st }}$ test at $68.95 \mathrm{kPa}$.

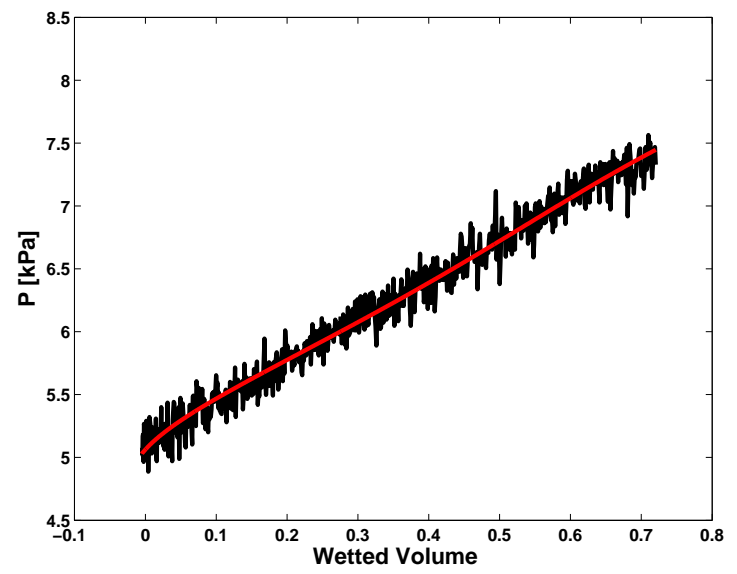

(c) $1^{\text {st }}$ test at $96.53 \mathrm{kPa}$.

Figure I.13. Percolation pressure vs wetted volume for VD424. The tests were conducted at three different compressions on the sample $41.37 \mathrm{kPa}$, $68.95 \mathrm{kPa}, 96.53 \mathrm{kPa}$ while holding the flow rate constant at $9.48 \mathrm{E}$ $4 \mathrm{mLs}^{-1}$. 


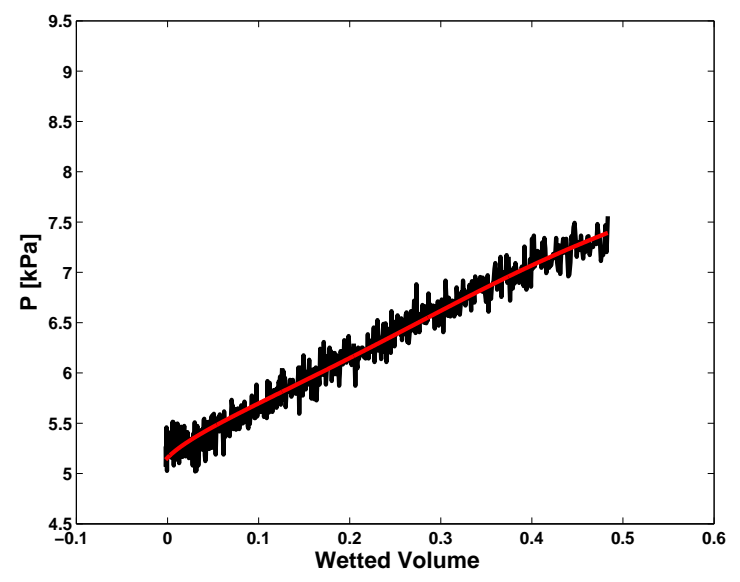

(a) $1^{\text {st }}$ test at $41.37 \mathrm{kPa}$.

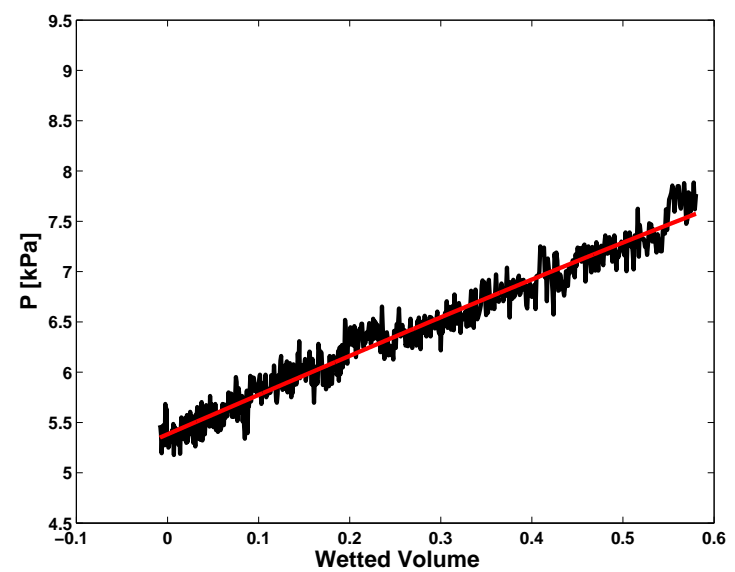

(c) $1^{\text {st }}$ test at $68.95 \mathrm{kPa}$.

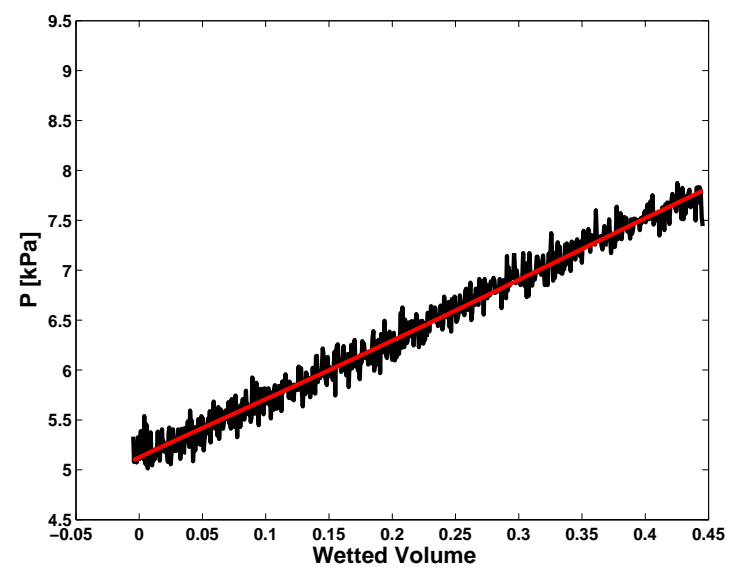

(e) $1^{\text {st }}$ test at $96.53 \mathrm{kPa}$.

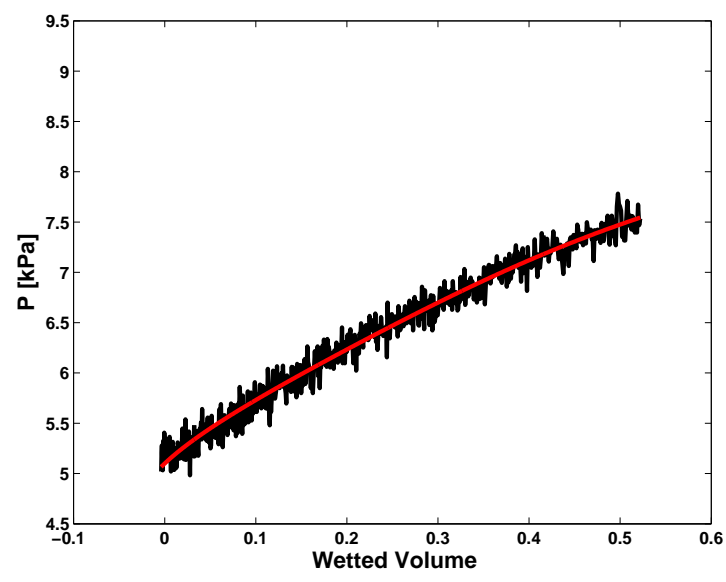

(b) $1^{\text {st }}$ test at $41.37 \mathrm{kPa}$.

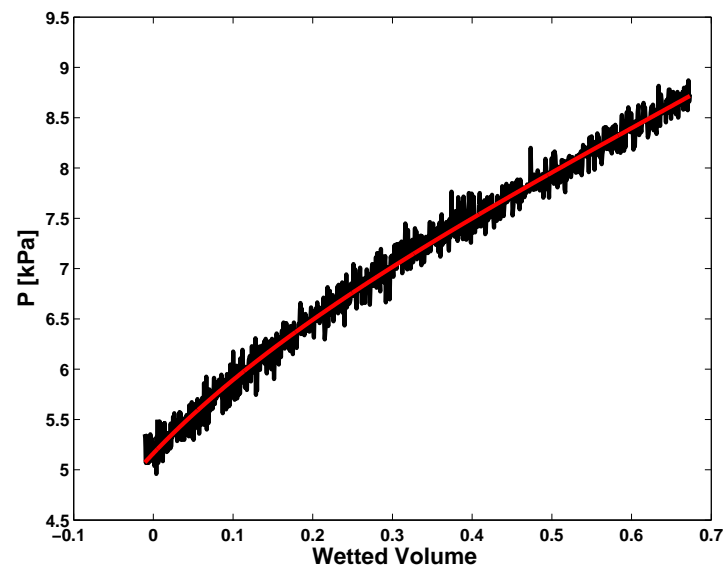

(d) $2^{\text {nd }}$ test at $68.95 \mathrm{kPa}$.

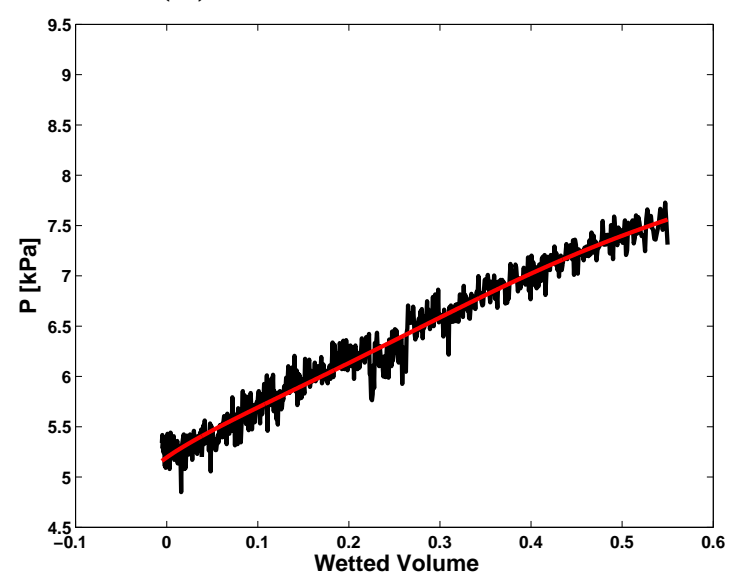

(f) $2^{\text {nd }}$ test at $96.53 \mathrm{kPa}$.

Figure I.14. Percolation pressure vs wetted volume for VD424. The tests were conducted at three different compressions on the sample $41.37 \mathrm{kPa}$, $68.95 \mathrm{kPa}, 96.53 \mathrm{kPa}$ while holding the flow rate constant at $18.75 \mathrm{E}-$ $4 \mathrm{mLs}^{-1}$. 


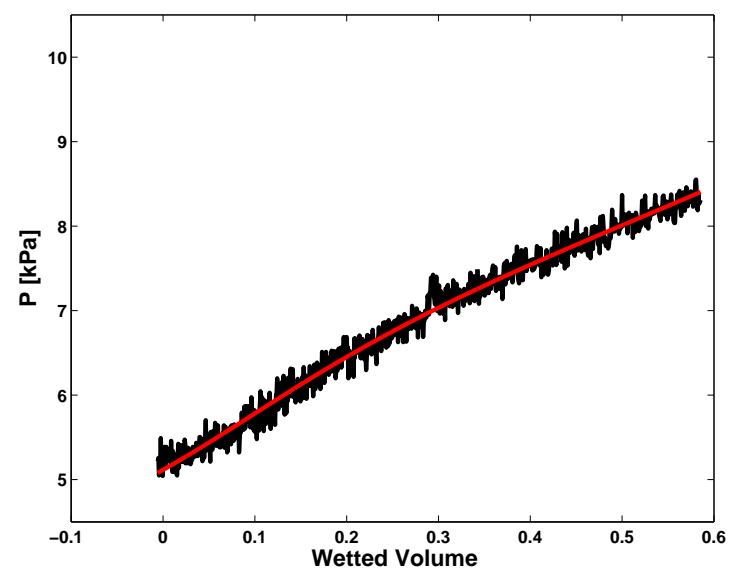

(a) $1^{\text {st }}$ test at $41.37 \mathrm{kPa}$.

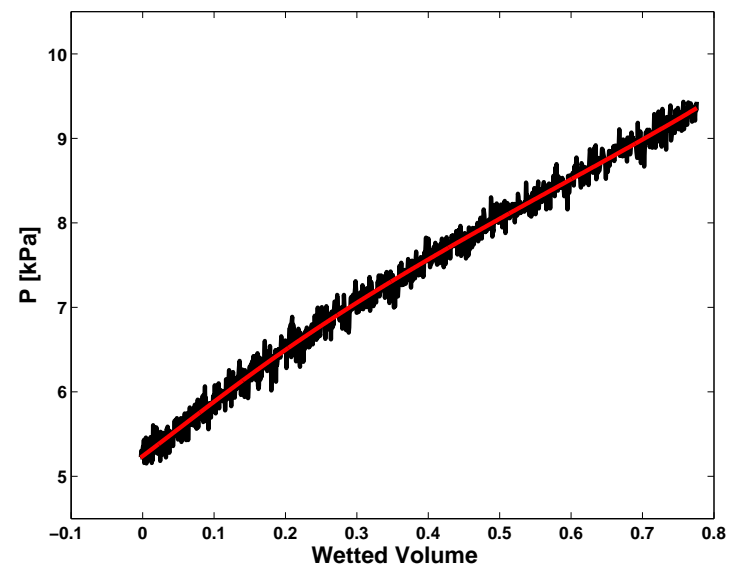

(c) $1^{\text {st }}$ test at $68.95 \mathrm{kPa}$.

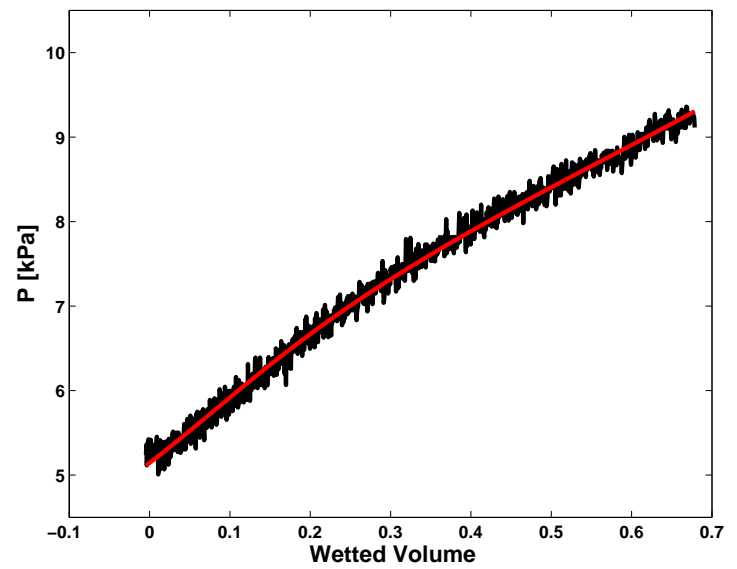

(e) $1^{\text {st }}$ test at $96.53 \mathrm{kPa}$.

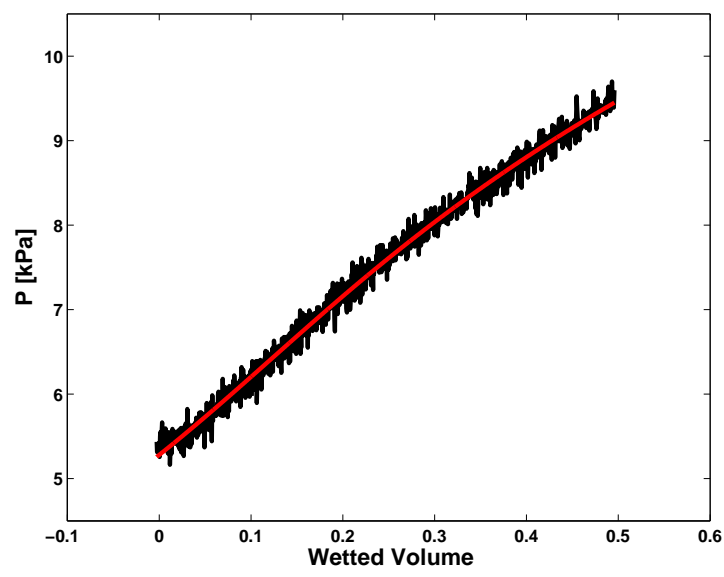

(b) $1^{\text {st }}$ test at $41.37 \mathrm{kPa}$.

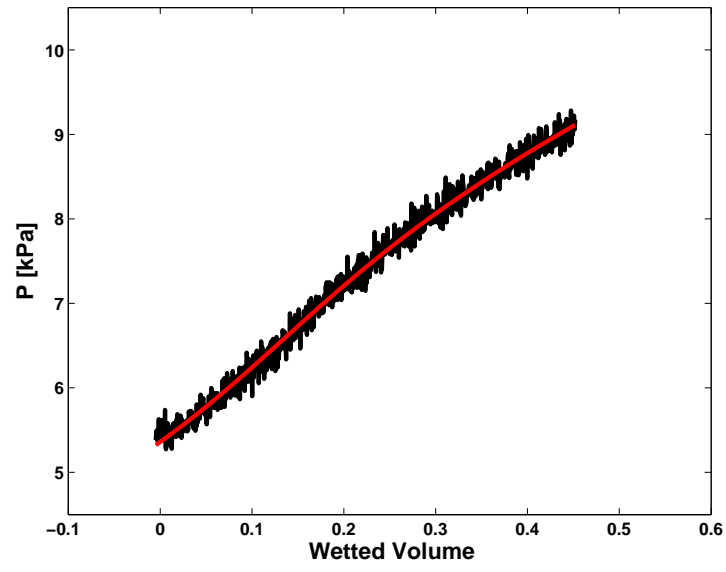

(d) $2^{\text {nd }}$ test at $68.95 \mathrm{kPa}$.

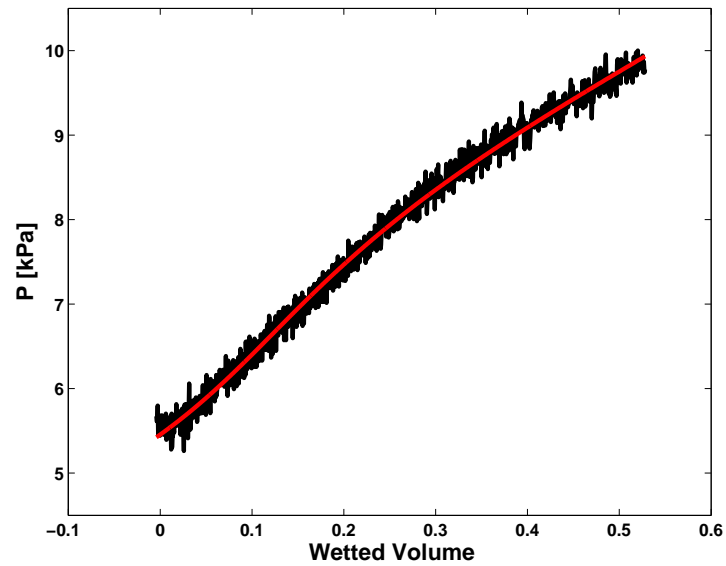

(f) $2^{\text {nd }}$ test at $96.53 \mathrm{kPa}$.

Figure I.15. Percolation pressure vs wetted volume for VD424. The tests were conducted at three different compressions on the sample $41.37 \mathrm{kPa}$, $68.95 \mathrm{kPa}, 96.53 \mathrm{kPa}$ while holding the flow rate constant at $37.08 \mathrm{E}$ $4 \mathrm{mLs}^{-1}$. 


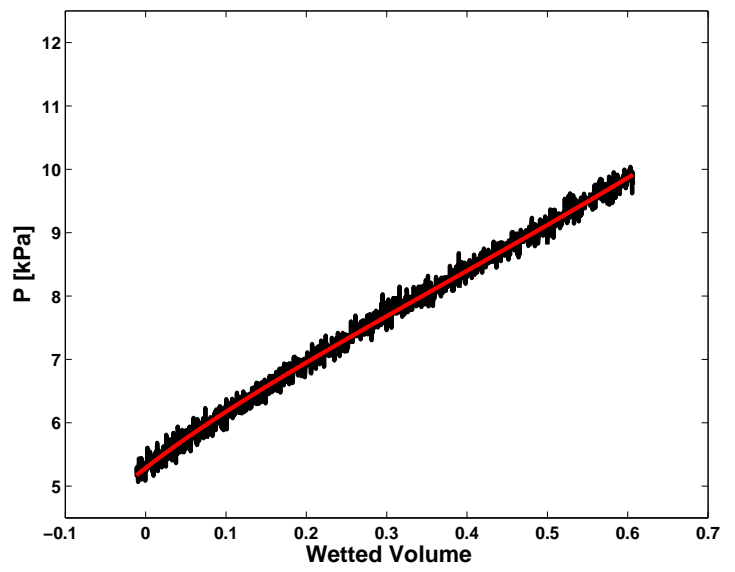

(a) Test at $41.37 \mathrm{kPa}$.

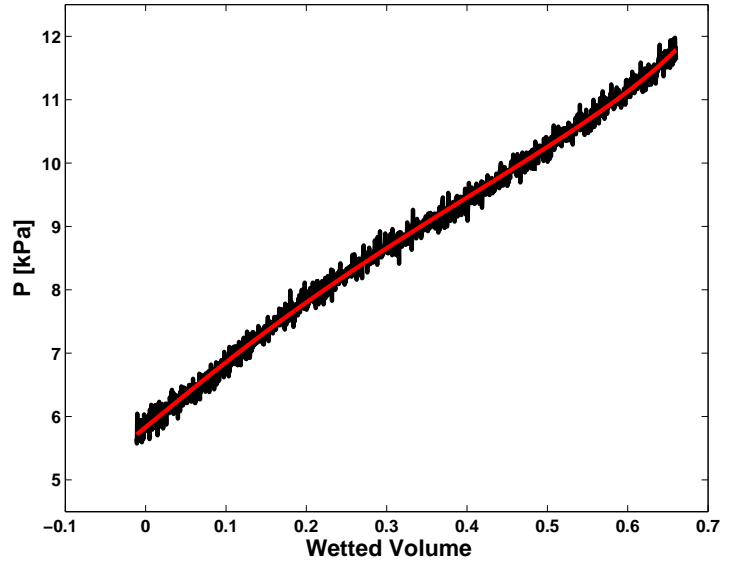

(b) $1^{\text {st }}$ test at $68.95 \mathrm{kPa}$.

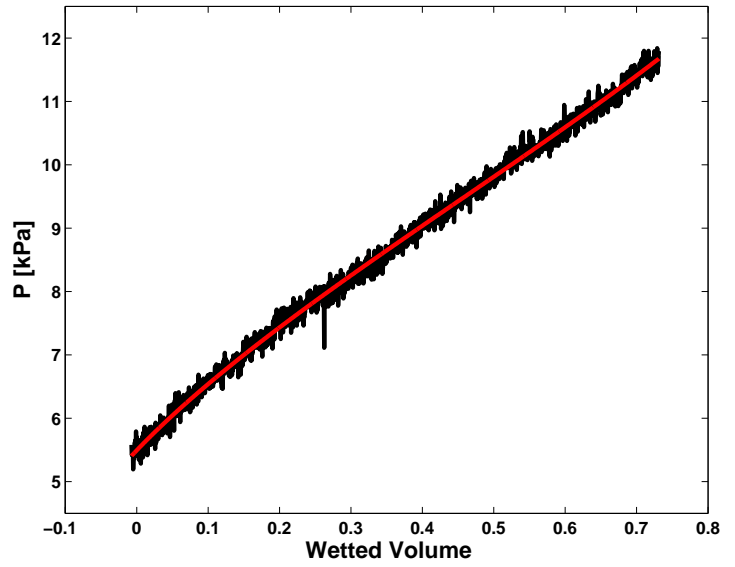

(c) $1^{\text {st }}$ test at $96.53 \mathrm{kPa}$.

Figure I.16. Percolation pressure vs wetted volume for VD425. The tests were conducted at three different compressions on the sample $41.37 \mathrm{kPa}$, $68.95 \mathrm{kPa}, 96.53 \mathrm{kPa}$ while holding the flow rate constant at $9.48 \mathrm{E}$ $4 \mathrm{mLs}^{-1}$. 


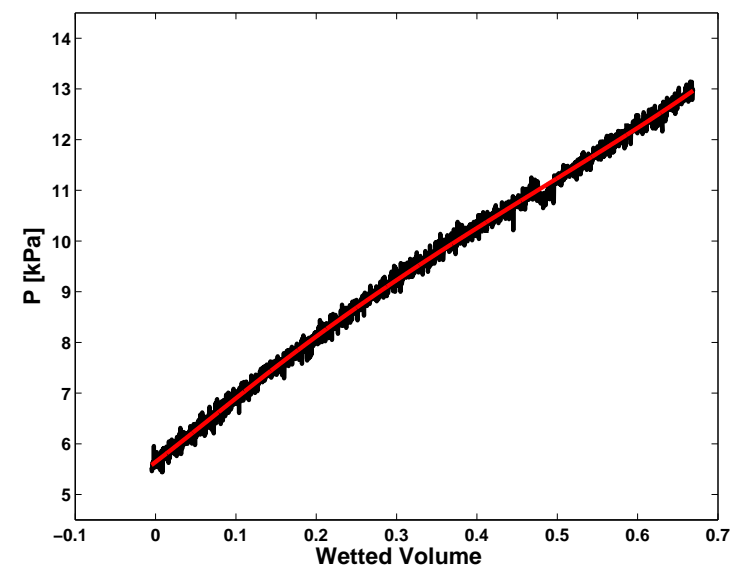

(a) $1^{\text {st }}$ test at $41.37 \mathrm{kPa}$.

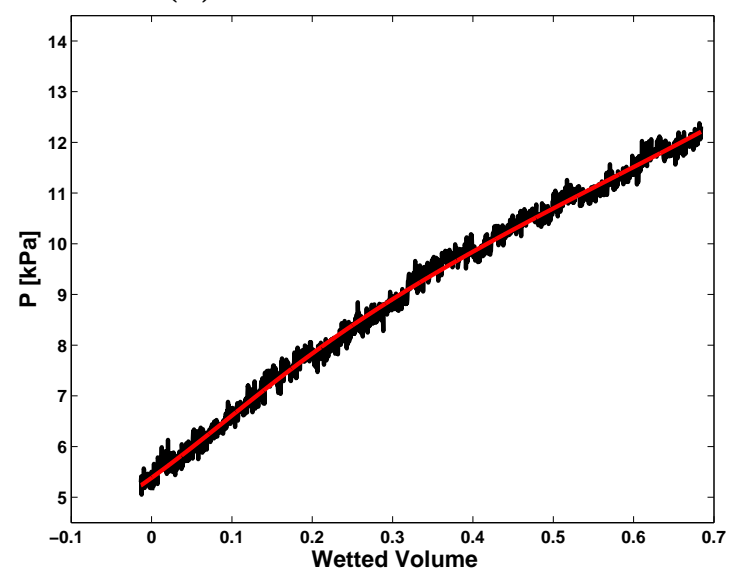

(c) $1^{\text {st }}$ test at $68.95 \mathrm{kPa}$.

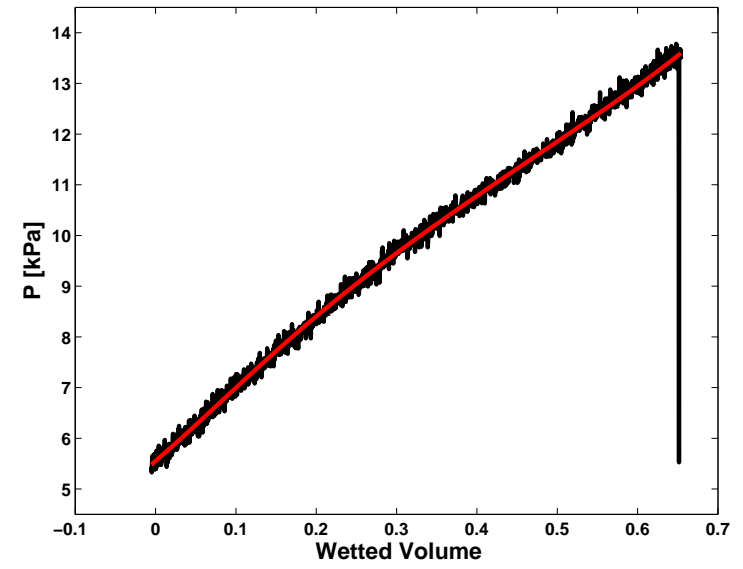

(e) $1^{\text {st }}$ test at $96.53 \mathrm{kPa}$.

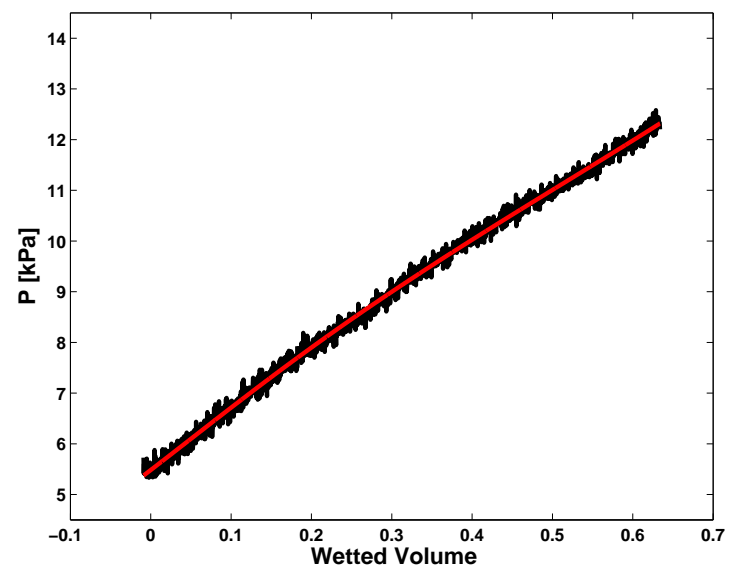

(b) $1^{\text {st }}$ test at $41.37 \mathrm{kPa}$.

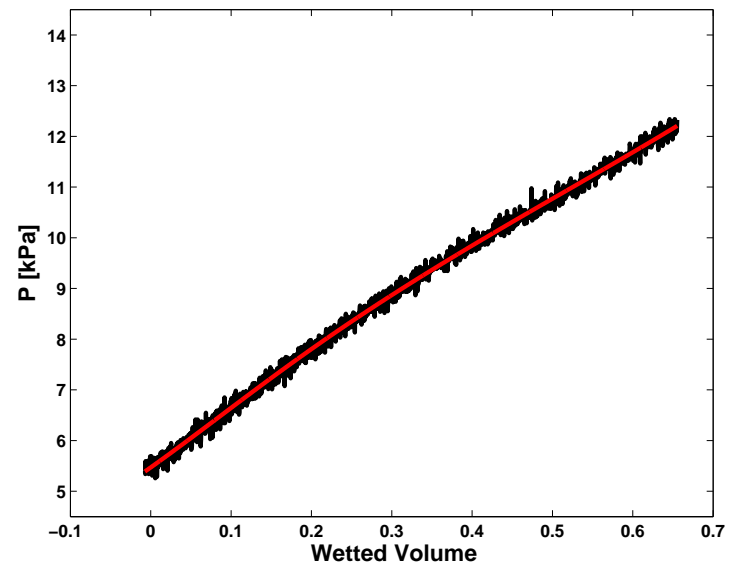

(d) $2^{\text {nd }}$ test at $68.95 \mathrm{kPa}$.

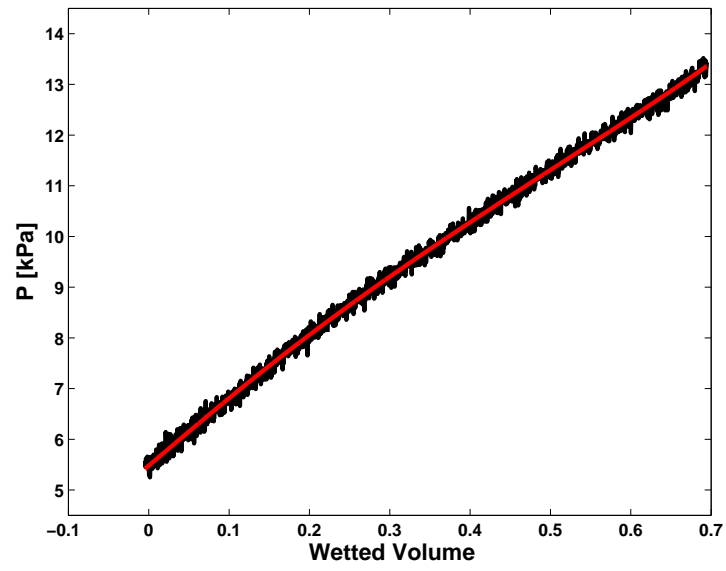

(f) $2^{\text {nd }}$ test at $96.53 \mathrm{kPa}$.

Figure I.17. Percolation pressure vs wetted volume for VD425. The tests were conducted at three different compressions on the sample $41.37 \mathrm{kPa}$, $68.95 \mathrm{kPa}, 96.53 \mathrm{kPa}$ while holding the flow rate constant at $18.75 \mathrm{E}-$ $4 \mathrm{mLs}^{-1}$. 


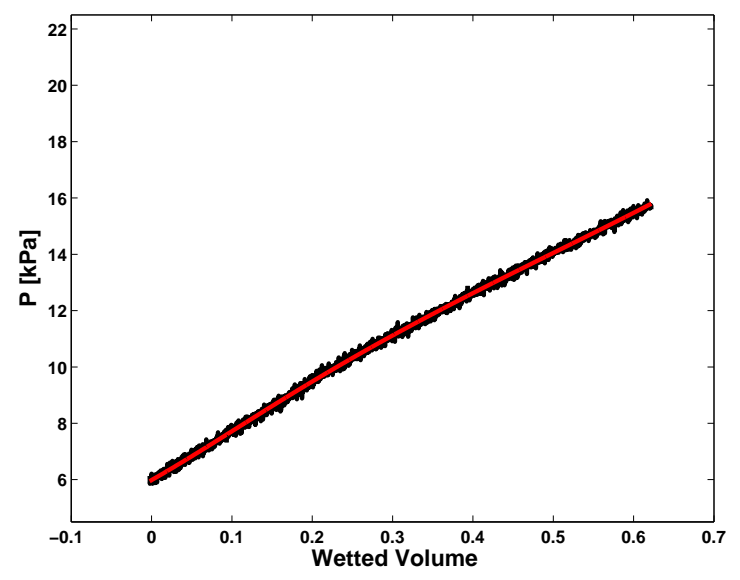

(a) $1^{\text {st }}$ test at $41.37 \mathrm{kPa}$.

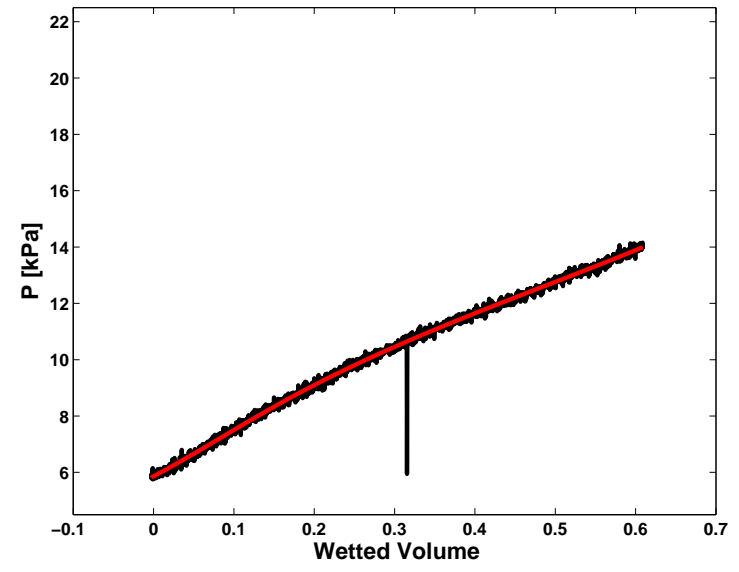

(c) $1^{\text {st }}$ test at $68.95 \mathrm{kPa}$.

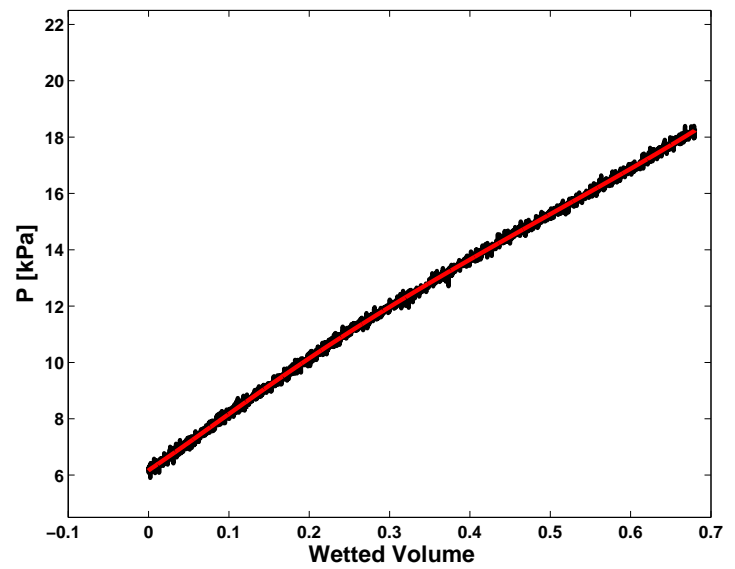

(e) $1^{\text {st }}$ test at $96.53 \mathrm{kPa}$.

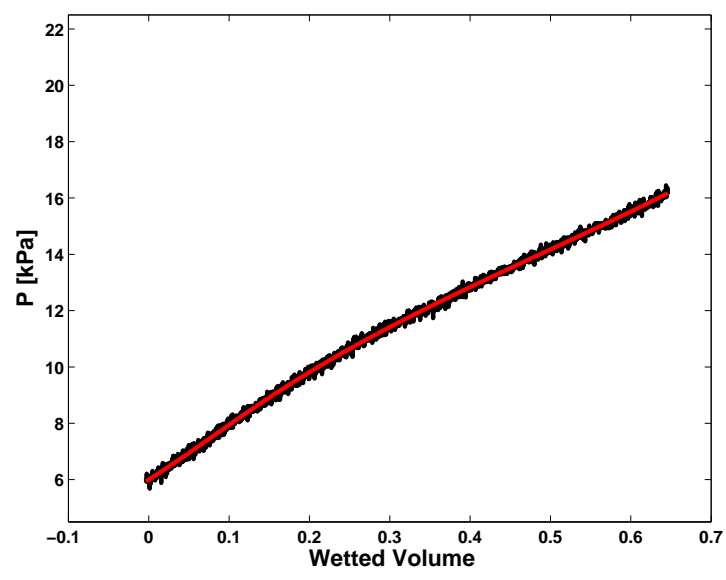

(b) $1^{\text {st }}$ test at $41.37 \mathrm{kPa}$.

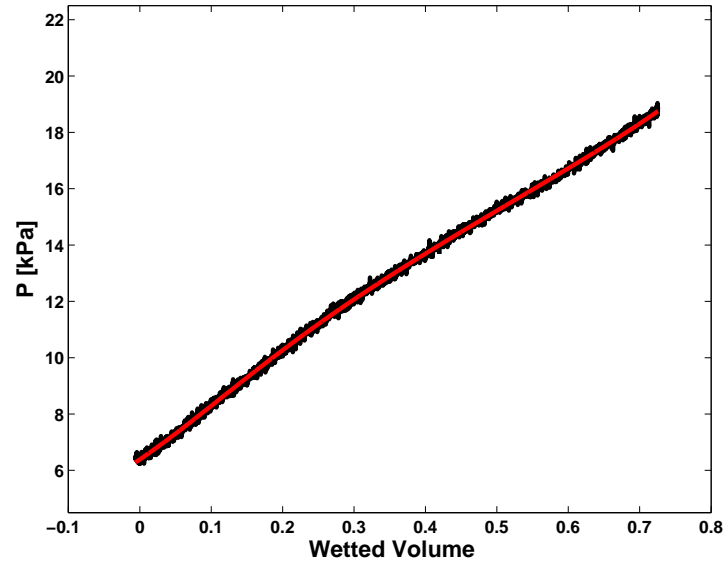

(d) $2^{\text {nd }}$ test at $68.95 \mathrm{kPa}$.

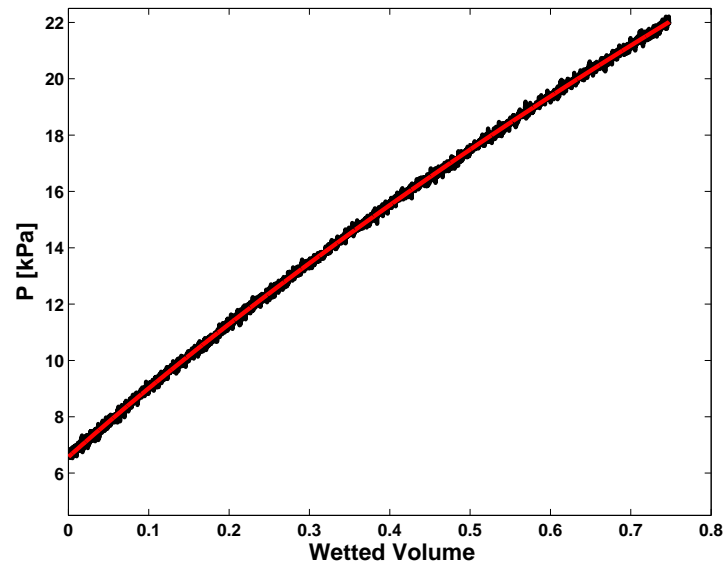

(f) $2^{\text {nd }}$ test at $96.53 \mathrm{kPa}$.

Figure I.18. Percolation pressure vs wetted volume for VD425. The tests were conducted at three different compressions on the sample $41.37 \mathrm{kPa}$, $68.95 \mathrm{kPa}, 96.53 \mathrm{kPa}$ while holding the flow rate constant at $37.08 \mathrm{E}$ $4 \mathrm{mLs}^{-1}$. 


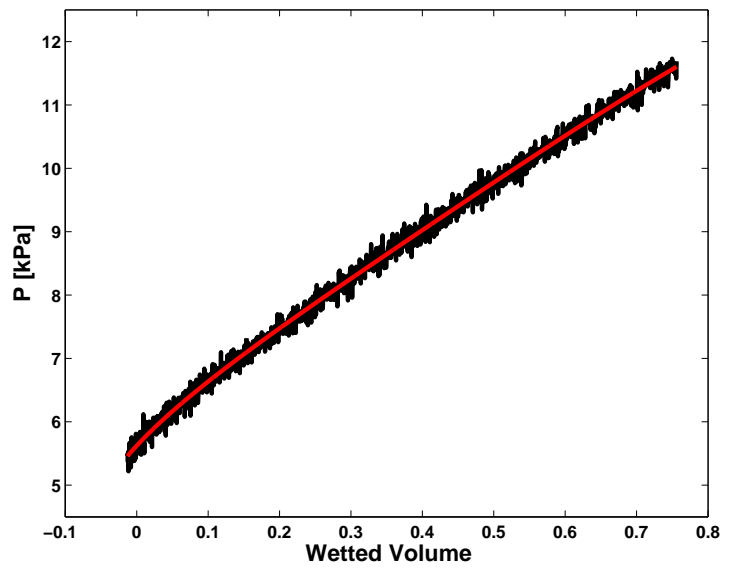

(a) Test at $41.37 \mathrm{kPa}$.

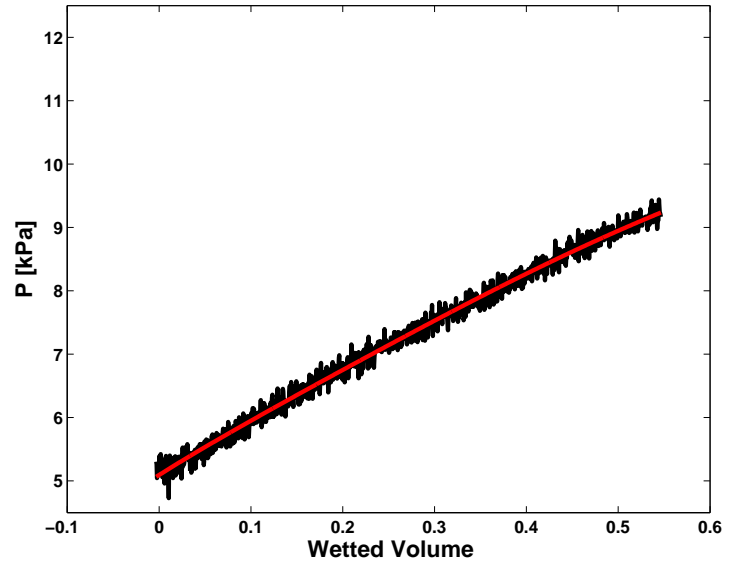

(b) $1^{\text {st }}$ test at $68.95 \mathrm{kPa}$.

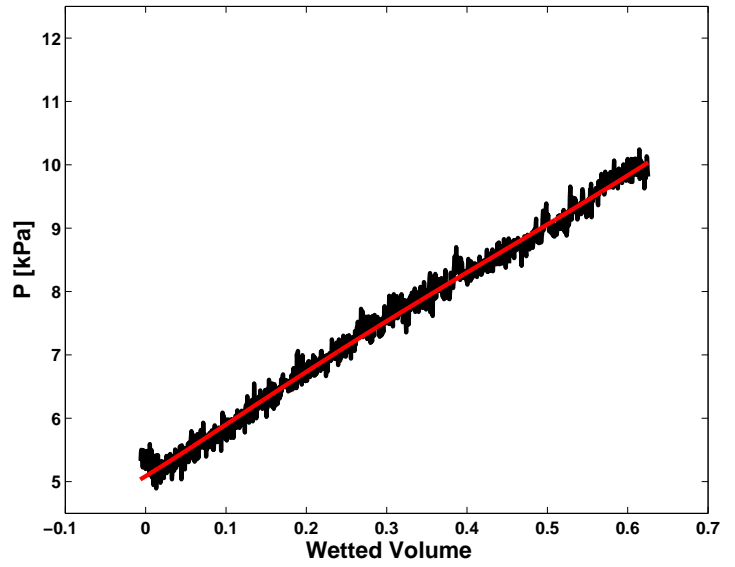

(c) $1^{\text {st }}$ test at $96.53 \mathrm{kPa}$.

Figure I.19. Percolation pressure vs wetted volume for VD432. The tests were conducted at three different compressions on the sample $41.37 \mathrm{kPa}$, $68.95 \mathrm{kPa}, 96.53 \mathrm{kPa}$ while holding the flow rate constant at $9.48 \mathrm{E}-$ $4 \mathrm{mLs}^{-1}$. 


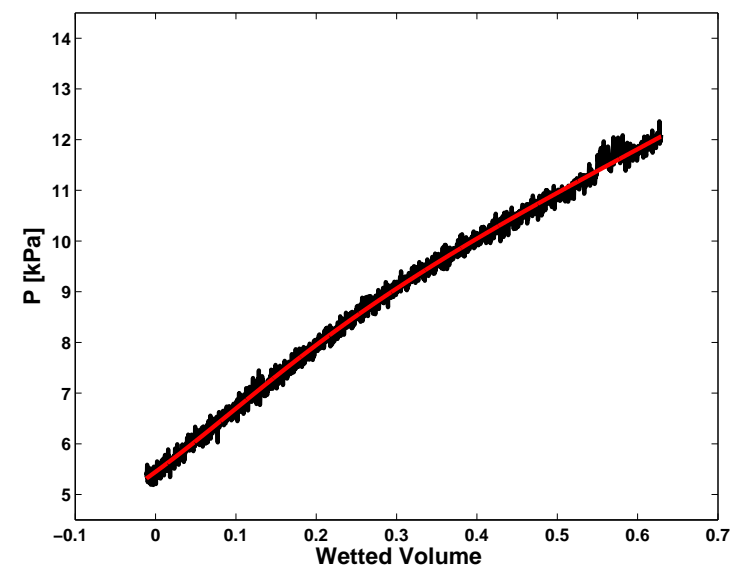

(a) $1^{\text {st }}$ test at $41.37 \mathrm{kPa}$.

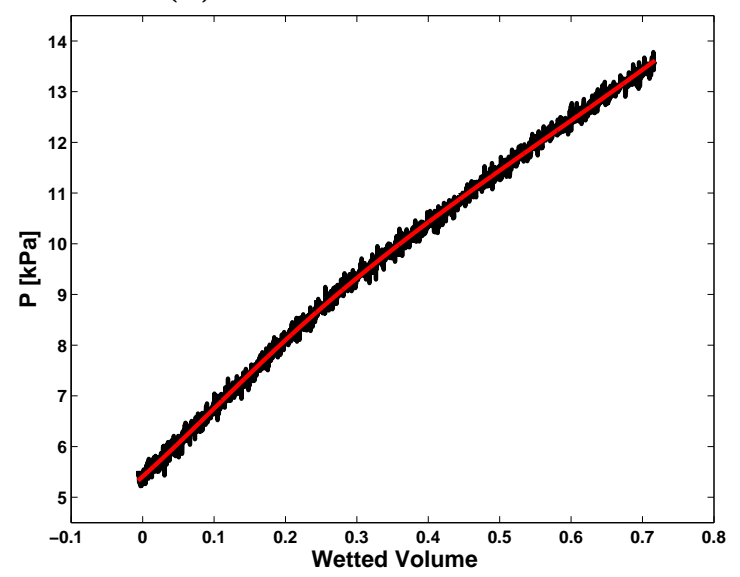

(c) $1^{\text {st }}$ test at $68.95 \mathrm{kPa}$.

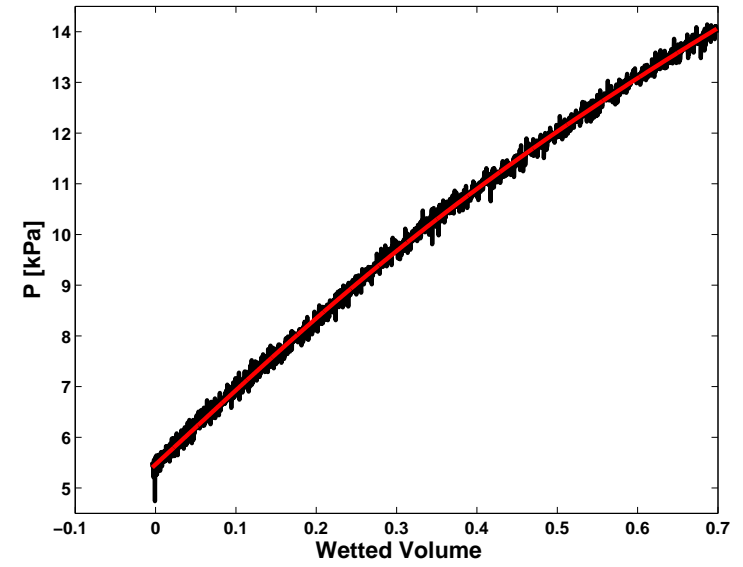

(e) $1^{\text {st }}$ test at $96.53 \mathrm{kPa}$.

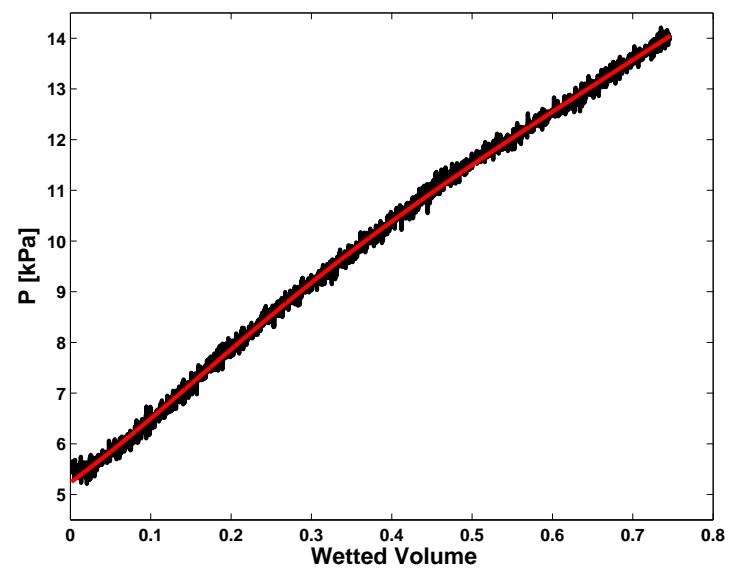

(b) $1^{\text {st }}$ test at $41.37 \mathrm{kPa}$.

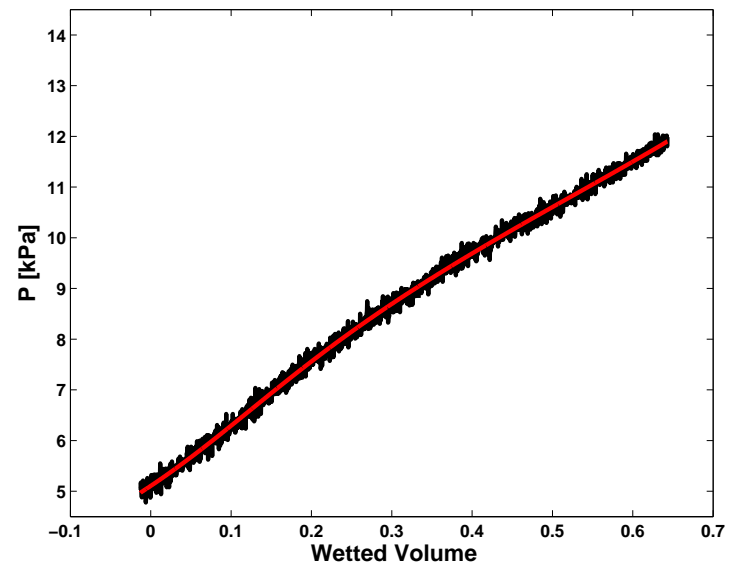

(d) $2^{\text {nd }}$ test at $68.95 \mathrm{kPa}$.

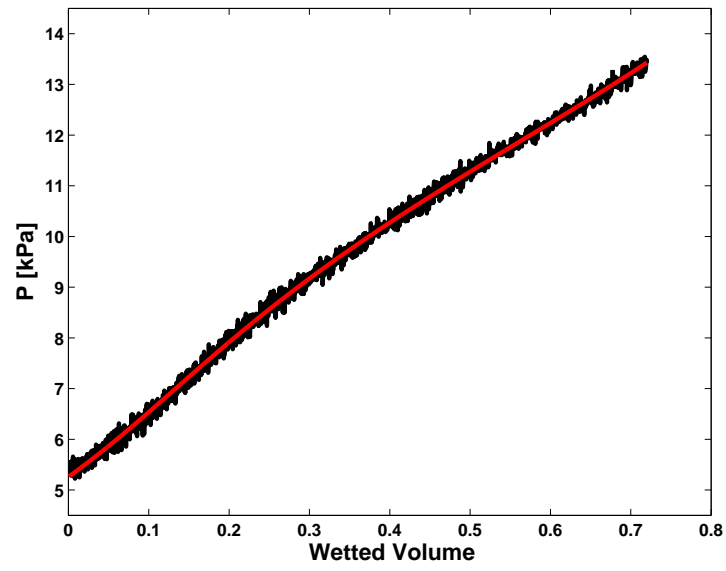

(f) $2^{\text {nd }}$ test at $96.53 \mathrm{kPa}$.

Figure I.20. Percolation pressure vs wetted volume for VD432. The tests were conducted at three different compressions on the sample $41.37 \mathrm{kPa}$, $68.95 \mathrm{kPa}, 96.53 \mathrm{kPa}$ while holding the flow rate constant at $18.75 \mathrm{E}-$ $4 \mathrm{mLs}^{-1}$. 


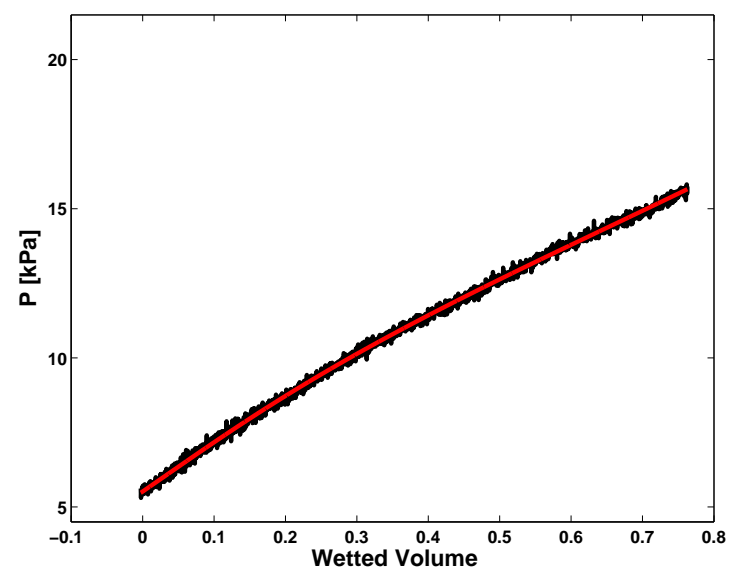

(a) $1^{\text {st }}$ test at $41.37 \mathrm{kPa}$.

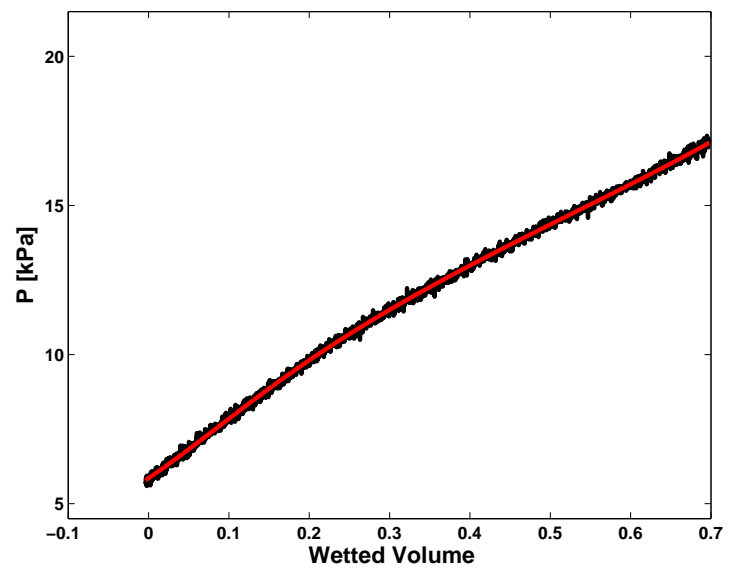

(c) $1^{\text {st }}$ test at $68.95 \mathrm{kPa}$.

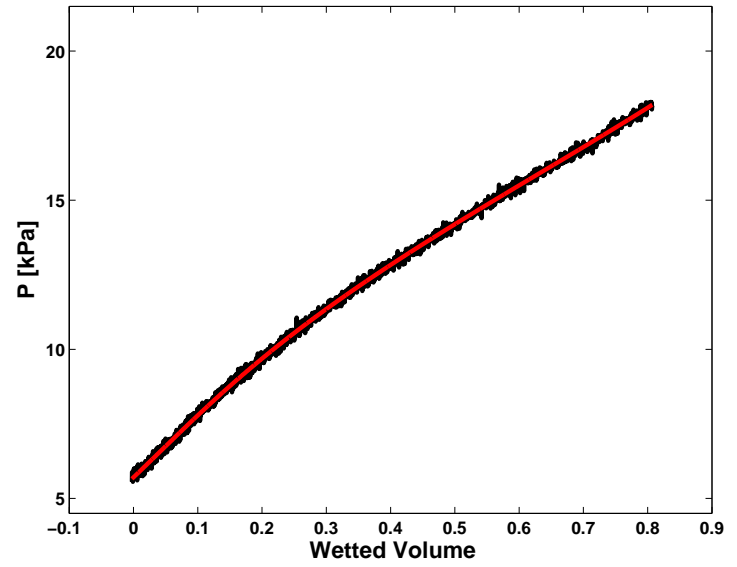

(e) $1^{\text {st }}$ test at $96.53 \mathrm{kPa}$.

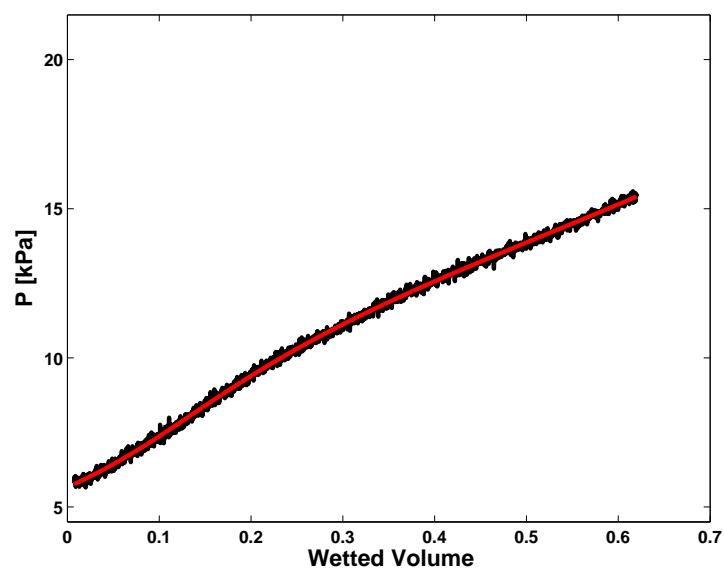

(b) $1^{\text {st }}$ test at $41.37 \mathrm{kPa}$.

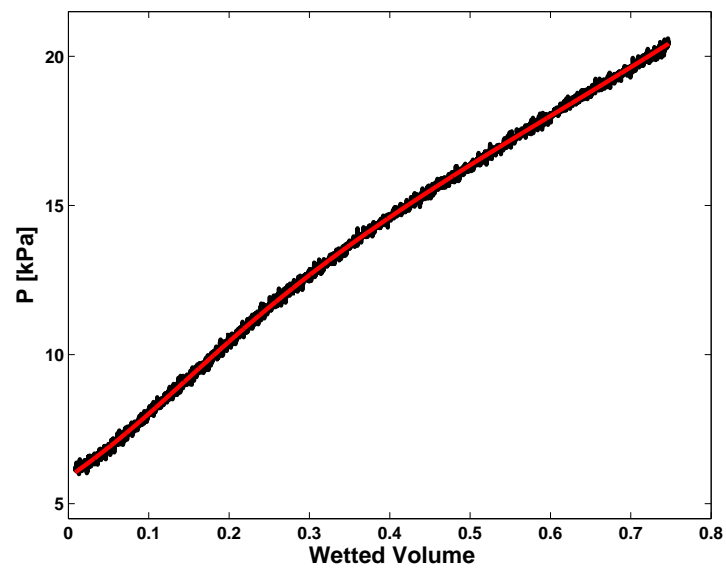

(d) $2^{\text {nd }}$ test at $68.95 \mathrm{kPa}$.

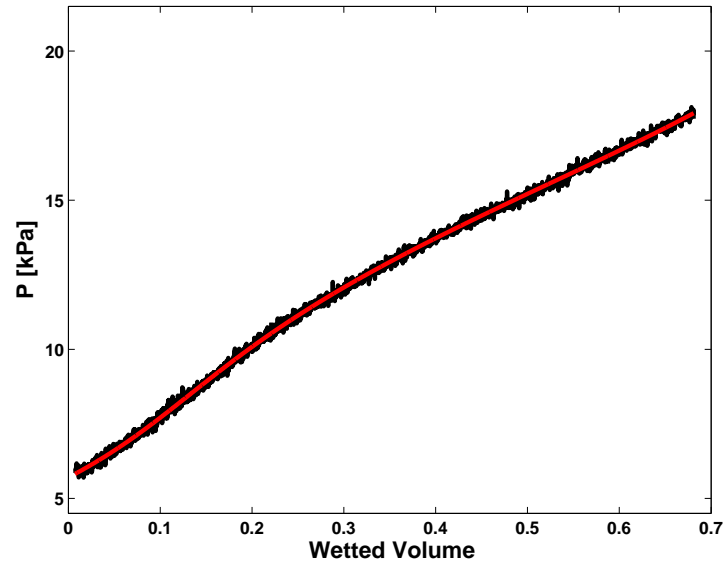

(f) $2^{\text {nd }}$ test at $96.53 \mathrm{kPa}$.

Figure I.21. Percolation pressure vs wetted volume for VD432. The tests were conducted at three different compressions on the sample $41.37 \mathrm{kPa}$, $68.95 \mathrm{kPa}, 96.53 \mathrm{kPa}$ while holding the flow rate constant at $37.08 \mathrm{E}-$ $4 \mathrm{mLs}^{-1}$. 


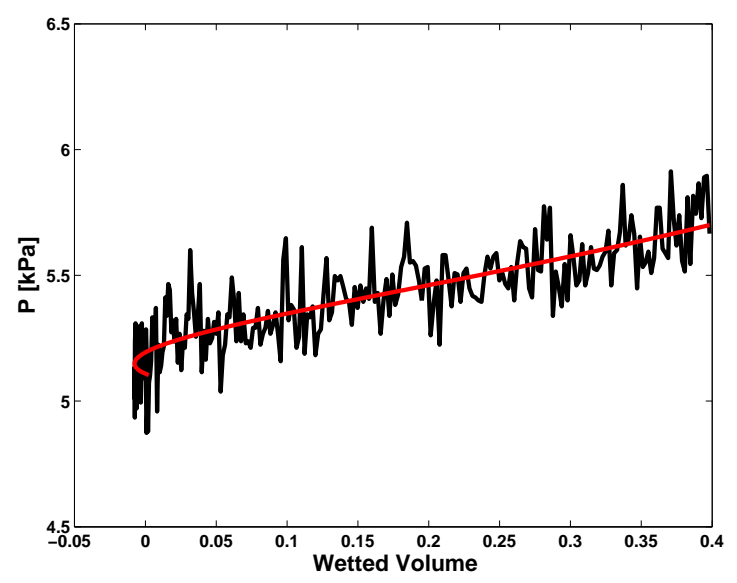

(a) Test at $41.37 \mathrm{kPa}$.

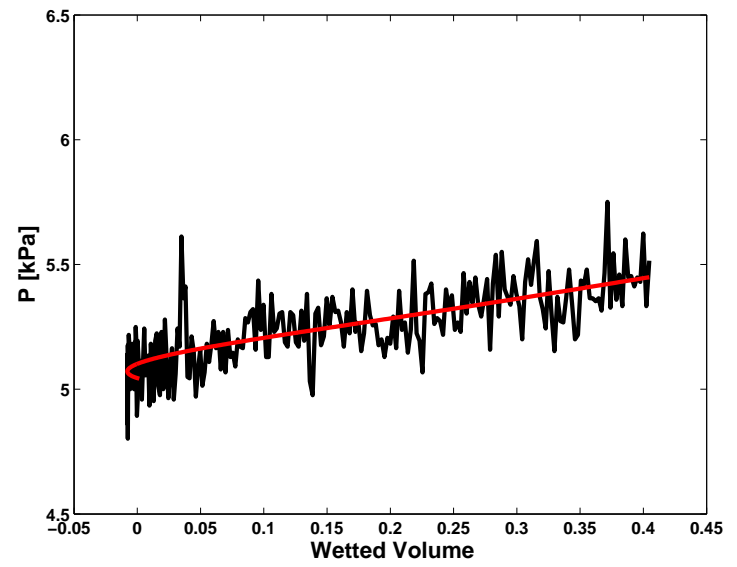

(b) $1^{\text {st }}$ test at $68.95 \mathrm{kPa}$.

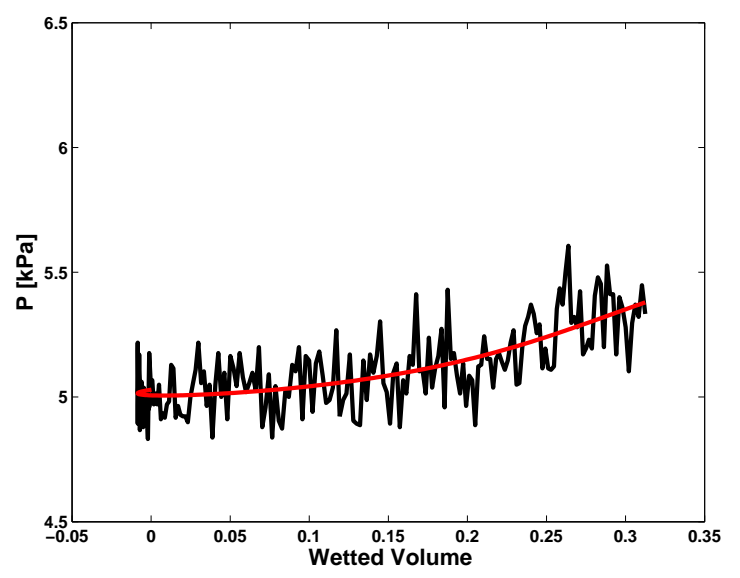

(c) $1^{\text {st }}$ test at $96.53 \mathrm{kPa}$.

Figure I.22. Percolation pressure vs wetted volume for VD436. The tests were conducted at three different compressions on the sample $41.37 \mathrm{kPa}$, $68.95 \mathrm{kPa}, 96.53 \mathrm{kPa}$ while holding the flow rate constant at $9.48 \mathrm{E}$ $4 \mathrm{mLs}^{-1}$. 


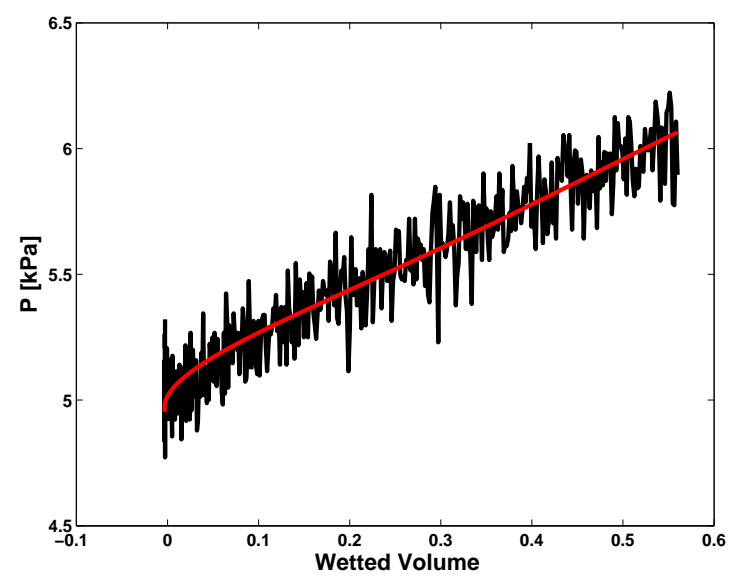

(a) $1^{\text {st }}$ test at $41.37 \mathrm{kPa}$.

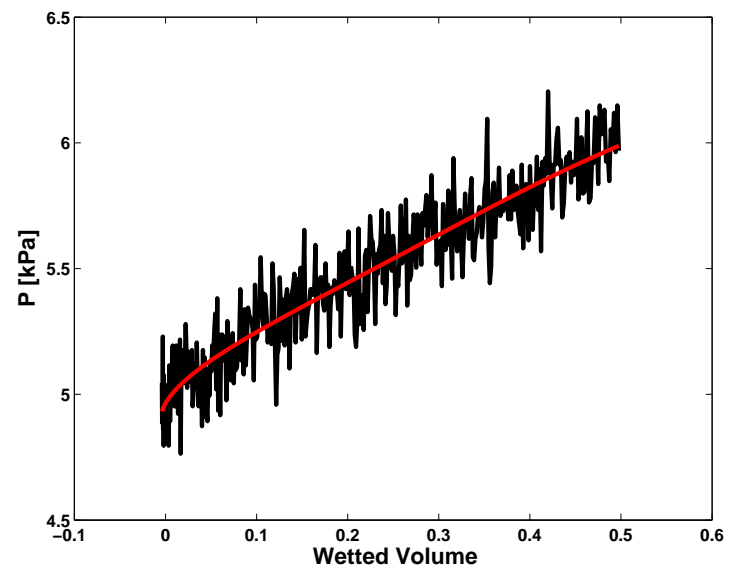

(c) $1^{\text {st }}$ test at $68.95 \mathrm{kPa}$.

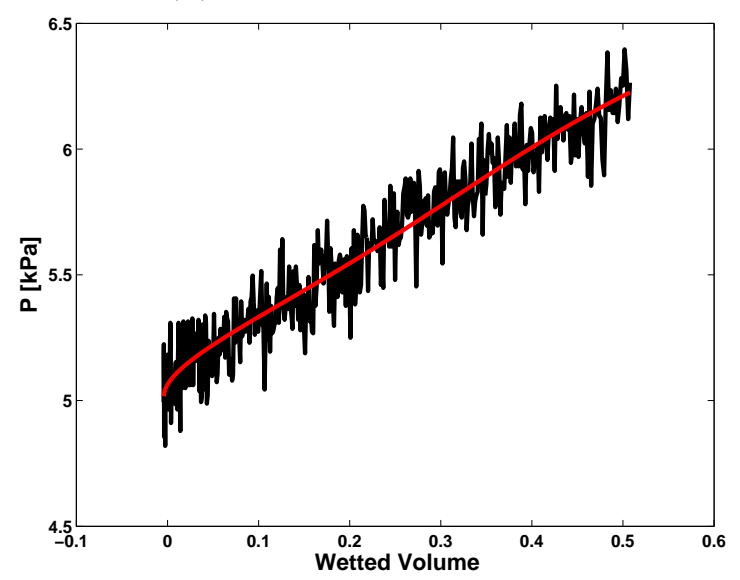

(e) $1^{\text {st }}$ test at $96.53 \mathrm{kPa}$.

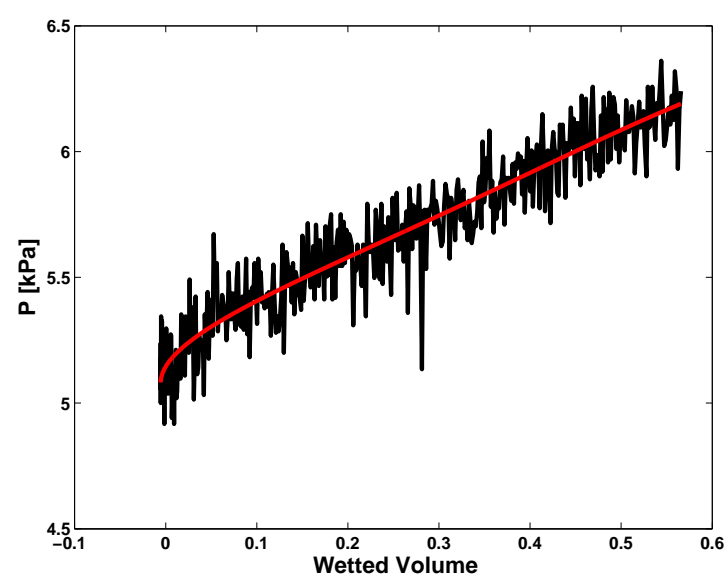

(b) $1^{\text {st }}$ test at $41.37 \mathrm{kPa}$.

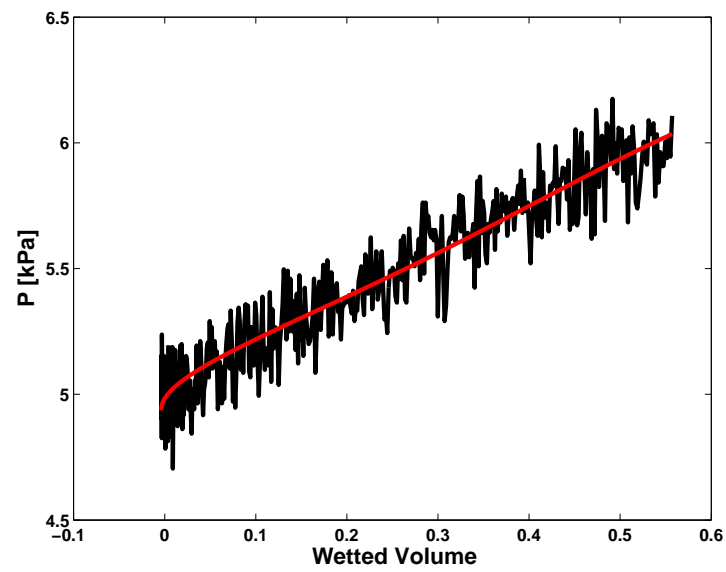

(d) $2^{\text {nd }}$ test at $68.95 \mathrm{kPa}$.

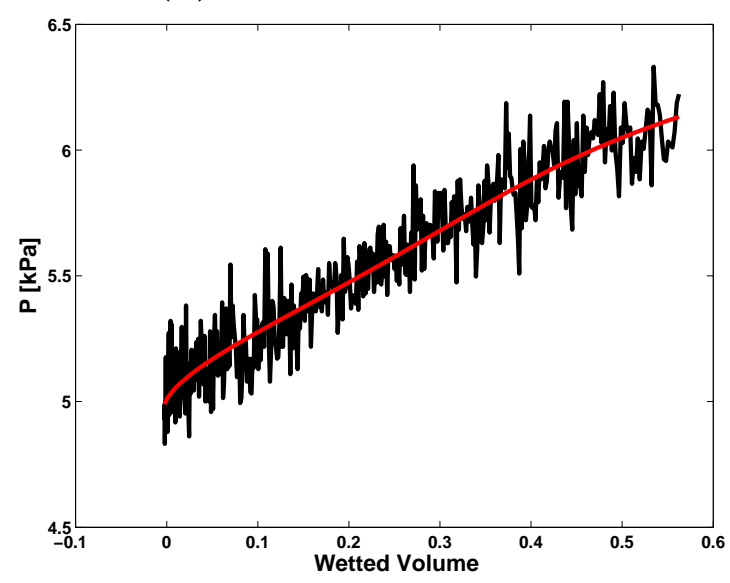

(f) $2^{\text {nd }}$ test at $96.53 \mathrm{kPa}$.

Figure I.23. Percolation pressure vs wetted volume for VD436. The tests were conducted at three different compressions on the sample $41.37 \mathrm{kPa}$, $68.95 \mathrm{kPa}, 96.53 \mathrm{kPa}$ while holding the flow rate constant at $18.75 \mathrm{E}-$ $4 \mathrm{mLs}^{-1}$. 


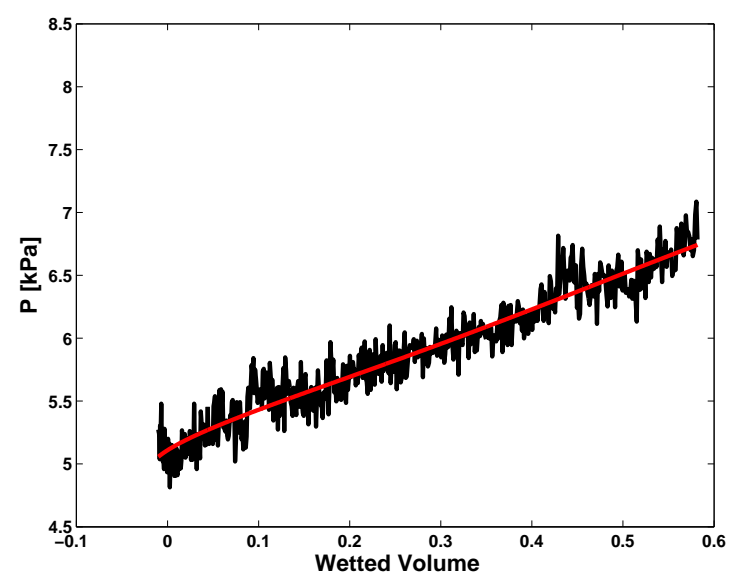

(a) $1^{\text {st }}$ test at $41.37 \mathrm{kPa}$.

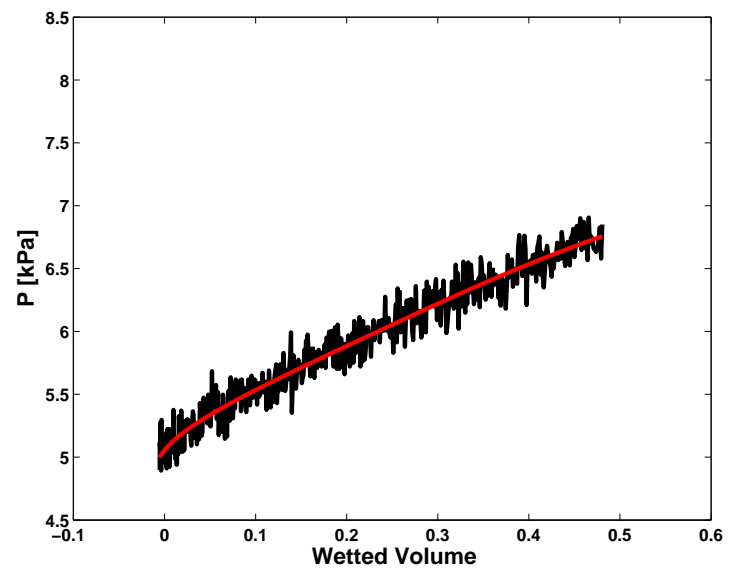

(c) $1^{\text {st }}$ test at $68.95 \mathrm{kPa}$.

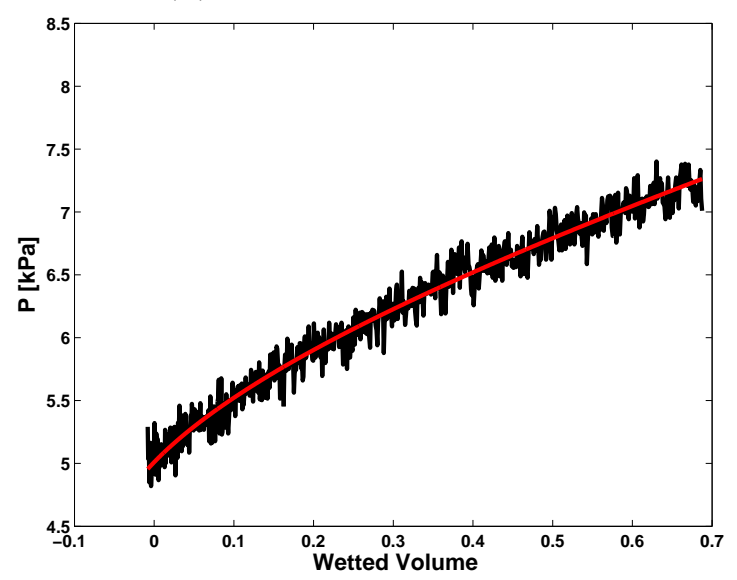

(e) $1^{\text {st }}$ test at $96.53 \mathrm{kPa}$.

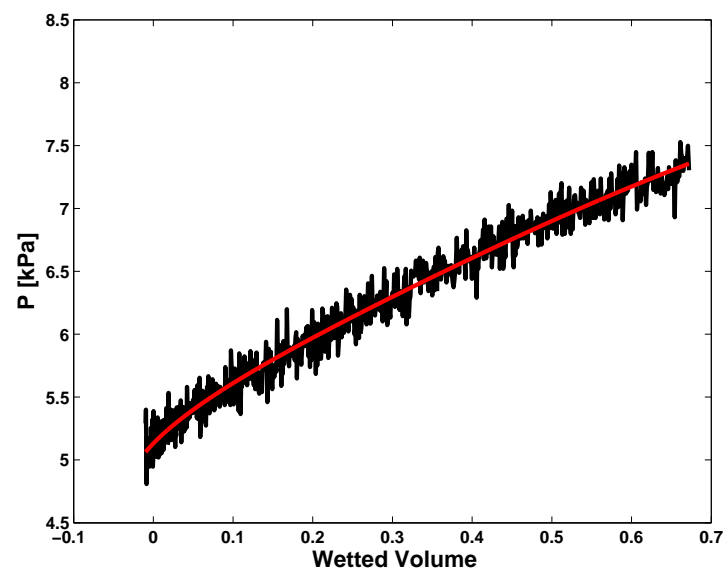

(b) $1^{\text {st }}$ test at $41.37 \mathrm{kPa}$.

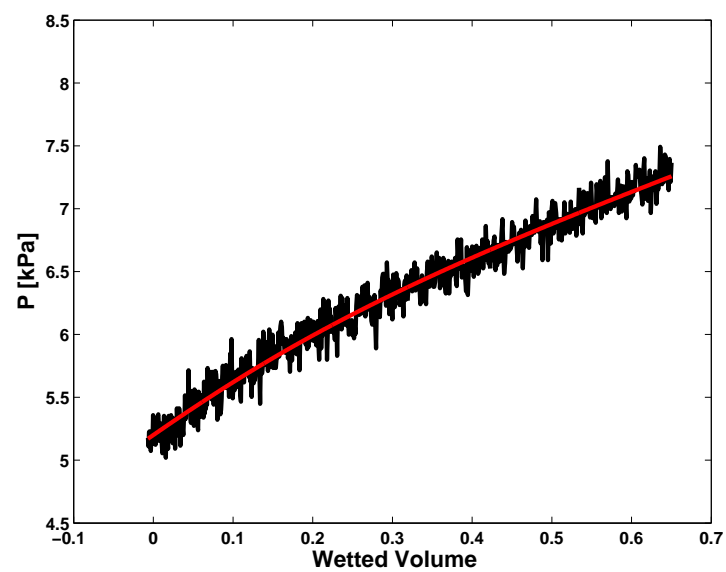

(d) $2^{\text {nd }}$ test at $68.95 \mathrm{kPa}$.

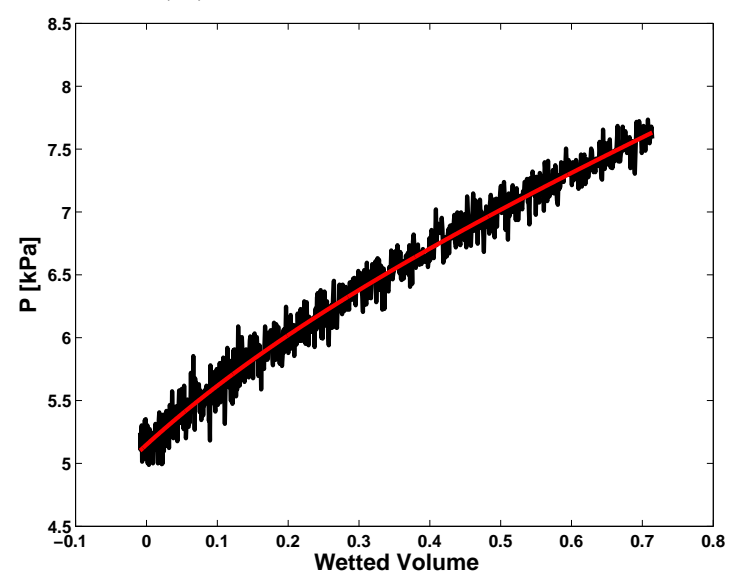

(f) $2^{\text {nd }}$ test at $96.53 \mathrm{kPa}$.

Figure I.24. Percolation pressure vs wetted volume for VD436. The tests were conducted at three different compressions on the sample $41.37 \mathrm{kPa}$, $68.95 \mathrm{kPa}, 96.53 \mathrm{kPa}$ while holding the flow rate constant at $37.08 \mathrm{E}-$ $4 \mathrm{mLs}^{-1}$. 


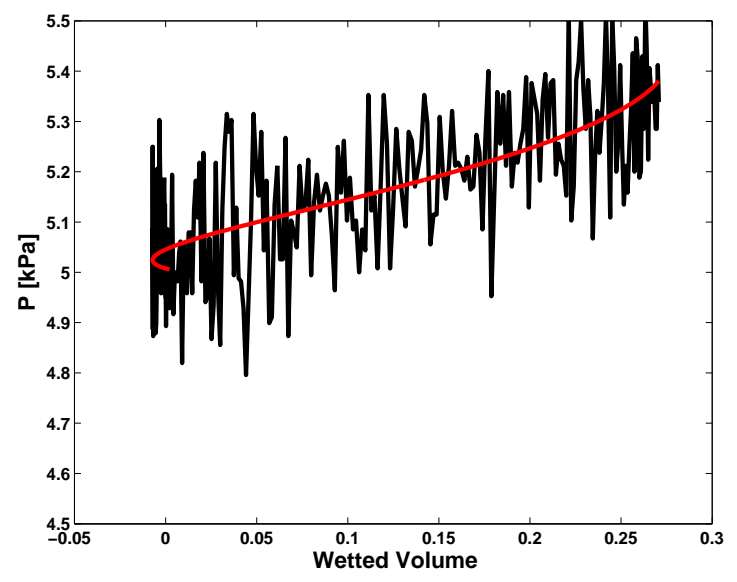

(a) Test at $41.37 \mathrm{kPa}$.

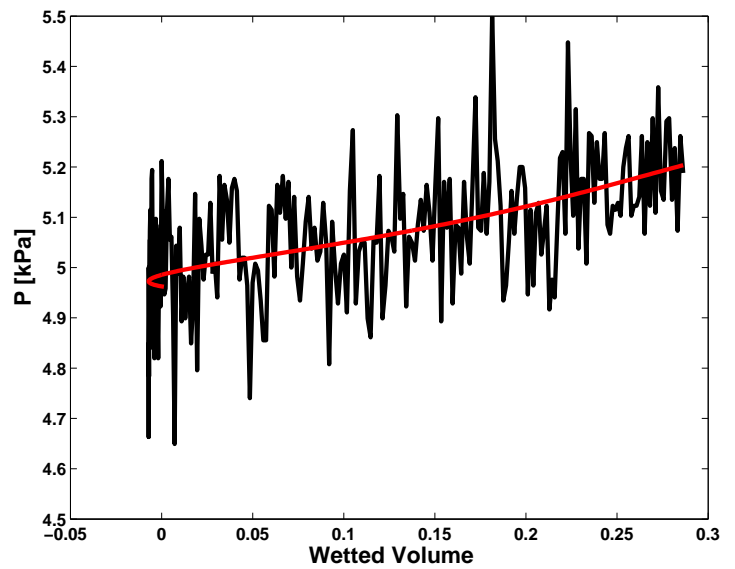

(b) $1^{\text {st }}$ test at $68.95 \mathrm{kPa}$.

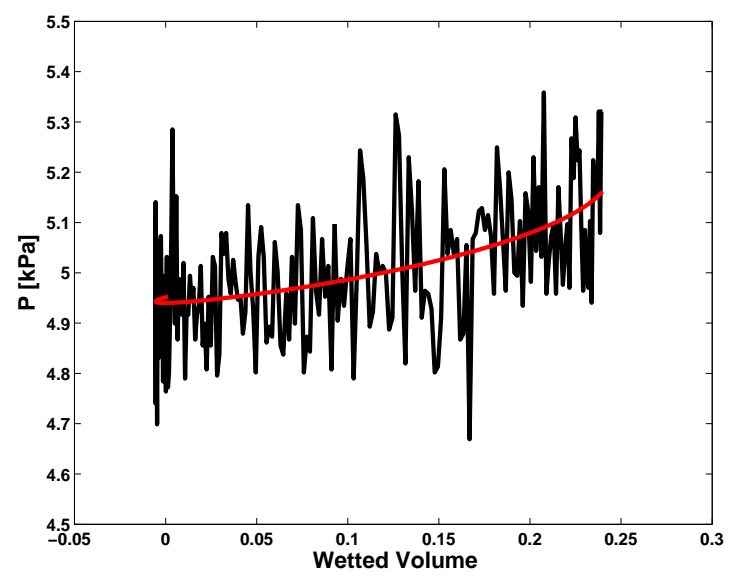

(c) $1^{\text {st }}$ test at $96.53 \mathrm{kPa}$.

Figure I.25. Percolation pressure vs wetted volume for VD328. The tests were conducted at three different compressions on the sample $41.37 \mathrm{kPa}$, $68.95 \mathrm{kPa}, 96.53 \mathrm{kPa}$ while holding the flow rate constant at $9.48 \mathrm{E}$ $4 \mathrm{mLs}^{-1}$. 


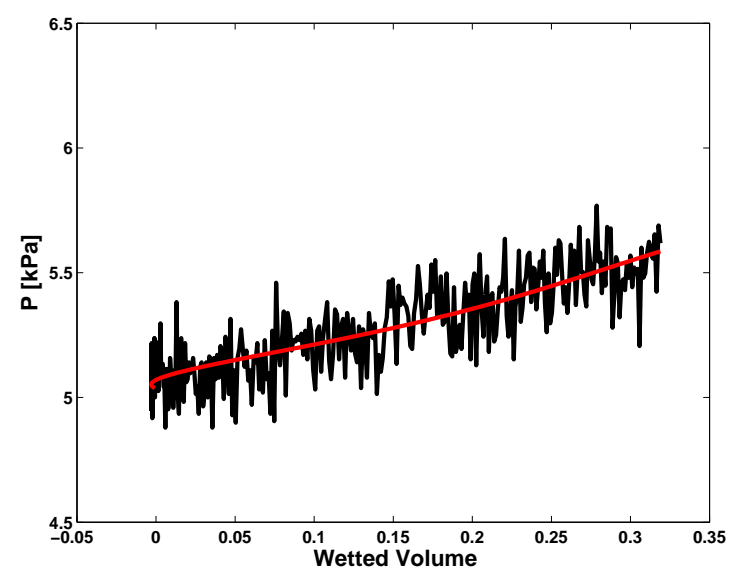

(a) $1^{\text {st }}$ test at $41.37 \mathrm{kPa}$.

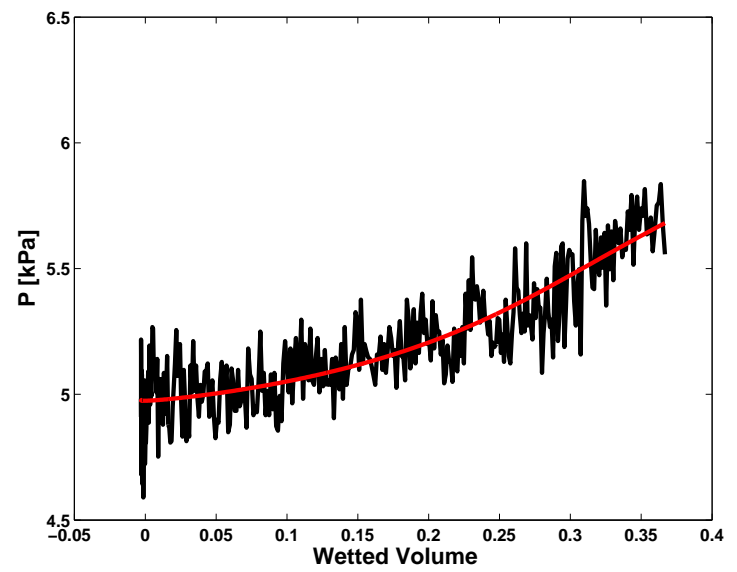

(c) $1^{\text {st }}$ test at $68.95 \mathrm{kPa}$.

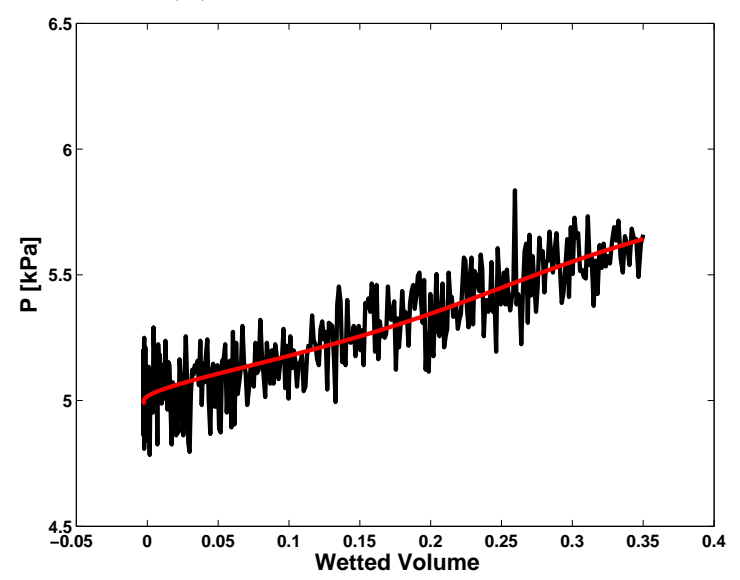

(e) $1^{\text {st }}$ test at $96.53 \mathrm{kPa}$.

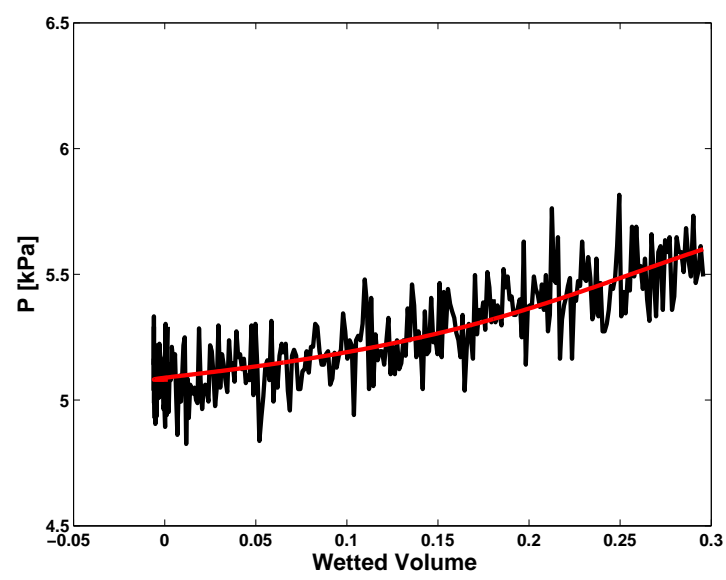

(b) $1^{\text {st }}$ test at $41.37 \mathrm{kPa}$.

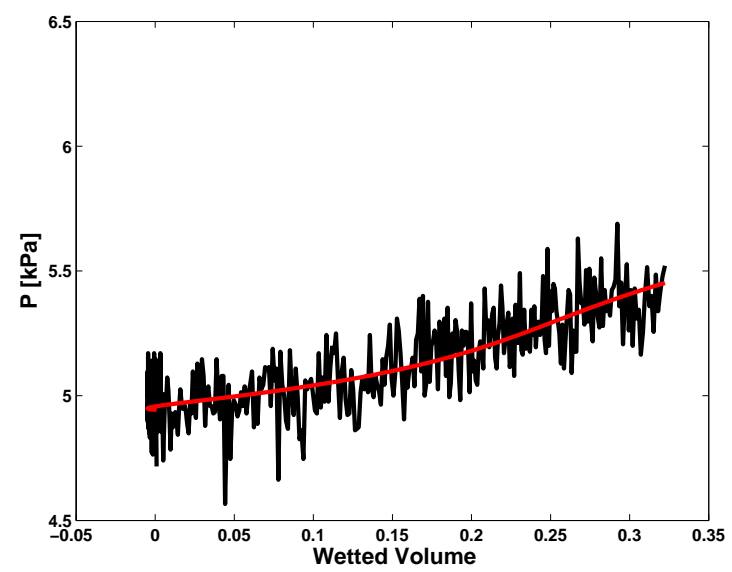

(d) $2^{\text {nd }}$ test at $68.95 \mathrm{kPa}$.

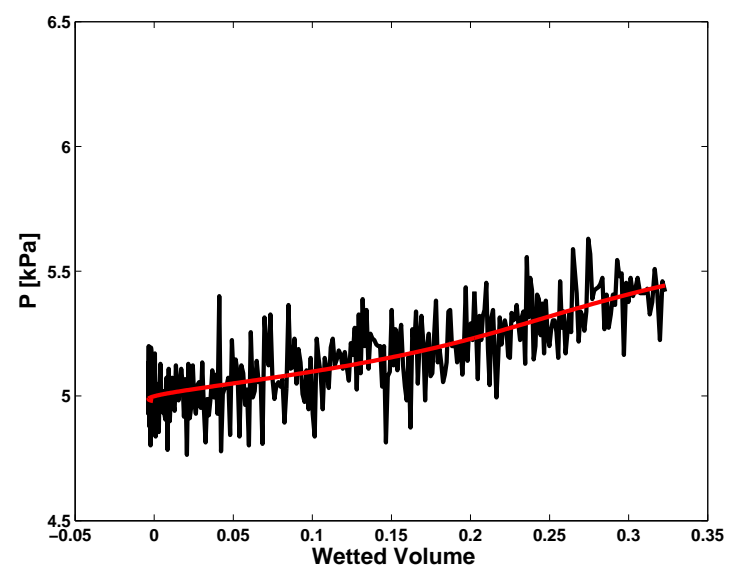

(f) $2^{\text {nd }}$ test at $96.53 \mathrm{kPa}$.

Figure I.26. Percolation pressure vs wetted volume for VD328. The tests were conducted at three different compressions on the sample $41.37 \mathrm{kPa}$, $68.95 \mathrm{kPa}, 96.53 \mathrm{kPa}$ while holding the flow rate constant at $18.75 \mathrm{E}-$ $4 \mathrm{mLs}^{-1}$. 


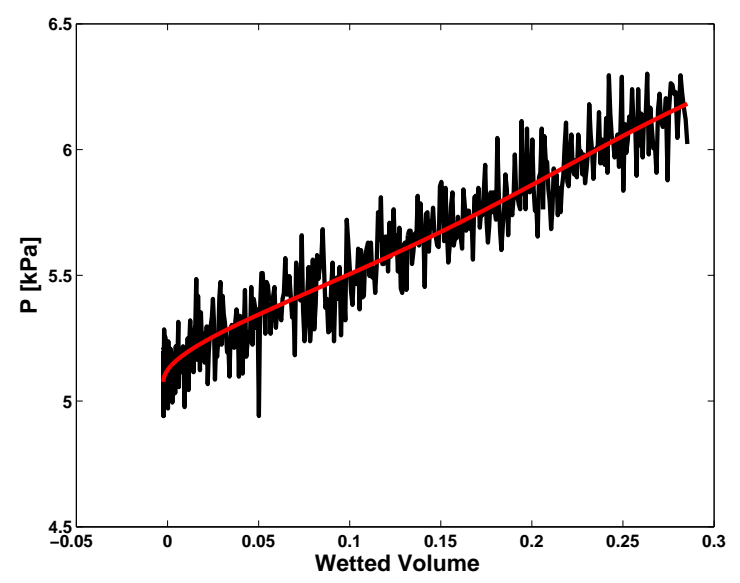

(a) $1^{\text {st }}$ test at $41.37 \mathrm{kPa}$.

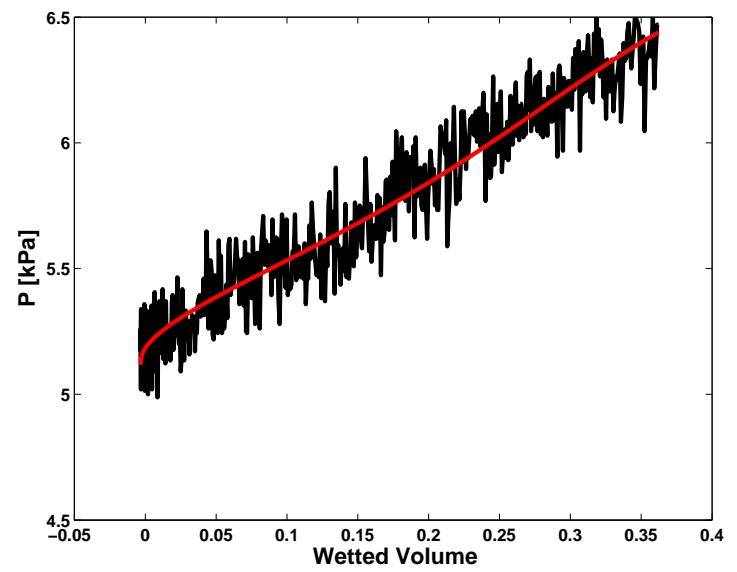

(c) $1^{\text {st }}$ test at $68.95 \mathrm{kPa}$.

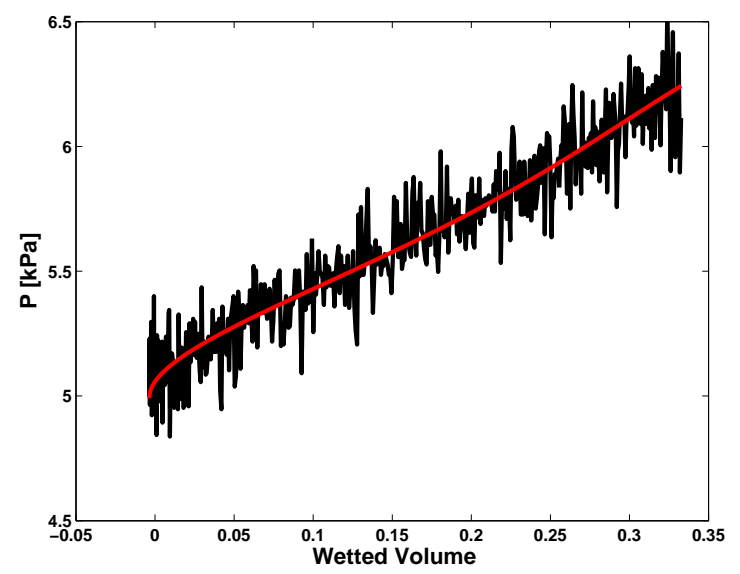

(e) $1^{\text {st }}$ test at $96.53 \mathrm{kPa}$.

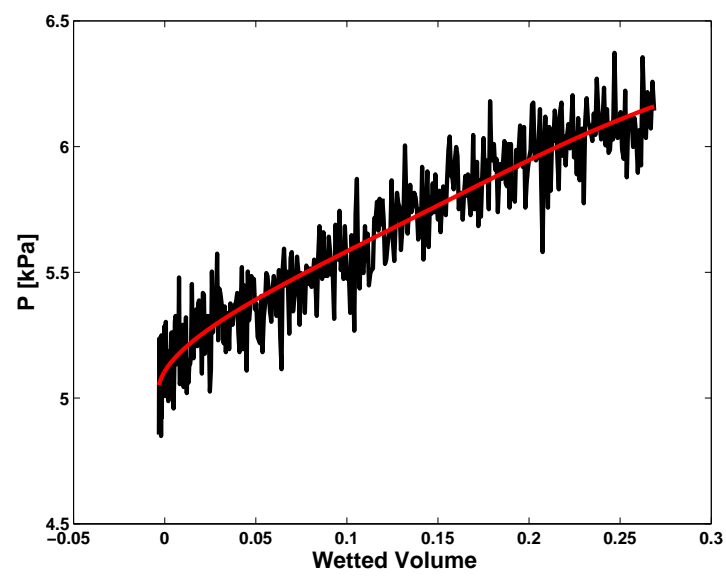

(b) $1^{\text {st }}$ test at $41.37 \mathrm{kPa}$.

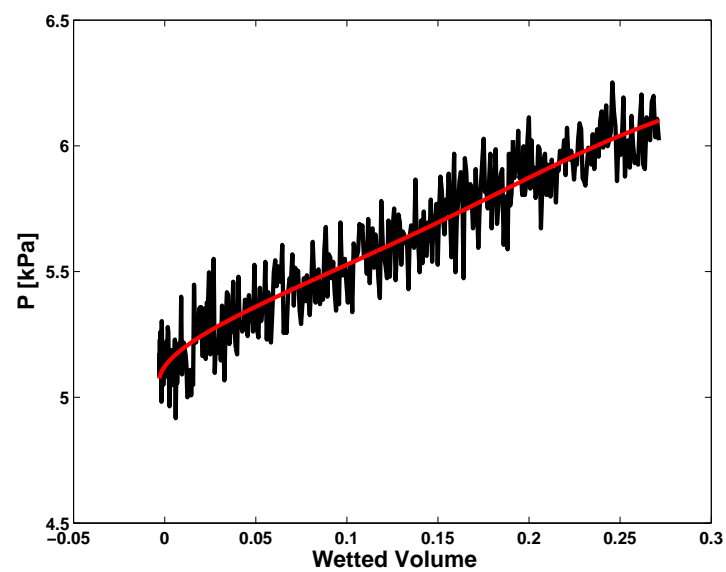

(d) $2^{\text {nd }}$ test at $68.95 \mathrm{kPa}$.

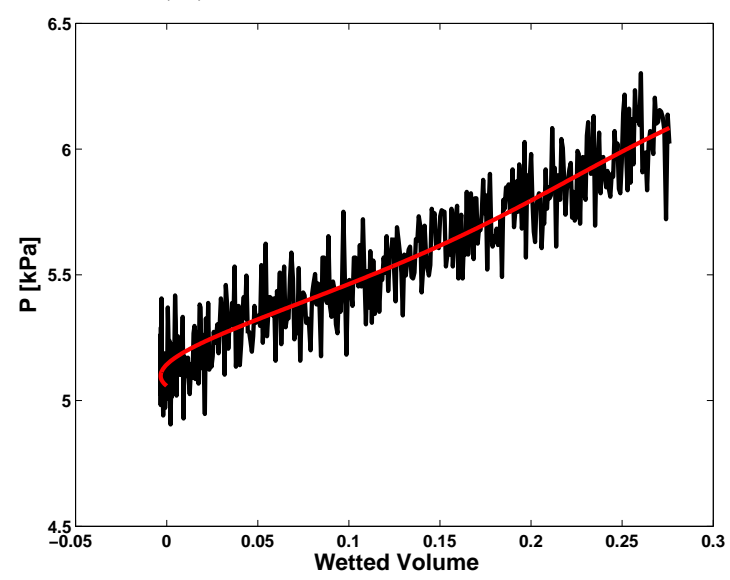

(f) $2^{\text {nd }}$ test at $96.53 \mathrm{kPa}$.

Figure I.27. Percolation pressure vs wetted volume for VD328. The tests were conducted at three different compressions on the sample $41.37 \mathrm{kPa}$, $68.95 \mathrm{kPa}, 96.53 \mathrm{kPa}$ while holding the flow rate constant at $37.08 \mathrm{E}-$ $4 \mathrm{mLs}^{-1}$. 


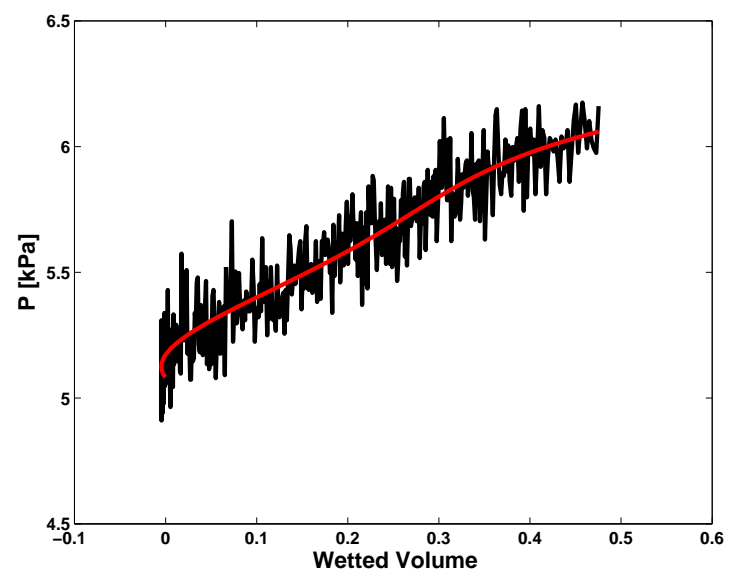

(a) Test at $41.37 \mathrm{kPa}$.

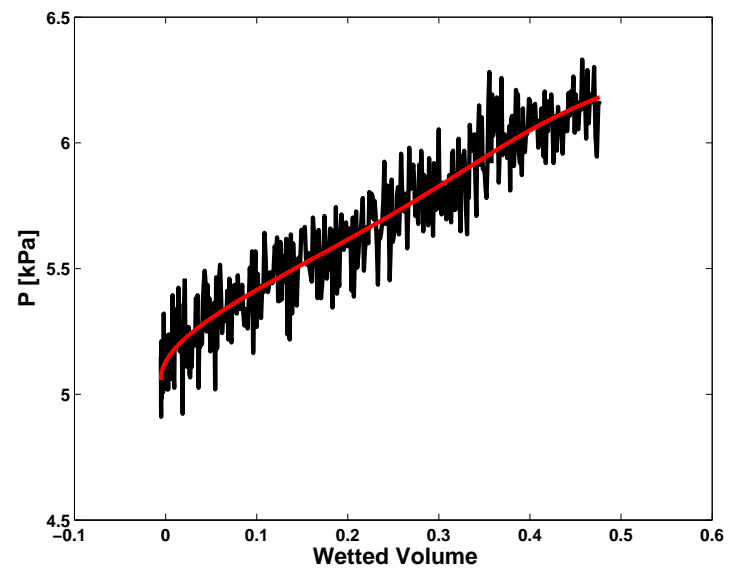

(b) $1^{\text {st }}$ test at $68.95 \mathrm{kPa}$.

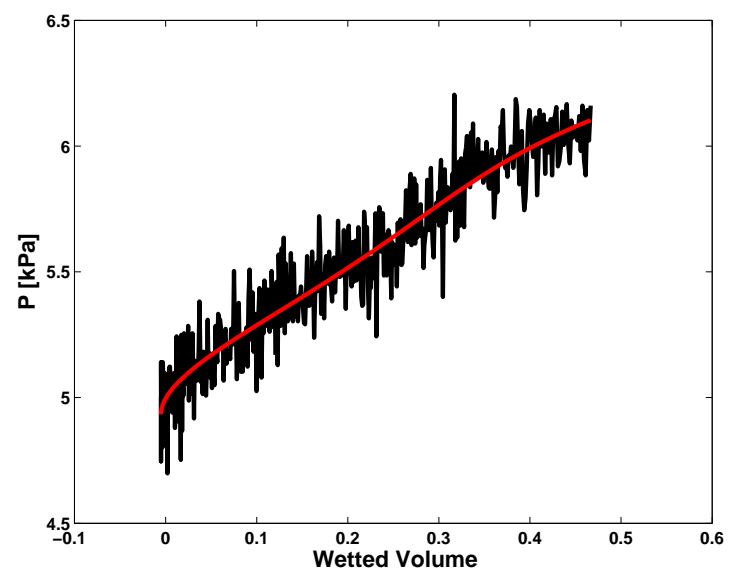

(c) $1^{\text {st }}$ test at $96.53 \mathrm{kPa}$.

Figure I.28. Percolation pressure vs wetted volume for VD302. The tests were conducted at three different compressions on the sample $41.37 \mathrm{kPa}$, $68.95 \mathrm{kPa}, 96.53 \mathrm{kPa}$ while holding the flow rate constant at $9.48 \mathrm{E}$ $4 \mathrm{mLs}^{-1}$. 


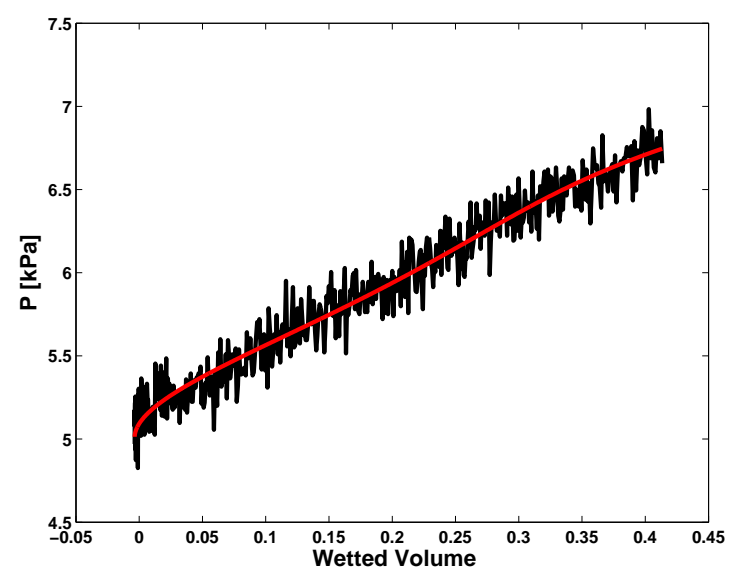

(a) $1^{\text {st }}$ test at $41.37 \mathrm{kPa}$.

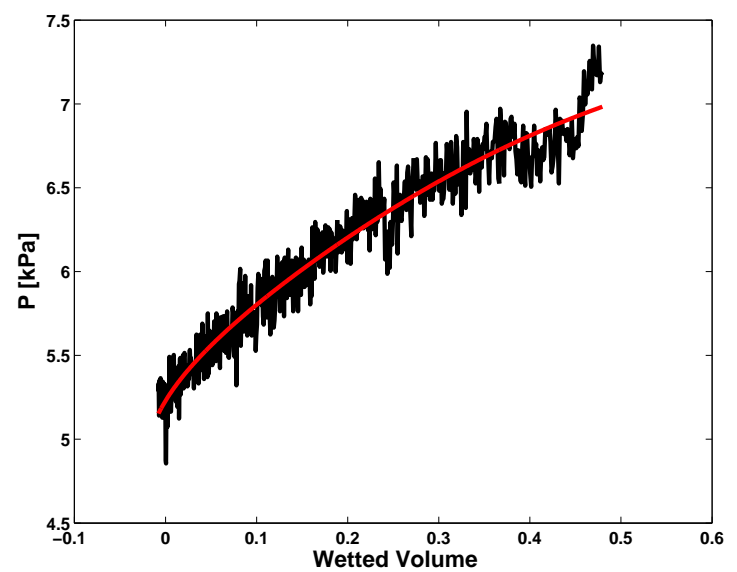

(c) $1^{\text {st }}$ test at $68.95 \mathrm{kPa}$.

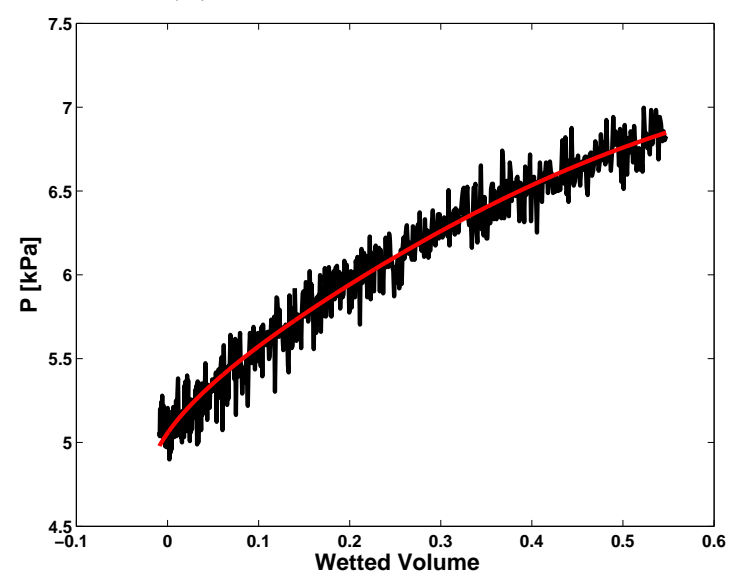

(e) $1^{\text {st }}$ test at $96.53 \mathrm{kPa}$.

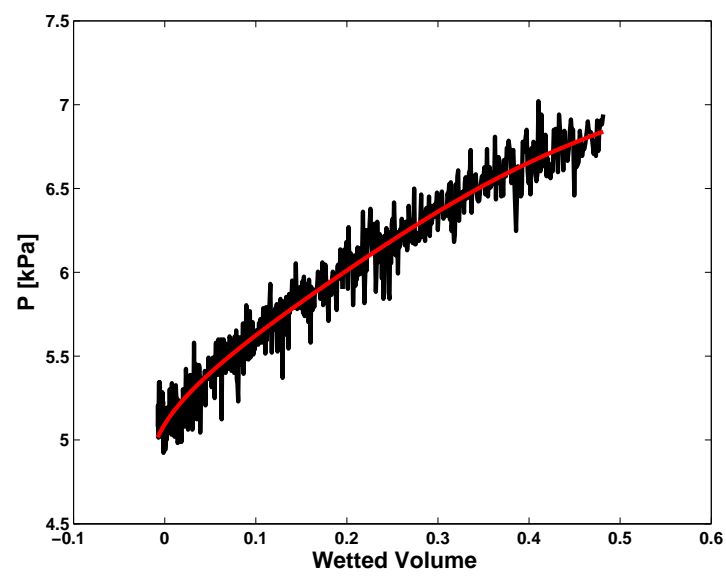

(b) $1^{\text {st }}$ test at $41.37 \mathrm{kPa}$.

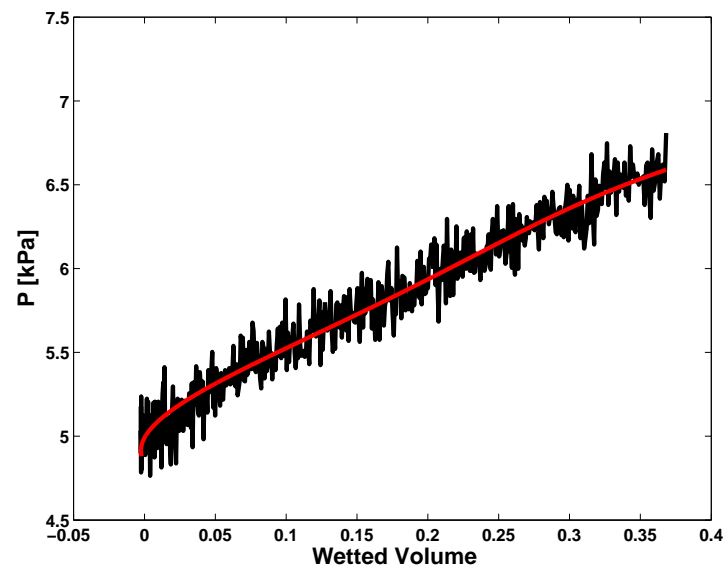

(d) $2^{\text {nd }}$ test at $68.95 \mathrm{kPa}$.

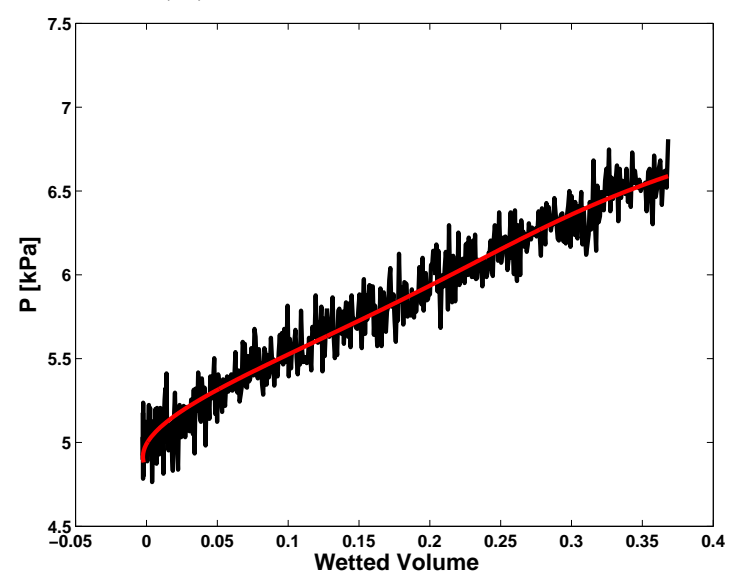

(f) $2^{\text {nd }}$ test at $96.53 \mathrm{kPa}$.

Figure I.29. Percolation pressure vs wetted volume for VD302. The tests were conducted at three different compressions on the sample $41.37 \mathrm{kPa}$, $68.95 \mathrm{kPa}, 96.53 \mathrm{kPa}$ while holding the flow rate constant at $18.75 \mathrm{E}-$ $4 \mathrm{mLs}^{-1}$. 


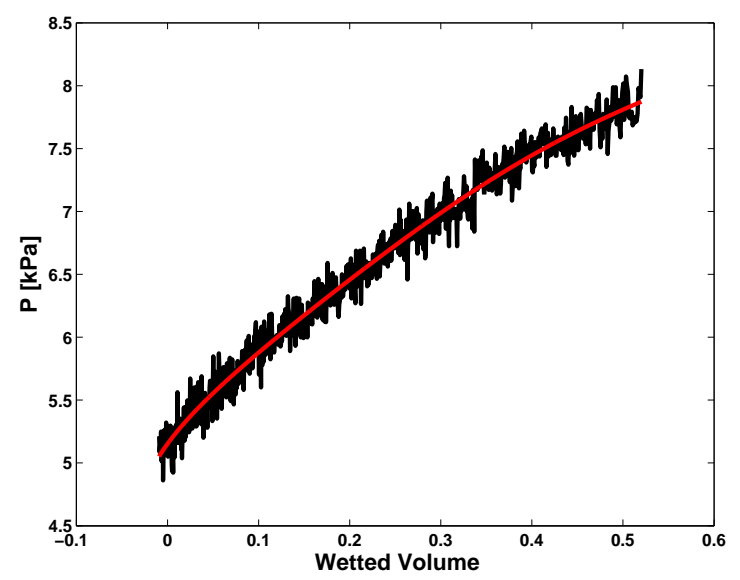

(a) $1^{\text {st }}$ test at $41.37 \mathrm{kPa}$.

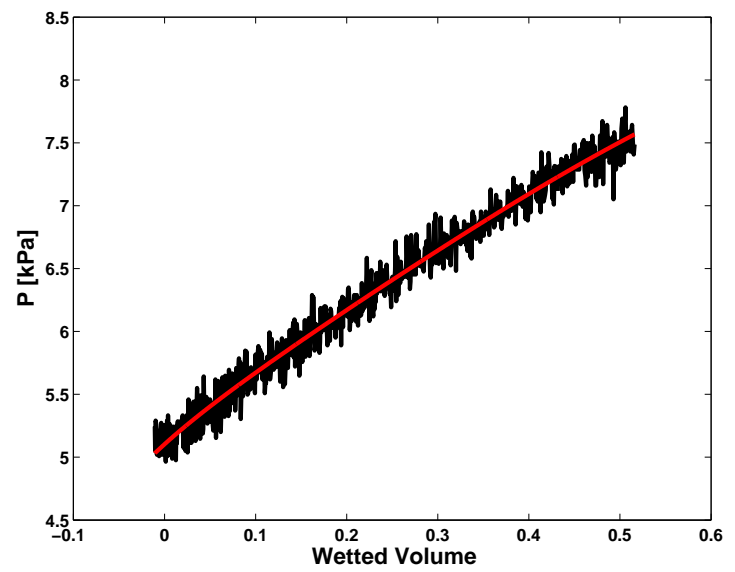

(c) $1^{\text {st }}$ test at $68.95 \mathrm{kPa}$.

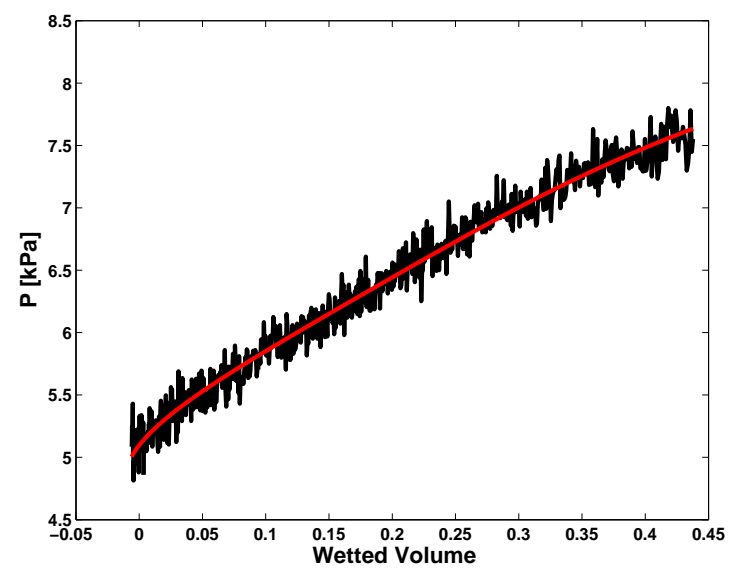

(e) $1^{\text {st }}$ test at $96.53 \mathrm{kPa}$.

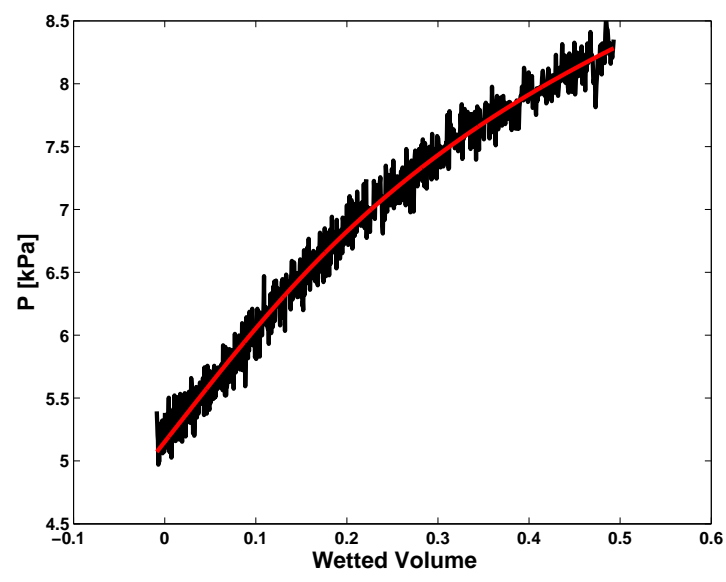

(b) $1^{\text {st }}$ test at $41.37 \mathrm{kPa}$.

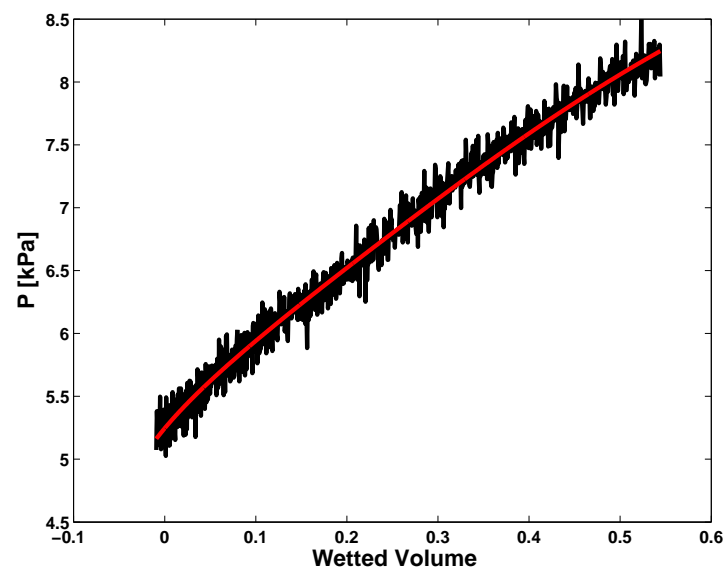

(d) $2^{\text {nd }}$ test at $68.95 \mathrm{kPa}$.

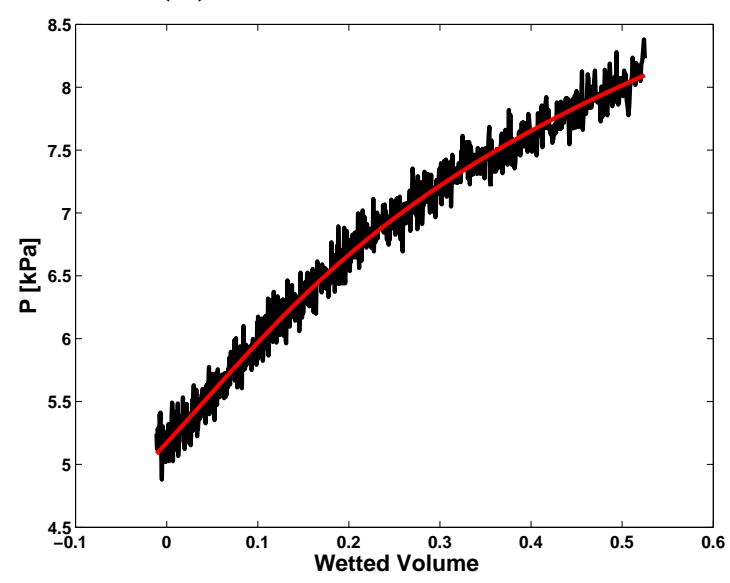

(f) $2^{\text {nd }}$ test at $96.53 \mathrm{kPa}$.

Figure I.30. Percolation pressure vs wetted volume for VD302. The tests were conducted at three different compressions on the sample $41.37 \mathrm{kPa}$, $68.95 \mathrm{kPa}, 96.53 \mathrm{kPa}$ while holding the flow rate constant at $37.08 \mathrm{E}-$ $4 \mathrm{mLs}^{-1}$. 


\section{J. Full CCM PeRmeability Plots}




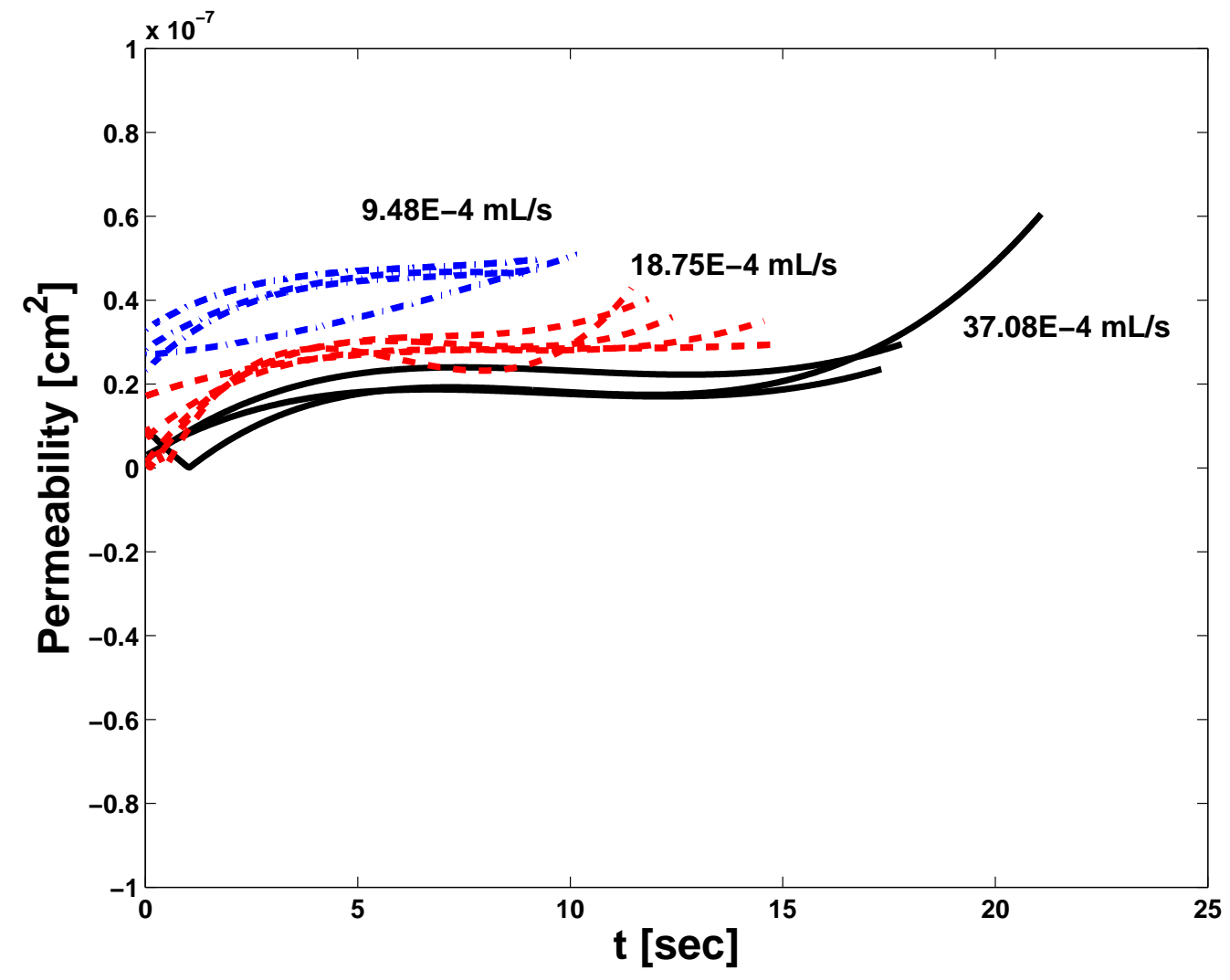

Figure J.1. Permeability for VD420. 


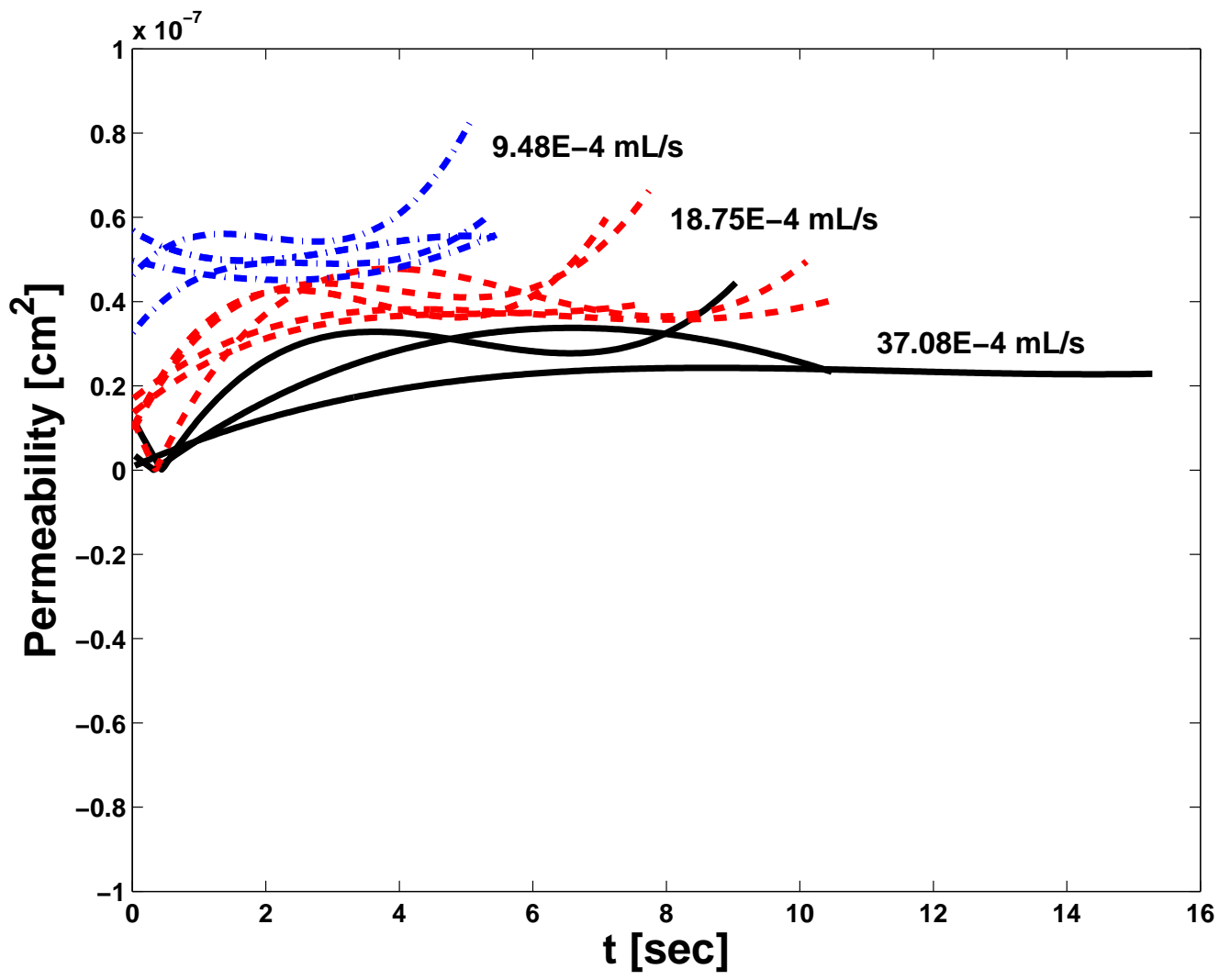

Figure J.2. Permeability for VD421. 


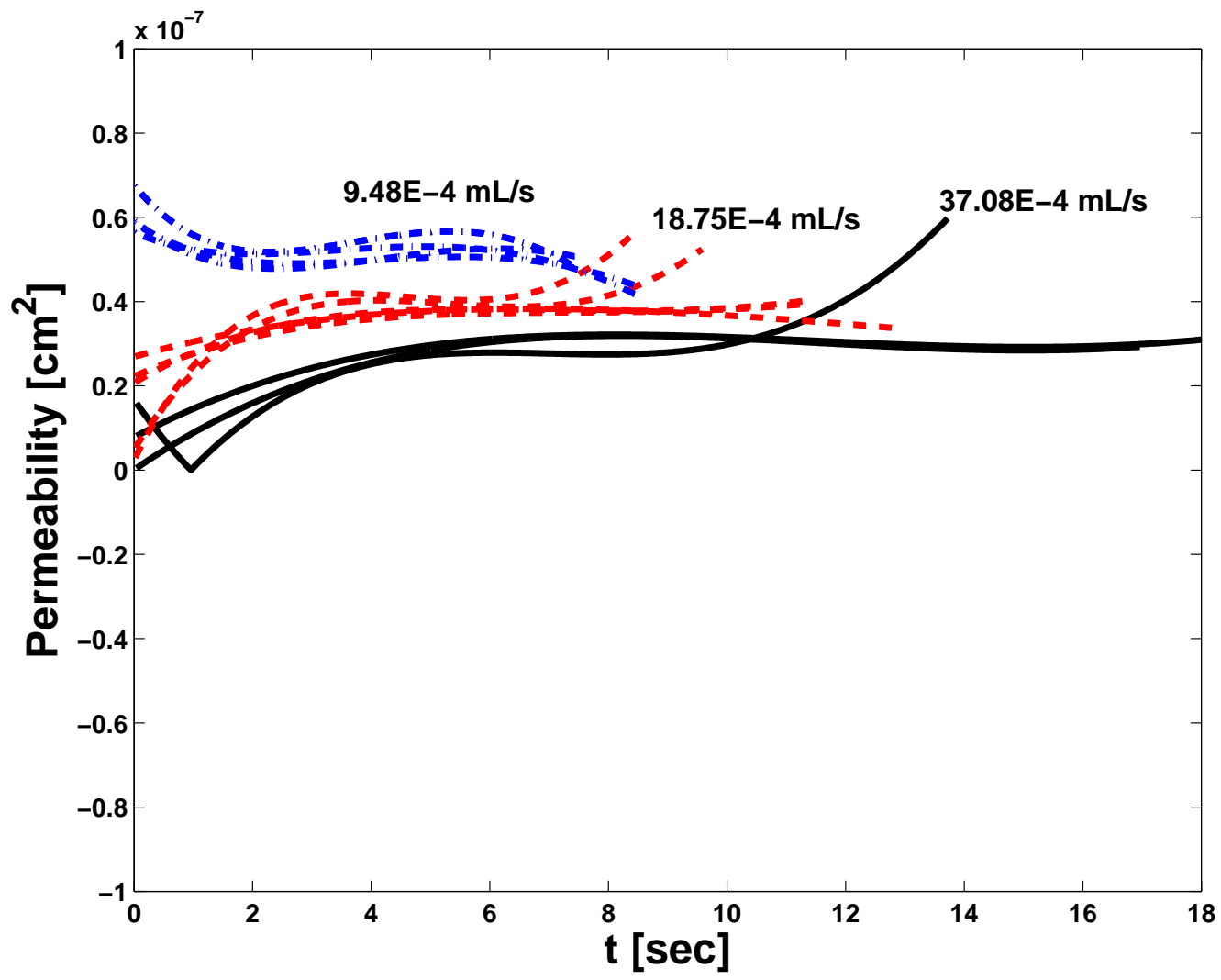

Figure J.3. Permeability for VD423. 


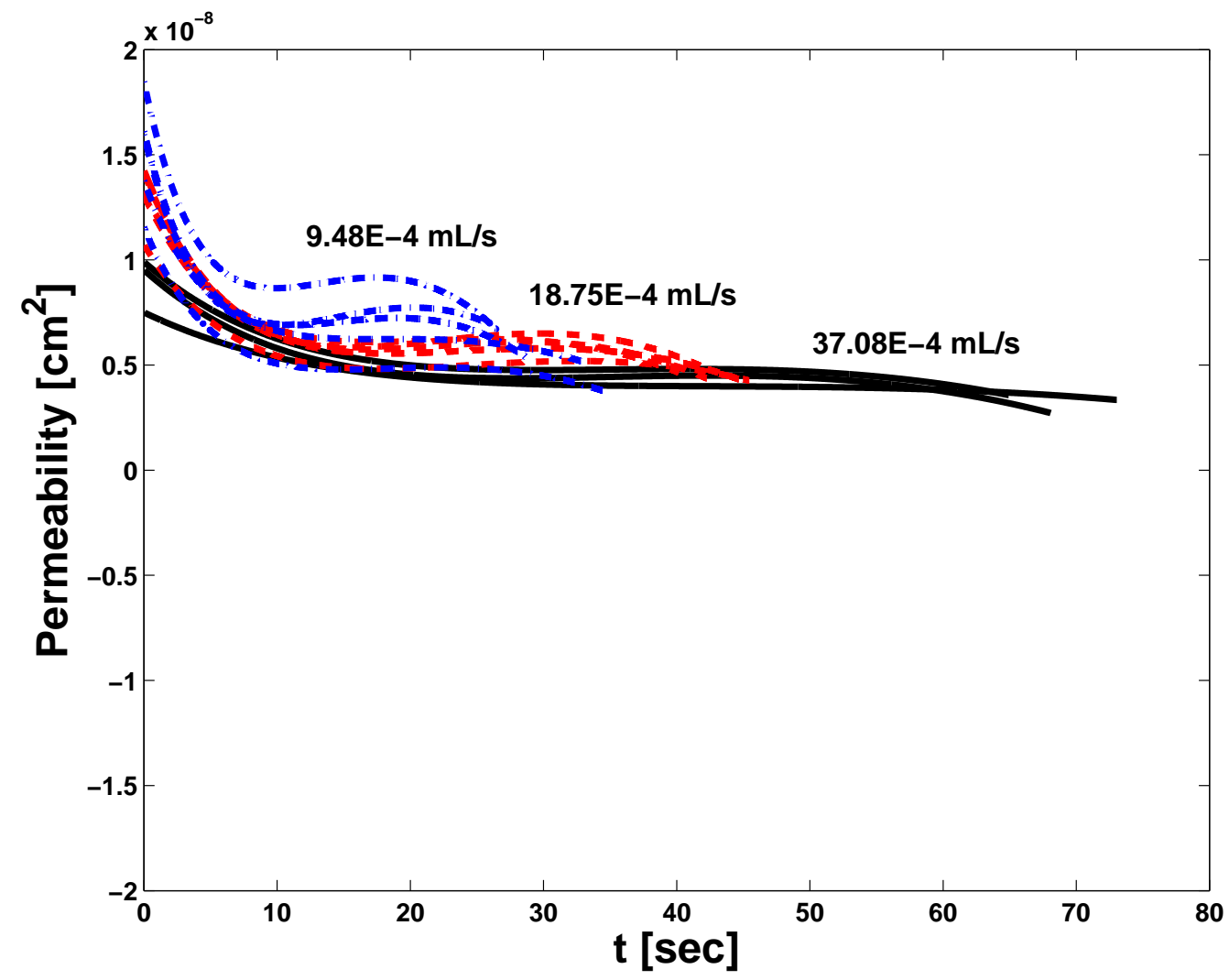

Figure J.4. Permeability for VD422. 


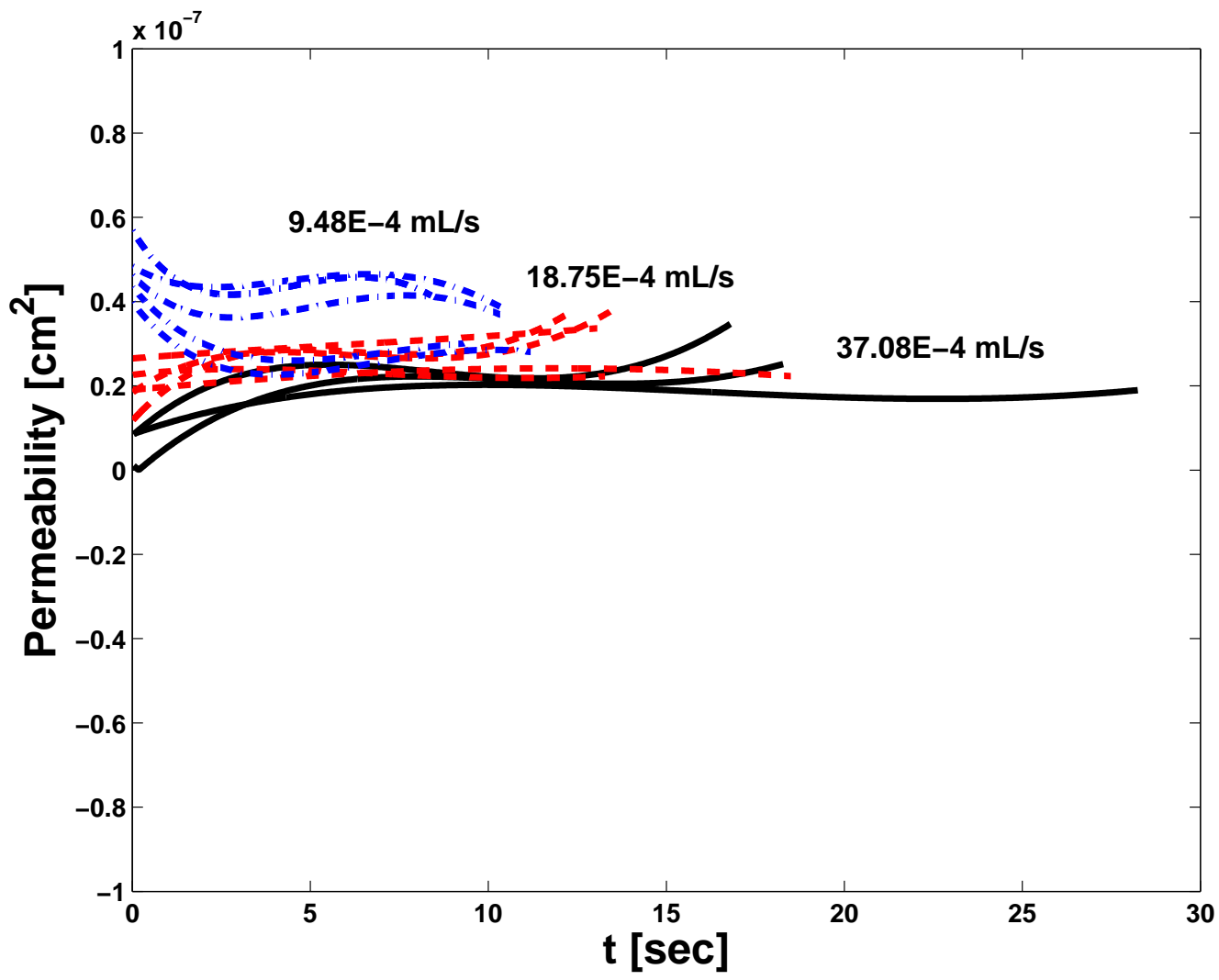

Figure J.5. Permeability for VD424. 


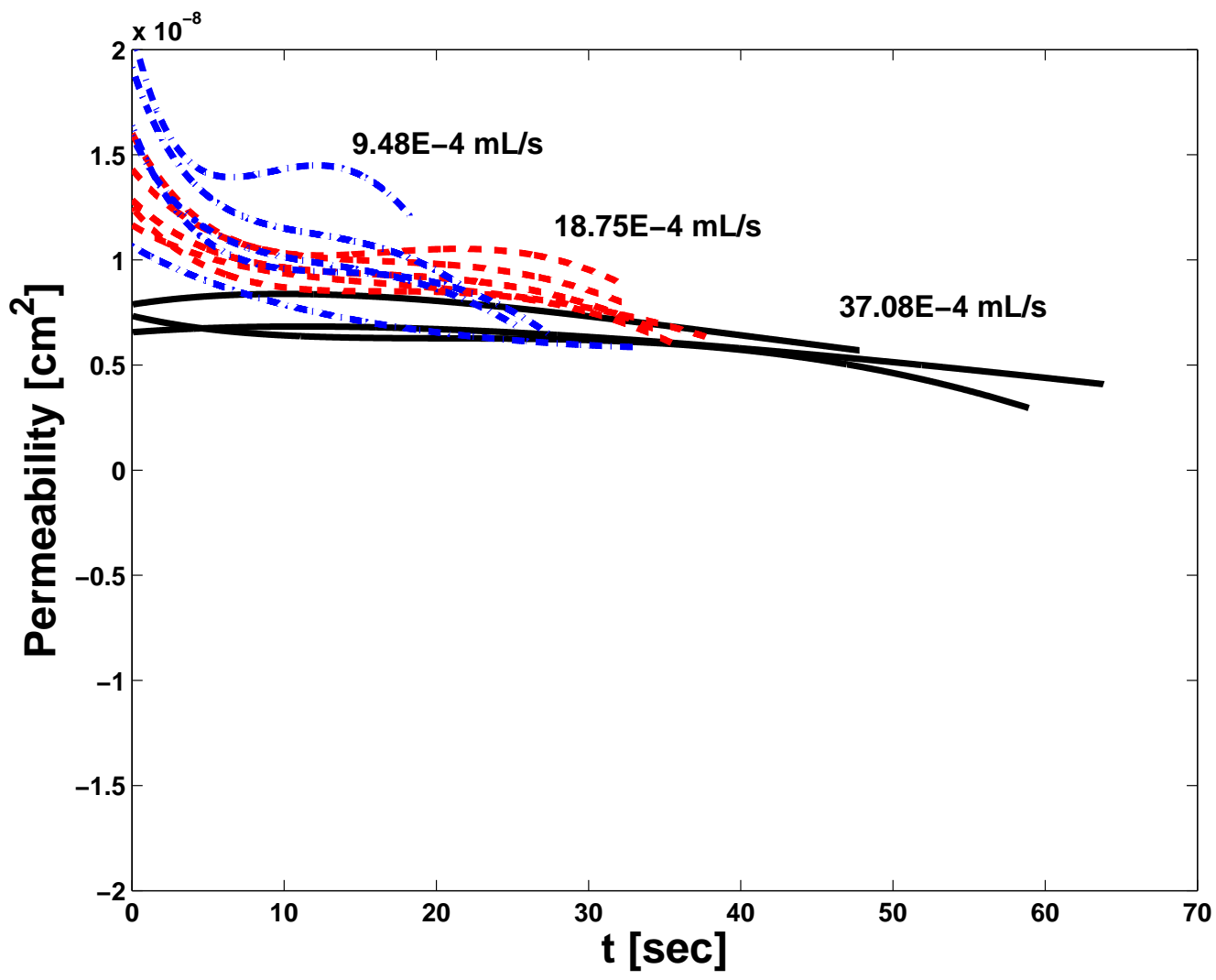

Figure J.6. Permeability for VD425. 


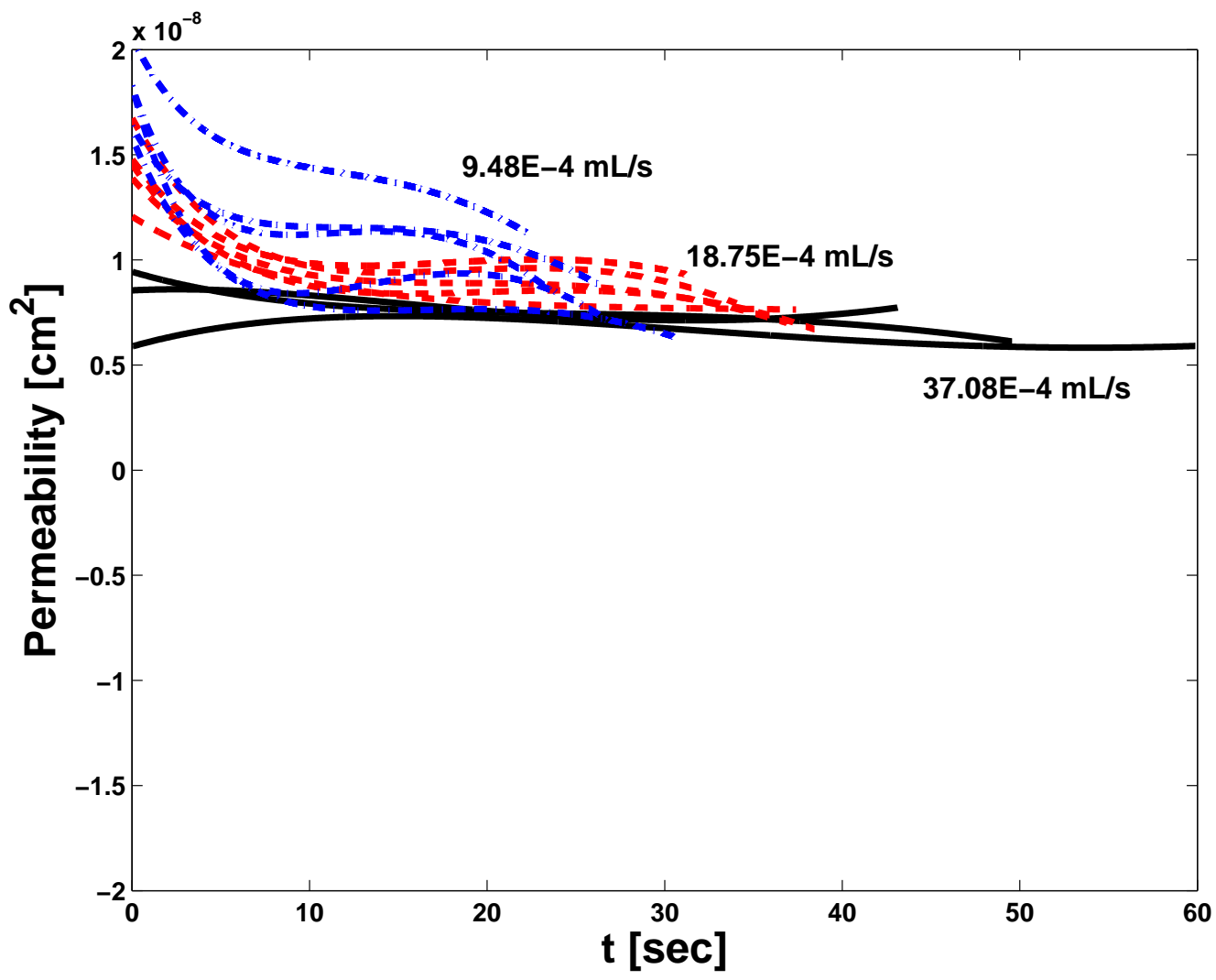

Figure J.7. Permeability for VD432. 


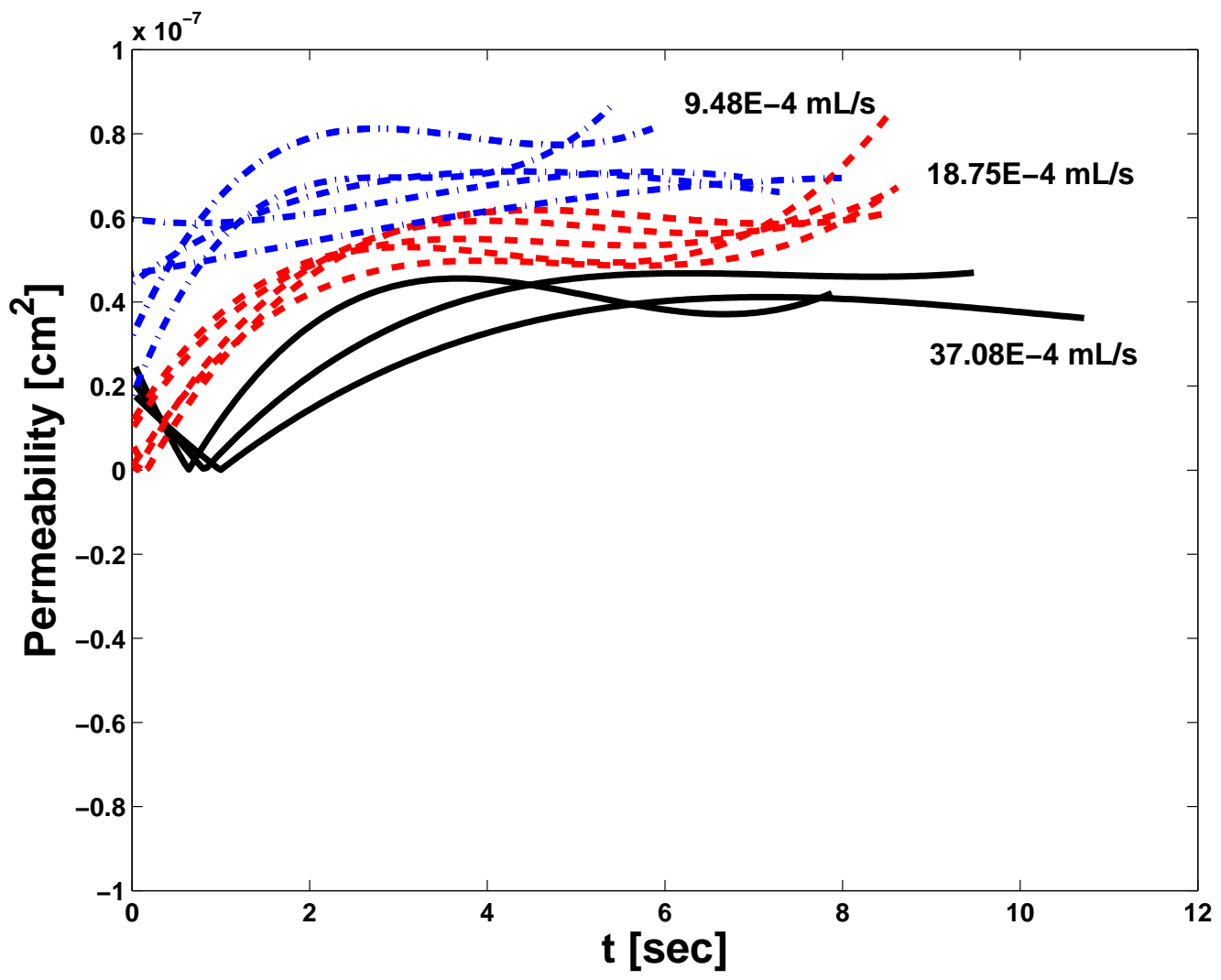

Figure J.8. Permeability for VD436. 


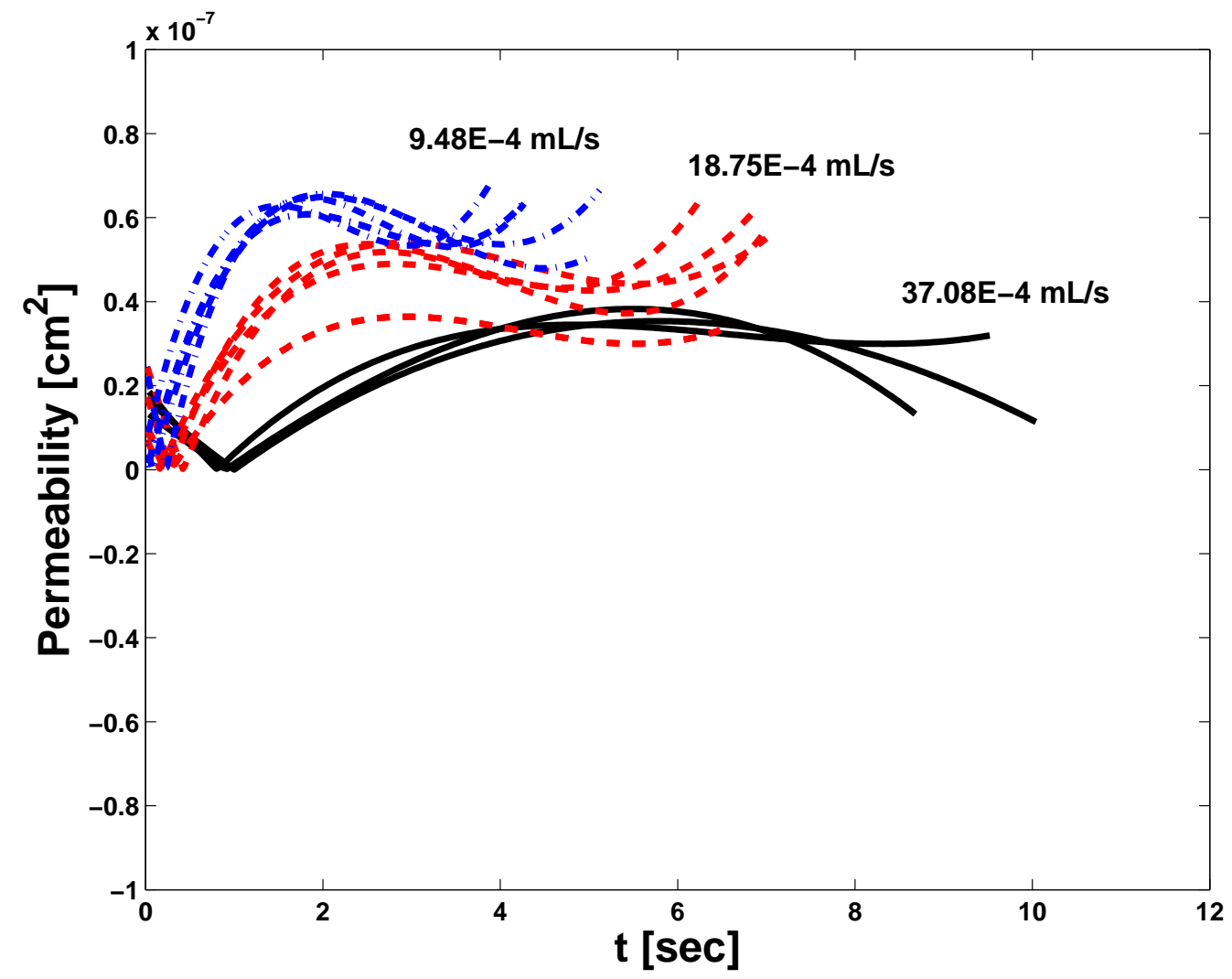

Figure J.9. Permeability for VD328. 


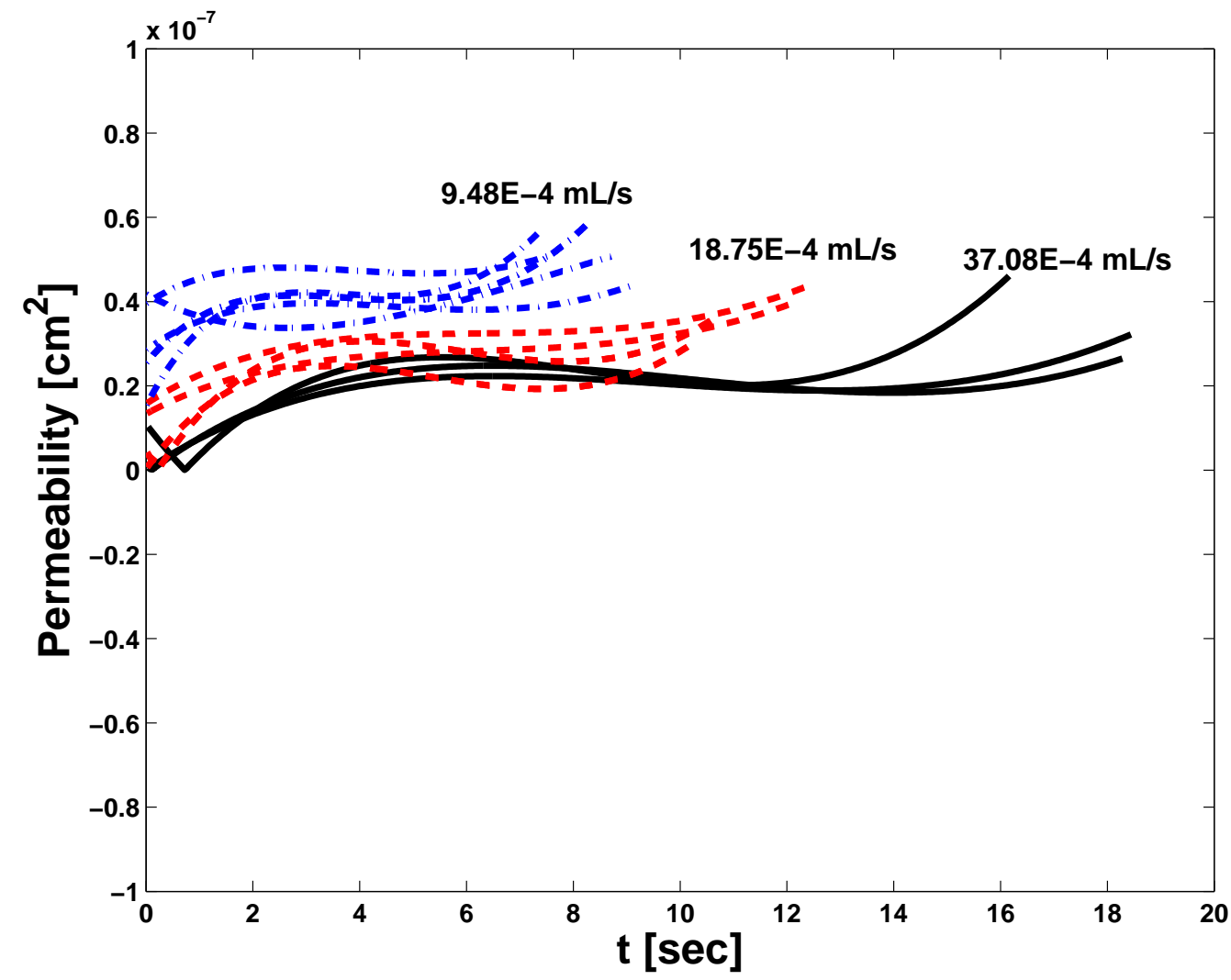

Figure J.10. Permeability for VD302. 


\section{REFERENCES}

[1] Q. Yan, H. Toghiani, and J. Wu. Investigation Of Water Transport Through Membrane In A PEM Fuel Cell By Water Balance Experiments. J. Power Sources, 158:316-325, 2006.

[2] Y. Liu, C. Ji, W. Gu, J. Jorne, and H. A. Gasteiger. Effects Of Catalyst Carbon Support On Proton Conduction And Cathode Performance In PEM Fuel Cells. J. Elec. Society, 158(6):B614-B621, 2011.

[3] M. Eikerling. Water Management In Cathode Catalyst Layers Of PEM Fuel Cells. J. Elec. Society, 153:E58-E70, 2006.

[4] E. F. Medici and J. S. Allen. Existence Of The Phase Drainage Diagram In Protoon Exchange Membrane Fuel Cell Fibrous Diffusion Media. J Power Sources, 191:417-427, 2009.

[5] P. M. Adler and H. Brenner. Multiphase Flow In Porous Media. Ann. Rev. Fluid Mech., 20:35-59, 1988.

[6] D. Wilkinson and J. F. Willemsen. Invasion Peroclation: A New Form Of Percolation Theory. J. Phys. A: Math. Gen, 16:3365-3376, 1983.

[7] G. M. Homsy. Viscous Fingering In Porous Media. Ann. Rev. Fluid Mech., 19: 271-311, 1987.

[8] E. Kierlik, F. Leoni, M. L. Rosinber, and G. Tarjus. Spontaneous Imbibition In A Slit Pore: A Lattice-Gas Dynamic Mean Field Study. Molecular Physics, 109: 1143-1157, 2011.

[9] E. F. Medici and J. S. Allen. Scaling Percolation In Thin Porous Layers. Physics of Fluids, 23:1-9, 2011.

[10] R. Lenormand. Liquids In Porous Media. J Physics-Condenced Matter, 2:SA79SA88, 1990. 
[11] D. L. Fritz. An Implementation Of A Phenomenological Evaporation Model Into A Porous Network Simulaiton For Water Management In Low Temperature Fuel Cells. PhD thesis, Michigan Technological University, 2012.

[12] B.R. Munson, D.F. Young, T.H. Okiishi, and W.W. Huebsch. Fundamentals Of Fluid Mechanics, 6th Edition. John Wiley, 2009.

[13] E. Hecht. Optics 4th Edition. Pearson Education Inc., 2002.

[14] 3M. Fluorinert Liquids For Electronics Manufacturing, 2003.

[15] E. F. Medici. Water Transport In Complex, Non-Wetting Porous Layers With Applications To Water Management In Low Temperature Fuel Cells. PhD thesis, Michigan Technological University, 2010.

[16] M. Uchida, Y. Fukuoka, Y. Sugawara, N. Eda, and A. Ohta. Effects Of Microstructure Of Carbon Support In The Catalyst Layer On The Performance Of Polymer-Electrolyte Fuel Cells. J. Elec. Society, 143:2245-2252, 1996.

[17] R. Lenormand, E. Touboul, and C. Zarcone. Numerical Models And Experiments On Immiscible Displacements In Porous Media. J Fluid Mechanics, 189:165-187, 1988.

[18] J. Bear. Dynamics Of Fluids In Porous Media. DoverPublications, 2013. 